\title{
Interface of steel inserts in Al-Si alloy castings
}

ausgeführt zum Zwecke der Erlangung des akademischen Grades eines Doktors der technischen Wissenschaften unter der Leitung von

\section{o. Univ. Prof. Dr. H. Peter Degischer}

E-308

Institut für Werkstoffwissenschaft und Werkstofftechnologie

eingereicht an der Technischen Universität Wien

Fakultät für Maschinenwesen und Betriebswissenschaften

von

Dipl. Ing. Karolina Monika Zimnik

Matr. Nr. 0727741

Steingasse $6 / 8$

A-1030 Wien 
Dla moich kochanych rodziców To my parents 


\section{Acknowledgements}

The present work was carried out at the Institute of Materials Science and Technology of Vienna University of Technology, Austria. The work was part of the nationally funded ALWS (Al-Light Weight Structures) project coordinated by the Leichtmetallkompetenzzentrum (LKR) Ranshofen in Austria.

This research project would not have been possible without the support of many people.

First and foremost, I would like to express my gratitude to my supervisor, Prof. Hans-Peter Degischer, who has supported me throughout my doctoral thesis with his help and guidance. I wish to thank him for his patience, his suggestions and ideas. He was always abundantly helpful and offered invaluable assistance, without him this thesis would not have been written.

Special thanks to W. Fragner and Dr. N. Ulf of LKR Ranshofen for providing the materials and for showing continuous support.

I am grateful to B. Reitinger of RECENDT (Research Center for Non Destructive Testing) Linz in Austria, for the LUS measurements and sharing the literature to understand the problems.

Thanks to Dr. A. Danninger for helping with the pull out tests, as well as her advice and time. I would like to thank H. Knoblich and C. Zaruba for their advice (especially sample preparation) and their assistance in SEM, LOM in the last few years.

S. Zellhofer for his advice on how to use DSC and TMA, and with this, being able to solve all the problems. Big thank you to $M$. Schöbel for his help with diffraction measurements and for improving my knowledge in this field.

Thanks to R. Bitsche; provision of the design of the demo sample and the test samples as well as discussion about the topic. 
In my work I have been blessed with a friendly and cheerful group of colleagues. Big thanks to them for their kind support, collaboration with different tests carried out in this thesis, and also for the motivating and uplifting mood that was kept throughout all working hours. Special thanks to S. Windisch and T. Grünwald for their help and support. It has been pleasure working with each of you.

I owe special, sincere thanks to Dr. M. Schaude for his support, kind words and especially for his help to allow me to finish my PhD.

I would like to thank all my friends for providing memorable experiences throughout this time and for teaching me how important it is to drop my work once in a while. I am grateful for the wonderful friendships, all the good times, and for each of you who became a part of my life.

Big hug to M. Zawieja for his help with the network problems, software's and for his patience and support as a friend.

Finally, to my best friend (sister) A. Kastner, who always cared to help me overcome setbacks and for being there at all times. Thank you for your friendship, love, support and understanding. For making me laugh and smile, for the amazing moments that you brought into life, and for making Vienna my hometown.

Most importantly, I would like to thank my family, especially my parents for providing me with the opportunity to have come to where I am today. Without them, none of this would have been possible. You have always been my biggest fans and I dearly appreciate that. Thank you for supporting me throughout all my studies, your understanding and endless love.

I deeply appreciate each of you for believing in me. 


\section{Kurzfassung}

Aluminiumlegierungen sind heutzutage aufgrund ihrer geringen Dichte und ausgezeichneten mechanischen Eigenschaften sehr wichtige Materialien. AluminiumSilizium-Gußlegierungen werden im Automobilbau, in der Luftfahrt und in vielen Ingenieurbereichen eingesetzt.

Die relativ hohe Schmelztemperatur von Eisenbasislegierungen erlaubt es, dass Eisenkerne verwendet werden, die mit Aluminiumschmelze eingegossen werden. Diese Stahleinsätze werden bei Al-Si-Legierungen durch Kokillenguss, Niederdruck Kokillenguss und Pressgießen eingebettet. Beim Kokillenguss wurden die Stahleinsätze mit zwei verschiedenen Oberflächen der Stahleinsatze (oxidiert und geätzt) verwendet, wobei die Gussform bei Raumtemperatur und bei hoher Temperatur, 700 und $750^{\circ} \mathrm{C}$ eingesetzt wird, um die Legierungen, Al (99.8\%), AlSi7 und AlSi7Mg0.3 zu vergießen. Im Niederdruck-Kokillenguss wurden zylindrische Einsätze in eine stufenförmige Form eingegossen. Um das Potential von StahlAluminium-Verbund-Guss zu demonstrieren, wurde eine Demo-axial Probe der Dissertation R. Bitsche untersucht.

Der lineare Wärmeausdehnungskoeffizient von Eisen ist nahezu die Hälfte jenes von Aluminium $(\Delta \alpha>12 \mathrm{ppm} / \mathrm{K})$. Während des Erstarrungsvorganges schwinden Aluminiumlegierungen um zirka 6 vol.\%. Dadurch, dass die Dehngrenze dieser Legierungen sehr gering ist, tritt um die Stahleinsätze plastische Verformung auf. Die Differenz im Schwindmaß zwischen Eisen und Aluminium liegt bei rund 1\%, die entsprechende lineare Längenänderung übertrifft den elastischen Bereich. Unter der Annahme, dass die Stahleinsätze in der Al-Legierung nach dem Gießen fest eingebettet sind, bewirkt die Schrumpfung bei der Abkühlung unter $275^{\circ} \mathrm{C}$ elastische Spannungen der Al-Legierung um den Einsatz.

Mit Hilfe von Röntgendiffraktion werden innere Spannungen gemessen. Druckspannungen in der Aluminiummatrix in der Größenordnung von $75 \pm 25 \mathrm{MPa}$ stammen vom Abschrecken der Al Matrix im eutektischen Umfeld ohne Stahleinsatz. Nahe den Einsätzen erhöhen sich die Tangentialspannungen um ca. 100MPa. 
Raster- Elektronen Mikroskopie und Licht Mikroskopie werden zur Gefügecharakterisierung der Proben, insbesondere des Grenzbereiches zwischen Stahl und Aluminium verwendet.

Durch Reaktionen entstehen an den Kontaktstellen zwischen reinem Eisen und reinem Aluminium Al-Fe-Si Phasen. Der Aluminiumguss besteht aus $\alpha$-Dendriten und Al-Si Eutektikum in den interdendritischen Bereichen. Die Erstarrungsstruktur zeigt hohe Kühlraten in den Oberflächenbereichen nahe der Gussform. Dort ist die Größe dieser Dendriten aufgrund der Erstarrung, welche dort beginnt, viel geringer.

Magnesiumzusätze erlauben Auscheidungshärtung des $\alpha$-Aluminiums. Die Dehngrenze von Aluminium bei Raumtemperatur liegt bei 50MPa, jene von AISi12 bei 150MPa und nach Ausscheidungshärtung durch $\mathrm{Mg}_{2} \mathrm{Si}$ bei über 200MPa. Die Haftung der Stahleinsätze ist in der Al-Si Legierung, welche $\mathrm{Mg}$ enthält, erhöht. Eine Schrumpfungsverformung von $0.3 \%$ des Gussteils ergibt eine lokal unterschiedliche plastische Verformung der Bestandteile des Gussgefüges.

In metallografischen Schliffen werden Bindungsfehler zwischen Einlegeteil und Guss sichtbar: Gasporen, Schrumpfungs- und Speisungslunker, Ablösungen und Risse. Durch Laser induzierte Ultraschallmessungen konnten größere Bindungsfehler zwischen dem Stahleinsatz und dem Al-Demo-Guss identifiziert werden.

Neben der Geometrie und der Oberflachenqualität des Stahleinsatzes prägen die Erstarrungsbedingungen die Qualität der Einbettung in einer Al-Gusslegierung. Die Erstarrung sollte entlang des Einlegeteiles beginnen und nicht wieder aufgeschmolzen werden. Für ausreichende Speisung zwischen den Erstarrungsfronten muss gesorgt werden. 


\section{Abstract}

Aluminium alloys are very important materials because of they low density and excellent mechanical properties. Aluminium silicon casting alloys are essential to the automotive, aerospace and engineering sectors. Aluminium silicon alloys are well established for casting processes; however the silicon forms brittle needle-like particles which reduce impact resistance in cast structures. Inserts of steel or cast iron provide locally increased strength and wear resistance.

The relatively high melting temperature of iron base alloys allows placing iron parts into moulds to be surrounded by the liquid Al-melt, which solidifies embedding the insert. Steel inserts are embedded into Al-Si alloys by gravity casting, by low pressure die casting, and by squeeze casting. Oxidized and etched steel rods with different surfaces are used for the gravity casting. For the gravity casting with steel cube inserts, different thermal conditions are used: mould at RT and high temperature with $\mathrm{Al}(99.8 \%)$, AlSi7 and AlSi7Mg0.3. Insert rings of different heights are used for the low pressure die casting of a step shape. A demo-axial sample has been designed in the thesis by Bitsche to demonstrate the potential of embedding a steel insert into aluminium by squeeze casting of AlSi7Mg0.3.

The linear coefficient of thermal expansion (CTE) of Fe is roughly half of that of $\mathrm{Al}$ $(\triangle C T E>12 \mathrm{ppm} / \mathrm{K})$. During solidification, Al-alloys shrink by about 6 vol.\%. The yield strength is so low just below the solidification temperature that plastic deformation will occur around an insert. Assuming that elastic stresses can build up below $275^{\circ} \mathrm{C}$, the remaining misfit volume between $\mathrm{Fe}$ and $\mathrm{Al}$ amounts to about 1 vol.\%. The corresponding linear length change surpasses the elastic range. The elastic stresses building up depend on the yield strength of the Al alloy at service temperature.

Magnesium additions allow precipitation hardening of the $\alpha$-Al. The room temperature yield strength of pure $\mathrm{Al}$ is around $50 \mathrm{MPa}$, that of the AlSi12 eutectic around $150 \mathrm{MPa}$ and after precipitation hardening the alloy by $\mathrm{Mg}_{2} \mathrm{Si}>200 \mathrm{MPa}$. 
Thus a deformation of $0.3 \%$ of the casting causes different degrees of plastic deformation and elastic stresses within the different micro-structural components of the Al alloy around the insert.

The internal stresses in the regions of Al bulk surrounding the insert part are measured by $X$-ray diffraction. The compressive level of $75 \pm 25 \mathrm{MPa}$ in the quenched a-Al Matrix without insert originates from the thermal mismatch with respect to $\mathrm{Si}$. Close to the insert, tangential tensile stresses in Al are identified in the range of $100 \mathrm{MPa}$. The bonding strength increases with the age hardening of the Mgcontaining Al-Si alloy embedding the steel inserts with rough surfaces.

Scanning Electron Microscopy and Light Optical Microscopy are used to characterize the microstructure of the samples, particularly the interface between aluminium and steel. Interface reactions produce Al-Fe-Si phases on chemically cleaned steel but not on naturally oxidized. The Al casting consists of $\alpha$-dendrites and AISi12 eutectic in the interdendritic regions. Close to the mould, the SDA is much smaller, than in the bulk, when solidification started from the mould owing to the higher cooling rate.

Metallography gives evidence of some cracks, gas entrapment and shrinkage holes detected as well non destructively by Laser Ultrasound. Such defects increase when solidification at the interface is delayed. Summarizing, the geometry of the steel insert or surface preparation and particularly the solidification conditions for the embedding Al-alloy have significant consequence on the interface quality, like reaction bonding, gaps or porosity.

Solidification should begin along the interface, where remelting has to be avoided. Sufficient feeding has to be supplied between the solidification fronts. 


\section{Table of contents}

1. Introduction 1

2. State of the art 3

2.1. Aluminium alloys 3

2.1.1. General information about aluminium and aluminium alloys 3

2.1.2. The development of aluminium as a product 5

2.1.3. Classification of aluminium alloys 6

$\begin{array}{lll}\text { 2.1.4. } & \text { Aluminium-silicon cast alloys } & 7\end{array}$

2.2. Strengthening mechanisms 9

2.2.1. Heat treatment of aluminium alloys 9

$\begin{array}{ll}\text { 2.3. Casting process } & 10\end{array}$

$\begin{array}{ll}\text { 2.3.1. } & \text { Gravity die casting } \\ \end{array}$

$\begin{array}{ll}\text { 2.3.2. } & \text { Low pressure die casting }\end{array}$

$\begin{array}{ll}\text { 2.3.3. Squeeze casting } & 13\end{array}$

2.3.4. Microstructure, porosity and shrinkage in Al-cast alloys 15

$\begin{array}{ll}\text { 2.3.5. } & \text { Effect of solidification rate }\end{array}$

$\begin{array}{ll}\text { 2.3.6. Inserts } & 20\end{array}$

$\begin{array}{ll}\text { 2.3.7. } & \text { Objectives of this work }\end{array}$

3. Description of the methodology 22

3.1. Materials 22

3.2. Casting process 26

3.2.1. Gravity die casting - rod sample 26

3.2.2. Gravity die casting - cube sample 30 
$\begin{array}{ll}\text { 3.2.3. Low pressure die casting } & 33\end{array}$

3.2.4. Squeeze casting 34

3.3. Thermal treatments 35

3.4. Test methods 36

3.4.1. Temperature measurements 36

$\begin{array}{ll}\text { 3.4.2. Microstructural analysis } & 37\end{array}$

3.4.3. Hardness 38

3.4.4. Thermal analysis 38

3.4.4.1. Thermal expansion measurements 38

3.4.4.2. Differential Scanning Calorimetry (DSC) 43

3.4.5. Compression test 45

3.4.6. X-ray diffraction analysis $\quad 47$

$\begin{array}{lll}\text { 3.4.7. Pull out test } & 48\end{array}$

3.4.8. Laser Ultrasound 49

4. Results 53

4.1. Temperature measurements on step sample 53

4.2. Metallography 54

4.2.1. Gravity die casting 54

- Rod samples $\quad 54$

- Cube samples 66

$\begin{array}{ll}\text { 4.2.2. Low pressure die casting } & 66\end{array}$

$\begin{array}{ll}\text { 4.2.3. } & \text { Squeeze casting } \\ \end{array}$

4.2.4. Interface gaps, shrinkage pores, dendrites 77

$\begin{array}{ll}\text { 4.2.5. Interface observation } & 81\end{array}$ 
4.2.6. Shrinkage holes around cube insert 94

4.3. Hardness of castings 95

4.4. Thermal analysis 99

$\begin{array}{ll}\text { 4.5. Compression test } & 104\end{array}$

$\begin{array}{ll}\text { 4.6. } & \text { Residual stresses } \\ & 106\end{array}$

$\begin{array}{ll}\text { 4.7. Pull out test } & 109\end{array}$

4.8. Laser Ultrasound measurements on steel-aluminium tube 110

5. Discussion of the results 114

$\begin{array}{ll}\text { 5.1. } & \text { Cast microstructure } \\ \end{array}$

5.2. Dendrite structure in function of cooling rate 118

$\begin{array}{ll}\text { 5.3. } & \text { Embedding strength } \\ & 119\end{array}$

$\begin{array}{ll}\text { 6. Conclusions } & 121\end{array}$

$\begin{array}{ll}\text { 7. References } & 123\end{array}$ 


\section{Chapter 1}

\section{Introduction}

Aluminium is an engineering material with only about century of application, but it has become the world's second most used metal after steel. Aluminium is a key component in many aspects of our life - from the buildings we work in to the cars we drive, from the cans we drink to the flights we take. Its combination of very attractive properties - lightweight, stiff, strong, corrosion resistance, recyclable which make it perfectly fine for an almost endless range of applications and an essential part of modern living and which we use every day of our life. Aluminium is the metal of choice for leading designers, architects and engineers, all of whom are looking for a material which combines functionality with forward looking form and design potential at affordable costs.

Aluminium alloys are grouped according to the major alloying elements they contain. The 4XXX group is mainly alloyed with silicon for ease of casting. Aluminium silicon alloys are well established for casting processes. It is possible to produce reliable castings in complex shapes, in which the minimum mechanical properties obtained in poorly fed sections are higher than in castings made from higher strength but lower castability alloys.

Silicon increases the fluidity of the melt, reduces the melting temperature, decreases the contraction associated with solidification and is very cheap as a raw material. Silicon also has a low density $\left(2.34 \mathrm{~g} \mathrm{~cm}^{-3}\right)$, which may be an advantage in reducing the overall weight of the cast component. Silicon has a very low solubility in aluminium; it segregates in those cast alloys eutectically as virtually pure silicon, which is hard and hence improves the abrasion resistance. The low thermal expansion coefficient is exploited for pistons, the high hardness of the silicon particles for wear resistance. The maximum amount of silicon in cast alloys is of the order of $22-24 \% \mathrm{Si}$, but alloys made by powder metallurgy may go as high as $40-$ $50 \% \mathrm{Si}$. Increasing silicon content increases strength at the expense of ductility, but this effect is not very marked.

Aluminium has about one-third the density and stiffness o steel. It is easily cast, machined and extruded.

Cast inserts are usually made from cast iron or steel. A metal core needs to be placed in a mould parallel to the parting line of the mould to allow for removing before the casting is ejected from the mould cavity. The shape should also provide easy removal from the casting. Cast-in inserts allow for better surface finish and rapid solidification of the casting, which improve the mechanical properties of the process.

The present work discusses the microstructure of Al-alloys, bonding between steel and aluminium casting prepared by different casting processes. The interface was studied using Light Optical Microscopy (LOM) and Scanning Electron Microscopy (SEM). 
The stress analysis has been tried by X-ray and Neutron diffraction. The stresses are determined by the flow behaviour compression test, and the results are described. The aim was to determine in the microstructural influence on the bonding strength.

Chapter 2 describes the state of the art of the cast alloys, as well the general information about aluminium and their applications. Gives the overview of the casting processes with all the defects like pores, shrinkage or cracks, and an effect of solidification rate of the castings.

Description of the methodology describes the geometry of the steel inserts and alloys used for the experimental part, with all the equipments used for the measurements. Chapter 4 presents the results of the work. Measurements results include cast microstructure, hardness value, thermal analysis date, strength and stresses analysis, and laser ultrasound measurements. At the end, discussion of the results and conclusions are shown in Chapter 5 and Chapter 6, respectively. 


\section{Chapter 2}

\section{State of the art}

\subsection{Aluminium alloys}

\subsubsection{General information about aluminium and aluminium alloys}

Aluminium (Al) is the most abundant metallic element in the Earth [1] with its application ranging from transportation and packing to construction, infrastructure and aerospace.

Aluminium and its alloys offer an extremely wide range of capability and applicability, with a unique combination of advantages that make it the material of choice for numerous products and markets. Aluminium takes second in production weight behind steel [2].

The main properties which make aluminium a valuable material are:

- Low density, has only one-third of the mass density of steel

- Good conductor of electricity and heat

- Corrosion resistance, the natural aluminium oxide coating acts as an effective barrier to attack

- Non-magnetic, which makes the material useful in electronic industries

- High reflectivity and therefore finds many decorative uses

- Keeps its toughness down to very low temperatures, without becoming brittle like carbon steels

- No-toxic, which made aluminium of use in food and packing industries

- Malleable, which helps for manufacturing and shaping processes

- Recyclable, offering special secondary alloys.

Due to this unique combination of properties, the variety of applications of aluminium continues to increase [3]. It is essential in our daily lives. We can not fly, go by high speed train, high performance car or fast ferry without it. We can not get heat and light into our homes, offices without it. We depend on it to preserve our food, our medicine and to provide electronic components for our computers.

Aluminium alloys are alloys in which aluminium is the predominant metal. The typical alloying elements are magnesium, copper, manganese, silicon and zinc. The alloying elements are added to bring changes in properties of aluminium.

Aluminium alloys are used in engineering structures and components where light weight and corrosion resistance are required [4]. Al-alloys are used extensively in aircraft due to their strength to weight ratio. 
Table 2.1 Property of pure Al, Mg and Fe

\begin{tabular}{|l|c|c|c|}
\hline Property & Al & Mg & Fe \\
\hline \multicolumn{3}{|c|}{} \\
\hline Density $\left[\mathrm{g} / \mathrm{cm}^{3}\right]$ & 2.7 & 1.74 & 7.87 \\
\hline Melting point $\left[{ }^{\circ} \mathrm{C}\right]$ & 660 & 650 & 1535 \\
\hline Young modulus $[\mathrm{GPa}]$ & 70 & 45 & 210 \\
\hline Brinell hardness $[\mathrm{MPa}]$ & 95 & 150 & 140 \\
\hline Production per annum & $2 \times 10^{7}$ & $5 \times 10^{5}$ & $8 \times 10^{8}$ \\
\hline Relative cost & 3.7 & 7.5 & 1 \\
\hline
\end{tabular}

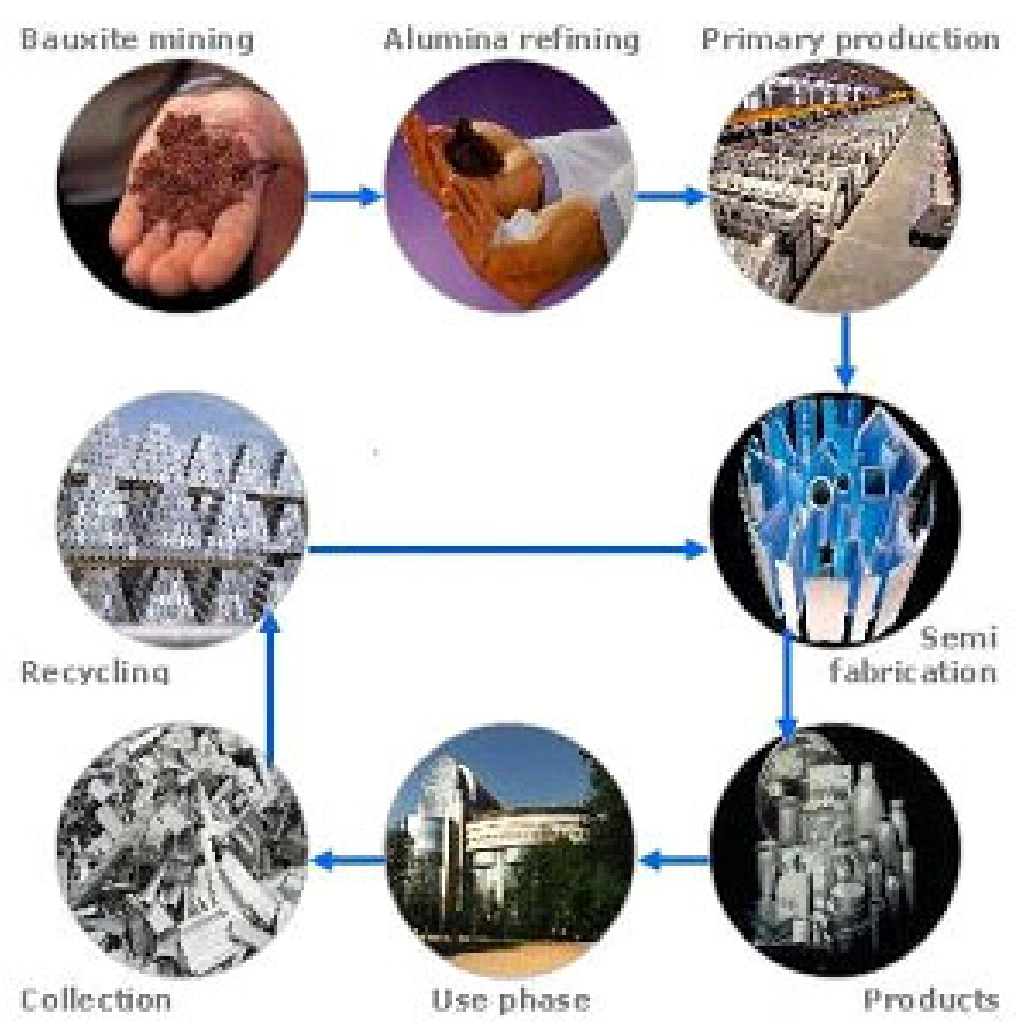

Figure 2.2 Life-cycle of aluminium [5]

The primary smelting industry in Iceland is also expanding. World-wide, production plants are mainly located where suitable electrical energy resources are available. In 1998, world-wide production of primary aluminium was about 22.7 million tonnes per year for and installed capacity of $\mathbf{2 4 . 8}$ million tonnes.

World-wide trends in production of aluminium are shown in Figure 2.3. Since 1950, the aluminium output factor increased by a factor 13. making aluminium the most highly consumed metal after steel. As we can see in Figure 2.3, the biggest producer in the world is China with almost 13 millions tonnes of production of aluminium. 
The other main production areas are North America ( 6 millions tonnes), Europe (5 millions tonnes). In Europe the main producing countries are Germany, France, Spain, UK and Norway.

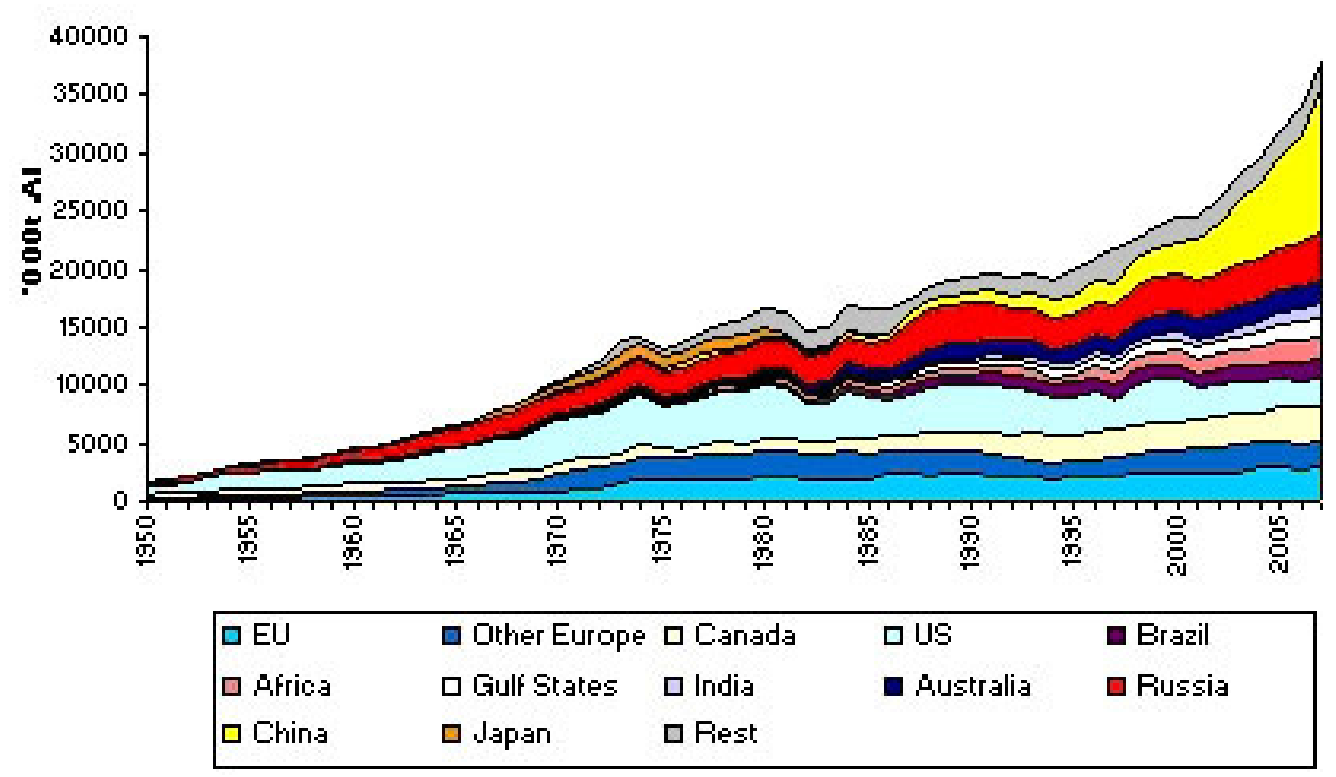

Figure 2.3 History of primary aluminium production Main producing countries and regions from 1950-2007 [5]

\subsubsection{The development of aluminium as a product}

The discovery and the first commercial applications of aluminium took place at the $19^{\text {th }}$ century. The enthusiasm for new materials and their possibilities was enormous.

- Transport

Aluminium usage in automotive applications has grown more than $80 \%$ in the past 5 years. A total of about $110 \mathrm{~kg}$ of aluminium/vehicle in 1996 is predicted to rise 250 $\mathrm{kg}$ by $2015[6,7]$. Aerospace aluminium alloys with the addition of scandium it's commonly use in aerospace industry.

For the transport very important is the combination of acceptable cost, low component mass (coming from its low density), adequate mechanical properties and ease of fabrication.

Large series car production now includes aluminium as engine castings, wheels, radiators and increasingly as body parts. For general production the 5000 and 6000 series alloys provide adequate strength combined with good corrosion resistance, high toughness and ease of welding. 
Aluminium and its alloys is the prime material of construction for the aircraft industry, $70 \%$ of aircraft airframe is made from Al-alloys. In aircraft the very strong 2000,7000 and 8000 series alloys are preferred, and in military vehicles the weldable 7000 series alloys can provide ballistic properties to match steel armour [8]. Marine alloys, these alloys with their salt-water resistance are used for boat building and shipbuilding [9].

- Packaging

The 1000 series alloy is successfully used of for containers and foil food wrapping to use their good corrosion resistance and barrier properties against UV light, moisture and odour. Foil is easy to form, attractively decorated and can be combined with plastic, paper or any other material.

The most significant use of aluminium in packaging has been in the production of beverage cans which incorporate the "easy open ring pull" in the lid. This has rapidly grown to some $15 \%$ of all aluminium consumption and gives one hundred thousand million cans a year $[8,10]$.

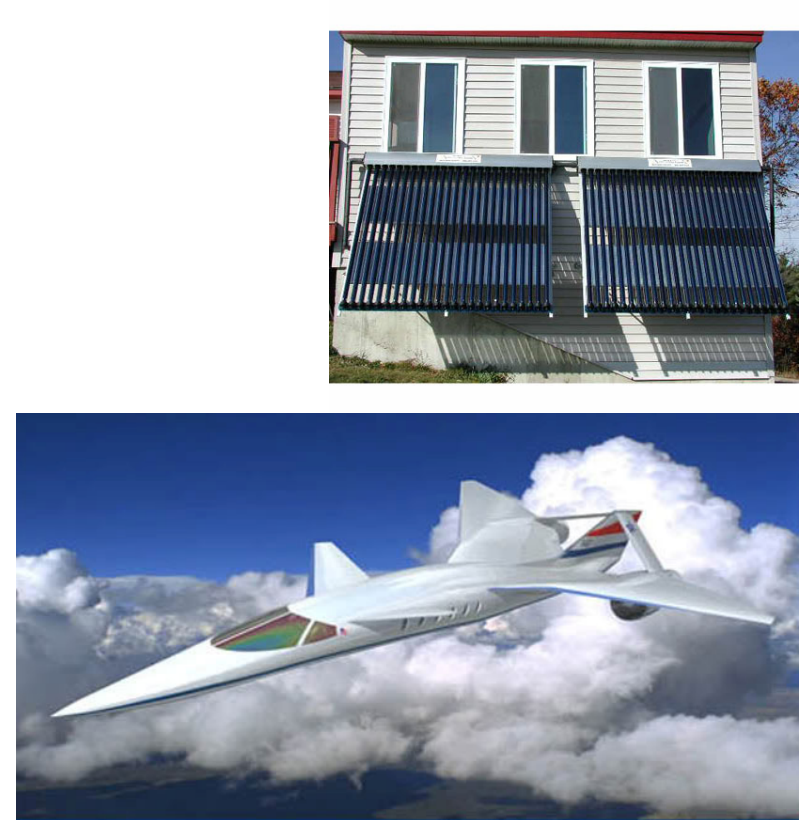

Figure 2.4 Applications of aluminium alloys [5]

- Building and architecture

Aluminium is commonly used in buildings for a wide spectrum of applications. These include windows, doors, front for shops and prestigious buildings. Aluminium has appearance similar to other painted metals. In architecture, aluminium may also be used as decorative effects.

\subsubsection{Classification of aluminium alloys}

There are two principal classifications, casting alloys and wrought alloys. $85 \%$ of aluminium is used for wrought products, like rolled plate, foils and extrusions. Cast aluminium alloys yield cost effective products due to the low melting point, although they have lower tensile strengths and ductility than wrought alloys.

The alloys used for casting contain a higher amount of alloying additions than those used for wrought products. The addition of alloying elements has the effect of improving the castability of the alloys [1,2].

Cast alloys, use a four to five digit number with a decimal point. The digit in the hundreds place indicates the main alloying elements, while the digit after the decimal point indicates the form (cast shape or ingot). 
- $1 x x . x$ series min $99 \% \mathrm{Al}$

- 2xx.x series copper

- 3xx.x series silicon, copper and/or magnesium

- 4xx.x series silicon

- 5xx.x series magnesium

- 7xx.x series zinc, magnesium and possibly copper

- $8 x x . x$ series lithium

Temper designation system of age hardening alloys follows the cast designation number with a dash, letter and potentially one to three digit numbers. The definitions for the tempers are $[8,11]$.

F - fabricated for a certain strength level $\left(F_{35}=R_{m} \geq 350 \mathrm{MPa}\right)$

T- thermally treated

T1- cooled from hot working or casting and naturally aged (at RT)

T2- cooled from hot working, cold-worked and naturally aged

T3- solution heat treatment and cold worked

T4- solution heat treatment and naturally aged

T5- cooled from hot working or casting and artificially aged (at elevated temp.)

T6- solution heat treated and artificially aged

T7- solution heat treated and stabilized

T8- solution heat treated, cold worked and artificially aged

Therefore, the standard aluminium temper designation system is also applicable to heat treatable aluminium castings. The $0, \mathrm{~T} 1, \mathrm{~T} 4, \mathrm{~T} 5, \mathrm{~T} 6$ and $\mathrm{T} 7$ tempers are used for aluminium cast alloys.

Aluminium casting alloys have been applied to various automobile parts for a long period. As a key trend, the material for engine blocks, which is one of the heavier parts, is being switched from cast iron to aluminium resulting in significant weight reduction. Aluminium engine blocks increased by the year 2000 to about $50 \%$ of all cars because of their good thermal conductivity and low thermal expansion $[12,13]$.

Casting alloys are used to produce dimensional complex shapes. Alloys with good castability must be able to fill the mould completely and have low sensitivity to cracking during casting [13]. Murali [14] evaluated the influence of magnesium content in the AlSi7Mg0.3 alloy with low-iron level that the absorbed energy drops significantly by about $50 \%$ with increasing magnesium content from 0.32 to $0.65 \%$.

\subsubsection{Aluminium-silicon cast alloys}

Castability is improved through the addition of silicon between $4-13 \%$. Near eutectic Al-Si-Mg alloys are one of the most common used casting alloys because of the flexibility provided by the high silicon contents and its contribution to fluidity, and their response to heat treatment which provides a variety of high-strength options. 
The most common and important cast aluminium alloy system is Al-Si in the eutectic composition.

The maximum amount of $\mathrm{Si}$ in hypereutectic cast alloy is of $22-24 \%$, only alloys made by power metallurgy may go to $40-50 \%$. The low thermal expansion coefficient is exploited for pistons, the high hardness of the silicon particles for wear resistance [15].

These alloys take up fine topographical details in the mould, even in thin section. Because of addition $\mathrm{Si}$ we are able to form eutectic regions and to promote the formation of strengthening precipitates through the decomposition of the supersaturated solid solution in which $\mathrm{Si}$ and $\mathrm{Mg}$ are retained from casting.

The alloys with $\sim 7 \% \mathrm{Si}$ are mostly used for permanent mould castings. Those alloys solidify quickly and exhibit no long-range segregations [10,16,17].

Faster cooling rates, as achieved by gravity or pressure die casting, promote greater amounts of pro-eutectic a-Al than equilibrium and finer eutectic particle spacing.

The application of Al-Si alloys was studied by Flinn and Sicha [18, 19]. They presented that due to their excellent castability and good compromise between mechanical properties and lightweight, aluminium silicon alloys are the most important and widely used casting alloys in order to get components with complex shapes.

- Aluminium-silicon system

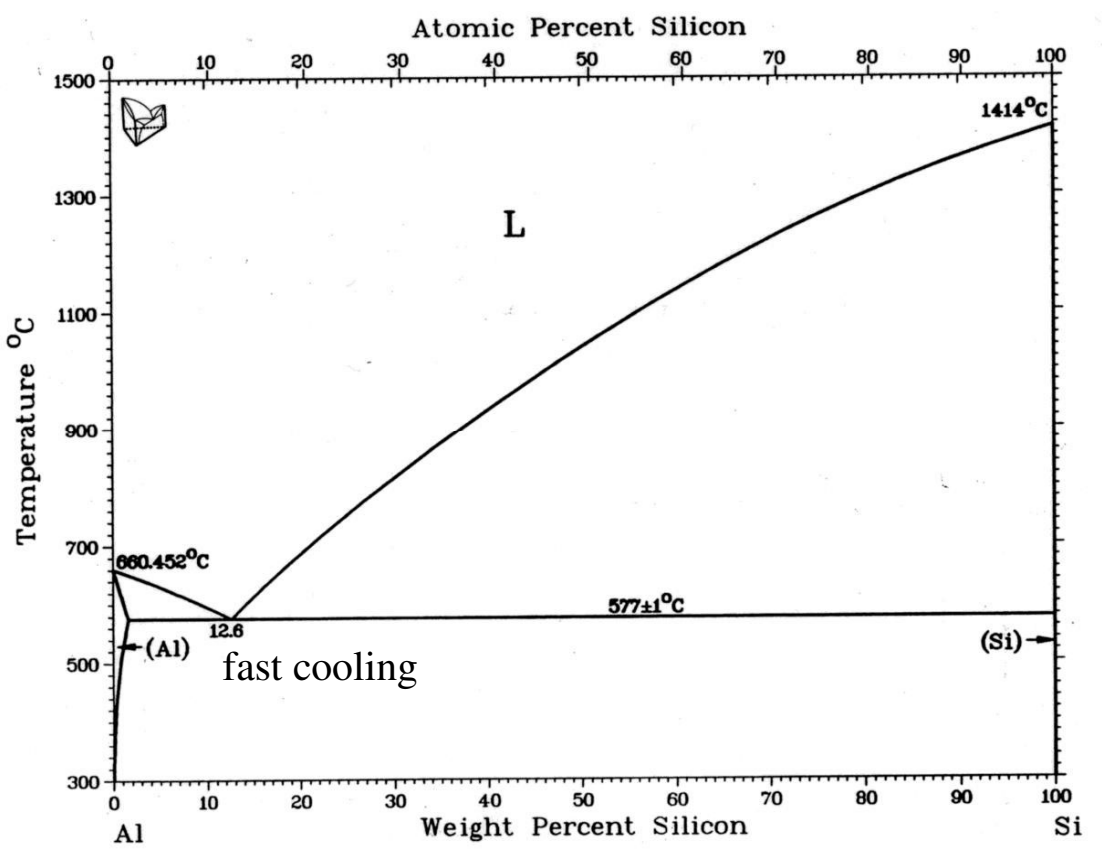

Figure 2.5 Al-Si phase diagram [16] 
The Al-Si phase diagram is an example of a eutectic system, where each element has little, if any solubility in the other. Aluminium melts at $660^{\circ} \mathrm{C}$ while silicon melts at $1414^{\circ} \mathrm{C}$. The diagram (see Figure 2.5 ) shows the eutectic at $12.6 \mathrm{wt} . \% \mathrm{Si}$ and $577^{\circ} \mathrm{C}$. The maximum solubility of $\mathrm{Si}$ in $\mathrm{Al}$ is approximately $1.65 \%$ at $577^{\circ} \mathrm{C}$, and the solubility decreases with decreasing temperature. There is virtually no solubility for $\mathrm{Al}$ in $\mathrm{Si}$ at any temperature to the melting point.

Precipitation of Si does not produce any significant strengthening but causes a volume expansion doing to the diamond structure of $\mathrm{Si}[20]$.

\subsection{Strengthening mechanisms}

\subsubsection{Heat treatment of aluminium alloys}

Pure aluminium is too soft (has a tensile strength of about $40 \mathrm{~N} / \mathrm{mm}^{2}$ and a proof strength of about $10 \mathrm{~N} / \mathrm{mm}^{2}$ at RT) for most structural applications and therefore is alloyed with several elements to improve its ductility, thermal stability, corrosion resistance and increase strength. The optimum strengthening of aluminium is achieved by alloying and heat treatments. Strength at higher temperature is improved by solid-solution and second-phase hardening because at least for temperatures exceeding those of the precipitation hardening range $\left(>230^{\circ} \mathrm{C}\right),[20$, 21].

Al-alloys that can be heat treated to form strengthening precipitates are called heat treatable alloys. Pure aluminium is not heat treatable because not such particles can form while many heat treatable aluminium alloys are not weldable because welding would destroy the microstructure produced by careful heat treatment [22].

Magnesium after heat treatment increases substantially strength, but at the expense of ductility.

Al alloys of the Al-Si-Mg system are now being used to replace steel car body components and are subject of several studies [23, 24]. The strengthening of Al-Si$\mathrm{Mg}$ alloy is based on precipitation hardening by Mg-Si precipitations. Heat treatments have three main stages: solution heat treatment, quenching and ageing.

Age hardening is the most important process to improve the mechanical properties of aluminium alloys. It requires a solid solution with a decreasing solubility of the alloying elements with falling temperatures, for instance $\mathrm{Al}-\mathrm{Mg}_{2} \mathrm{Si}, \mathrm{Al}^{-} \mathrm{Al}{ }_{2} \mathrm{Cu}$.

- Natural age hardening, which takes approximately from 5 to 8 days

- Artificial age hardening, which can last between 4 and 50 hours at different temperatures between $100^{\circ} \mathrm{C}$ and $200^{\circ} \mathrm{C}$.

Alloys $2 x x x, 3 x x x, 6 x x x$ and $7 x x x$ can be strengthened by ageing.

Precipitation hardening is a treatment technique used to increase the yield strength of materials, which delay the movement of dislocations or defects. 
All heat treatable Al-alloys are strengthened by precipitation hardening, which involves raising the temperature of the alloy into the single phase region so that all of the precipitates dissolve. After the fast cooling, the precipitation can form slowly at RT (natural aging) and faster at elevated temperature $\left(100-200^{\circ} \mathrm{C}\right)$ - artificial aging [25].

Scanning and isothermal dilatometry are efficient tools to study precipitation kinetics of systems, which are connected with a change of atomic volume $>10 \%$. In the case of AlSiMg alloys, Si precipitation can be observed by dilatometry [26], but $\mathrm{Mg}_{2} \mathrm{Si}$ not. Understanding of the precipitation kinetics of $\mathrm{Si}$ in Al-Si and Al-Si-Mg alloys as well as the influence of thermal treatment with different cooling rates after solution treatment were study by Lasagni [27].

$\mathrm{Mg}-\mathrm{Si}$ precipitates are the strengthening phase in Al 3xxx alloys.

\subsection{Casting process}

Casting is the most economical way to transfer raw materials into readily usable components, is a manufacturing simple not expensive way of forming aluminium. Cast aluminium alloys possess many benefits such as better corrosion resistance, high strength to weight ratio and excellent castability [28].

Aluminium castings are very powerful and versatile techniques for manufacturing semi- or finished products with intricate shapes. Those techniques are continuously improved and developed to satisfy the user needs and to penetrate new markets.

Innovations are mainly oriented to the automobile sector which is the most important market for castings. This continual improvement and development will ensure that aluminium castings continue to play a first role in this field. Casting is most often used for making complex shapes that would be otherwise difficult or uneconomical to produce.

The size of cast elements can be from a few grams (for example a watch case) to several tones (marine diesel engine) and the shape from simple (manhole cover) to complex (6-cylinder engine block).

Al-Si-Mg alloys are one of the most common used casting alloys because of the flexibility provided by the high silicon contents and its contribution to fluidity, and their response to heat treatment which provides a variety of high-strength options. Pressure die casting, permanent mould casting is usually used for producing the aluminium and magnesium alloys components $[29,30]$. Pressure die casting method is very expensive and time-consuming because of the design and recurring modification of the mould. Conventional pressure die castings cannot be heat treated due to gas trapping [31]. Permanent mould casting is usually difficult to manufacture complicated castings because of high solidification velocity of the melt.

One of the major drawbacks for conventional or even more advanced casting techniques and segregations is the formation of defects such as porosity. Of many such casting techniques available, squeeze casting has greater potential to create less defective cast components. 
Generally, the squeeze casting- fabricated engineering components are fine grained with excellent surface finish and have most no porosity. They come in a variety of shapes and size. The mechanical properties of these parts are significantly improved over those of conventional castings and more sophisticated casting routes of pressure or gravity die casting.

\subsubsection{Gravity die casting}

In this technique, the mould is generally not destroyed after each cast but is permanent, being made of cast iron or some special steel alloy with good resistance to high temperatures. The method is often used for casting zinc and aluminium alloys.

The advantages of the gravity die casting are good mechanical properties, high dimensional accuracy and high surface smoothness. Disadvantages are high mould cost and rather slow.

A schematic view in Figure 2.6 shows the main parts constituting a classical mould for gravity die casting. Cores (inner parts of the mould) are generally made of bonded sand. Die casting mould can crack when the stress becomes bigger than the strength of the steel [32].

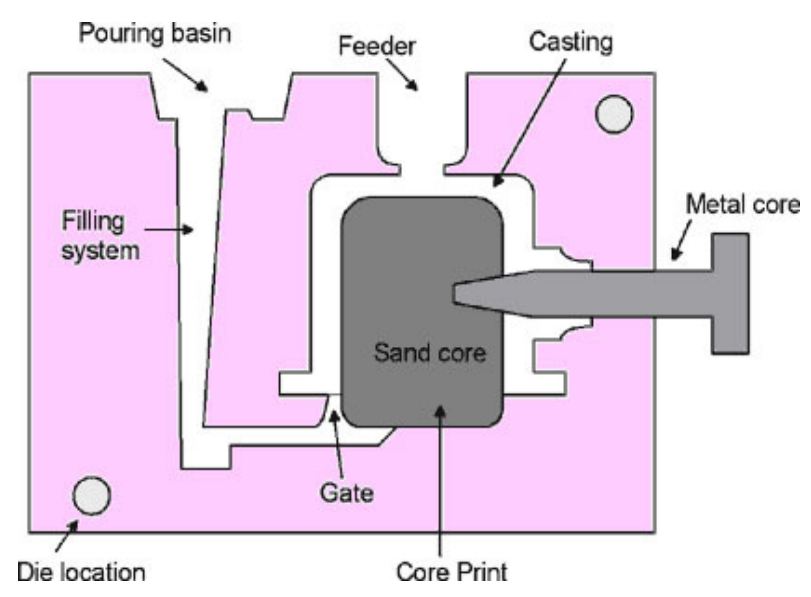

Figure 2.6 Schematic view of gravity die casting [32]

These stresses consist of residual stresses produced during tool manufacturing due to machining, grinding or heat treatment. The second type of stress is stress produced during die casting - thermo-mechanical stresses.

Residual stresses could be minimal, if mould is designed optimally and machining and heat treatment well done. The mould is repeated heated and cooled down during the process, which generates thermal stresses, which can produce thermal fatigue of the material. Thermal fatigue resistance also decreases in materials with lower thermal stability of mechanical properties and if the heat treatment is done at lower annealing temperature [33]. 
Figure 2.7 shows the optical microstructure of as cast AlSi7Mg0.3 alloy. The structure is fully dendritic.

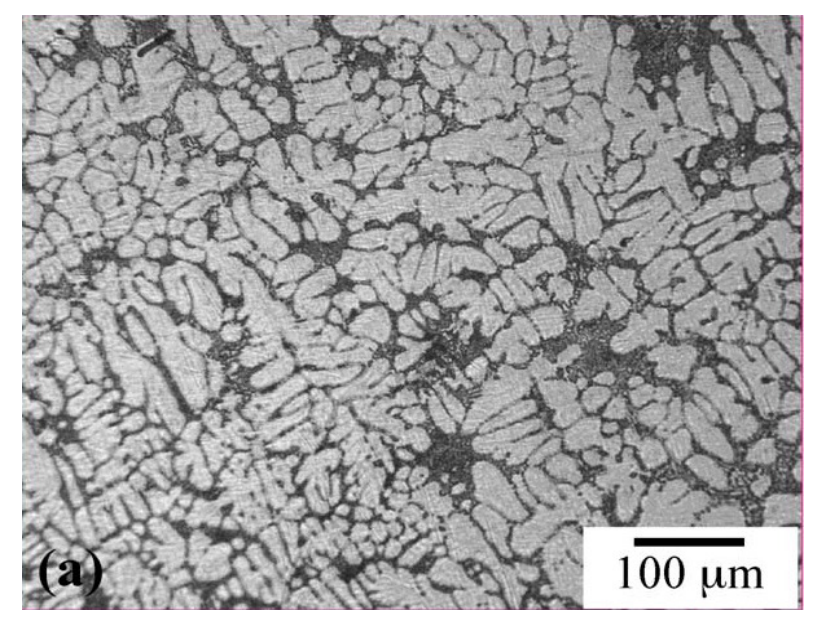

Figure 2.7 Optical Microscopy of as cast of A356 samples produced by gravity die casting [34]

\subsubsection{Low pressure die casting}

A metal mould is positioned above a furnace containing molten metal. A riser tube extends from the bottom of the die into the molten metal. Low pressure air (15-100 $\mathrm{kPa}$ ) is introduced into the furnace. This makes the molten metal rise up the tube and enters the mould cavity with low turbulence (see Figure 2.8). Once the casting has solidified, the pressure is released and the molten metal falls back into the bath. After cooling, the mould is opened and the casting extracted in preparation for the next cycle.

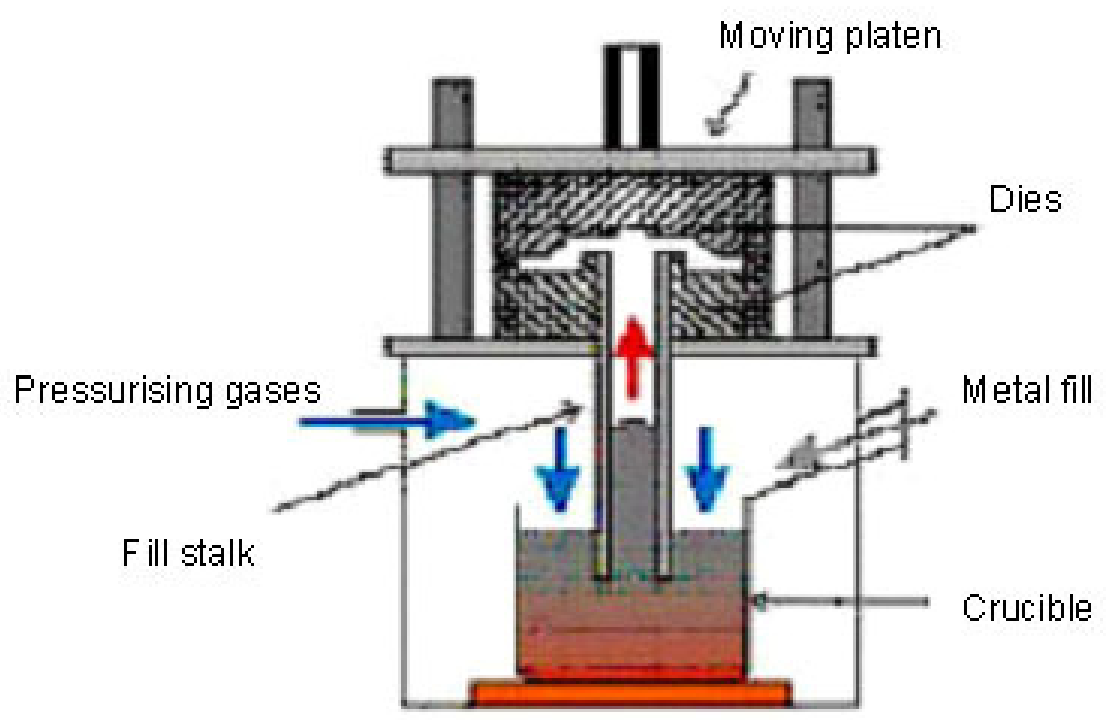

Figure 2.8 Schematic view of a low pressure die casting machine [13] 
The mould filling is relatively slow to minimise turbulence and air entrapment. In order to obtain well-fed casting, the mould must be controlled to promote the directional solidification from the end of the cavity back to the riser tube [13].

The process usually produces castings with low amount of porosity. Low pressure die casting (LPDC) is mostly used for automotive parts like cylinder heads, wheels. The alloys mostly used are AlSi12, AlSi7Mg.

Advantages of low pressure die casting are that little work remains after casting; it's easy to automate, lower workshop costs than in high pressure die casting, and have better mechanical properties than in conventional sand casting.

Unfortunately, only materials with low melting points can be cast. LPDC has lower productivity than high pressure die casting and the mould is more expensive than in conventional casting.

Figure 2.9 (b) [35] shows the microstructure of as cast A356 alloy produced by low pressure die casting.

It can be seen that the white phases are a-Al primary solid phases, and the grey phases are Al-Si eutectic in the interdendritic region.
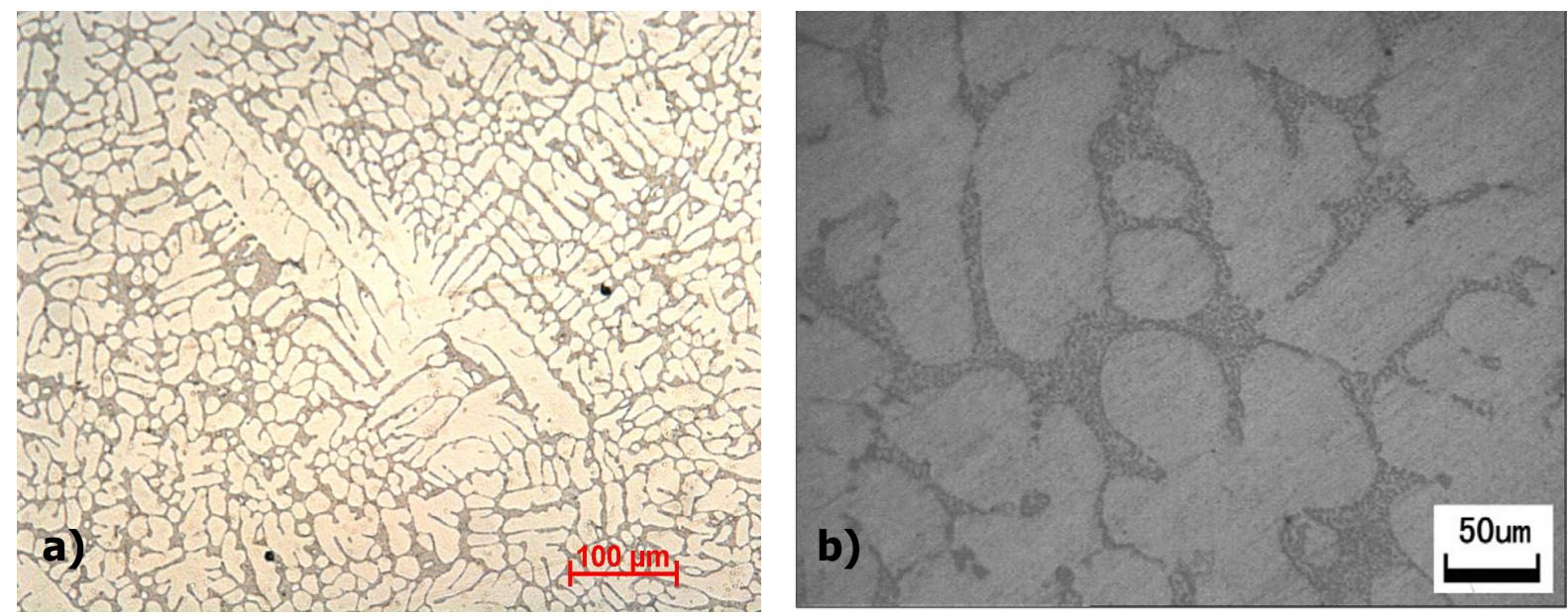

Figure 2.9 Light Optical Microscopy micrographs of low pressure die casting as-cast structure of AlSi7Mg alloy

\subsubsection{Squeeze casting}

Of many available casting techniques, squeeze casting has greater potential to create less defective cast components [36]. Generally, the squeeze casting fabricated engineering components are fine grained with excellent surface finish and have mostly no porosity. They come in a variety of shapes and size.

The mechanical properties of these parts are significantly improved over those of conventional castings and more sophisticated casting routes of pressure or gravity die casting. It is mainly used to fabricate high integrity engineering components with or without reinforcement [37]. 
Pennington [38] showed that yield strength is improved by $10-15 \%$ and elongation and fatigue strength by as much as $50-80 \%$. Dimensional accuracy is similar to those of die casting: $0.25 \mathrm{~mm}$ in $100 \mathrm{~mm}$ to $0.6 \mathrm{~mm}$ in $500 \mathrm{~mm}$.

The squeeze casting (SC) is a method that is a combination of casting and forging. After the melt filled the mould without turbulence it is exposed to a high pressure and starts to solidify. The pressure is during the whole solidification process what brings plastic deformation to comply with shrinkage, which improve the mechanical properties of the casting as compared to conventional casting.

As shown in Figure 2.10, the molten metal is poured into the bottom half of the preheated die (a). As the metal starts solidifying, the upper half closes the molten and applies pressure during the solidifications process (b). After solidification the upper mould section is removed and the casting is ejected by the aid of the ejector (c). The amount of pressure thus applied is not so important than in forging, and parts of great detail can be produced. The squeeze castings improved mechanical properties of the alloy and the porosity is slightly.

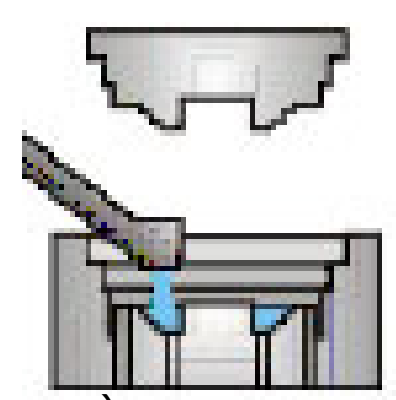

a)

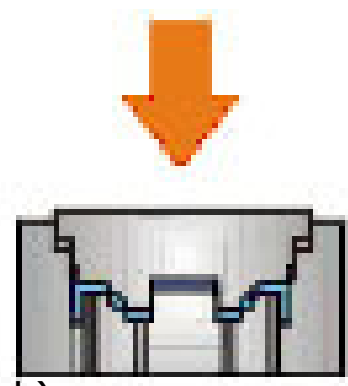

b)

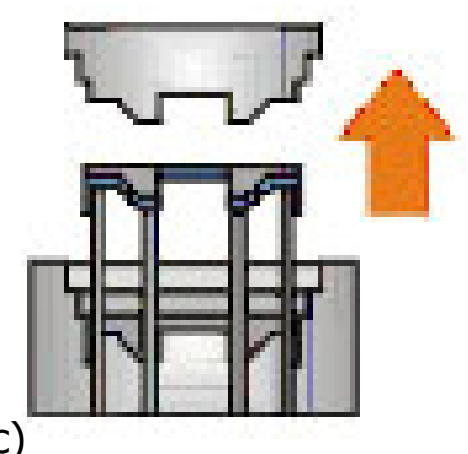

c)

Figure 2.10 Direct squeeze casting principle [39]

Squeeze cast products have better mechanical properties compared to their conventionally cast counterparts due to higher density, finer grain size and more homogeneous microstructure [39, 40,41].

A typical squeeze cast microstructure of Al-Si alloy shows Figure 2.11. 


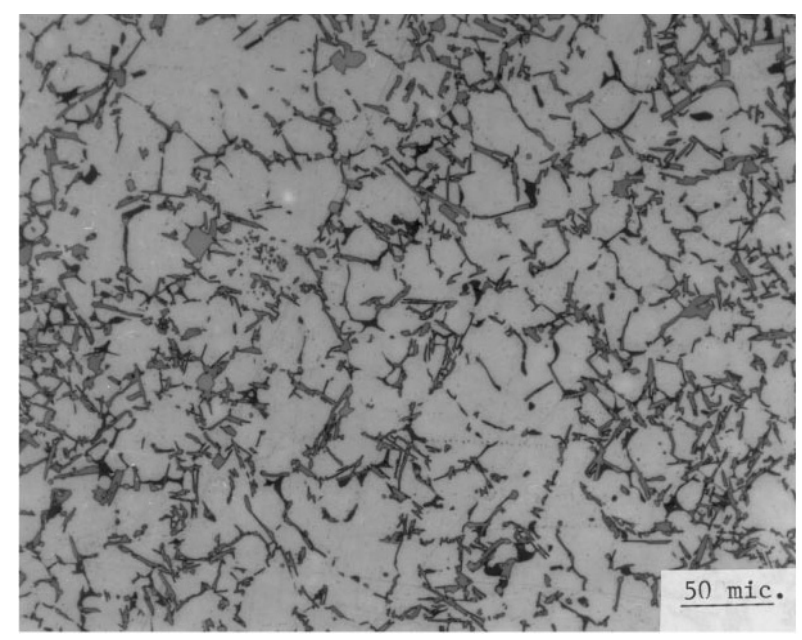

Figure 2.11 Light Optical Microscopy shows the as-cast structure of AISi7 alloy [42]

In indirect squeeze casting (1000-1200 bar), the melt is poured into the casting chamber, which transfers it with laminar flow into the die by a hydraulic piston (see Figure 2.12). The high pressure ensures a better heat transfer, resulting in a higher rate of solidification, which leads to a finer microstructure and improved mechanical properties.
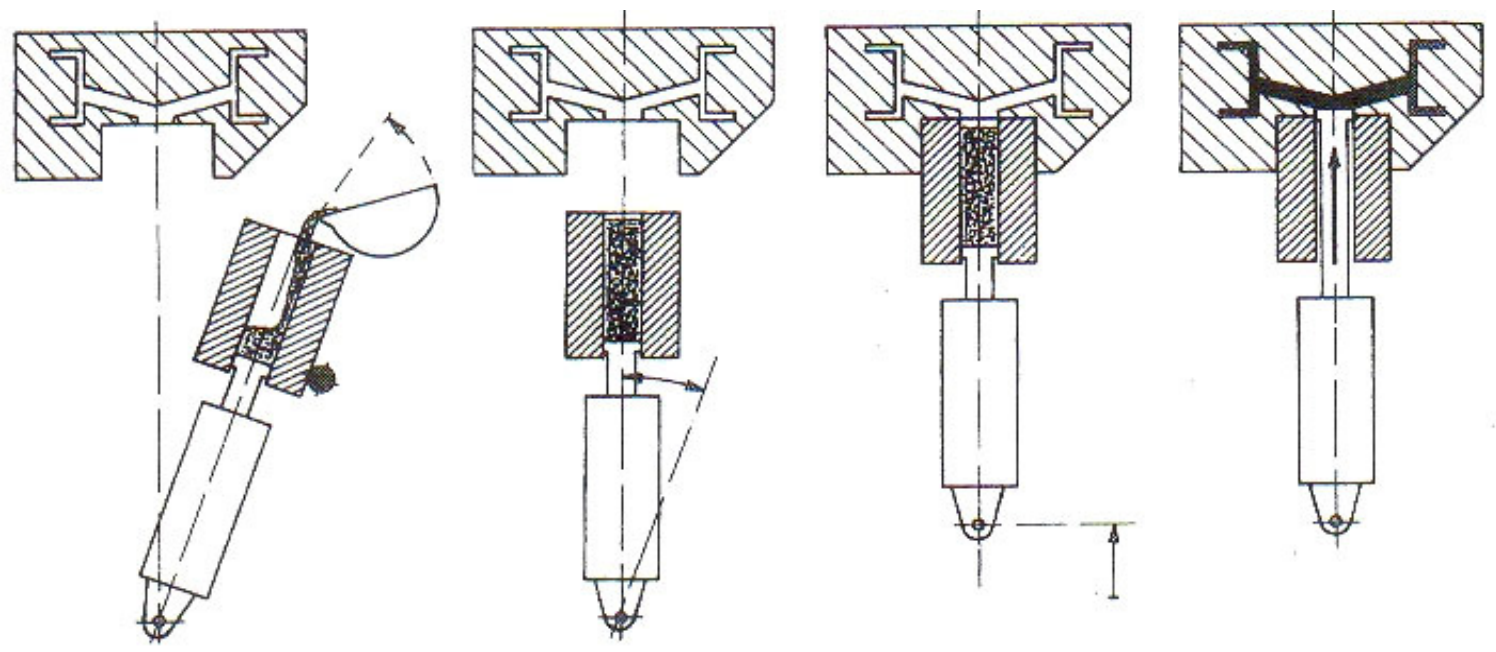

Figure 2.12 Schematic representation of the indirect squeeze casting process [37]

\subsubsection{Microstructure, porosity and shrinkage in Al-cast alloys}

The typical microstructure of as hypoeutectic cast-aluminium alloys consists of primary aluminium dendrites surrounded by eutectic. The structure of the eutectic depends on the solidification rate and is very important for the properties of the material. The microstructure of conventional cast samples because of the morphology growing solid-liquid is fully dendritic. 
The microstructural study of Al-Si-Mg alloy with stainless steel (casting) has been investigated and focused on the both microstructures. Porosity and incomplete bonding were observed [43].

Jiang and Fan [35] studied the microstructure and mechanical properties of A356 alloy produced by low pressure die casting. The result of their study was that the microstructure of A356 alloy produced by LPDC mainly consists of a-Al phase, eutectic silicon particles and $\mathrm{Mg}_{2} \mathrm{Si}$ phases. After $\mathrm{T} 6$ heat treatment, spherical eutectic silicon particles are distributed in the interdendritic region. The structure was finer and less porosity was observed compared to gravity die casting.

The natural progression of filling followed by solidification often produces internal defects, like cracks, gas entrapment, shrinkage porosity that leads to poor mechanical properties. Cracks have been found by Merlin [44] in the interdendritic eutectic region where the microstructural analysis has revealed shrinkage microporosity, cracked eutectic silicon with different size and morphology in the as cast condition.

Most aluminium casting alloys contract about 3-6 vol.\% on solidification, which can produce porosity. This porosity can reduce the mechanical properties of the casting.

The amount of porosity in a casting depends on:

- solidification rate, and direction

- gas content,

- metal cleanliness,

- pressure in the casting

- and modification.

All those factors have been study by Fang and Granger [45]. The casting had a water-cooled chill at one end and was solidified directionally; it means the feeding was more then adequate to prevent shrinkage. The amount and size of porosity were measured by quantitative metallography using distance from the chill. Thermocouples fixed in the mould record the solidification rate at these sections. Figure 2.13 shows the amount of porosity formed in the casting.

To reduce the amount of porosity and pores, some of casting processes apply pressure to solidifying casting.

Shrinkage porosity appears in all of the casting processes. It is cavity formed due to the solidification of metal that is not fed from a supply. If there is a liquid in a mould und the gate freezes, than the casting must be smaller than the cavity shape due to solidification shrinkage. The metal can either shrink away from the wall of the mould or form a cavity within the casting. Usually in this case, section of casting that is divorce from the gate form shrinkage voids or pores. Figure 2.14 shows typical shrinkage porosity of Al-Si alloy. 


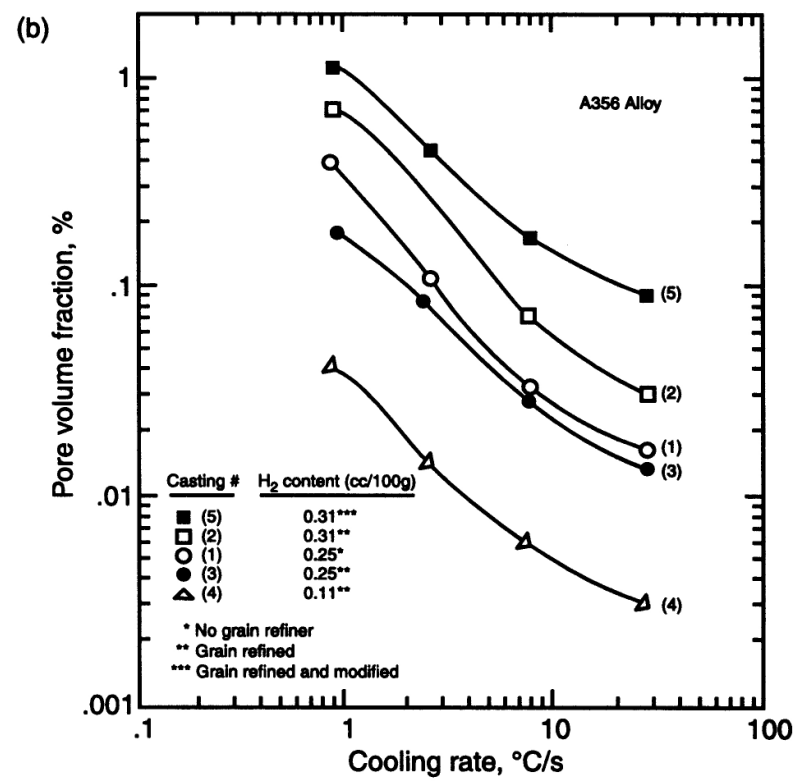

Figure 2.13 Volume fraction of porosity in directionally solidified A356 alloy castings [45]

Figure $2.14 \mathrm{~b}$, shows a casting defect (a pore) caused by the shrinkage of liquid during solidification of AlSi12. The microstructure consists of grey plates of silicon in a white matrix which is rich in aluminium. Although the alloy is slightly hypoeutectoid in composition, there is evidence that solidification started with primary aluminium dendrites. This is because the sample did not solidify under equilibrium conditions. Equilibrium solidification would require painfully slow cooling rates, not achievable in industrial practice.
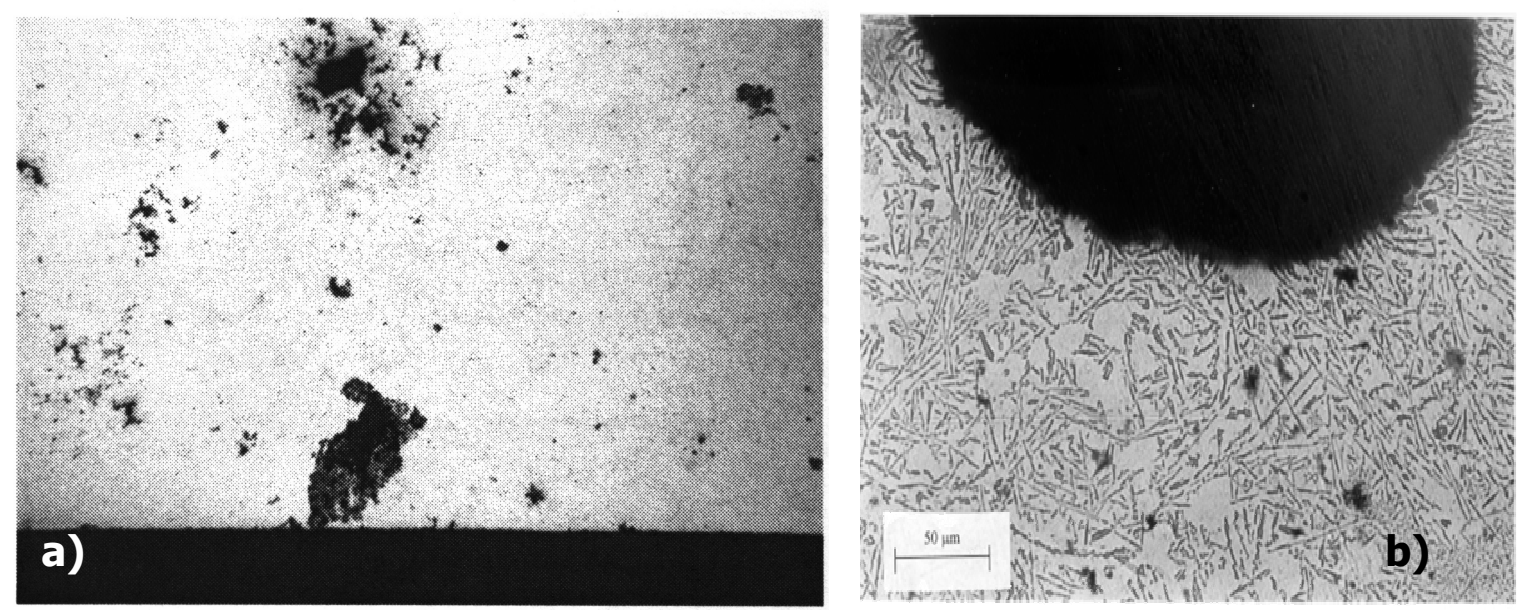

Figure 2.14 a) Typical shrinkage porosity in a casting [46], b) pore - castings defects [47] 


\subsubsection{Effect of solidification rate}

Rate of the solidification has an important influence on the properties of castings [13]. An alloy solidifies within a temperature interval defined by the composition of the alloy. Solid phase precipitates anywhere in the melt. Dendrites grow and form a network surrounded by melt in the shape of curved channels between the dendrites. The dendrites are small, what allows a transport of melt. When the solidification process proceeds, the dendrites become thicker and welding together defining a solid network. The channels making thinner become more difficult to supply melt to the first solidified parts, close to the mould. The shrinkage in the last part of the solidification may result pores everywhere between the dendrites in the casting.

Casting that get frozen quickly can tolerate quite high contents of gas, and after slowly cooling porosity is easily formed. Oswalt and Misra [48] studied solidification rates of two different Al alloys (A356 and A357). They used dendrite arm spacing to characterize the solidification rate of the samples. To obtain different strength levels in each alloy, different aging times were employed. Increasing the aging time or adding magnesium will give us better properties of the casting. Looking to the Figure 2.15 we can see that solidification rate is indicated by the numerical values for the secondary dendrite arm spacing (SDA). SDA of the A356 alloy changing from about $25 \mu \mathrm{m}$ which correspond to local solidification time of about $20 \mathrm{~s}$ to about $125 \mu \mathrm{m}$ for a freezing time of $20 \mathrm{~min}$.

Solidification experiments have been carried out on an Al-Si alloy as a function of temperature gradient. The samples were solidified under steady-state conditions with a constant growth rate at different and constant temperature gradients at different growth rates [49].

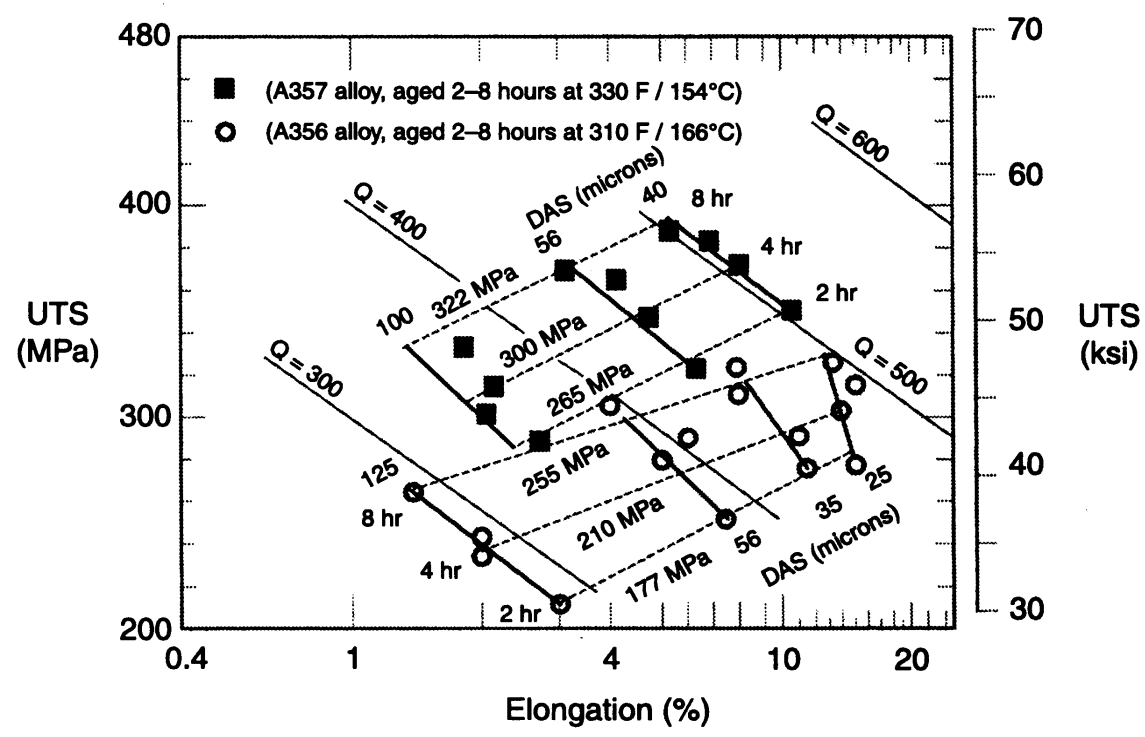

Figure 2.15 Tensile strength and quality of a356-T6 and A357-T6 alloy castings [48] 
In all processes the solidification takes place through the formation of dendrites from liquid solution. The cells contains of dendritic structure corresponds to the dimensions separating the arms of primary and secondary dendrites. The dendrites are controlled by solidification rate (see Figure 2.16), [10].

Cooling rates directly control dendrite arm spacing, which influences property development and substantially improves ductility, see Table 2.17.

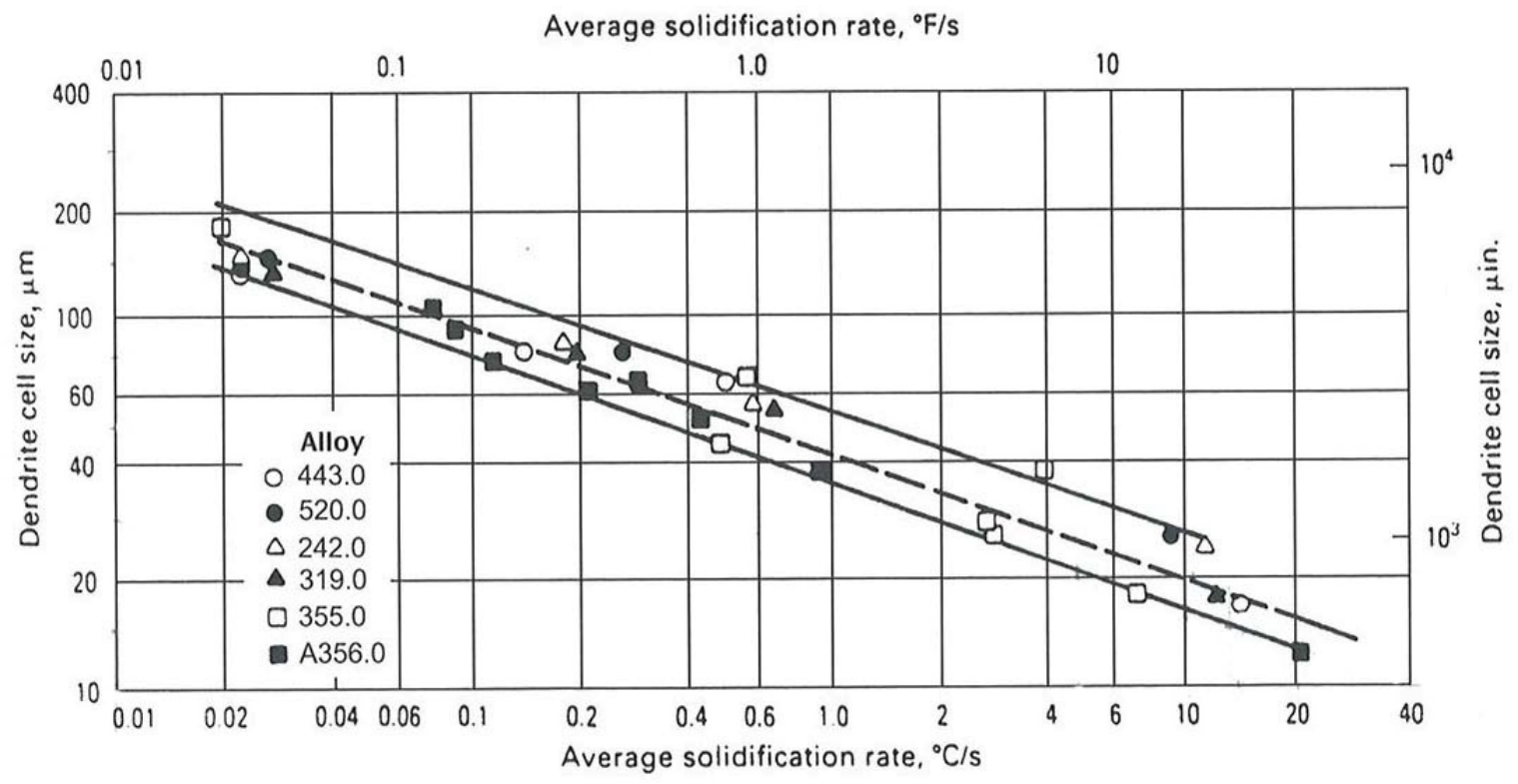

Figure 2.16 Dendrite arm spacing and dendrite cell size as a function of local solidification rate [10]

Table 2.17 Table of cooling rate and SDA for different casting process [10]

\begin{tabular}{|c|c|c|c|c|}
\hline \multirow[b]{2}{*}{ Casting process } & \multicolumn{2}{|c|}{ Cooling rate } & \multicolumn{2}{|c|}{ Dendrite arm spacing } \\
\hline & ${ }^{\circ} \mathbf{F} / \mathbf{s}$ & ${ }^{\circ} \mathrm{C} / \mathrm{s}$ & mils & $\mu \mathrm{m}$ \\
\hline Plaster, investment & 1.80 & 1 & $3.94-39.4$ & $100-1000$ \\
\hline Green sand, shell & 18.0 & 10 & $1.97-19.7$ & $50-500$ \\
\hline Permanent mould & 180.0 & 100 & $1.18-2.76$ & $30-70$ \\
\hline Die & 1800 & 1000 & $0.20-0.59$ & $5-15$ \\
\hline
\end{tabular}

Solidification rate has a significant effect on the amount and distribution of porosity in a casting. This is the primary reason why the tensile properties of aluminium cast alloys depend strongly on freezing rate. 


\subsubsection{Inserts $[50,51,52,53]$}

Magnesium surfaces subjected to heavy bearing loads or severe wear require protection. Inserts that provide protection to the surfaces of holes can be made of various materials and attached in numerous ways.

\section{- Cast-In Inserts}

Inserts in magnesium may be fixed in place by casting the magnesium around them. Cast-in insert for use in magnesium can be made of steel, brass, bronze or other metals. Cast-in inserts become securely fixed when the cast metal shrinks around them or if the outside of the insert is grooved. Very important is to ensure that stress concentrations are not set up by sharp corners or insufficient metal around the insert.

Shrinkage of the magnesium alloy around cast-in inserts can cause high residual stress in the metal surrounding the insert. This can be reducing by preheating the insert, inserts with a wall thickness of $1.3 \mathrm{~mm}(0.050 \mathrm{in}$.), see Figure 2.18 , or less preheats sufficiently from contact with the hot mould and the molten magnesium. If these design and manufacturing conditions are not followed, the high residual stresses can lead to failure of the part in service brought about by stress-corrosion cracking.
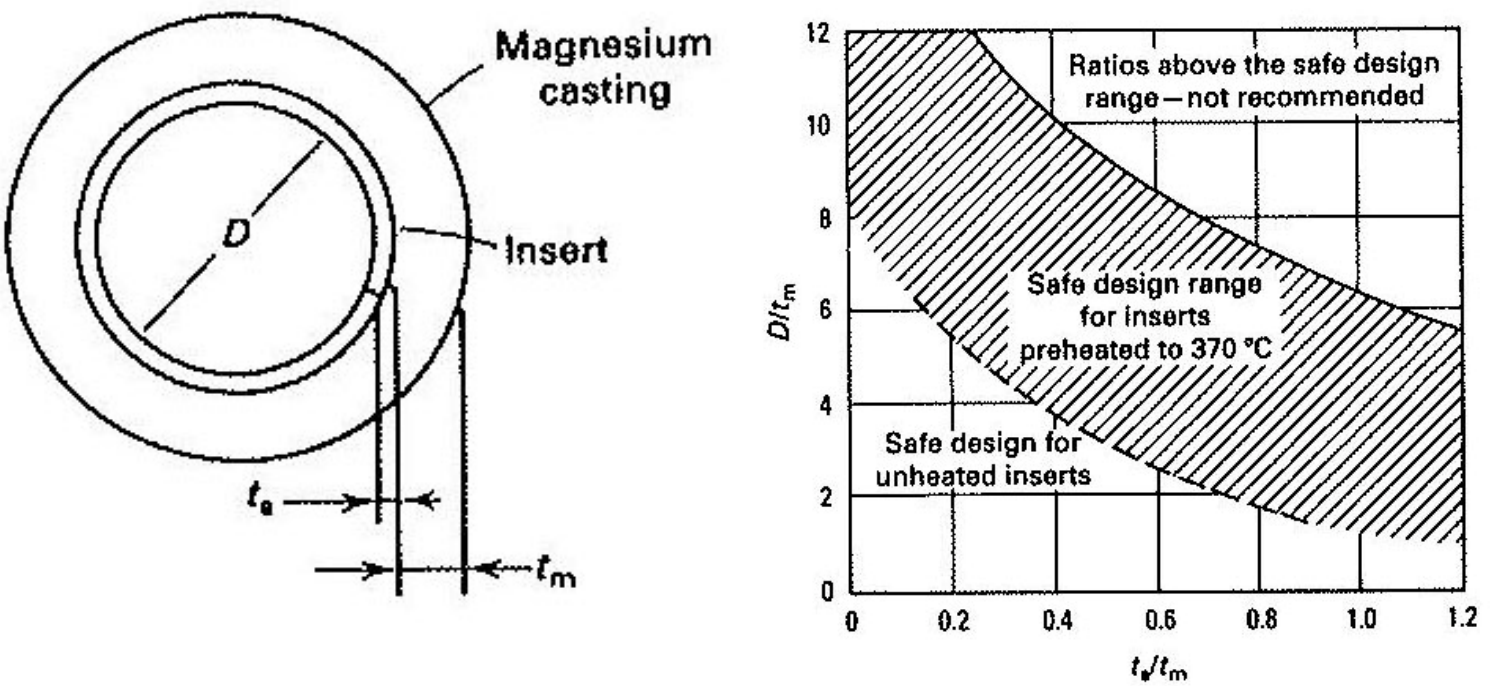

Figure 2.18 Safe design dimensions for cast-in steel inserts in magnesium alloy castings. Values apply to inserts having a wall thickness greater than $1.3 \mathrm{~mm}[50]$ 
- Press-Fit and Shrink-Fit Inserts

Because of the low modulus of elasticity of magnesium, greater interference must be used for press-fit or shrink-fit inserts in magnesium than for inserts in other metals in order to obtain sufficient gripping force. An interference of 0.5 to $1 \mathrm{~mm} / \mathrm{m}$ is usually satisfactory, but this range can be increased appreciable where high-torque loads are likely.

Inserts are more easily assembled by shrinking than be pressing. It is relatively easy to heat a magnesium part and thus expand a hole in the part so that it is large enough to receive an insert. If it's necessary, the insert can be cooled to facilitate insertion. Also assembly by pressing requires careful machining of both insert and hole, and proper lubrication. When large interferences are requiring, specifying shrink-fit inserts is best because press-fits might score the magnesium.

- Screwed-In Inserts

Various types of screwed-in inserts can be used successfully in magnesium parts. When screwed-in inserts are used, locations of treaded holes must be chosen carefully to avoid stress concentrations and to provide sufficient engagement length for the thread.

\subsubsection{Objectives of this work}

In this work, the interface between aluminium castings and steel inserts of four different samples has been investigated. The samples were developed by LKR for three different casting processes: gravity die casting, low pressure die casting and squeeze casting.

The following questions in this thesis:

- Which casting conditions produce interface reactions, and how much?

- Do interface reactions improve the bonding?

- How much residual stresses build up in Al at the interface during casting due to CTE mismatch?

- How develops the cast microstructure of the interface to the insert?

- Which casting defects influence the interface?

- Does the bonding strength depend on the age hardening of the Al-alloy? 


\section{Chapter 3}

\section{Description of the methodology}

\subsection{Materials}

Different shapes of steel inserts and different Al alloys were used: rings, rods, cubes, and tubes and $\mathrm{Al}, \mathrm{AlSi} 7$ and AlSi7Mg0.3 type of aluminium alloys are investigated in this work. The different AlSi-alloys were produced using gravity, low pressure and squeeze casting process by LKR, Ranshofen, Austria.

Alloys are listed in Table 3.1.

Table 3.1 Different alloys and steel inserts used in this study

\begin{tabular}{|l|c|c|c|}
\hline \multicolumn{1}{|c|}{ Sample } & Casting & Alloy & Insert \\
\hline Rod sample & & & St37 \\
& Gravity die casting & AlSi7 & $18-8 \mathrm{Cr}-\mathrm{Ni}$ \\
\hline & & & St37 \\
\hline Cube sample & Gravity die casting & Al (99.8\%) - A 1080 & $18-8 \mathrm{Cr}-\mathrm{Ni}$ \\
\hline Step sample & & AlSi7Mg0.3 & St52 \\
\hline Demo-axial sample & Low pressure casting & AlSi7Mg0.3 & C45E \\
\hline
\end{tabular}

\section{- Rod insert}

The gravity casting consists of two suspended rod steel inserts, which are surrounded by AlSi7 casting and one of each is trimmed (Figure 3.2). The investigated samples are described by:

- Al alloy: AlSi7

- Steel insert in gravity die casting process with different melt temperature (see Table 3.3)

- Used steel St37: diameter $10 \mathrm{~mm}$

- Mould: 10 x 100mm long

Different surface treatments (oxidized and etched) were carried out to study the effect of interface reactions $[54,55]$ investigated by SEM. 


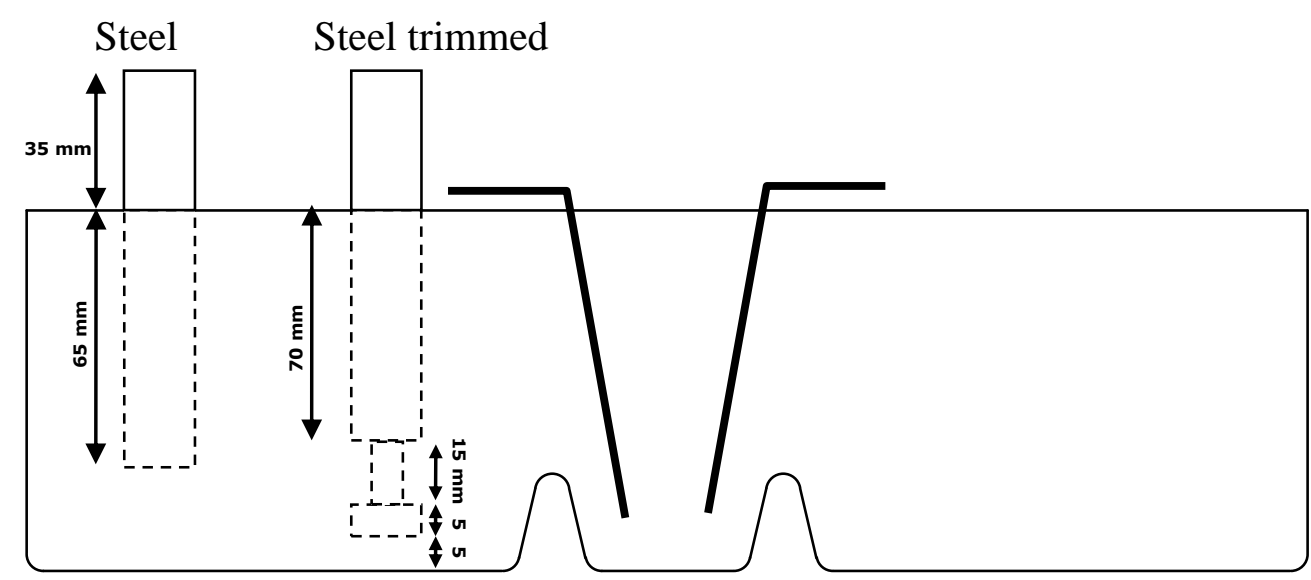

Figure 3.2 Sketch of the rod gravity cast sample

Table 3.3 Description of the investigated rod samples

\begin{tabular}{|c|c|c|c|c|}
\hline Sample Nr & Insert & Alloy & T(insert) $\left[{ }^{\circ} \mathbf{C}\right]$ & $\mathbf{T}(\mathbf{m e l t})\left[{ }^{\circ} \mathbf{C}\right]$ \\
\hline & & & & \\
\hline 2 & A & AlSi7 & 25 & 700 \\
\hline 3 & B & AlSi7 & 25 & 700 \\
\hline 5 & C & AlSi7 & 25 & 750 \\
\hline 6 & D & AlSi7 & 25 & 750 \\
\hline 7 & B & AlSi7 & 25 & 750 \\
\hline
\end{tabular}
$\mathbf{A}=$ steel St37 (no surface treatment, oxide) + trimmed
$\mathbf{B}=18-8 \mathrm{CrNi}$ steel + surface etched, no oxide
$\mathbf{C}=$ steel (no surface treatment) + polished + etched, no oxide
$\mathbf{D}=\mathbf{C}+$ trimmed

\section{- Cube insert}

Steel cubes (St37) were embedded into two different alloys: Al (99.8\%) and AlSi7Mg0.3. The mould was kept at RT, $700^{\circ} \mathrm{C}$ or at $750^{\circ} \mathrm{C}$, while the cube was immersed of RT (see Table 3.5).

a)

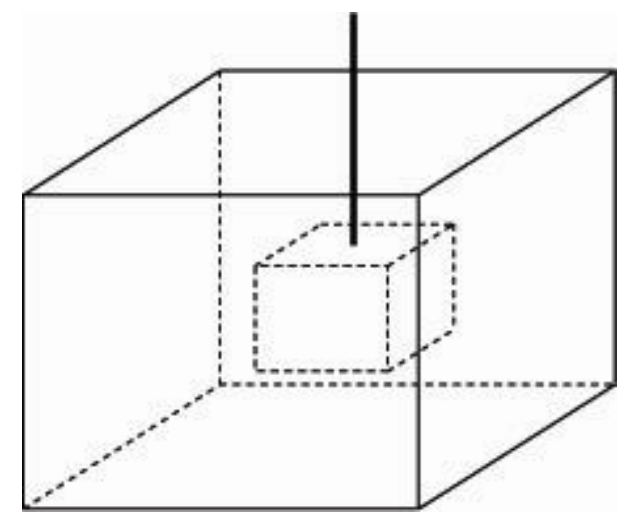

b)

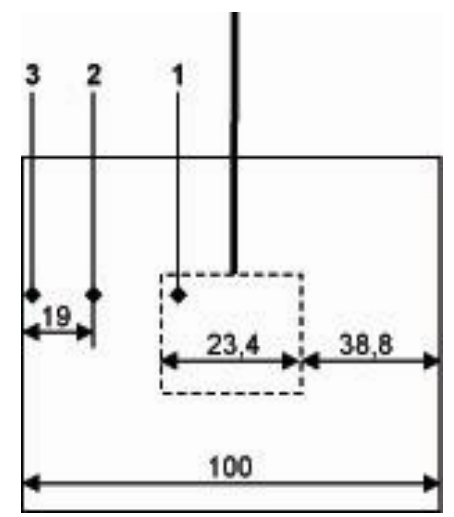

Figure 3.4 Sketch of the cube sample indicated the positions of the thermocouples 
Table 3.5 Description of the investigated cube samples

\begin{tabular}{|c|c|c|c|c|c|}
\hline $\begin{array}{c}\text { Sample } \\
\mathbf{N r}\end{array}$ & Insert & Alloy & T(insert) $\left[{ }^{\circ} \mathbf{C}\right]$ & $\begin{array}{c}\mathbf{T} \text { (mould) } \\
{\left[{ }^{\circ} \mathbf{C}\right]}\end{array}$ & \\
\hline & & & & & \\
\hline 1 & $\mathrm{~A}$ & $\mathrm{Al}(99.8 \%)$ & 25 & 700 & gap \\
\hline 2 & $\mathrm{~A}$ & $\mathrm{Al}(99.8 \%)$ & 25 & $\mathrm{RT}$ & bonding \\
\hline 3 & $\mathrm{~A}$ & $\mathrm{AlSi} M g 0.3$ & 25 & 700 & bonding \\
\hline 4 & $\mathrm{~A}$ & $\mathrm{AlSi} M \mathrm{Mg} 0.3$ & 25 & $\mathrm{RT}$ & gap \\
\hline 5 & $\mathrm{~B}$ & $\mathrm{AlSi} M g 0.3$ & 25 & 750 & \\
\hline 7 & $\mathrm{C}$ & AlSi7Mg0.3 & 25 & 750 & \\
\hline
\end{tabular}
$\mathbf{A}=\quad$ steel St37 (no surface treatment)
$\mathbf{B}=$ surface etched
$\mathbf{C}=18-8 \mathrm{Cr}-\mathrm{Ni}$ steel + surface etched

Two of each kind of samples, have been used for the experimental part. All the samples were cut perpendicular to the insert axis for slices $5 \mathrm{~mm}$ thick. After cutting the sample 4 we observe, that the steel didn't stick to the aluminium along the whole interface (Figure 4.44 A, B) but cracks had been formed in the Al-casting starting from the corners of the insert. In both of the samples 1 we observed a gap along the whole insert; see Figure 4.44 C, D. Samples 2 and 3 showed microscopically good interface.

\section{- Step shape with rings}

Step samples (Figure 3.6) contain of St52 steel inserts without surface coating (preheated to $110^{\circ} \mathrm{C}$ ), with outer diameter of $20 \mathrm{~mm}$, inner diameter of $10 \mathrm{~mm}$. Compound samples with AlSi7Mg alloy have been manufactured by low pressure die casting with $720^{\circ} \mathrm{C}$ melt temperature.

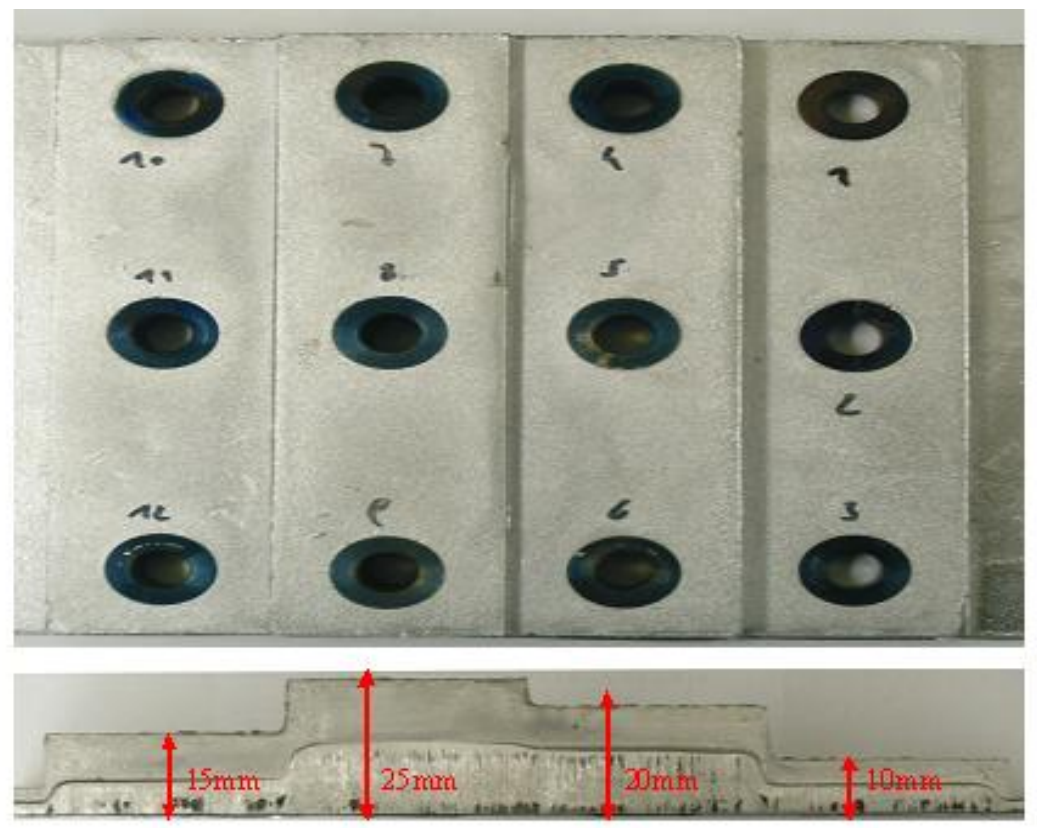

Figure 3.6 View of the low pressure die casting with different step heights $(10,15,20,25 \mathrm{~mm})$ 
The samples were cut in the middle of the thickness into two equivalent halves, only samples with step height of $25 \mathrm{~mm}$ were cut for trisect $(7 \mathrm{~mm}$ thick). Samples were separated from the array and than cut parallel to the insert axis in order to characterize the interface between aluminium casting and steel insert along its length. After the first diagonal cut in most of the samples the steel fell out of smaller half of the Al by itself. If the steel stuck to the aluminium we separated it by a second radial cut. The sample was used for the SEM and LOM in order to characterize the microstructure of the surface of the casting and the interface.

\section{- Demo-axial}

A demo-axial sample has been designed to demonstrate the potential of steelaluminium composite casting $[56,57]$ produced by squeeze casting.

It joins two inserts made from steel C45E by an AlSi7Mg cast node [56]. It was designed to withstand primarily axial (compressive or tensile) and torsional loading by force and form lock. Figure 3.7 shows an exploded drawing of the demo prototype. As the steel inserts have a complicated shape, they have been produced by CNC milling. The geometry of the steel insert is based on a tube with outer diameter of $26 \mathrm{~mm}$ and $3 \mathrm{~mm}$ wall thickness. The cross section of the steel insert smoothly varies along the axial direction from a circle to a triagonal profile and widens again to a circle. The spacer ring has no mechanical function - it merely keeps the melt from flowing into the steel inserts. The demo prototype was quenched in water directly after the casting process.

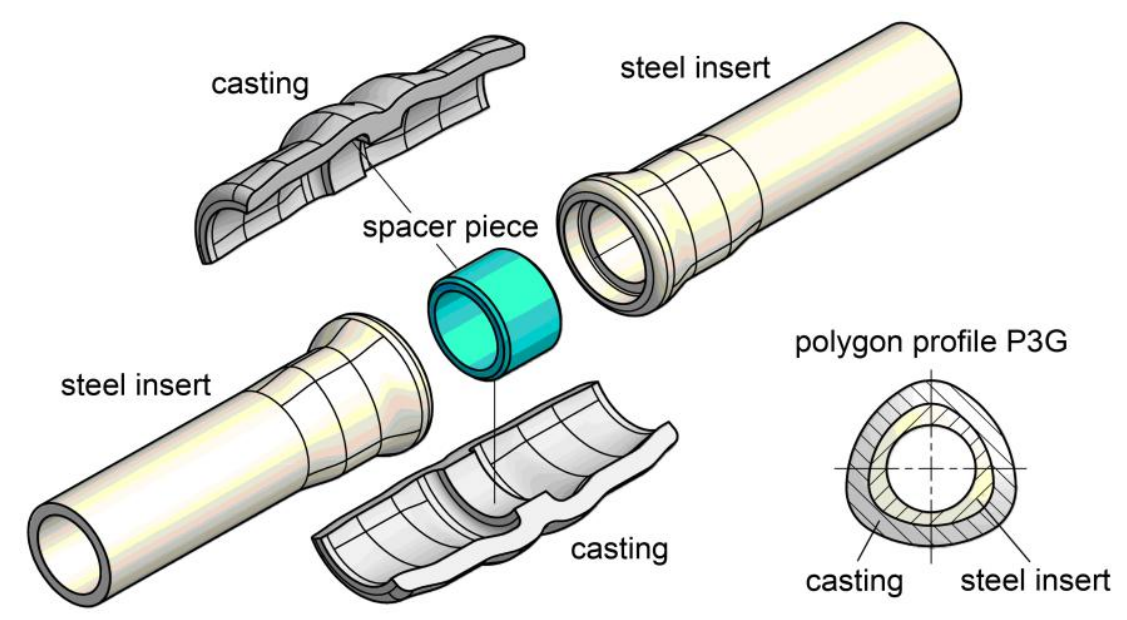

Figure 3.7 Exploded drawing of the squeeze cast demo-axial sample with a pair of inserts of shaped steel tubes $[57,58]$ 


\subsection{Casting process}

\subsubsection{Gravity die casting - rod sample}

For the gravity die casting LKR used rod steel inserts with length of $100 \mathrm{~mm}$ and diameter of $10 \mathrm{~mm}$ (Figure 3.2). The insert was coated with different materials like $\mathrm{Cu}, \mathrm{Zn}, \mathrm{Cr}-\mathrm{Ni}$. The inserts were embedded by AlSi7Mg0.3. The inserts hang in the mould which was filled with the Al alloy. We used two extra holders (see Figure 3.10) to fix the insert in the right position. The holes at the bottom of the mould were closed by AlSi7Mg0.3 inserts. The ingate is placed centrally.

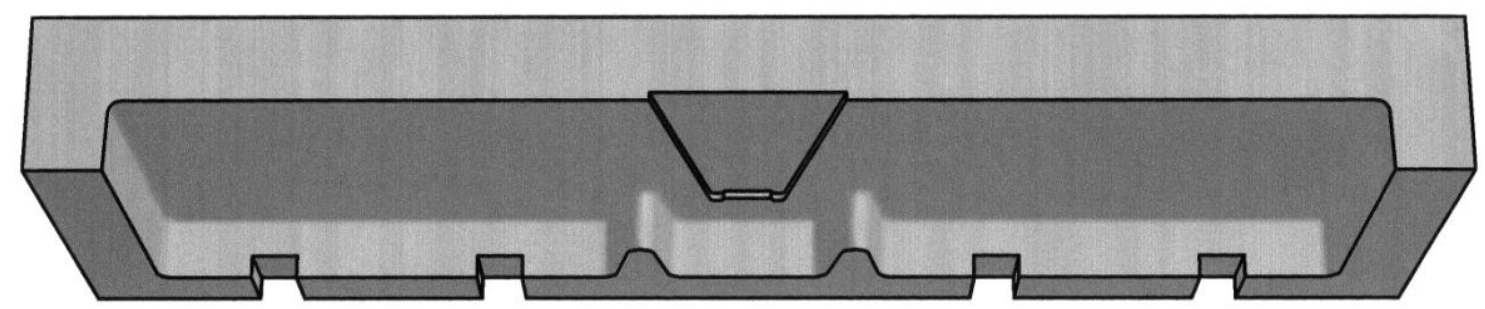

Figure 3.8 View of half of the mould - 3D [58]

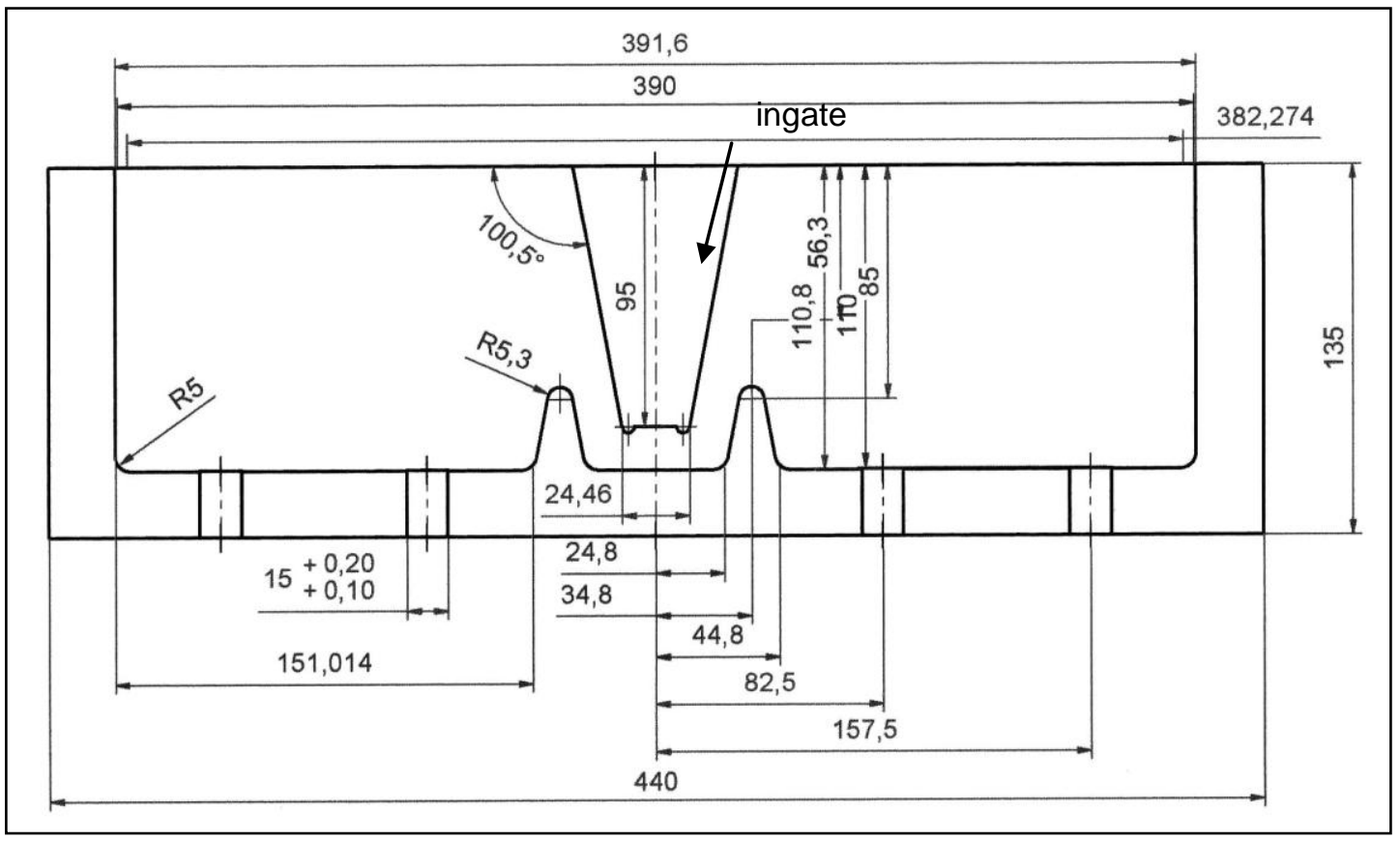

Figure 3.9 Sketch of the mould- front view with dimensioning [58] 


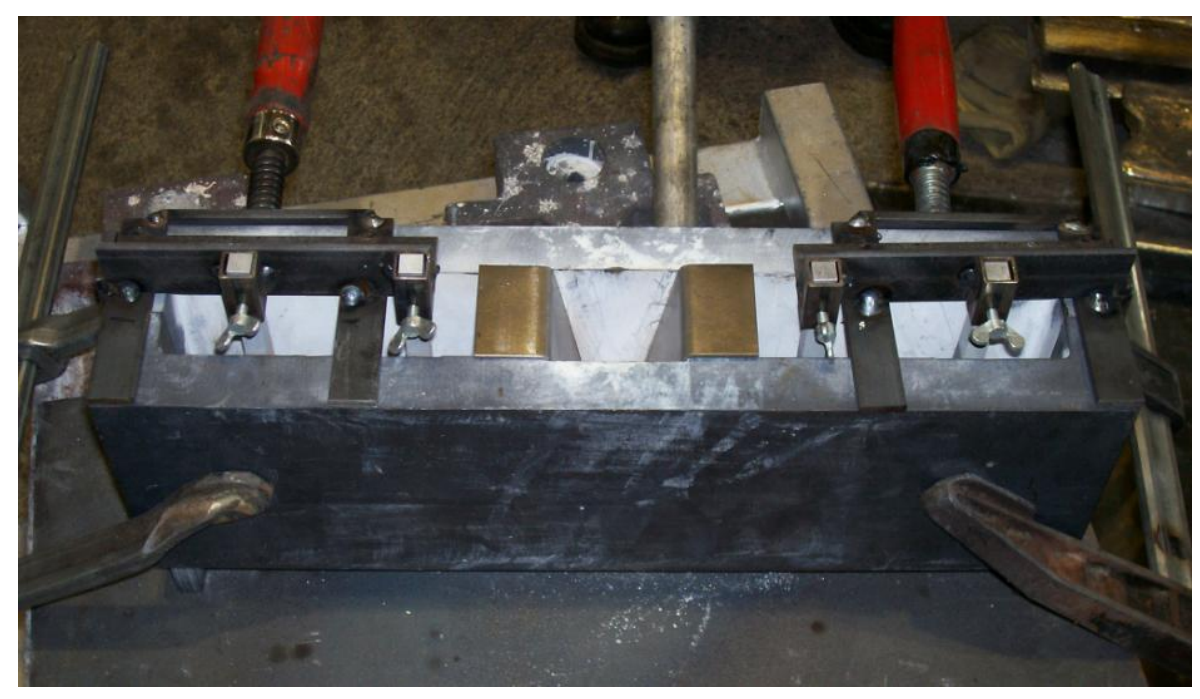

Figure 3.10 Mould construction with the joining of the rods

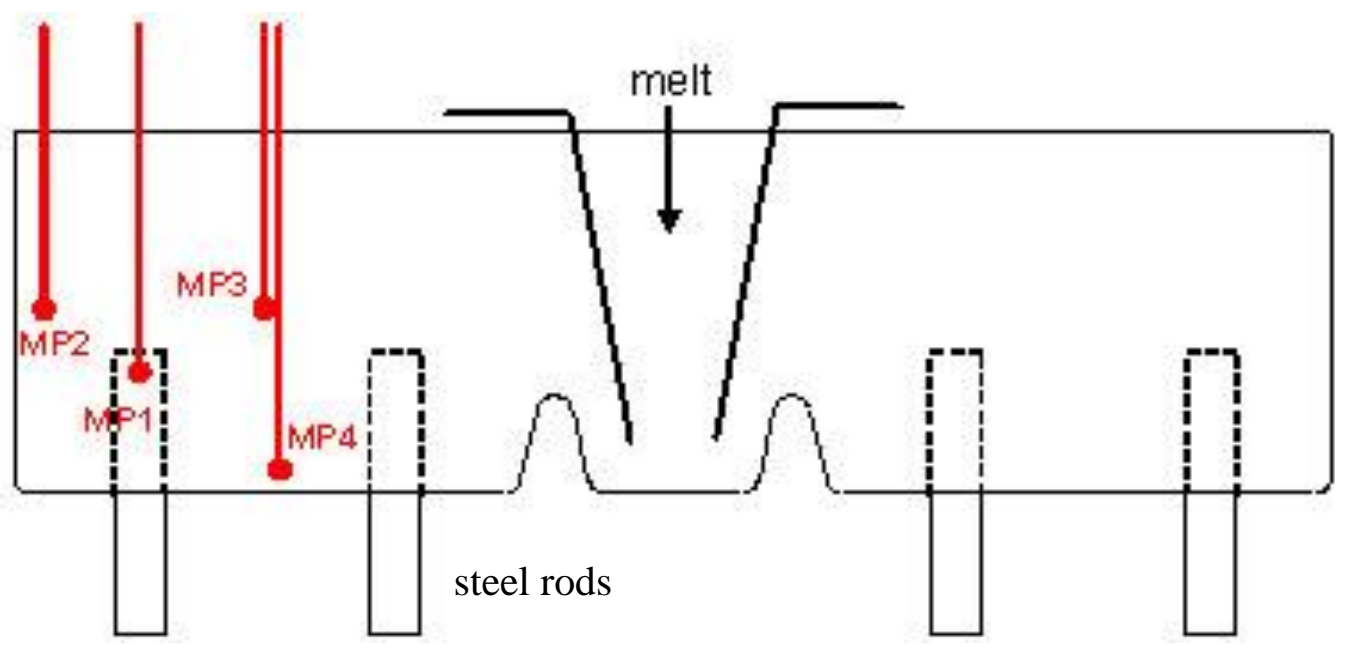

Figure 3.11 Positions of the temperature sensors - Day $1 \& 2$

Figure 3.11 shows the positions of the temperature sensors, which are fixed during the experiment in order to show the cooling curves. Sensor 1 (MP1) is fixed directly in the insert, where one little whole was drilled. Sensor 2 (MP2) shows the cooling curve on the side of the mould, where sensor 4 (MP4) shows the curve at the bottom of the mould. Sensor 3 (MP3) shows cooling curve in the middle of the mould. The next two diagrams show the results of the temperature sensors fixed at different positions of the mould (Figure 3.12/3.13). 


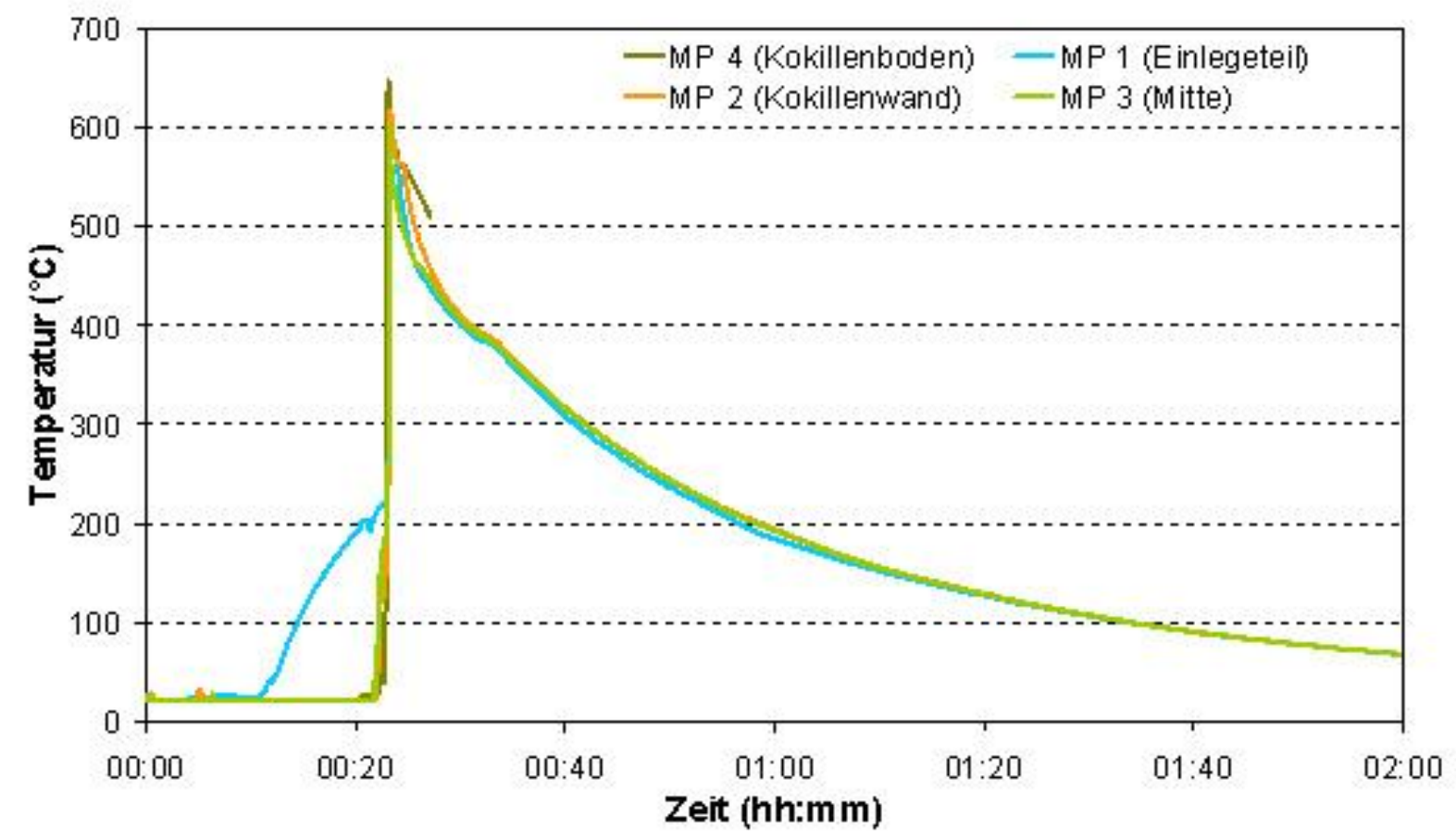

Figure 3.12 Temperature sequence (MP1 - MP4) of air cooled casting in the mould

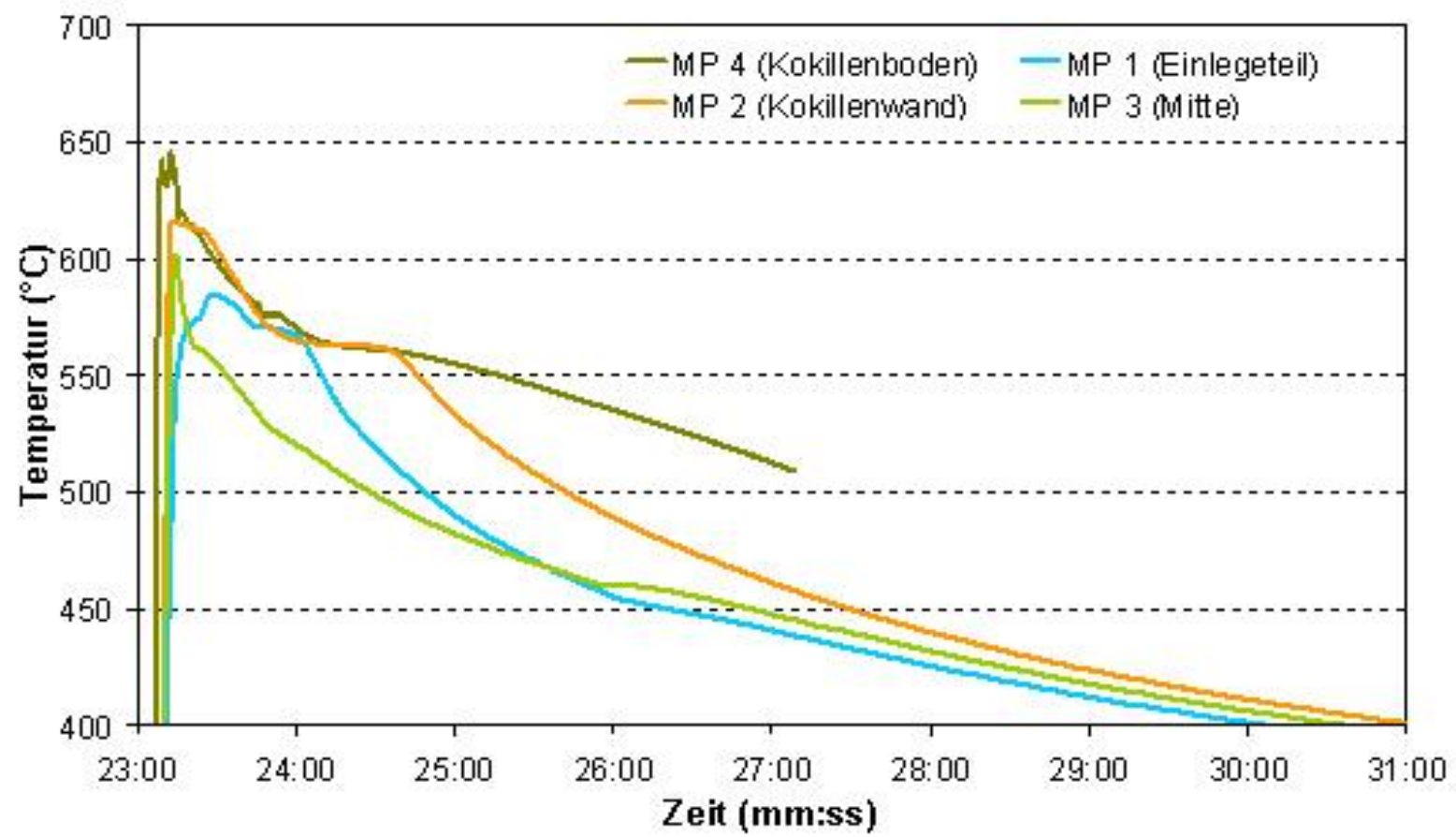

Figure 3.13 Temperature sequence $(\mathrm{MP} 1-\mathrm{MP} 4)-400^{\circ} \mathrm{C}-700^{\circ} \mathrm{C}$ during solidification 


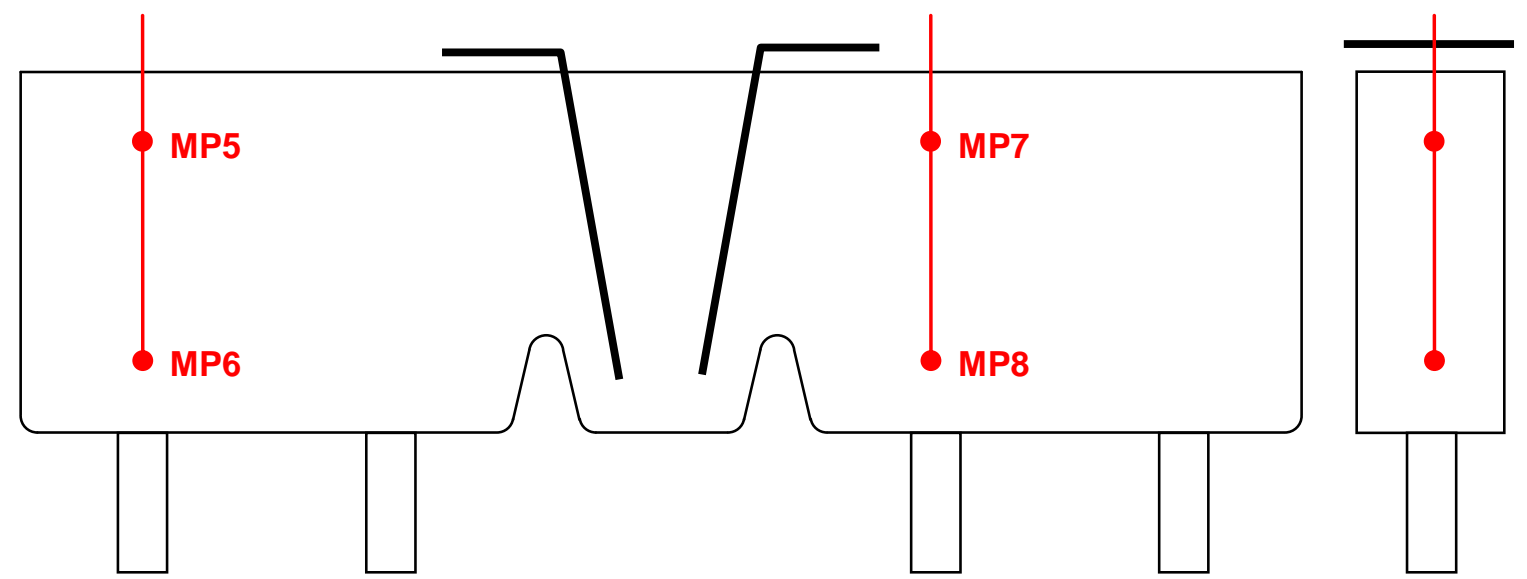

Figure 3.14 Positions of the temperature sensors - Day 3

Figure 3.14 shows the positions of the sensors during the experiment without any inserts, closed at the bottom of the mould to prevent the melt do flow out. The four sensors are to show the temperature curves of the outer (MP5 \& MP6) and inner (MP7 \& MP8) insert. Moreover, one sensor of the sensor pair was fixed at the bottom (MP6 \& MP8) of the mould and one at the top (MP5 \& MP7). The next two diagrams show the results of the temperature sensors (Figure 3.15/3.16).

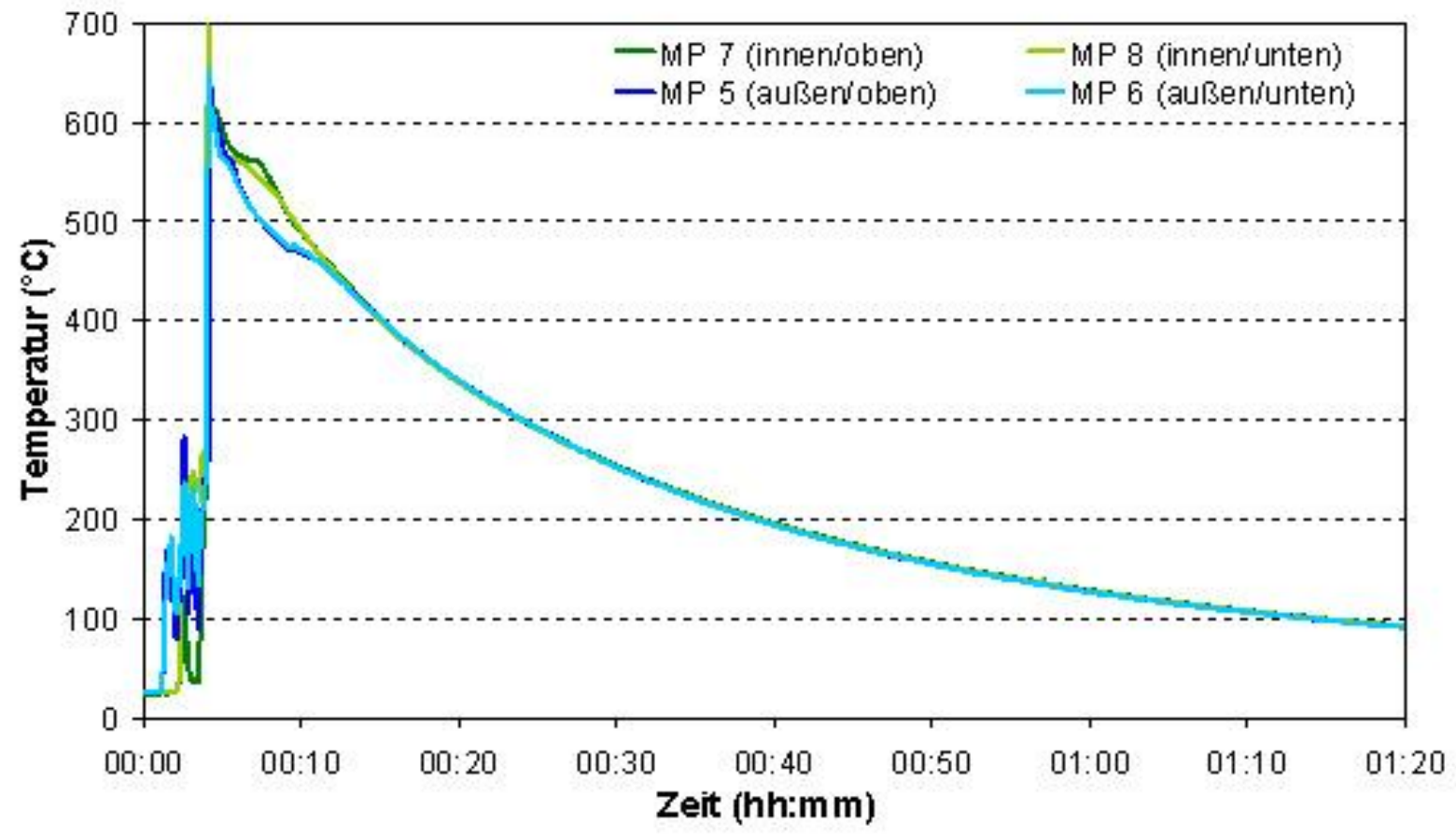

Figure 3.15 Temperature sequence (MP5 - MP8) 


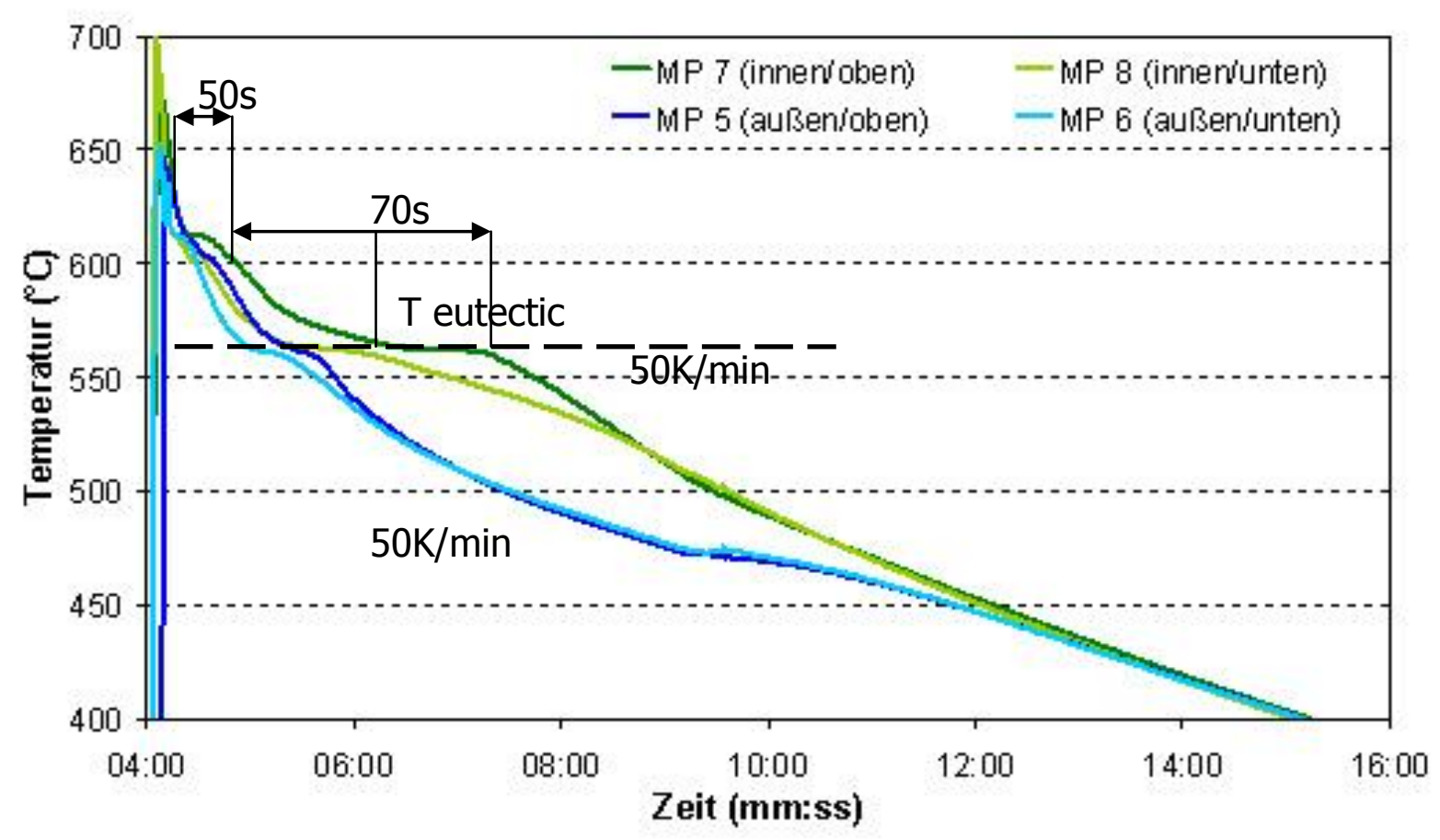

Figure 3.16 Temperature sequence (MP5 - MP8) $-400^{\circ} \mathrm{C}-700^{\circ} \mathrm{C}$

\subsubsection{Gravity die casting - cube sample}

Cube insert of steel St37 were used with the length of $23.4 \mathrm{~mm}$ fixed in the middle of the mould and embedded in two different alloys: Al (99.8\%) and AlSi7Mg0.3 (see Figure 3.4 a). The volume ratio of $\mathrm{Fe}$ to Al was 1:25. The steel cube insert was etched for $45 \mathrm{~s}$ in $10 \% \mathrm{HCL}$ and afterwards cleaned with isopropanol and dried with hot air. During the experiment we measure the temperature at the wall of the mould, in the middle between the mould wall and the insert, and inside the insert (see Figure $3.4 \mathrm{~b}$ ). The mould was kept at different temperatures of $700^{\circ} \mathrm{C}, 100^{\circ} \mathrm{C}$ and RT.

The diagrams show the cooling of the mould wall (Kanal 1 ) is faster then inside the insert (Kanal 3). Due to cooling from outside to inner side should be no cracks.

Sensors positions:

Kanal 1 - inside the insert

Kanal 2 - in the middle between the mould wall and insert

Kanal 3 - mould wall 


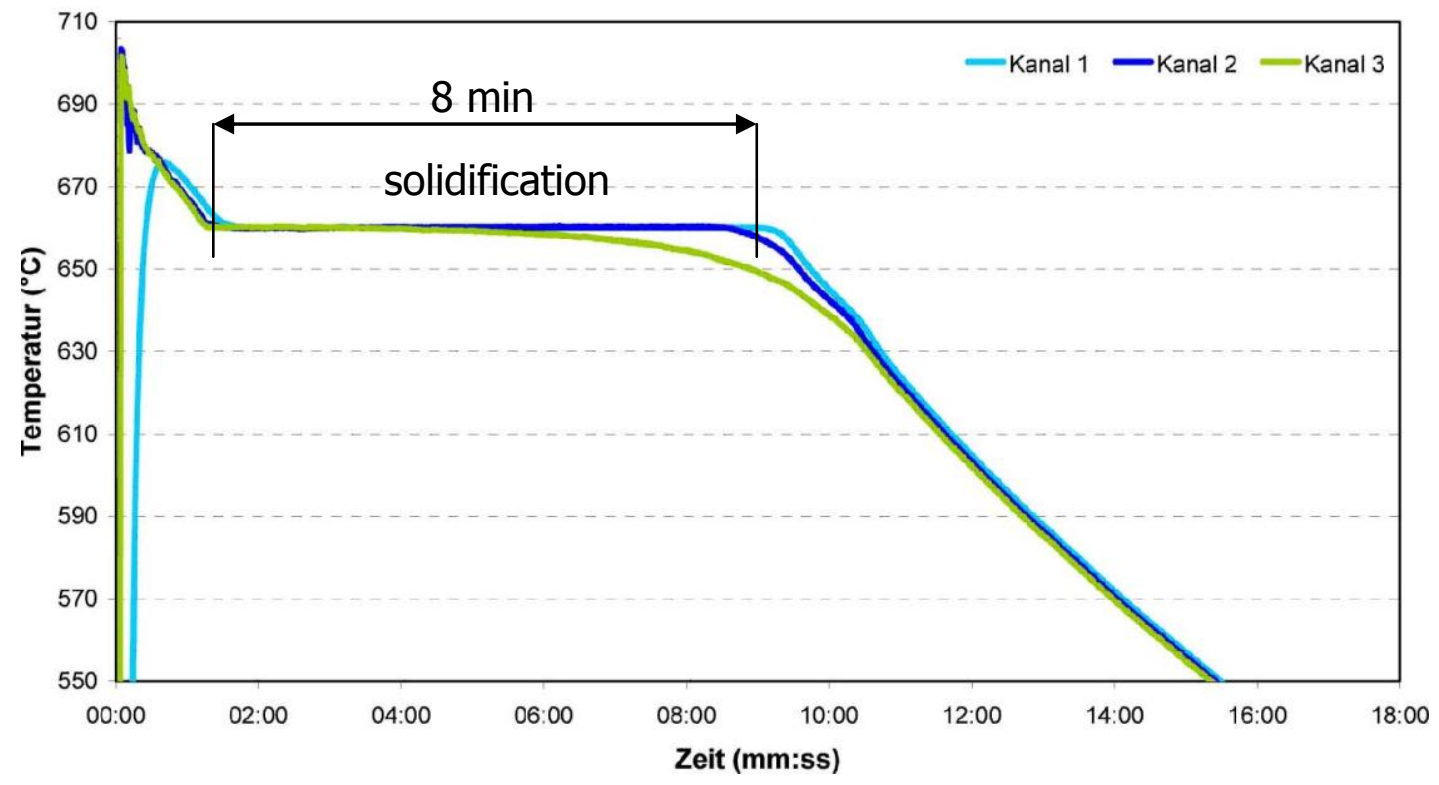

Figure 3.17 Cooling diagram of $\mathrm{Al}(99.8 \%)$, mould at $700^{\circ} \mathrm{C}$

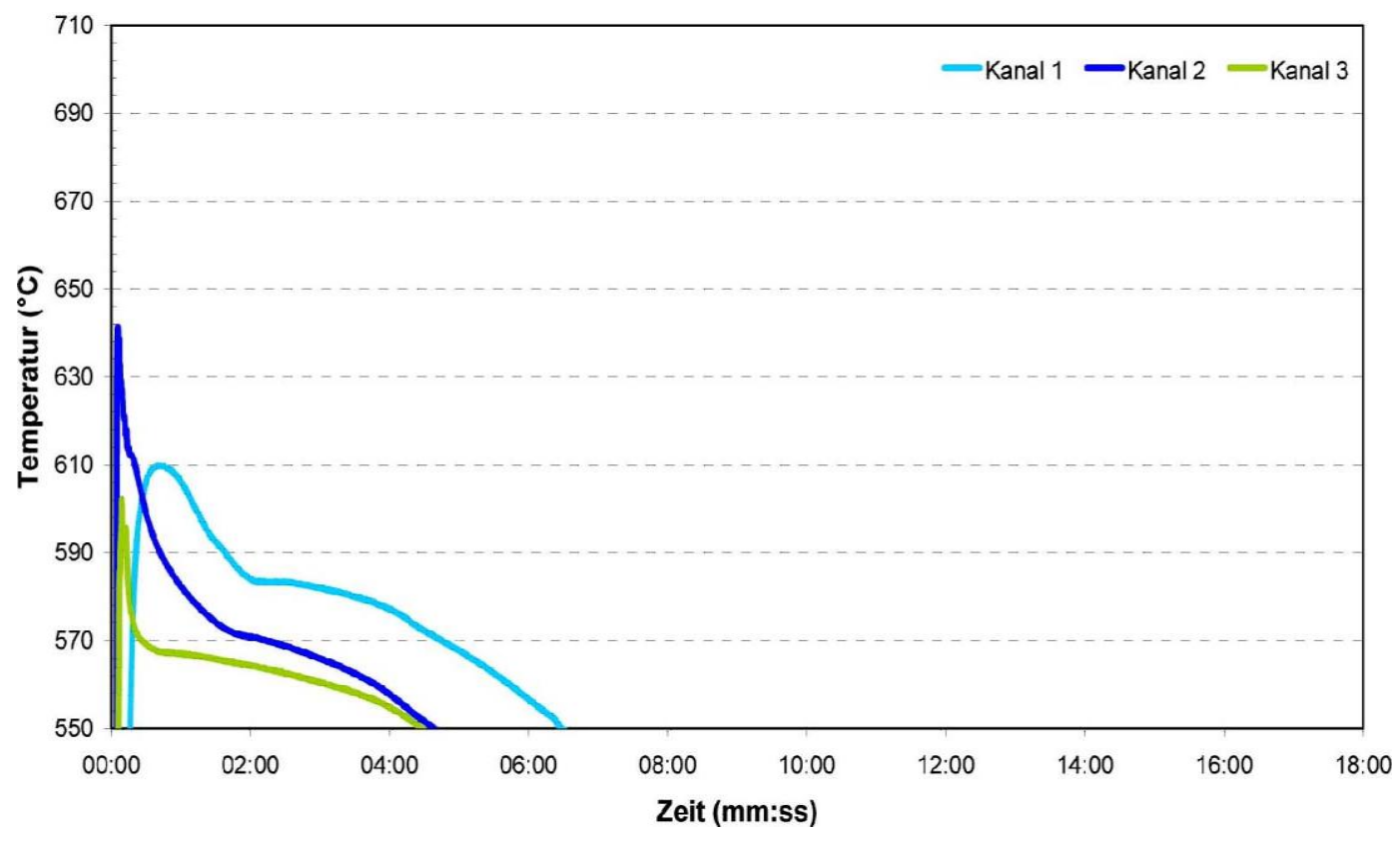

Figure 3.18 Cooling diagram of pure $\mathrm{Al}(99.8 \%)$, mould at $100^{\circ} \mathrm{C}$ 


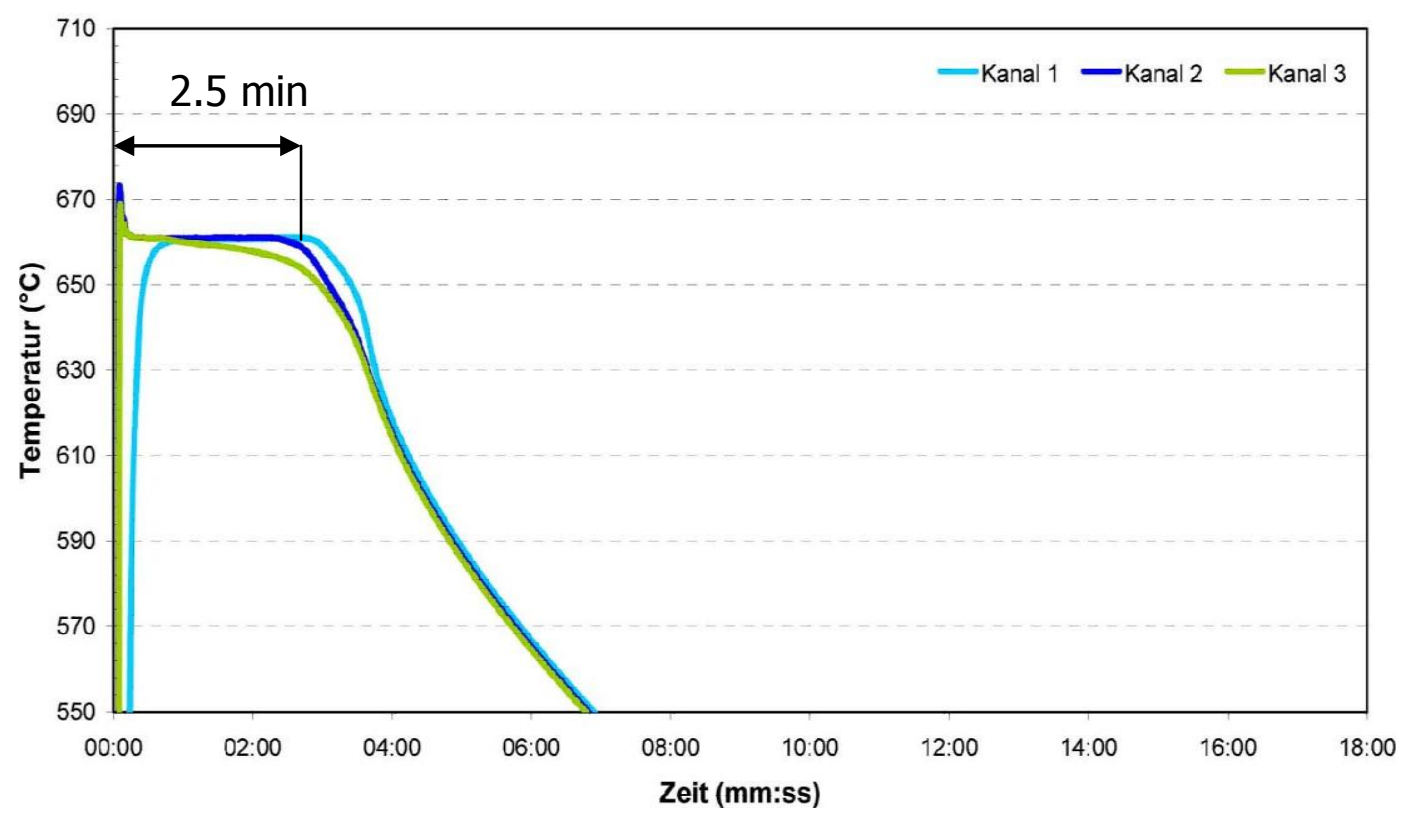

Figure 3.19 Cooling diagram of pure Al $(99.8 \%)$, mould at RT

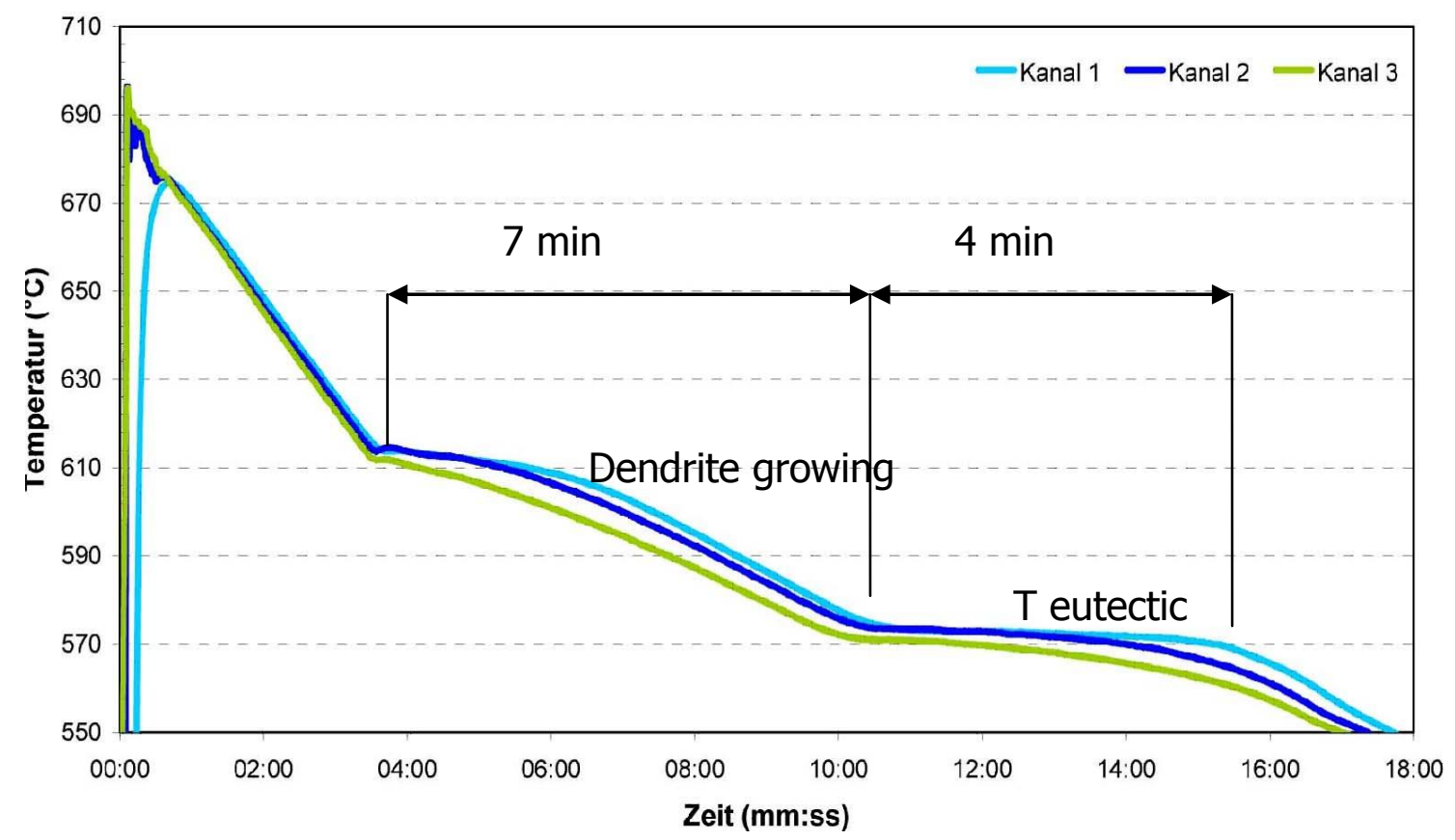

Figure 3.20 Cooling diagram of AlSi7Mg0.3, mould at $700^{\circ} \mathrm{C}$ 


\subsubsection{Low pressure die casting}

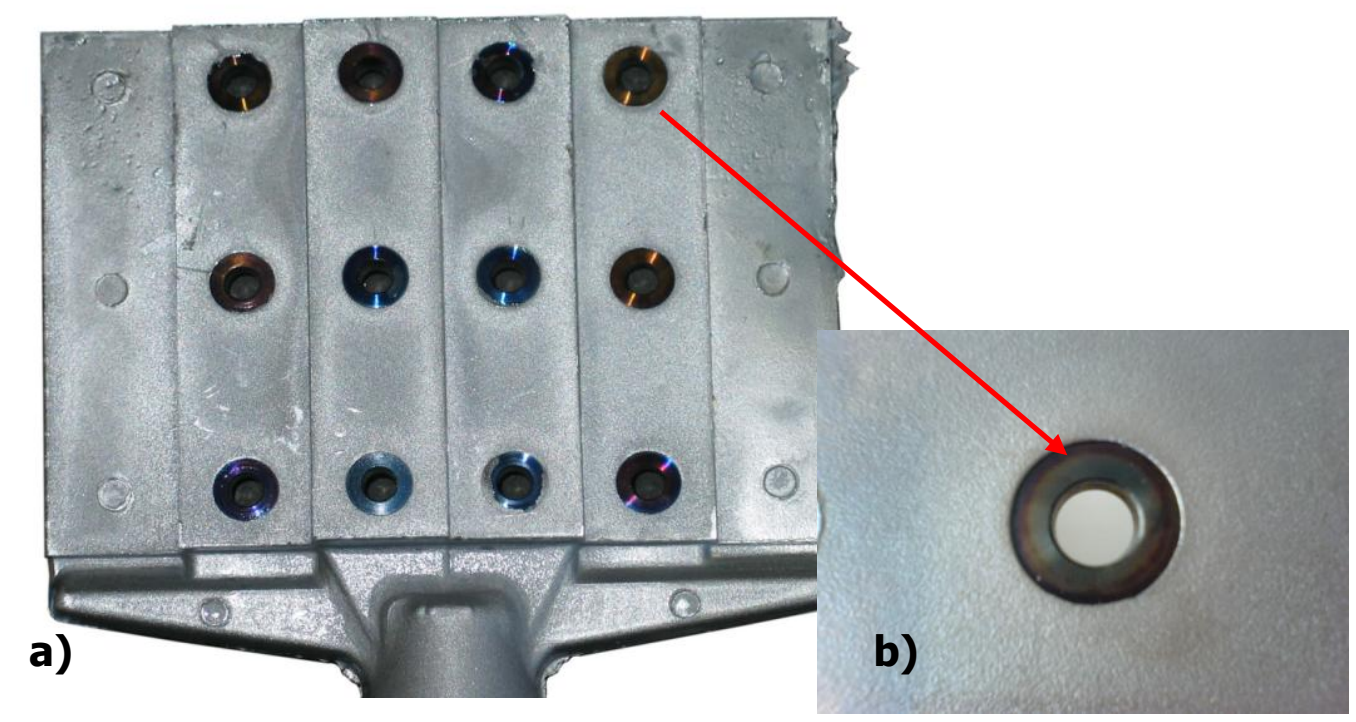

Figure 3.21 Low pressure die casting: a) compound casting, b) steel insert

Step sample has been produced from AlSi7Mg0.3 alloy by low pressure die casting (see Figure 3.21). One part of the samples was removed from the mould as soon as possible and quenched in water. Another part of the samples was removed from the mould as soon as possible and cooled down in air.
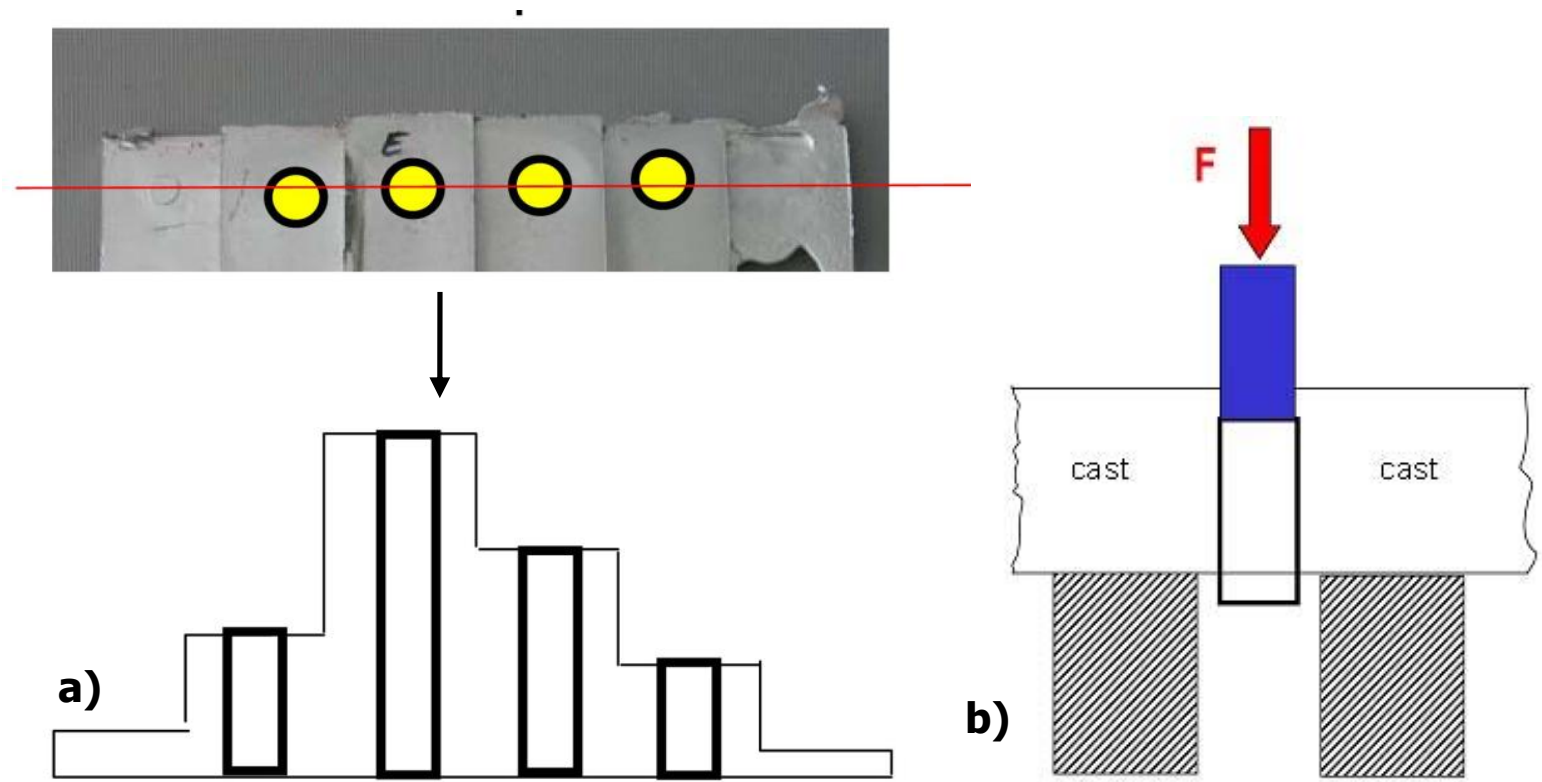

Figure 3.22 a) cross section of the sample, b) characterization of the mechanical strength by pull out test 


\subsubsection{Squeeze casting}

As already mentioned, the demo-axial sample has been manufactured using squeeze casting. Figure 3.23 a) shows the steel inserts positioned in the casting mould. Figure (b) show steel inserts (top) and a finished casting including the casting gate and four overflows (bottom). The four overflows are later broken off and the casting gate is machined off. Figure (c) shows a cross section of the sample.

After casting, the samples were removed from the mould as early as possible and immediately quenched in water. No further heat treatment was performed, so that the residual stresses that develop during the quenching process persist and determine the frictional connection of the structure [57].

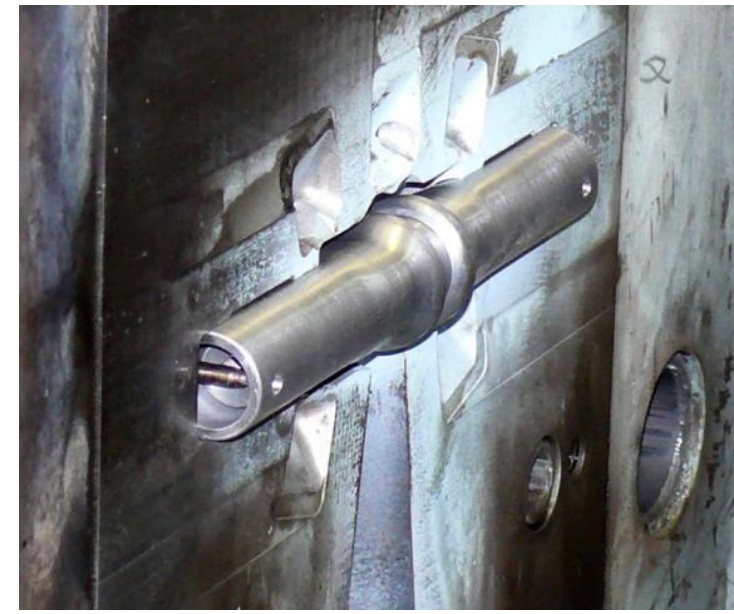

a)

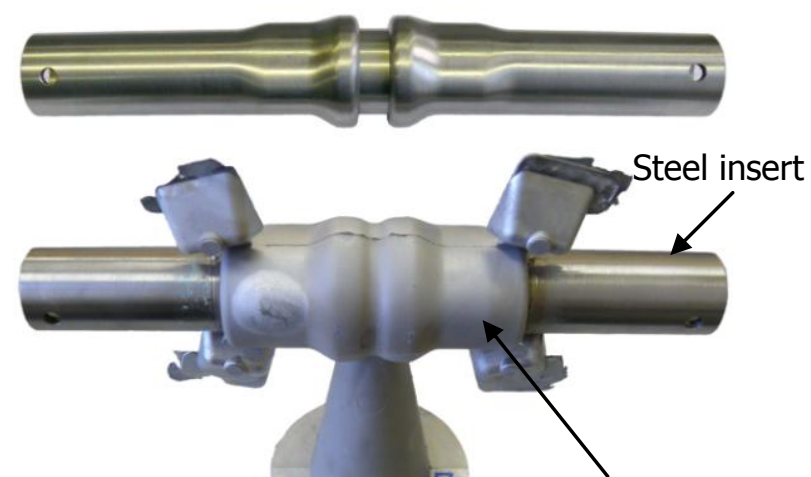

Aluminium casting b)

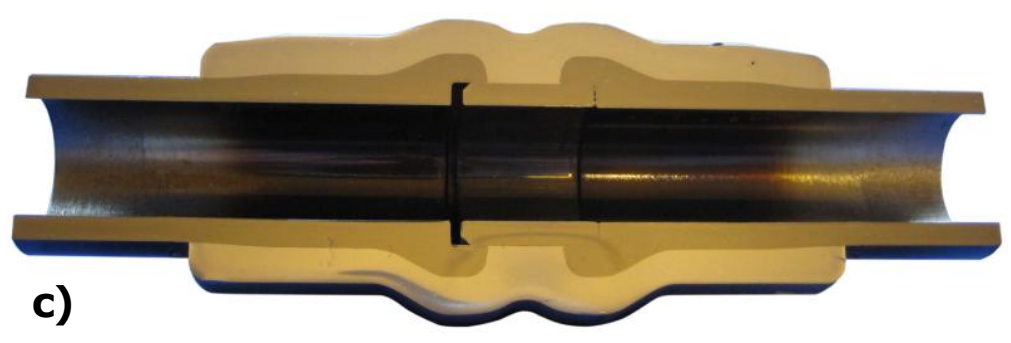

Figure 3.23 Demo-axial sample as a compound casting, a) Steel insert positioned in a squeeze casting mould [58], b) Steel insert (top) and compound casting [58], c) Cross section of the sample [57]

For the cold drawn steel inserts made of C45E steel with yield strength of 660MPa. Heat flux from one material into another produces a thermal gradient at the interface as shown in Figure 3.24 a). The quotient of heat flux and thermal resistance represents the thermal contact conductance of the interface. The figure shows contact conductance at the steel-aluminium interface as a function of macroscopical gap width. 


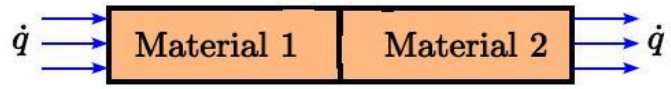

a)

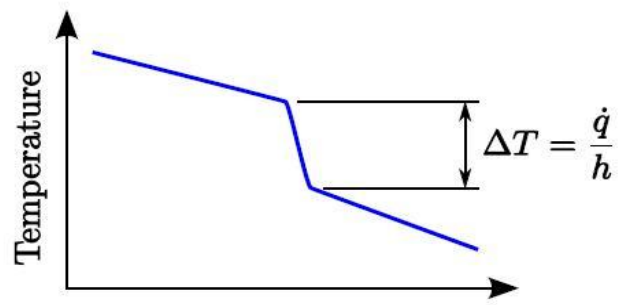

Distance

The mal Contact Conductance $\mathrm{h}\left[\mathrm{W} / \mathrm{m}^{\mathrm{I}} \mathrm{K}\right]$

15020050

b) Gap width $[\mu \mathrm{m}]$

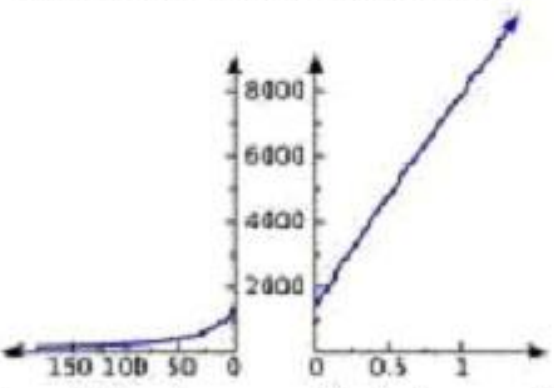

Contact presure [MPa]

Figure 3.24 [58] a) $\Delta \mathrm{T}$-curve of AlSi7Mg0.3 during quenching and in the natural aged condition, b) Differential linear coefficient of thermal expansion of AISi7Mg0.3 and C45E [59]

\subsection{Thermal treatments}

Different thermal treatments of the materials were carried out (Figure 3.25). The aging was carried out in a Linn High Therm furnace 70.26 at 165,250 and $350^{\circ} \mathrm{C}$ followed by air cooling. Thermal treatment was performed at the step and demoaxial samples (AISi7Mg0.3).

\begin{tabular}{|l|c|}
\hline \multicolumn{1}{|c|}{ Sample } & Heat treatments \\
\hline & \\
\cline { 1 - 1 } Step sample & $165^{\circ} \mathrm{C} / 2.5 \mathrm{~h}+13 \mathrm{~h}$ \\
\cline { 1 - 1 } $250^{\circ} \mathrm{C} / 5 \mathrm{~h}$ \\
\cline { 1 - 1 } $350^{\circ} \mathrm{C} / 2 \mathrm{~h}$ \\
\hline
\end{tabular}

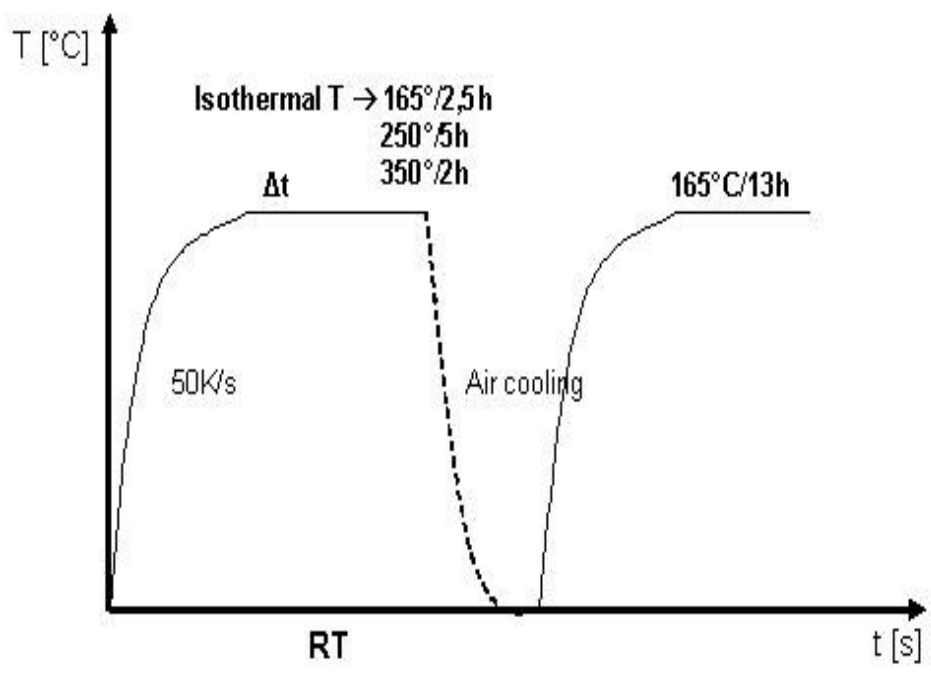

Figure 3.25 Thermal treatment of AlSi7Mg0 0.3 with heating rate of $50 \mathrm{~K} / \mathrm{s}$ and air cooling 


\subsection{Test methods}

\subsubsection{Temperature measurements}

To measure the cooling rate we used the whole step sample (Sample \#4). The sample was heated till $510-530^{\circ} \mathrm{C}$ for $15 \mathrm{~min}$ and water quenched within a few seconds. The casting was immersed into the water with the flat bottom perpendicular to the water surface. To measure the cooling rate we used special equipment with 10 thermocouples fixed on the surface and inside the sample ( $2 \mathrm{~mm}$ deep), see Figure 3.26. Two thermocouples (\#3 and 6) were fixed on the surface and the rest inside the sample. Sample $\mathrm{Nr} 1,3,7,8$ and sample 9 had been investigated. The results of the temperature measurement show Figure 4.1.

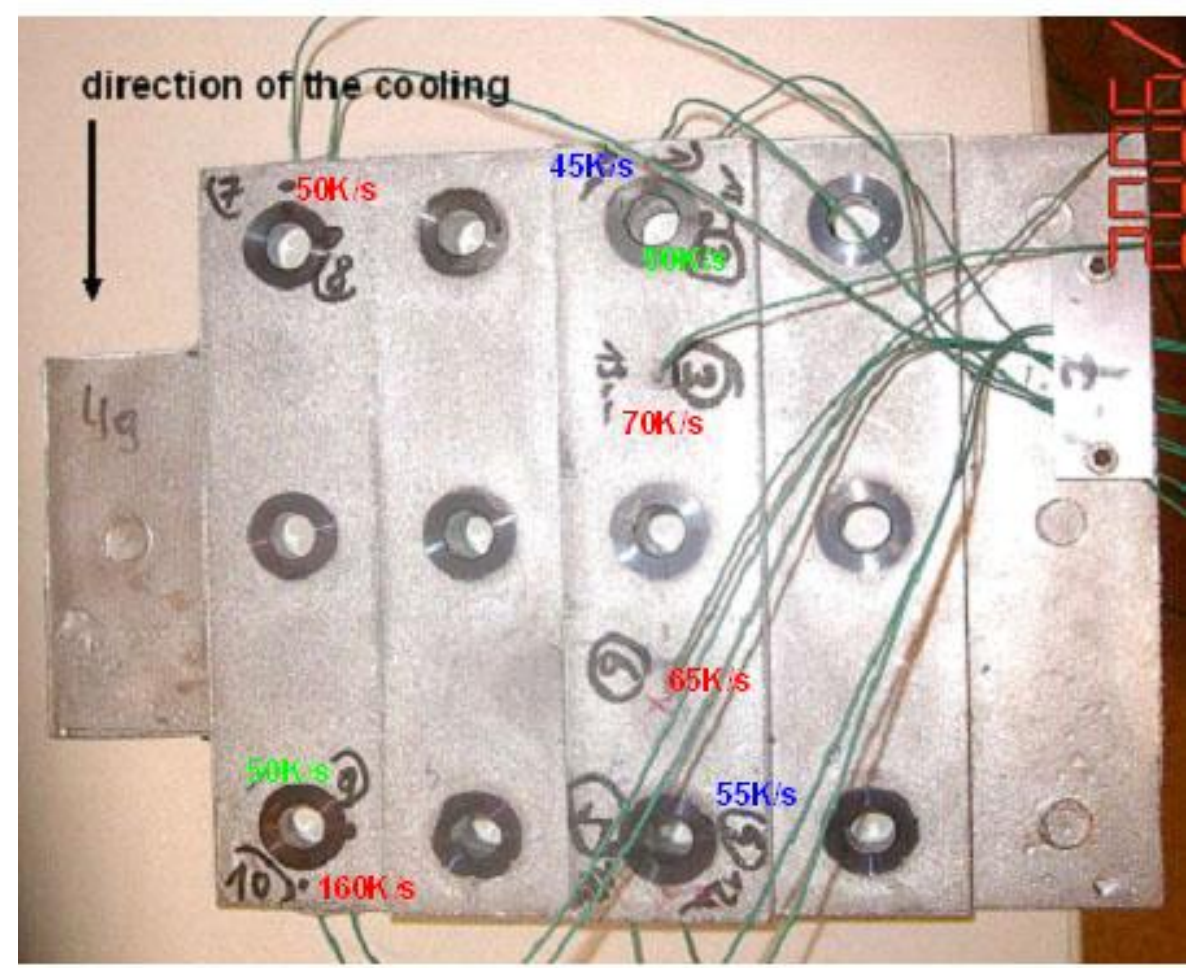

Figure 3.26 View of the low pressure die casting with different step heights $(10,15,20,25 \mathrm{~mm})$ with steel ring inserts and mounted thermocouples 


\subsubsection{Microstructure analysis}

Samples of aluminium alloys were embedded in epoxy resin for around 24 hours. The materials were ground with 320, 500, 1000, 2400 and 4200 Strucers SiC paper for grinding with water as a coolant with rotating speed of 300RPM. After grinding the samples were polished with DP-diamond paste of 6, 3 and $1 \mu \mathrm{m}$. Polishing with MgO was performed at the end, as a final polishing.

Light optical microscopy (LOM) was performed by means of a Zeiss Axioplan microscope with digital imaging system. Optical zoom between 2.5 and 100x were available in this instrument. Light optical microscopy was used to characterize the micro-structure of the casting and of the interface between aluminium and steel insert.

Scanning electron microscopy (SEM) was carried out by means of Philips XL-30 scanning electron microscope using a beam of $15 \mathrm{kV}$. To observe the interface back scattered electron (BSE) mode has been used. Etching was performed in order to produce good contrast for the investigations.

The aim of the SEM analysis was to look for the interface reaction phases, porosity, cracks and the bonding between Al and steel inserts.

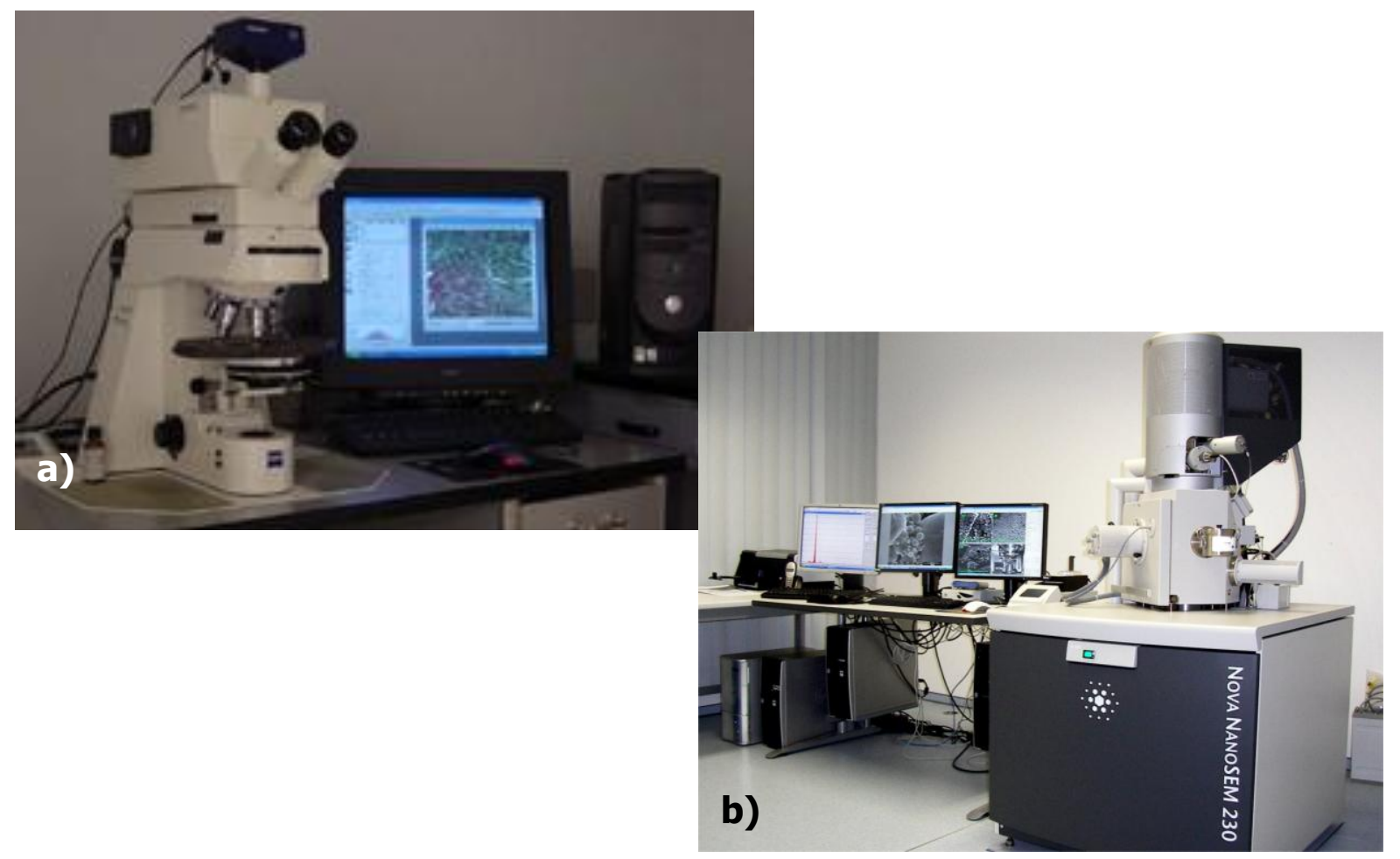

Figure 3.27 Instruments used for surface analysis:

a) Light Optical Microscopy, b) Scanning Electron Microscopy 


\subsubsection{Hardness}

Samples of identical shapes used for differential scanning calorimetry and dilatometric measurements were used to perform hardness tests by means of an Universal Tester Model M1C010 provided by Emco Test.

Hardness measurements are widely used for the quality control of materials because they are quick and considered to be non-destructive tests when the marks or indentations produced by the test are in placed low stress areas.

The Brinell hardness was measured using load of $10 \mathrm{~kg}$ and $1 \mathrm{~mm}$ ball. The load was applied for 10 to 15 seconds. The diameter of the indentation left in the test material is measured with a low powered microscope. Before the measurements the samples were polished. The Brinell value at each state was obtained by an average of at least ten measurements.

The Brinell hardness number is calculated by dividing the load applied by the surface area of the indentation. The samples were tested in different thermal conditions.

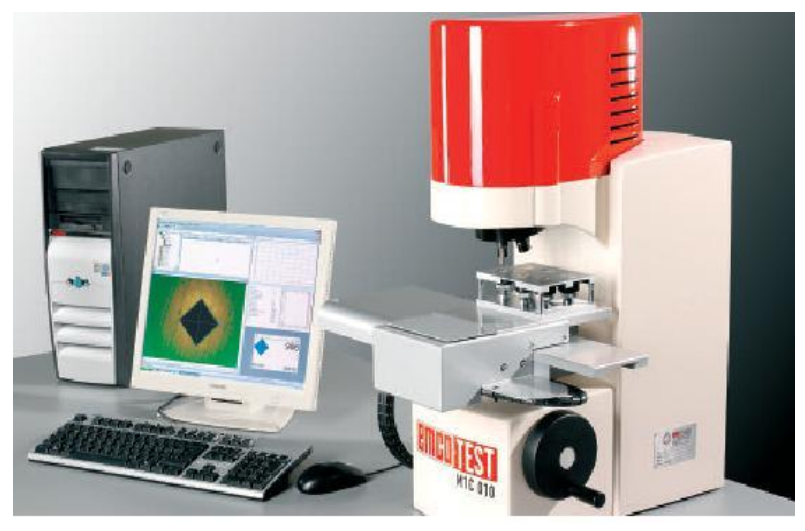

Figure 3.28 Device for hardness measurements

\subsubsection{Thermal analysis $[60,61,62]$}

\subsubsection{Thermal expansion measurements}

Thermalmechanical analysis (TMA) is one of the groups of techniques termed thermal analysis (TA). Is the measurement of a change of a dimension or a mechanical property of the sample while it is subjected to a temperature regime.

For thermal-mechanical analysis we used thermal mechanical equipment TMA 2940 CE (Figure 3.29). TMA instrument monitors dimensional changes as a function of temperature. This allows determination of softening points and thermal expansion coefficients from around -70 to $+1000^{\circ} \mathrm{C}$.

The heart of the instrument is a moveable-core linear variable differential transformer (LVDT), the output of which is proportional to the linear displacement of the core caused by changes in sample dimensions. 
The core itself is part of a quartz probe that contacts the sample. In the TMA, the sample is positioned above LVDT, on the quartz stage and the moveable probe was placed on the top of the sample (see Figure 3.29). The quartz probe with low coefficient of thermal expansion of about $0.5 \mathrm{ppm} / \mathrm{K}$ transmits changes in the length of the specimen to the transducer (LVDT) with resolution of $0.1 \mu \mathrm{m}$.

Temperature control of the sample is achieved by programming a low mass furnace, with heating rates between 0.01 and $200 \mathrm{~K} / \mathrm{min}$ that is automatically lowered to surround the sample stage and the probe, but maximum $20 \mathrm{~K} / \mathrm{min}$ were applied.

The sample temperature is measured using a thermocouple, positioned close to the sample. An optional cooling device placed around the furnace core accommodates programmed cooling and subambient operation. The furnace is filled with nitrogen during the experiments $(100 \mathrm{ml} / \mathrm{min})$. Force applied to the sample $(0.001$ to $1 \mathrm{~N})$ is generated and controlled by an electromechanical coil. The force can be held constant or varied during an experiment. The exerted pressure by the probe, with a diameter of $3 \mathrm{~mm}$, results in a stress of $7 \mathrm{kPa}$.
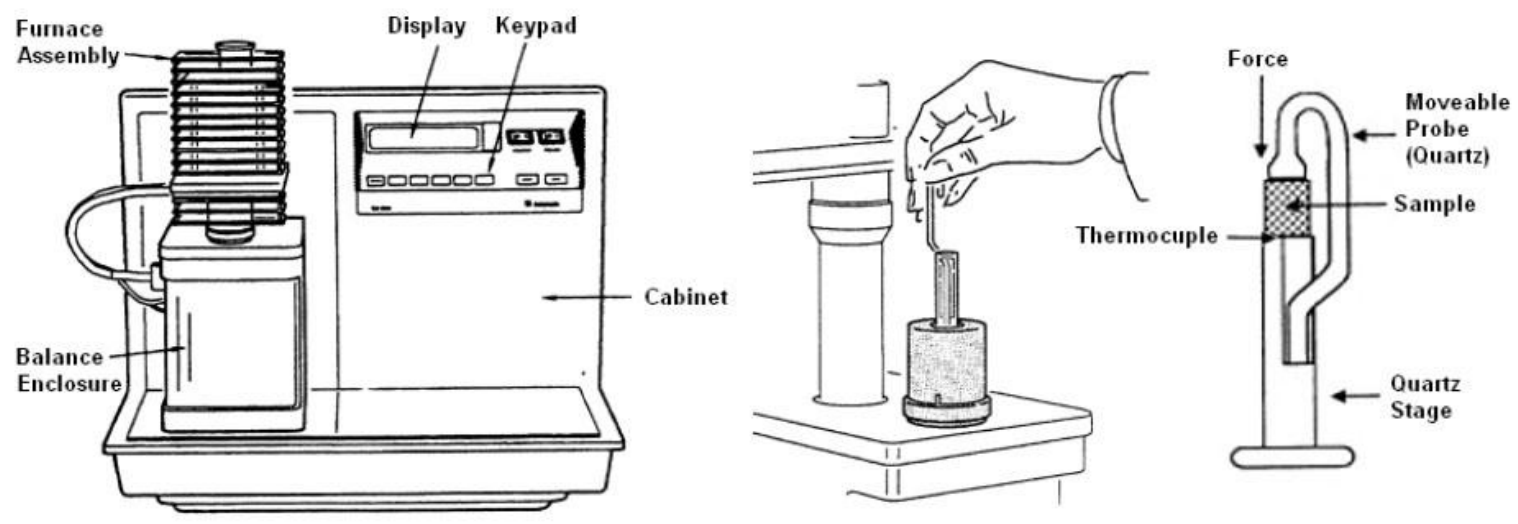

Figure 3.29 TMA 2940 according to TI instruction

Dilatometric tests were carried out on TMA 2940 CE thermal mechanical analysis equipment (TA Instruments). Samples of identical shapes $(5 \times 2 \times 15 \mathrm{~mm})$ were used for dilatometric measurements. The samples from the top and bottom were ground and polished to obtain parallel surfaces for the measurement.

The expansion $(\Delta \mathrm{l})$ of the step cast sample and step sample after heating till $165^{\circ} \mathrm{C}$ for $2.5 \mathrm{~h}$ were measured between $\mathrm{RT}$ and $540^{\circ} \mathrm{C}$ with the heating rate of $5 \mathrm{~K} / \mathrm{min}$ and cooling rate of $10 \mathrm{~K} / \mathrm{min}$ in a nitrogen atmosphere (see Figure 3.30).

The CTE curve was only calculated $10 \mathrm{~K}$ above RT until 10K below maximum temperature to avoid smoothing errors. 


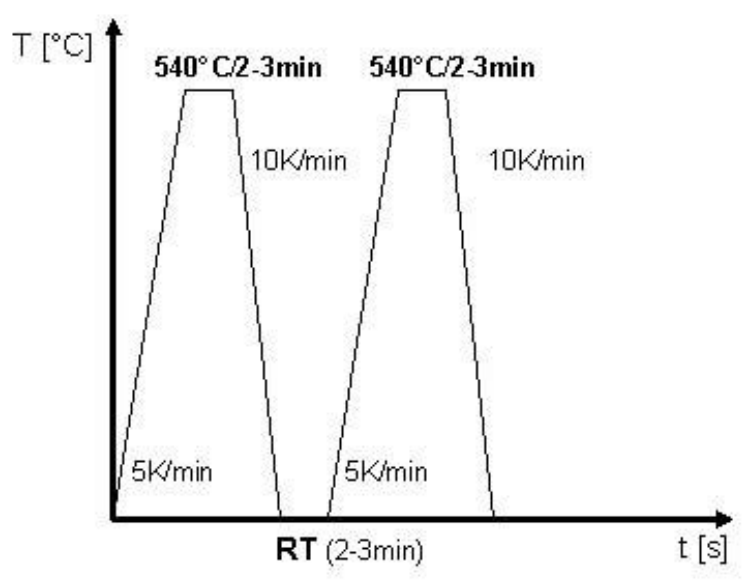

Figure 3.30 Heat treatment of the step sample (AISi7Mg0.3)

Different heat treatments were applied on AlSi7Mg0.3 alloy of the step cast sample. The sample was heated to $400^{\circ} \mathrm{C}$ and hold for 4 hours, than cooled down with 20K/min (Figure 3.31).

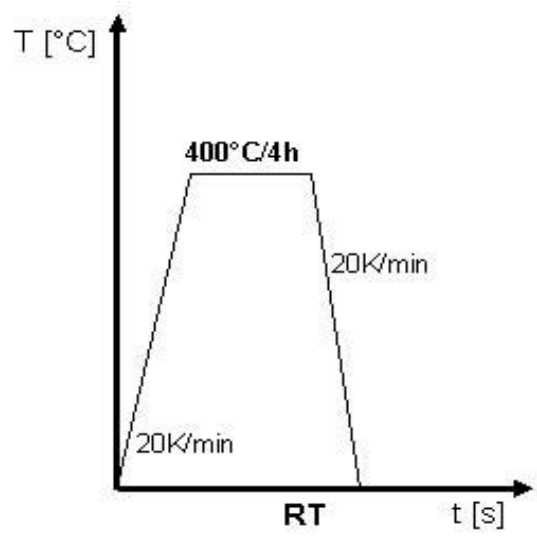

Figure 3.31 Heat treatment of AlSi7Mg from the step cast sample

Isothermal expansion measurements were carried out on different alloys: Al, AlSi7Mg0.3 by means of a Bähr dilatometry. For the first measurements we used specimens from the step sample in cast condition, heated the sample to different temperatures (see Figure 3.32) with heating rate of $50 \mathrm{~K} / \mathrm{s}$ and cooling rate of $20 \mathrm{~K} / \mathrm{min}$.

Sample of pure Al (99.8\%) was heated with heating rate of $50 \mathrm{~K} / \mathrm{s}$ till $400^{\circ} \mathrm{C}$ and held for 4 hours. Afterwards with the same heating rate heated up to $540^{\circ} \mathrm{C}$ and held for an hour and cooled at the rate of $20 \mathrm{~K} / \mathrm{min}$ (see Figure 3.33). 

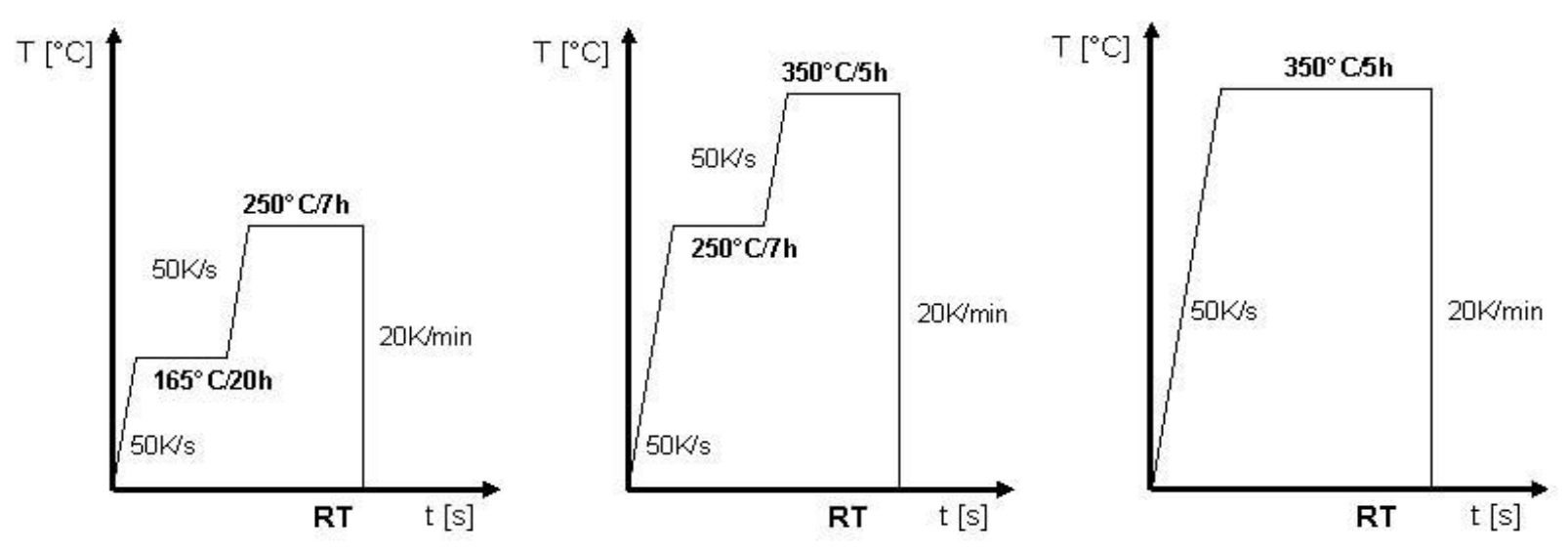

Figure 3.32 Temperature-Time curves of AISi7Mg0.3 of Bähr dilatometry

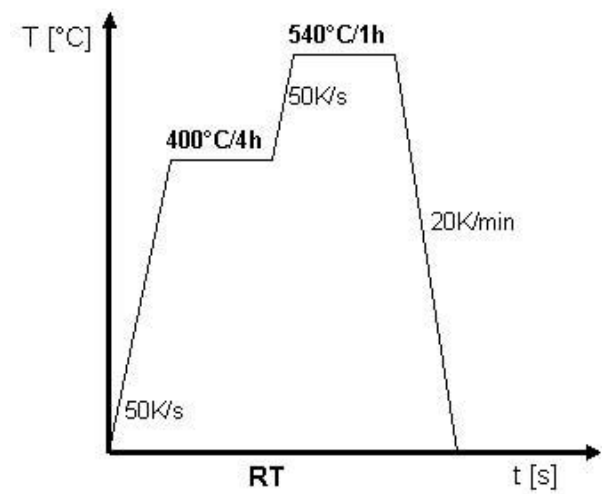

Figure 3.33 Bähr dilatometry measurement of pure aluminium (99.8\%)

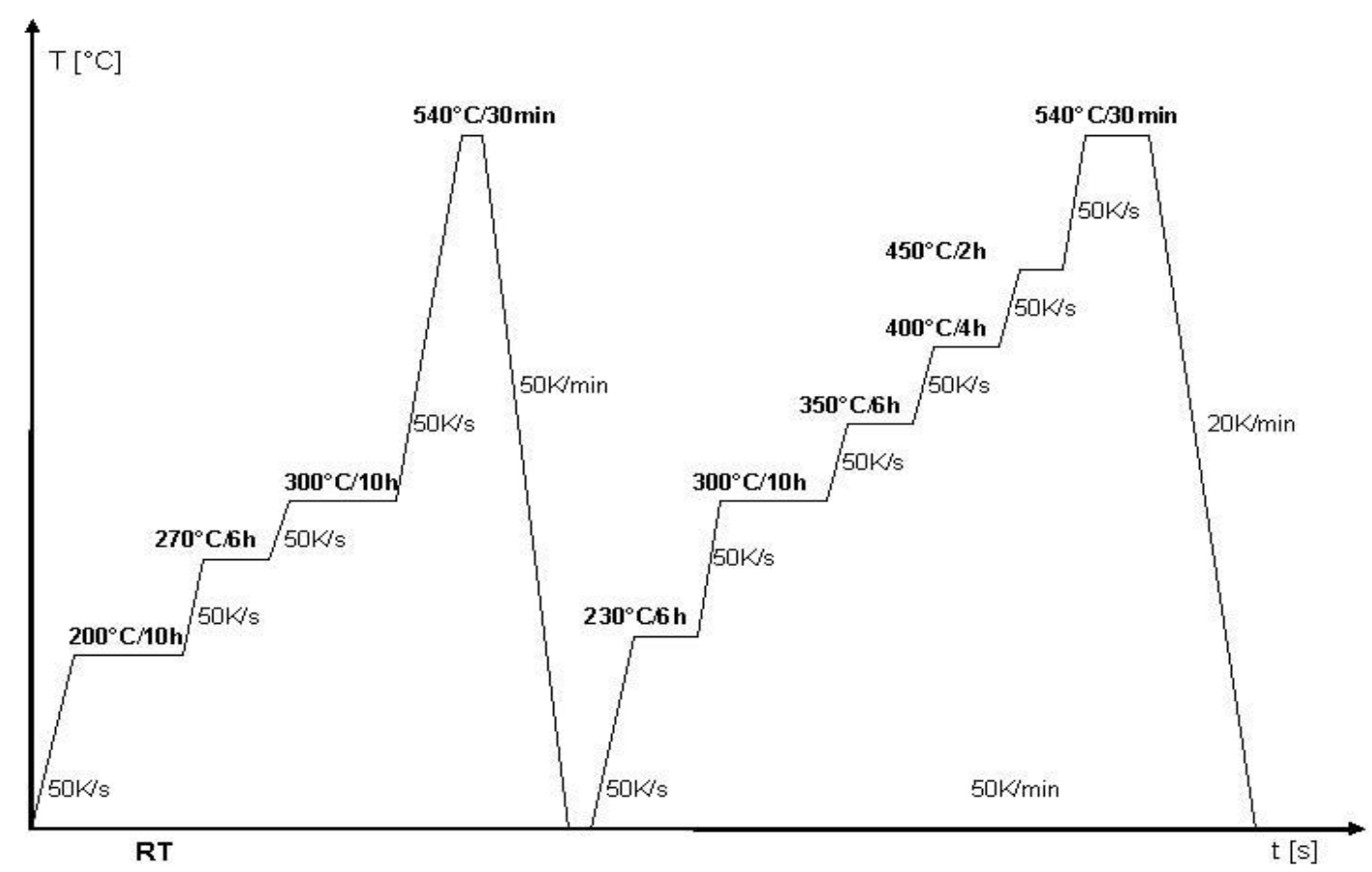

Figure 3.34 Bähr dilatometry measurements of AISi7Mg from the step cast sample S 20 (Test 1) 


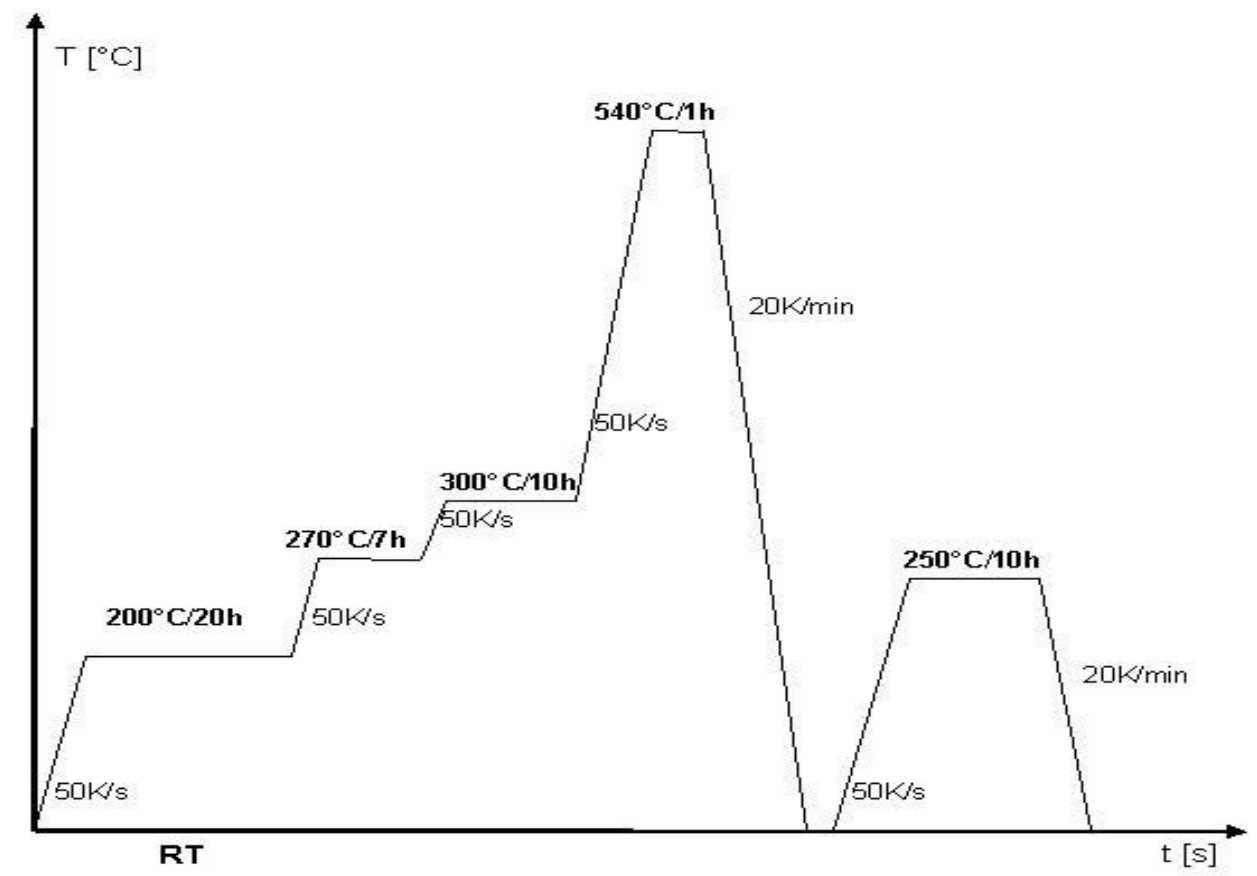

Figure 3.35 Test 2 - Measurement of S20 after Test 1

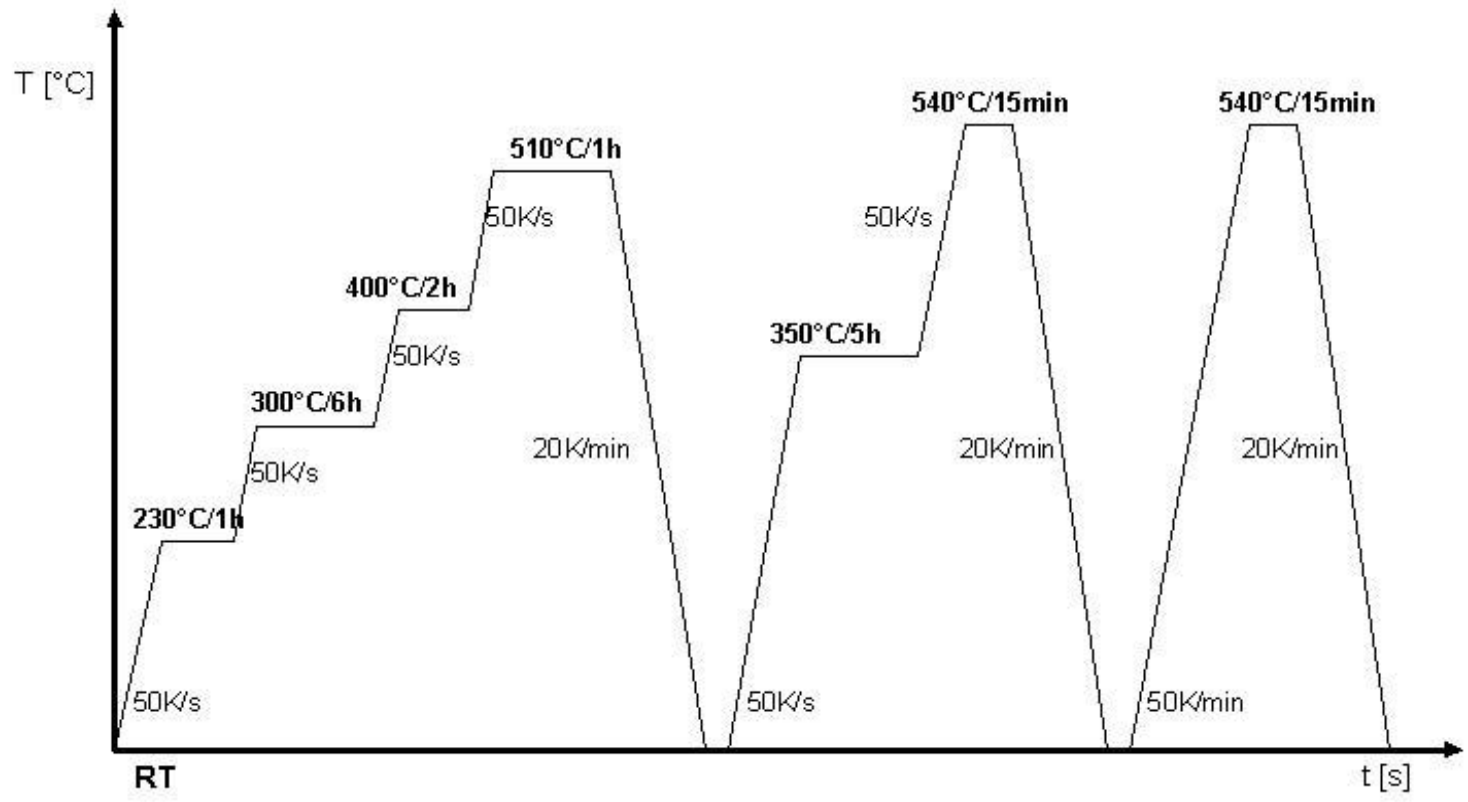

Figure 3.36 Test 3 - Measurements of as cast AISi7Mg0.3 


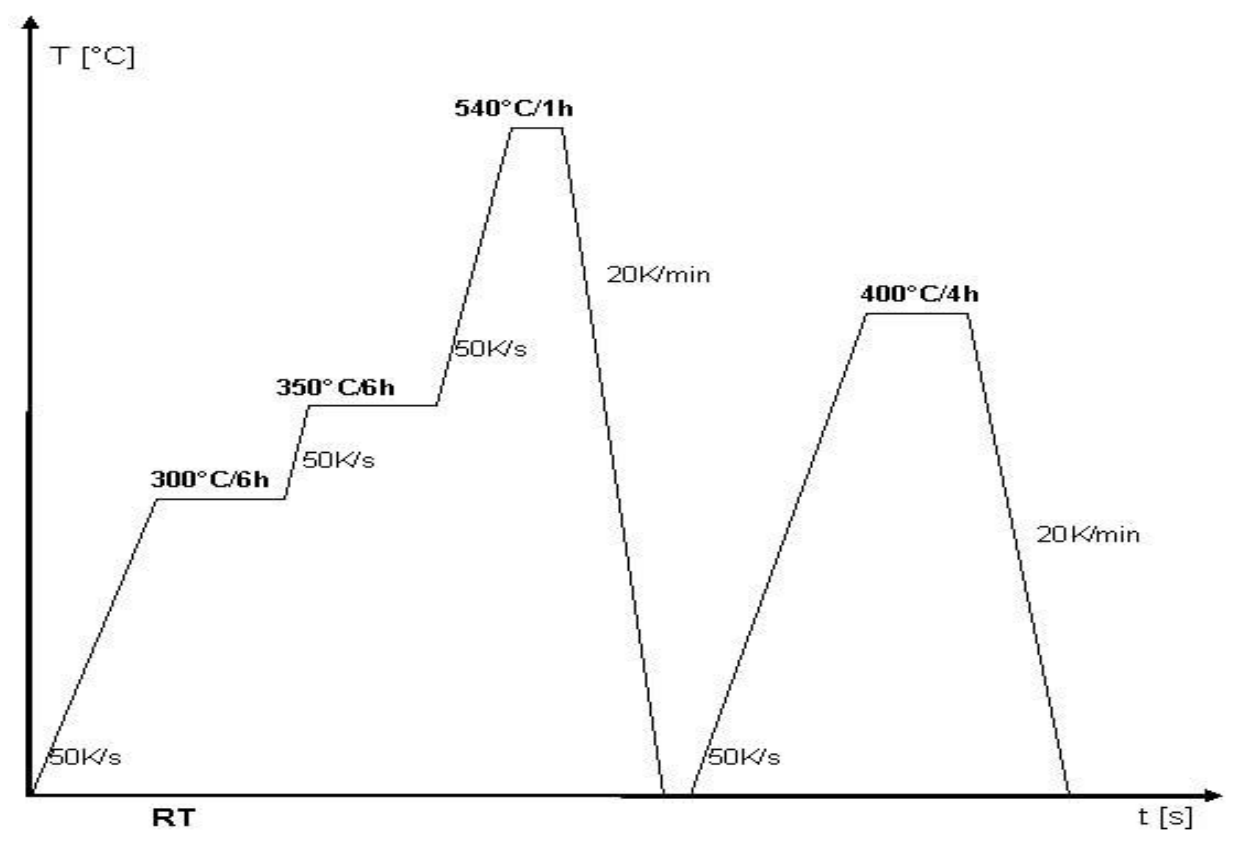

Figure 3.37 Test 4 - Measurements of as cast AlSi7Mg0.3

\subsubsection{Differential Scanning Calorimetry (DSC)}

Differential Scanning Calorimetry (DSC) is a thermal analysis method that measures the heat evolution from a sample under a controlled temperature scan and is under continuous development [63].

DSC monitors heat effects associated with phase transitions and chemical reactions as a function of temperature. DSC is used to determine a wide range of thermophysical properties of materials, including the glass-transition temperature $\mathrm{Tg}$, the melting temperature $\mathrm{Tm}$, and solid-solid transitions.

The DSC system used consists of the electronic system (Figure 3.38 a) and the cell, which contains its own thermocouples (temperature sensor) for monitoring differential heat flow and temperature (b). The DSC cells use a constantan disc as a primary heat-transfer element. A silver heating block, capped with a vented silver lid, encloses the constant disc.

The selected sample and reference sample are placed in pans that sit on raised portions of the disc. Heat is transferred through the constantan disc to both the samples and reference pans. Differential heat flow to the sample and reference are monitored by the chromel constantan thermocouples. The thermocouples are fixed at the junctions of the constantan disc and the chromel wafers welded to the underside of the two raised portions of the disc. Chromel and alumel wires are connected to the chromel wafers at the thermocouple junctions to measure the samples temperature. The alumel wire is for thermal balance. Purge gas, entering the heating block through an inlet the DSC cells base plate, is preheated to block temperature by circulation before entering the sample chamber through the purge gas inlet. Gas exits through the vent hole in the silver lid. Vacuum and air cooling ports in the DSC lead to openings in the cell but not directly to the sample chamber. 
A bell jar, placed over the cell and sealed with an O-ring, protects the operator from evolved gases and permits cell evacuation [20].
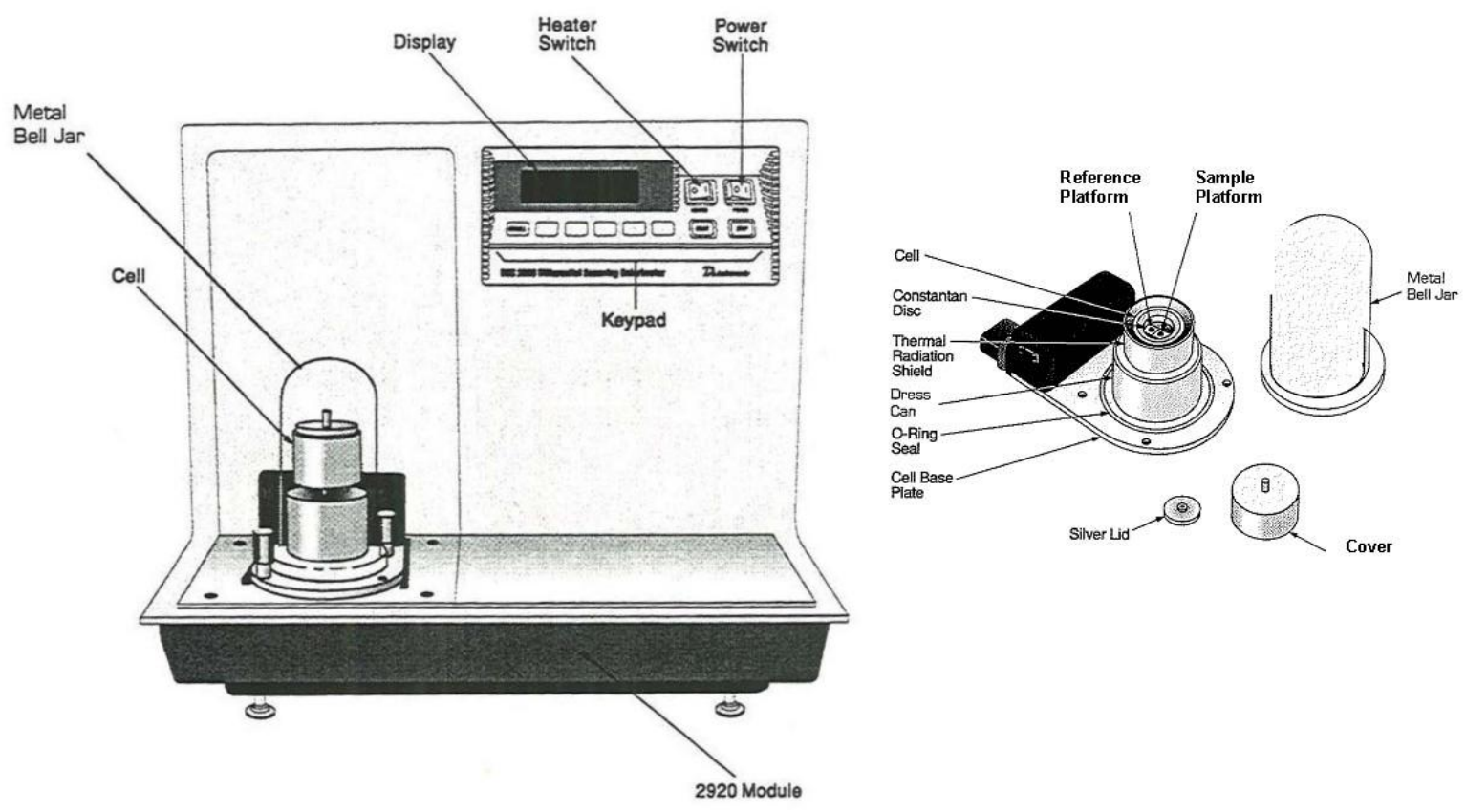

a)

b)

Figure 3.38 View of the instrument DSC 2920 (from TI instruction)

DSC (Differential Scanning Calorimetry) was carried out with AlSi7Mg0.3 alloys. Two different samples were tested from the step cast sample and from the demo-axial sample in a cast condition, heated to $165^{\circ} \mathrm{C}$ for 10 hours and heated to $250^{\circ} \mathrm{C}$ for 5 hours. During measurements of the heat treated samples, a heating rate of $10 \mathrm{~K} / \mathrm{min}$ was used in nitrogen atmosphere. The tests in the DSC were carried out in a temperature interval between $30^{\circ} \mathrm{C}(\mathrm{RT})$ and $540^{\circ} \mathrm{C}$ (Figure 3.39).

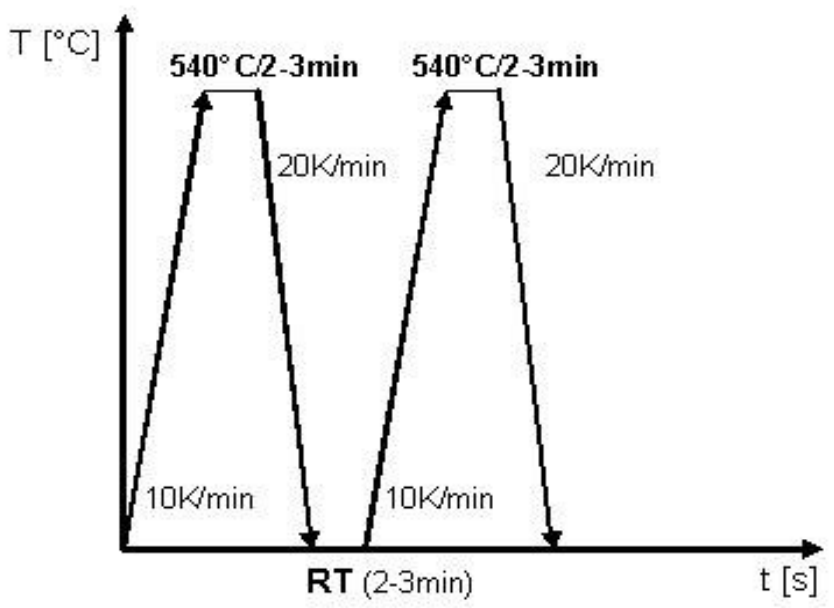

Figure 3.39 Temperature-Time curves of DSC measurements of AISi7Mg from the step cast sample 


\subsubsection{Compression test}

Compression tests of the sample were carried out using a Gleeble Machine 1500. The temperature was controlled by a K-type thermocouple fixed in the middle of the sample (see Figure 3.40). The size of the samples used for the compression test was of $ø 10 \times 15 \mathrm{~mm}$.

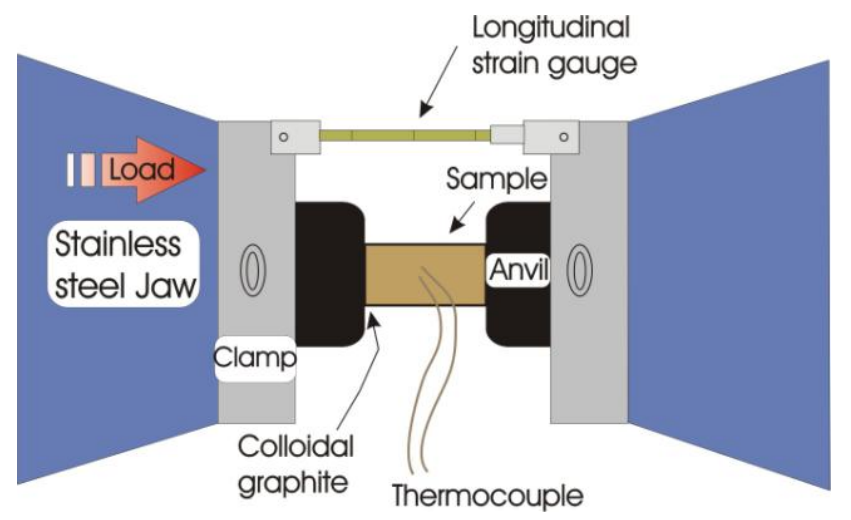

Figure 3.40 View of the equipment for the compression test (Gleeble Machine 1500)

Specimens from the insert free cast sample (see Figure 3.6) have been used for this part of the experiments. Two different tests had to be done for the compression test in the laboratory at the TU Wien. The tests were performed after an annealing treatment at $350^{\circ} \mathrm{C}$ to eliminate precipitation hardening of the AlSi7Mg0.3 alloy by over aging.

In the first test, the samples were heated till $350^{\circ} \mathrm{C}$ for $3 \mathrm{~min}$, then were cooled down to the temperature of deformation (Figure $3.41 \mathrm{a}$ ), where it was held for $30 \mathrm{sec}$ before compression.

For the second test series we heated the samples till deformation temperature above the annealing temperature, held it 30sec before deformation (Figure $3.41 \mathrm{~b}$ ).

The stress strain curve was evaluated to yield the flow stress at the true strain: $\varepsilon=0.02$
a)
$\mathrm{Td}=$ temp. deformation
$140,170,200,220,250,300^{\circ} \mathrm{C}$
Heating rate: $10 \mathrm{~K} / \mathrm{s}$
Strain rate: $0.1 / \mathrm{s}$

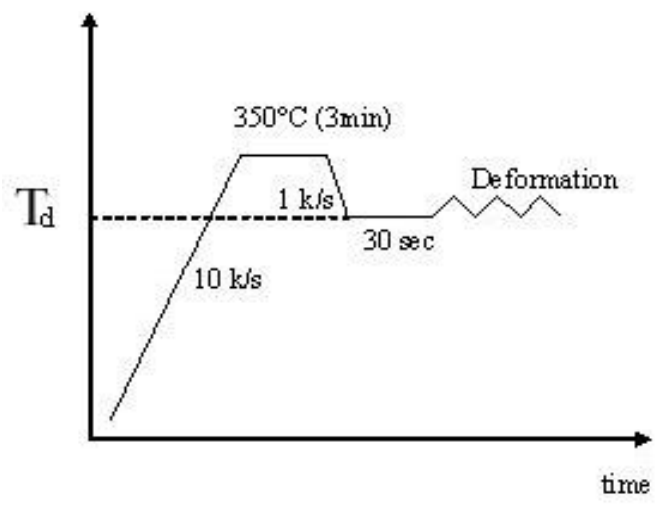


b)

$\mathrm{Td}=$ temp. deformation $400,450,500,530^{\circ} \mathrm{C}$

Heating rate: $10 \mathrm{~K} / \mathrm{s}$

Strain rate: $0.1 / \mathrm{s}$

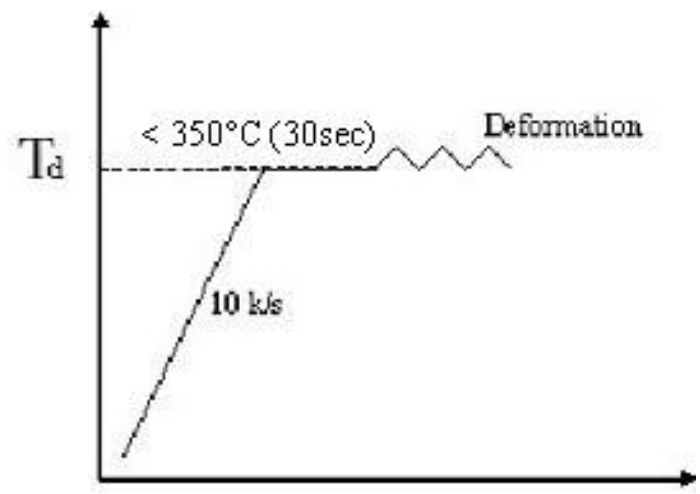

Figure 3.41 Sketch of the temperature exposure for the two compression test series

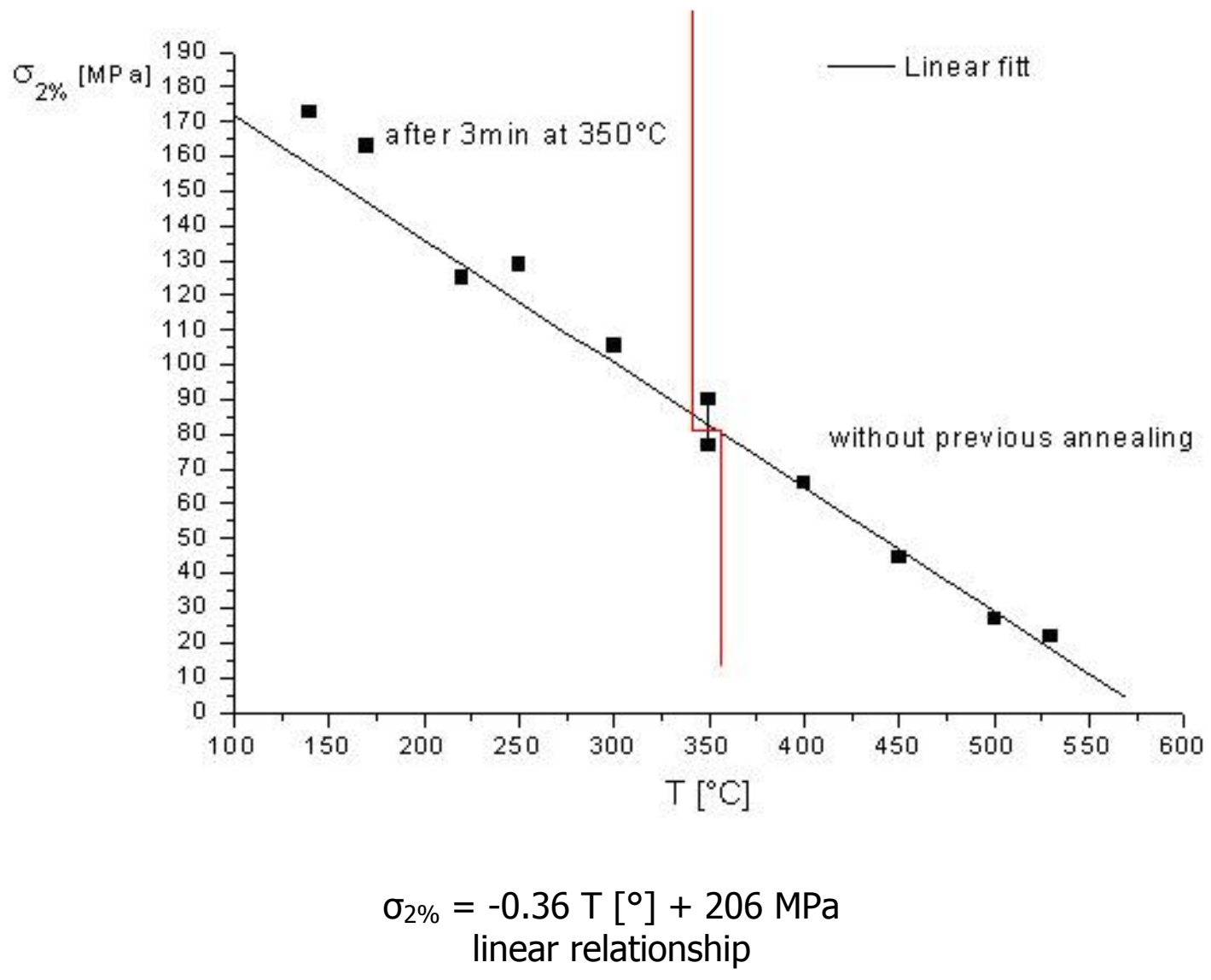

Figure 3.42 Graph showing the stress at 0.02 of the true strain with the temperature 


\subsubsection{X-ray diffraction analysis}

The internal stresses of the aluminium around the steel insert were measured by $\mathrm{X}$ ray diffraction at TU-Wien, where the $\sin ^{2} \Psi$ method was used. The sample was cut perpendicular to the insert axis, in the middle of the thickness into two equivalent halves. The surface of the sample was polished. The lower part of the samples was used for the measurements (Figure 3.43). The stress analysis of that sample is shown in Figure 4.63.

- Aluminium

- Peak (311) $94.2^{\circ}$

- Elastic modulus $6910^{3}$ [MPa]

- Poisson's ratio 0.35

- Co Cathode Ka1 $1.78897 \AA$

- $\sin ^{2} \Psi$ method:

$$
\begin{aligned}
& -\mathrm{s}_{1}=5.1110^{-6}\left[\mathrm{MPa}^{-1}\right] \\
& 1 / 2 \mathrm{~s}_{2}=19.5410^{-6}\left[\mathrm{MPa}^{-1}\right]
\end{aligned}
$$

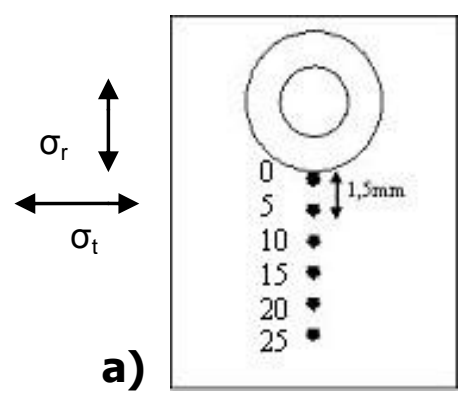

b)

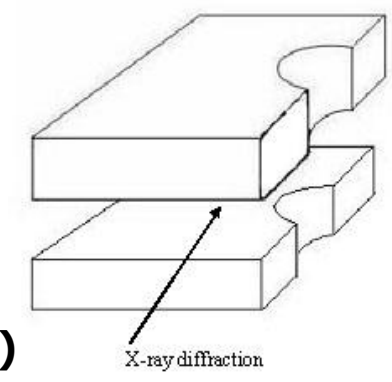

Figure 3.43 View of the central plane of the sample used for X-ray diffraction analysis with the positions of measurements

For another measurement were used the same halves of sample 10 (Figure 3.44). Two points in aluminium and in steel were measured on each side of the sample (see Figure 3.44 a). For all calculations the same parameters were used as for measurements described before.

- Aluminium

\section{Results:}

\begin{tabular}{|c|c|c|}
\hline & $\boldsymbol{\sigma}_{\mathbf{r}}[\mathrm{MPa}]$ & $\boldsymbol{\sigma}_{\mathbf{t}}[\mathrm{MPa}]$ \\
\hline Middle plane (a) & -33 & -90 \\
\hline Surface flat (b) & -31 & -78 \\
\hline
\end{tabular}


- Steel

- Peak (211) $99.7^{\circ}$

- Elastic modulus $22010^{3}$ [MPa]

- Poisson's ratio 0.28

- Co Cathode Ka1 $1.78897 \AA$

- $\sin ^{2} \Psi$ method:

$$
\begin{aligned}
& -\mathrm{s}_{1}=1.2710^{-6}\left[\mathrm{MPa}^{-1}\right] \\
& 1 / 2 \mathrm{~S}_{2}=5.8110^{-6}\left[\mathrm{MPa}^{-1}\right]
\end{aligned}
$$

\section{Results: after quenching from $350^{\circ} \mathrm{C}$}

\begin{tabular}{|c|c|c|}
\hline & $\boldsymbol{\sigma}_{\mathbf{r}}[\mathrm{MPa}]$ & $\boldsymbol{\sigma}_{\mathbf{t}}[\mathrm{MPa}]$ \\
\hline Middle plane (c) & -324 & -368 \\
\hline Surface flat (d) & -318 & -366 \\
\hline
\end{tabular}

Middle plane

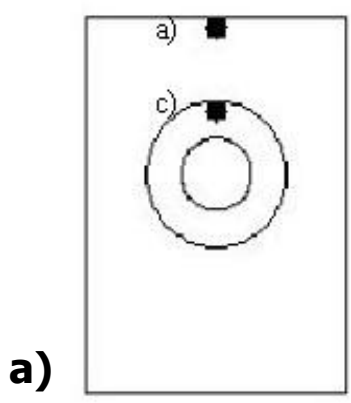

Surface flat

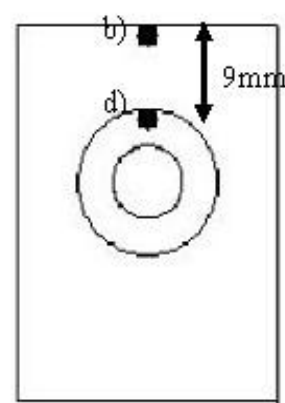

Medre pare

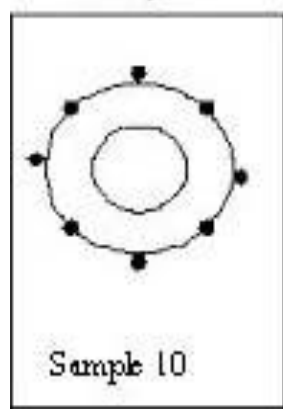

Figure 3.44 Sketch of the sample 10 used for X-ray diffraction according to positions of measurements

Sample 10 was used in order to measure the radial stresses on the Al-steel interface, where the sample was turned in $45^{\circ}$ steps during the measurements (Figure $3.44 \mathrm{~b}$ ). Results from the measurement are shown in Figure 4.66.

For the Neutron Diffraction measurements we used AlSi7 alloy. The measurements were performed at Helmholtz Zentrum Berlin [64]. Results are shown in Figure 4.64.

\subsubsection{Pull out test}

Pull out tests were performed with as cast and heat treated demo-prototype samples. The force of the bonding between steel and Al was measured by a Zwick Z050 testing machine (Figure 3.45).

The results of the pull out tests are shown in Figure 4.67. 

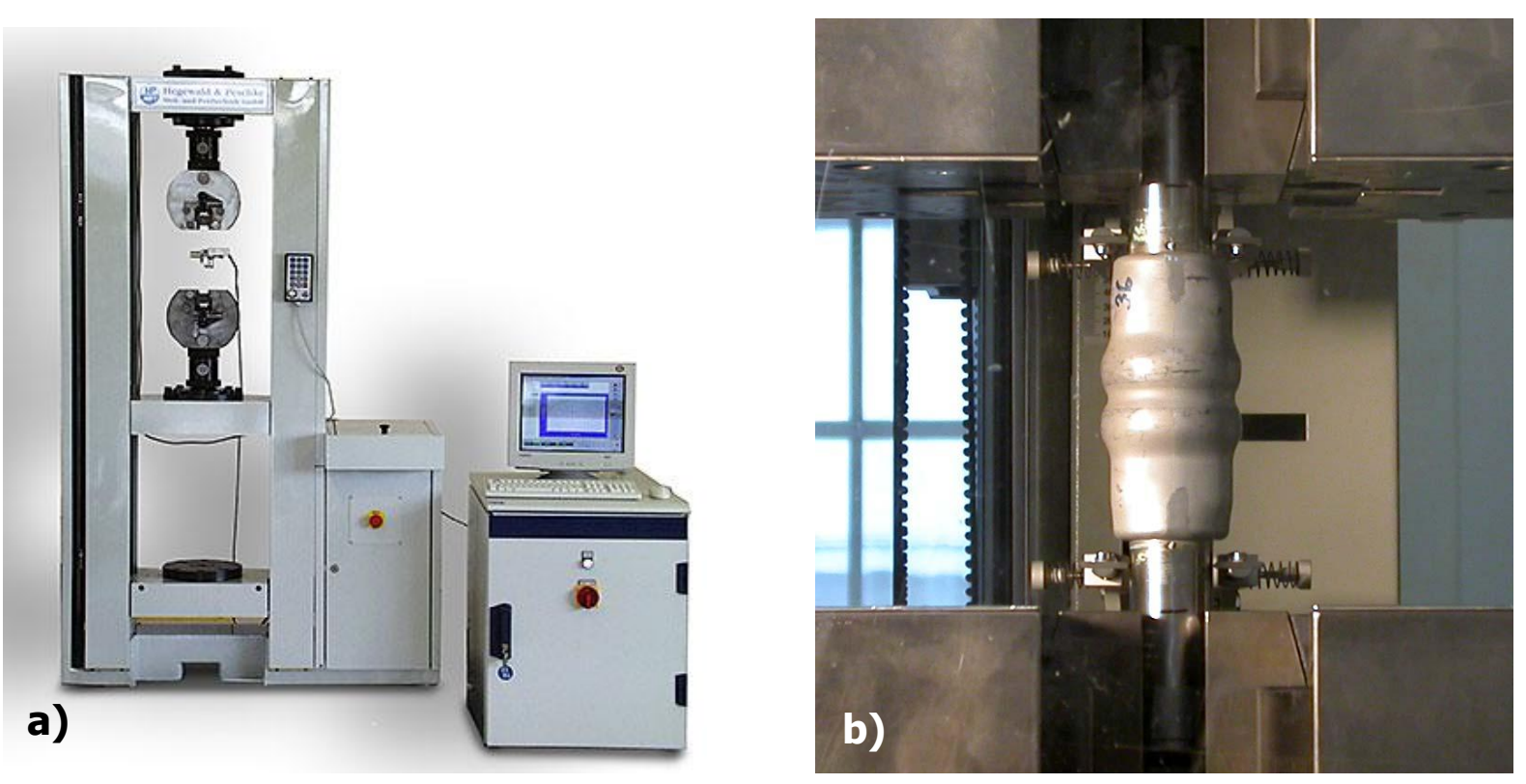

Figure 3.45 a) Zwick Z050 testing machine, b) tensile test

\subsubsection{Laser Ultrasound}

LUS is a contactless, non-destructive measurement method $[65,66]$, which in addition has the ability to generate and detect very high frequency ultrasound waves. It consists of a generation and a detection unit.

The generation is performed by focusing a pulsed high energy laser with pulse times in the region of picoseconds to nanoseconds on the surface of a sample [67]. These pulses, which can be mathematically approximated as Dirac pulses, lead to very high frequency and broadband ultrasound waves (from $\mathrm{kHz}$ to $\mathrm{GHz}$ ).

The contactless detection can be done by different setups and geometries like standard interferometric setups (Michelson interferometer and Fabry Perot interferometer) or more sophisticated setups (e.g. photorefractive interferometers). A state of the art photorefractive interferometer with a very broad band signal response $(100 \mathrm{kHz}$ to $1.2 \mathrm{GHz})$ is used.

Bulk waves were generated by focussing picoseconds laser pulses with energies of $5 \mathrm{~mJ}$ to a small spot on the inner side of the steel tube. On the opposite side (on the aluminium surface) the arriving bulk waves are detected by the photorefractive detector. The interface of the sample is scanned by revolution of the sample and subsequently stepping along the $X$-axis up to 22 steps $1 \mathrm{~mm}$ each.

Laser Ultrasound measurement was performed on the demo-axial samples in a cast condition and after aging at $165^{\circ} \mathrm{C}$ for 2.5 hours. 


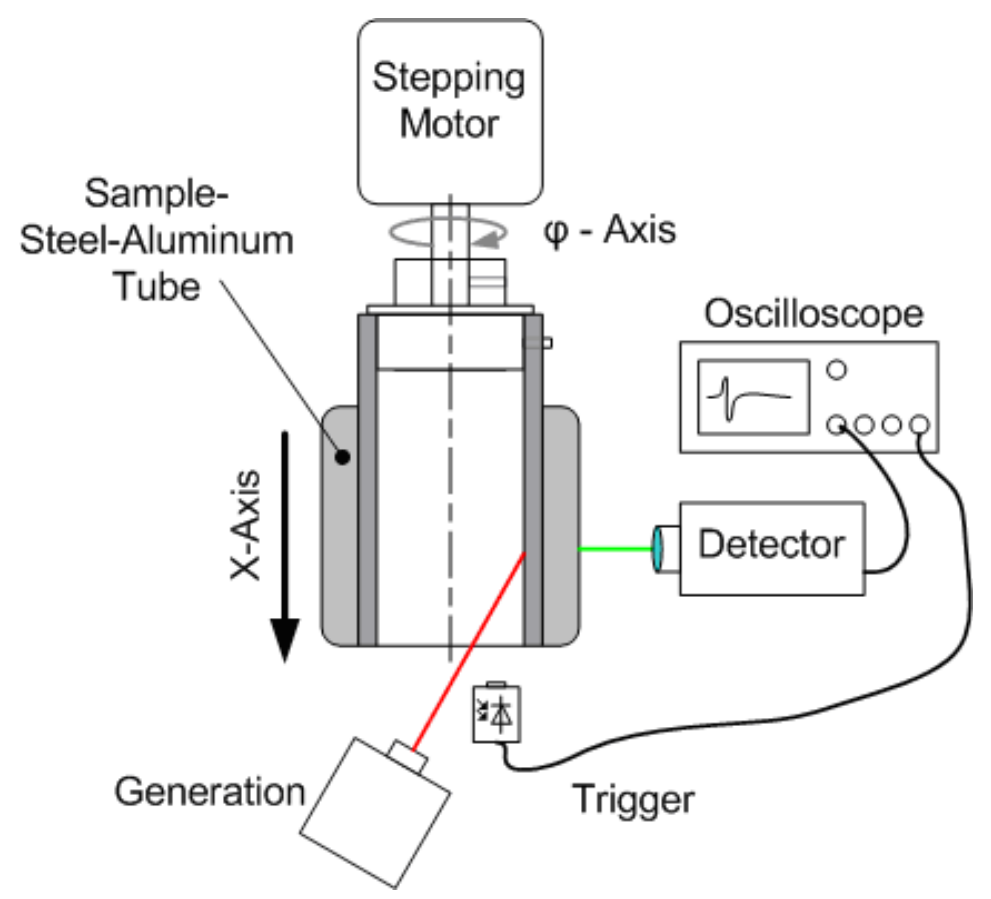

Figure 3.46 Measurement setup for non destructive Laser generated ultra sound wave detection; Laser beam scanned the inner cylinder whereas the detectors canned the outside

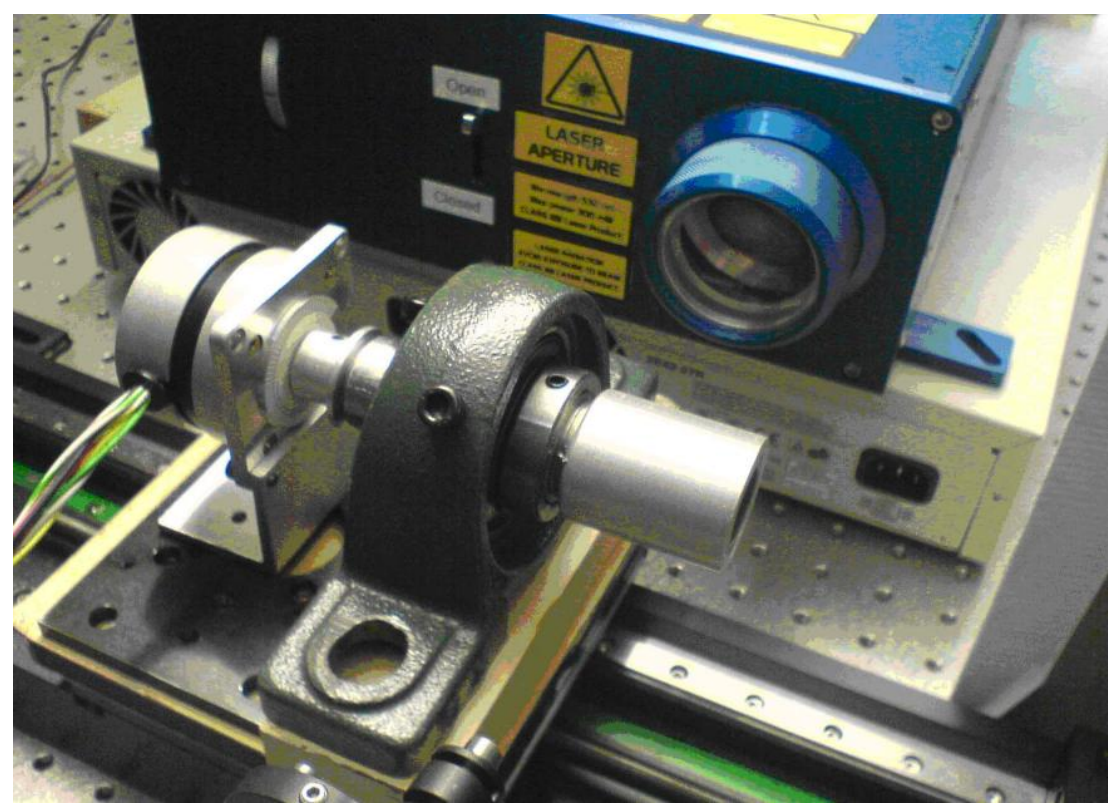

Figure 3.47 The demo-axial sample mounted on the step motor for LUS 



Figure 3.48 Cutting of the demo-axial sample to obtain left and right tube section

\section{Calculation of the running time:}

- Longitudinal - Transversal

$$
\begin{aligned}
& v_{\text {long }} \approx 6000 \mathrm{~m} / \mathrm{s} \\
& v_{\text {troms }} \approx 3100 \mathrm{~m} / \mathrm{s} \\
& s=\sqrt{(5+5)^{2}+3^{2}}=10.44 \mathrm{~mm} \\
& t_{\text {lomg }}=\frac{s}{v_{\text {long }}}=1.7 \mu \mathrm{s} \\
& t_{\text {trons }}=\frac{s}{v_{\text {trons }}}=3.4 \mu \mathrm{s}
\end{aligned}
$$

- Mode converted wave

$$
\begin{aligned}
& S_{\text {mod }} \approx \sqrt{(5+5)^{2}+3^{2}}=10.44 \mathrm{~mm} \\
& v_{\bmod } \approx \frac{3000+6000}{2}=4500 \mathrm{~m} / \mathrm{s} \\
& t_{\text {mod- }} \frac{s_{\bmod }}{v_{\bmod }}=2.3 \mu \mathrm{s}
\end{aligned}
$$


- Die Rayleigh Waves runs as SAW (Surface Acoustic Wave) around the surface

$$
\begin{aligned}
& s_{\text {raleigh }}=3+10=13 \mathrm{~mm} \\
& v_{\text {rquleigh }} \approx 3000 \mathrm{~m} / \mathrm{s} \\
& t_{\text {rayleigh }} \frac{s_{\text {rquleigh }}}{v_{\text {rquleigh }}}=4.3 \mu \mathrm{s}
\end{aligned}
$$




\section{Chapter 4}

\section{Results}

\subsection{Temperature measurements on step sample}

To measure the cooling rate we used the whole step sample $4 \mathrm{~g}$. The sample was heated till $510-530^{\circ} \mathrm{C}$ for $15 \mathrm{~min}$ and water quenched within a few seconds. The casting was immersed into the water with the flat bottom parallel to the water surface.

To measure the cooling rate we used special equipment with 10 thermocouples fixed on the surface and inside the sample (2mm deep), (Figure 3.26). Two thermocouples were fixed on the surface and the rest inside the sample. The sample regions $\mathrm{Nr} 1$, $3,7,8$ and sample 9 had been investigated by metallography.

The cooling rates are evaluated from $530^{\circ} \mathrm{C}$ to $120^{\circ} \mathrm{C}$ (Figure 4.1). In the sector of the casting thickets $(25 \mathrm{~mm})$ the cooling is the slowest $(40-60 \mathrm{~K} / \mathrm{s})$. The outer positions of Al cooled down by $150 \mathrm{~K} / \mathrm{s}$. The thin section $(10 \mathrm{~mm})$ reaches cooling rates between $40-160 \mathrm{~K} / \mathrm{s}$. The slowest cooling we can observe in the thick section $(25 \mathrm{~mm})$ in the steel and at the interface, where the cooling rates range between 40 $70 \mathrm{~K} / \mathrm{s}$.

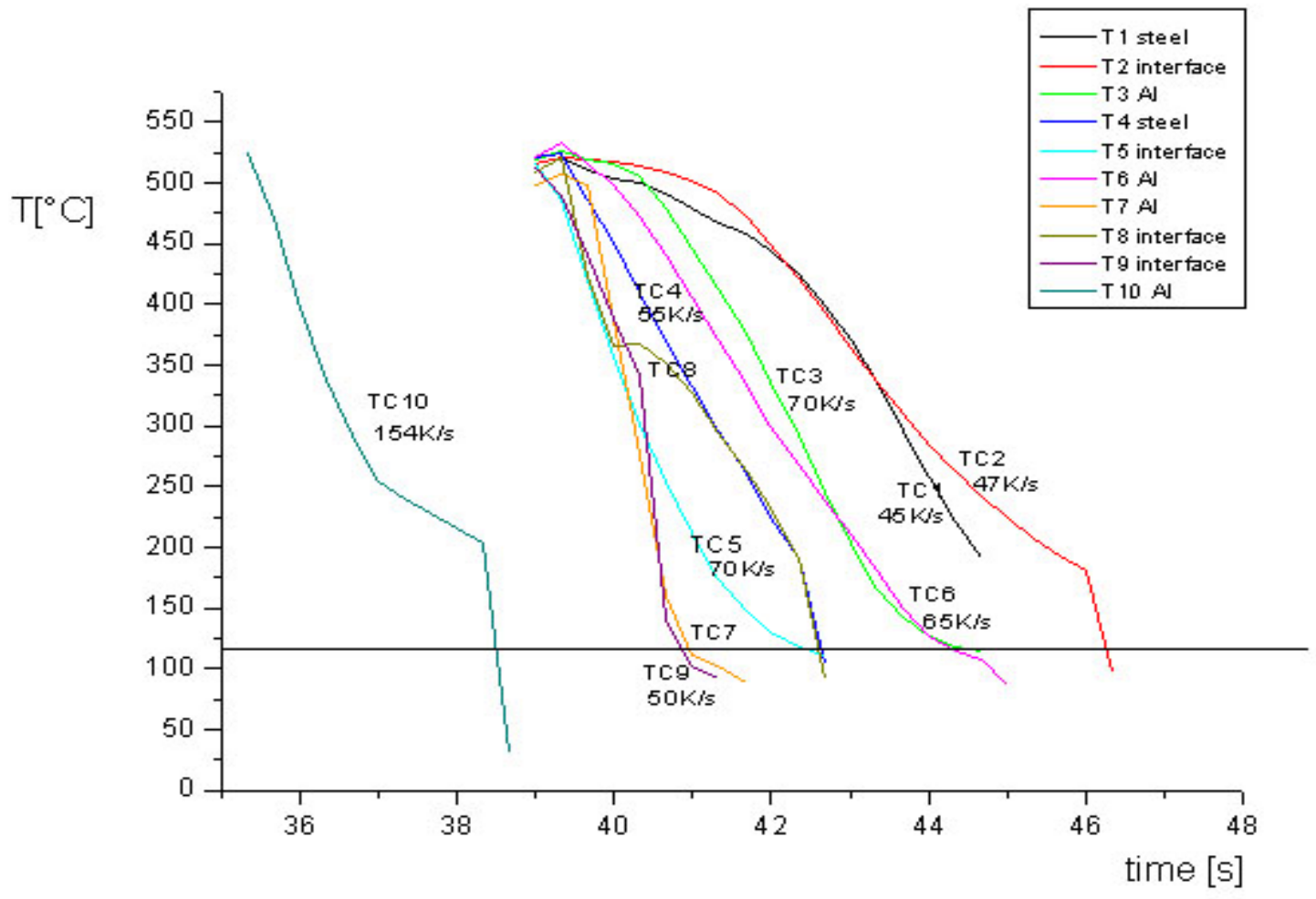

Figure 4.1 Graph of the cooling rates from 530 to $150^{\circ} \mathrm{C}$ at different positions in the step sample 


\subsection{Metallography}

\subsubsection{Gravity die casting}

- Rods sample
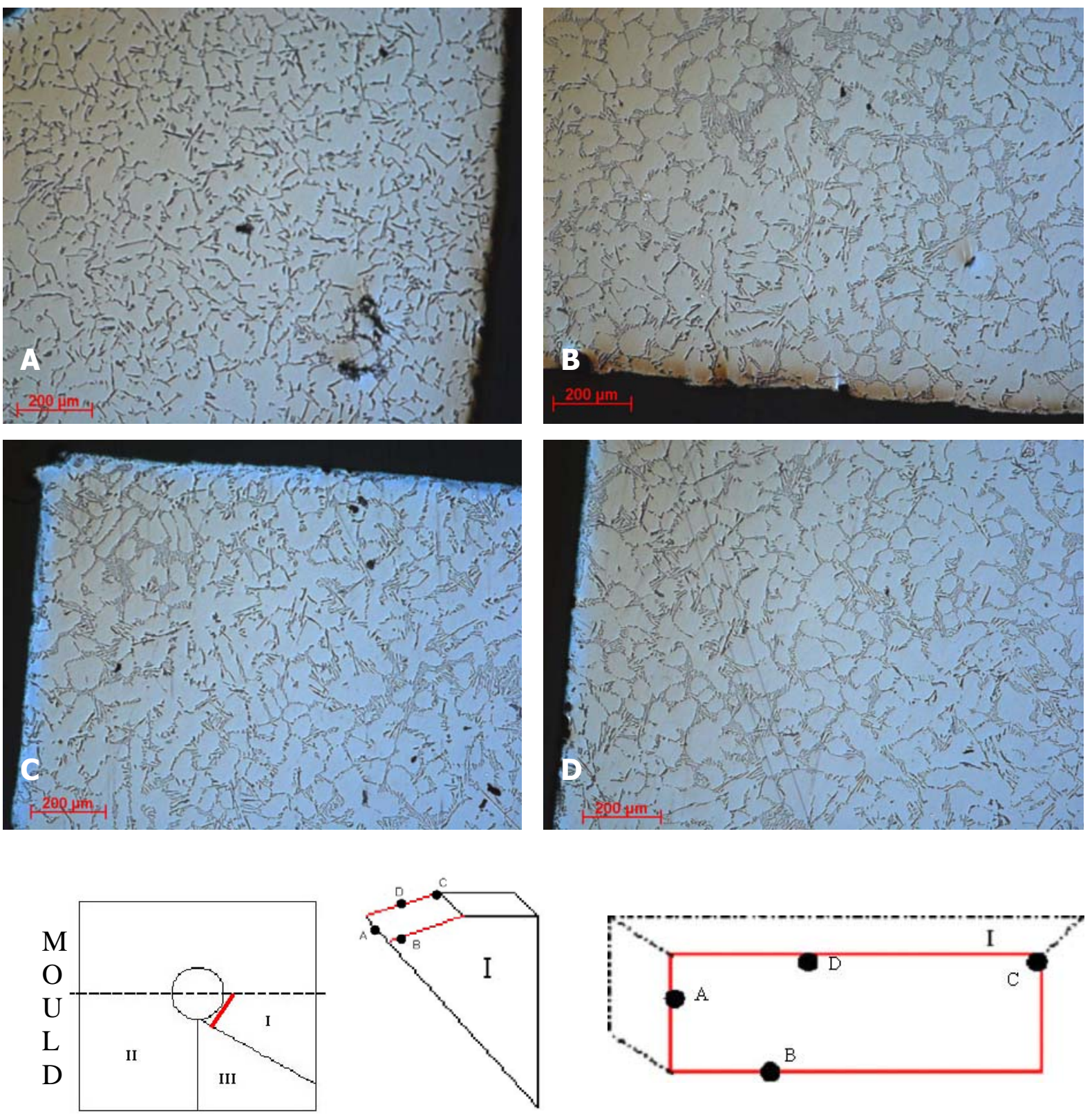

E) Sketch of the sample 2 (I) used for LOM with indicated positions of the micrographs

Figure 4.2 Light Optical Microscopy of the rod sample 2 according to positions of the micrographs indicated in Figure $4.2 \mathrm{E}$ 
Sample 2 (oxide) was used to characterize the micro-structure of the sample and the interface between aluminium and steel. Photomicrographs of the sample 2 close to the interface at small magnification are shown in Figure 4.2. We can observe quite normal structure, where the dendrite cell size measures from about $40 \mu \mathrm{m}$ in Figure $4.2 \mathrm{~B}$ to about $60 \mu \mathrm{m}$ in Figure $4.2 \mathrm{~A}$. The amount of interdendritic eutectic seems to increase towards the bonders of the casting.

Figure 4.3 and Figure 4.5 show the microstructure of the sample 2 and sample 5 at the section II towards the insert. The structure consists mainly of the eutectic Al-Si, with the dendrites between $50-75 \mu \mathrm{m}$. At the position $D$ the dendrites are bigger, growing to about $75 \mu \mathrm{m}$, in Figure 4.6. There dendrites are similar at the interface ( $A$, B) and few $\mathrm{mm}$ away inside the casting.
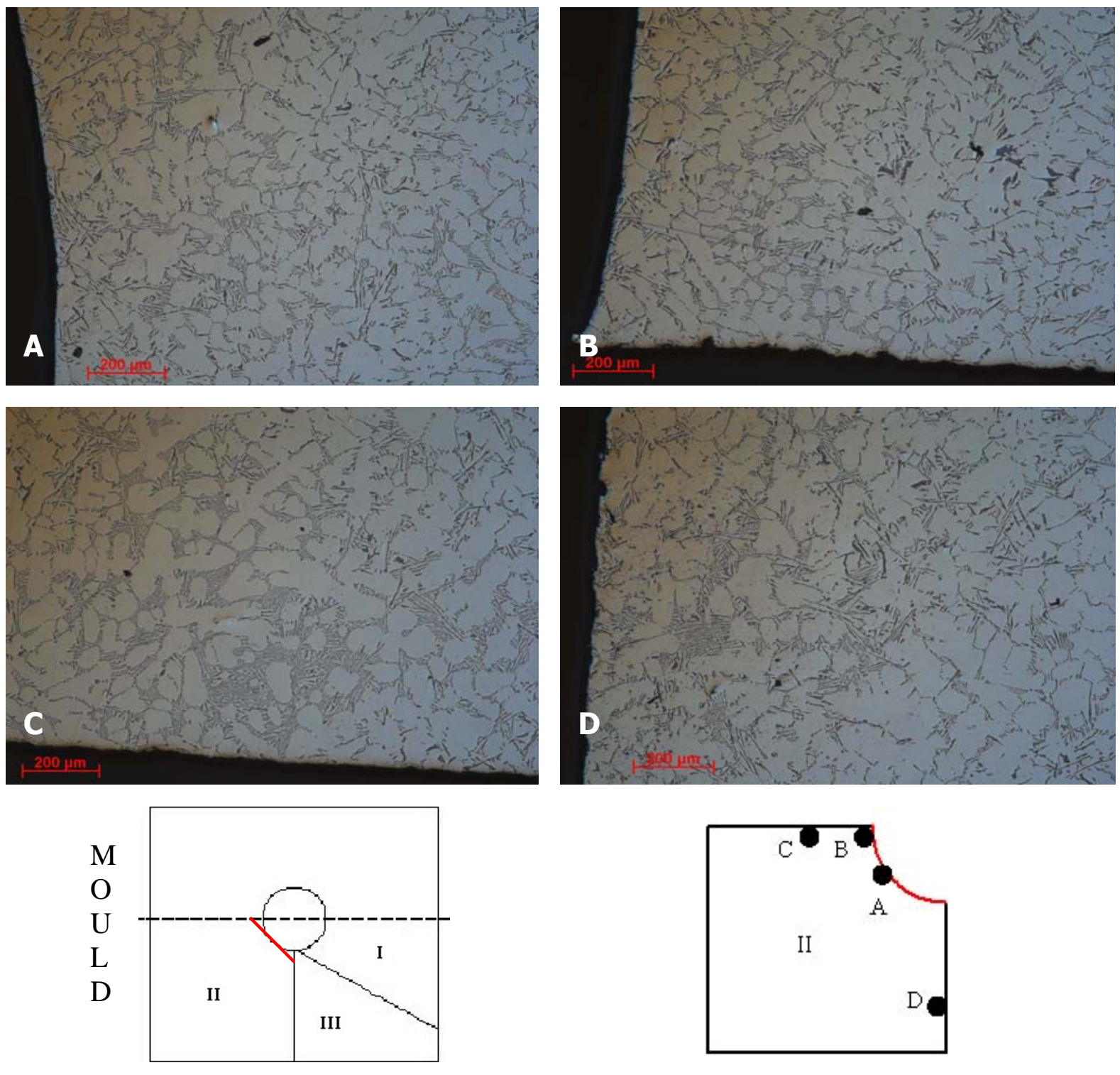

E) Sketch of the sample 2 (II) used for LOM with indicated positions of the micrographs

Figure 4.3 Light Optical Microscopy of the rod sample 2 according to positions of micrographs indicated in Figure $4.3 \mathrm{E}$ 
Figure 4.4 shows the microstructure of the Al-Si casting at the section III, along the interface $(A, B, C)$. The finest structure we can observe at position $D-G$ with the dendrite arms spacing $24 \mu \mathrm{m}$. The SDA increases to about $65 \mu \mathrm{m}$ along the insert, similar to the positions $\mathrm{H}$. Some interdendritic porosity in between is observed.
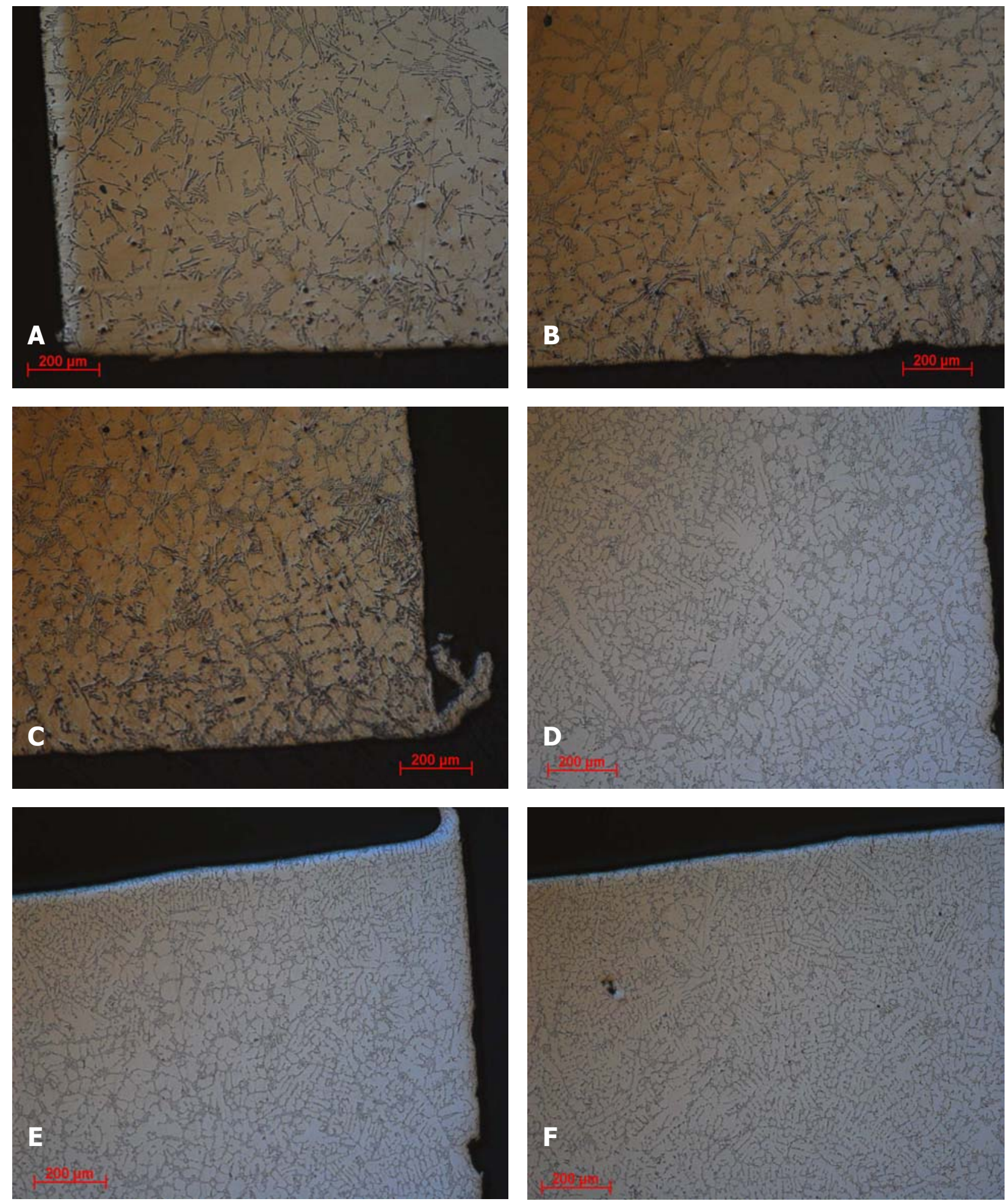

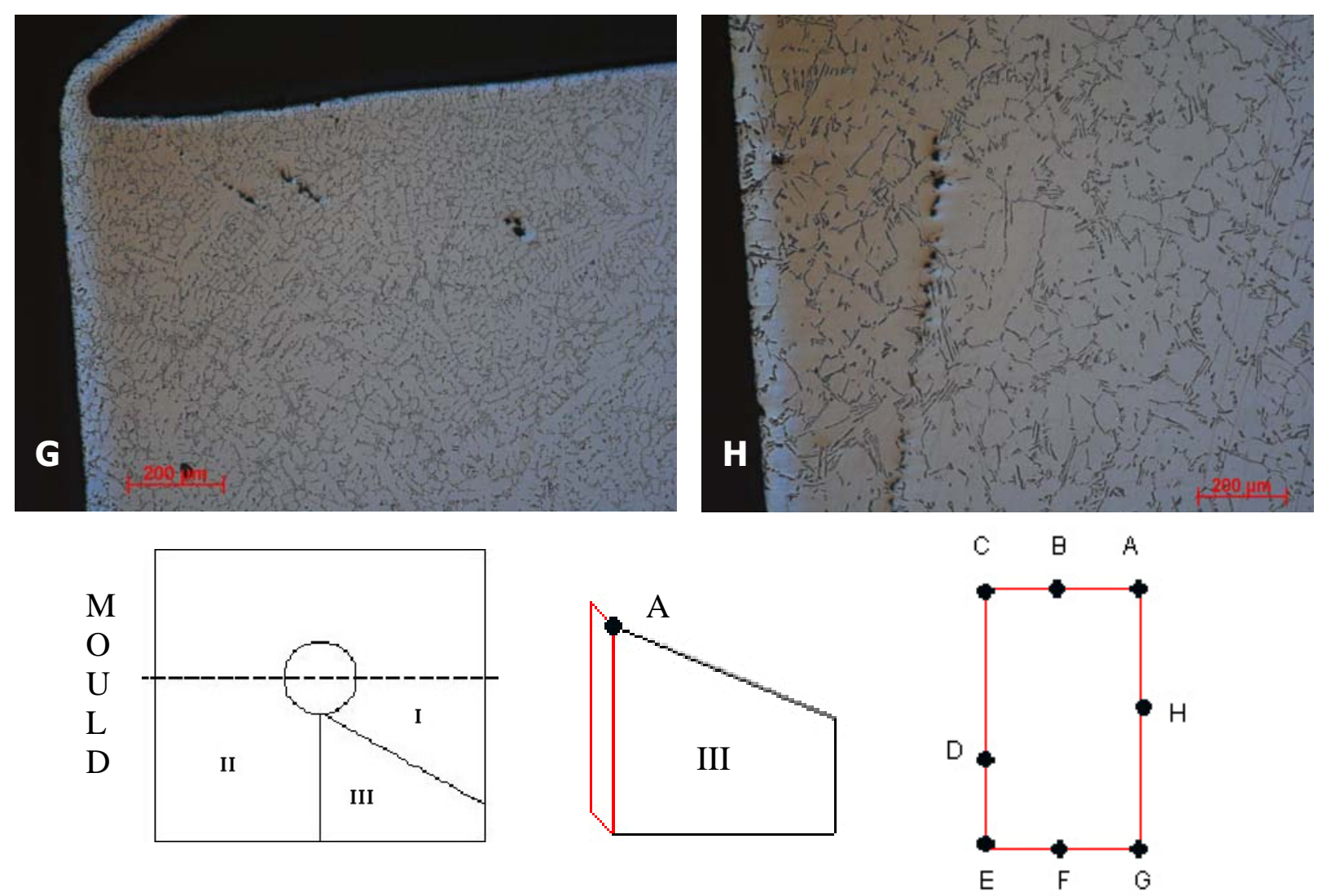

E) Sketch of the surface of the sample (III) used LOM indicating the positions of the micrographs.

Figure 4.4 Light Optical Microscopy of the rod sample 2 according to positions of micrographs indicated in Figure 4.4 E

Figure 4.5 shows the micrographs of the sample 5 in the section I, where the steel stuck to the Al. The dendrite arm spacing changing just a little bit from about $48 \mu \mathrm{m}$ (A) to about $65 \mu \mathrm{m}$ in position $\mathrm{E}$. In the sample 2 we can observe more eutectic than in sample 5.
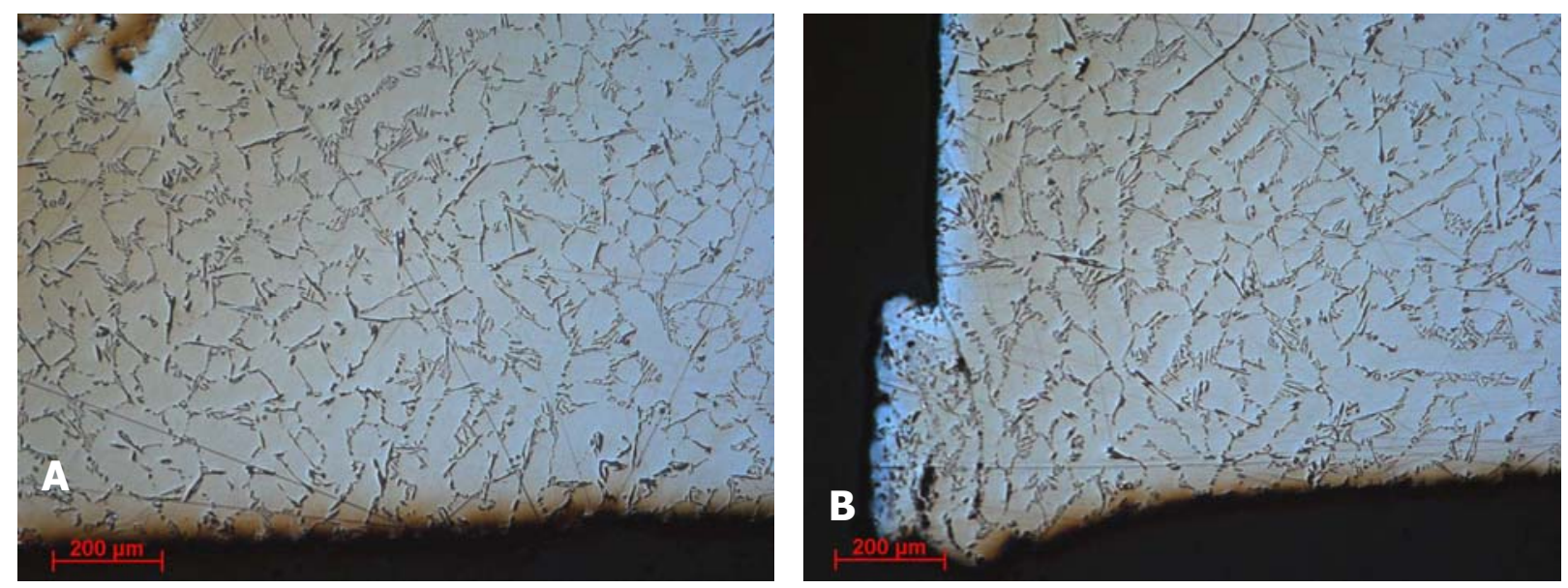

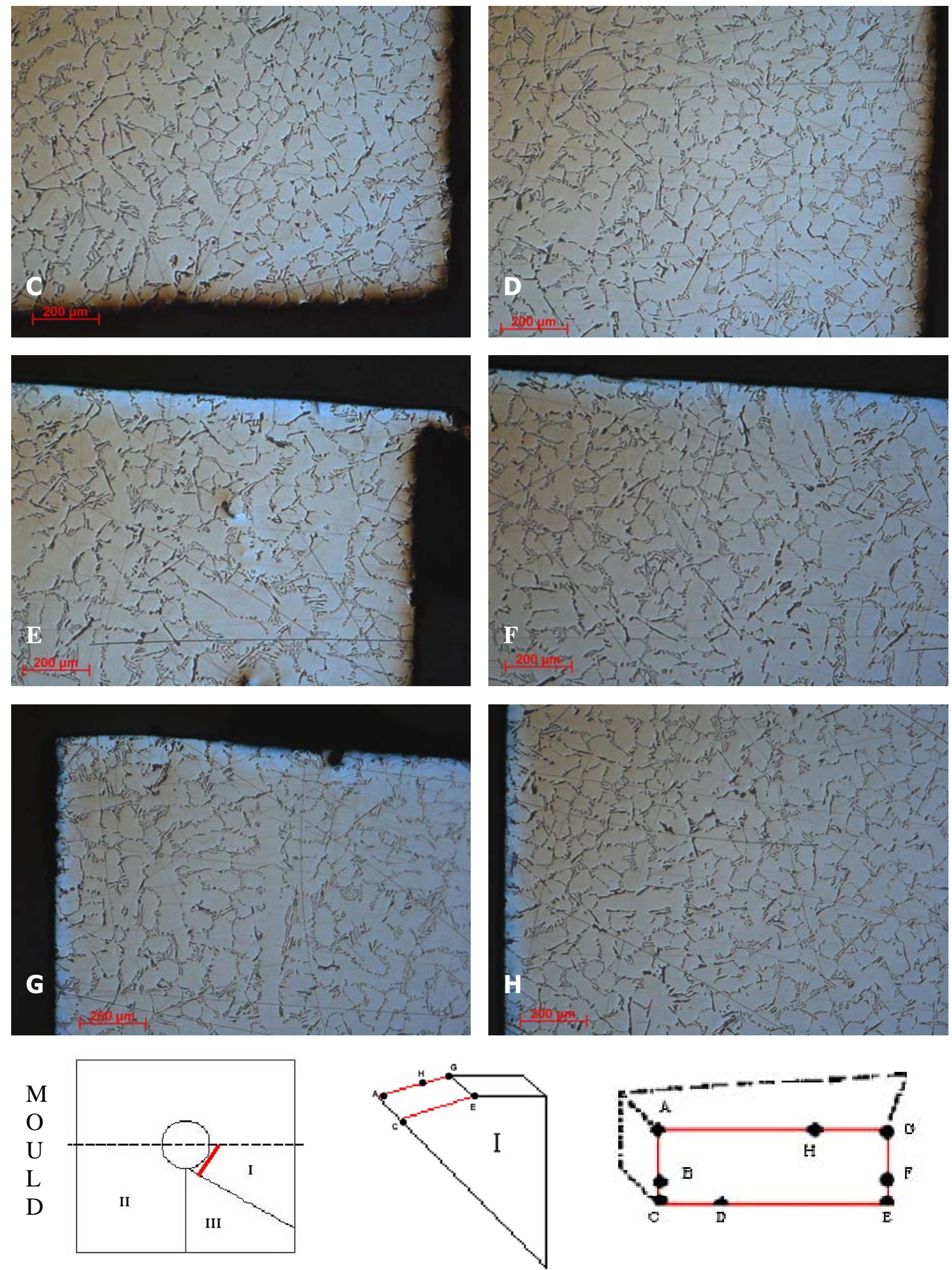

K) Sketch of the surface of the sample 5 (I) used for LOM indicating the positions of the micrographs

Figure 4.5 Light Optical Microscopy of the rod sample 5 according to the positions of micrographs indicated in Figure $4.5 \mathrm{~K}$ 

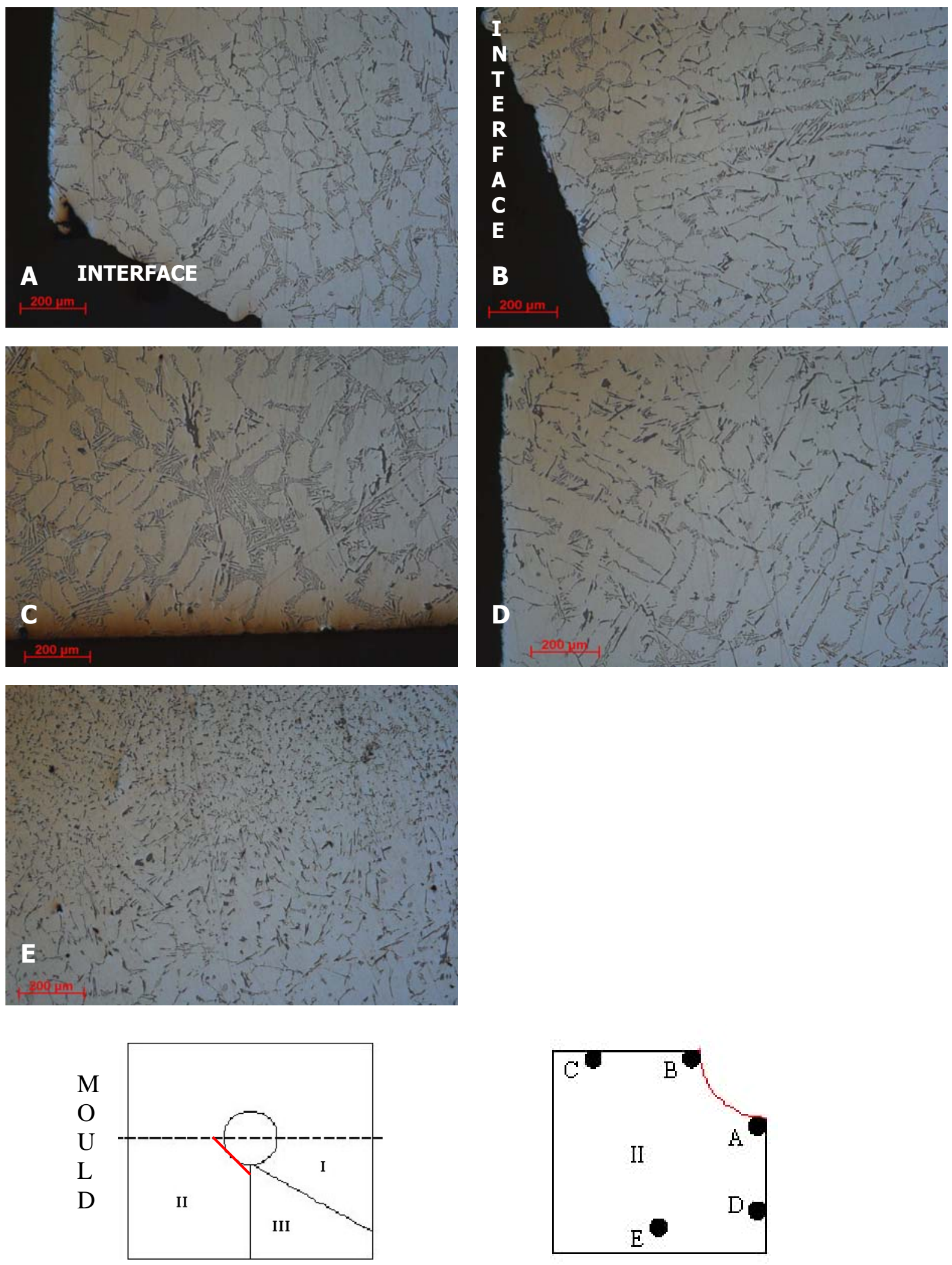

F) Sketch of the surface of the sample 5 (II) used for LOM indicating the positions of the micrographs

Figure 4.6 Light Optical Microscopy of the rod sample 5 according to positions of the micrographs indicated in Figure $4.6 \mathrm{~F}$ 

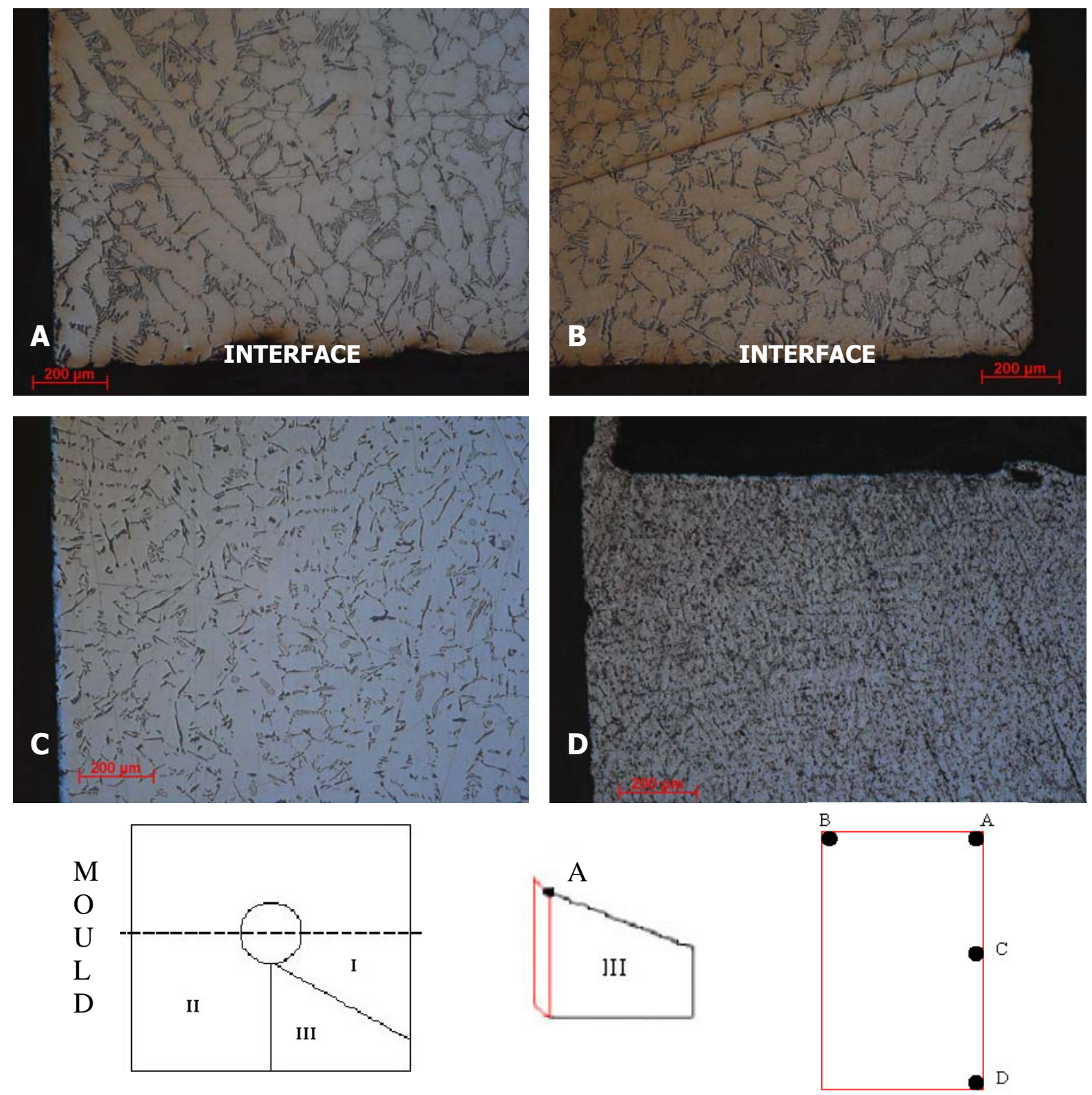

E) Sketch of the surface of the sample 5 (III) used for LOM indicating the positions of the micrographs

Figure 4.7 Light Optical Microscopy of the rod sample 5 according to the positions of the micrographs indicated in Figure $4.7 \mathrm{E}$

In the section II of sample 5 towards the interface we can see in Figure 4.6 that structure consists mainly of the eutectic Al-Si, between the dendrites $50-75 \mu \mathrm{m}$ width. In the positions $B, D$ the dendrite arm spacing measures about $55 \mu \mathrm{m}$, where as in the position $E$ close to the mould the structure is much smaller $(30 \mu \mathrm{m})$.

The section III of the Al-Si casting along the interface we can observe in the Figure 4.7 A, B. The finest structure we can observe in position $D$ with the dendrite arms spacing $5 \mu \mathrm{m}$ in the bulk of aluminium. The SDA increases to about $65 \mu \mathrm{m}$ along the insert, similar to the positions $\mathrm{C}$. 
In Figure 4.8 we can see the different microstructure of the Al-Si casting at the section III as indicated in Figure E. We can observe the changes of the structure, looking at the size of the SDA of about $40 \mu \mathrm{m}$ (at the interface) to about $70 \mu \mathrm{m}$ in a bulk of aluminium. Micrograph $B$ shows increased eutectic zones at the interface section. B contains a significant amount of primary $\mathrm{Si}$. The dendrite cells are considerably bigger $(50-60 \mu \mathrm{m})$ in positions C, D.


E) Sketch of the surface of the sample 3 (III) used for LOM indicating the positions of the micrographs

Figure 4.8 Light Optical Microscopy of the rod sample 3 according to the positions of the micrographs indicated in Figure 4.8 E. 

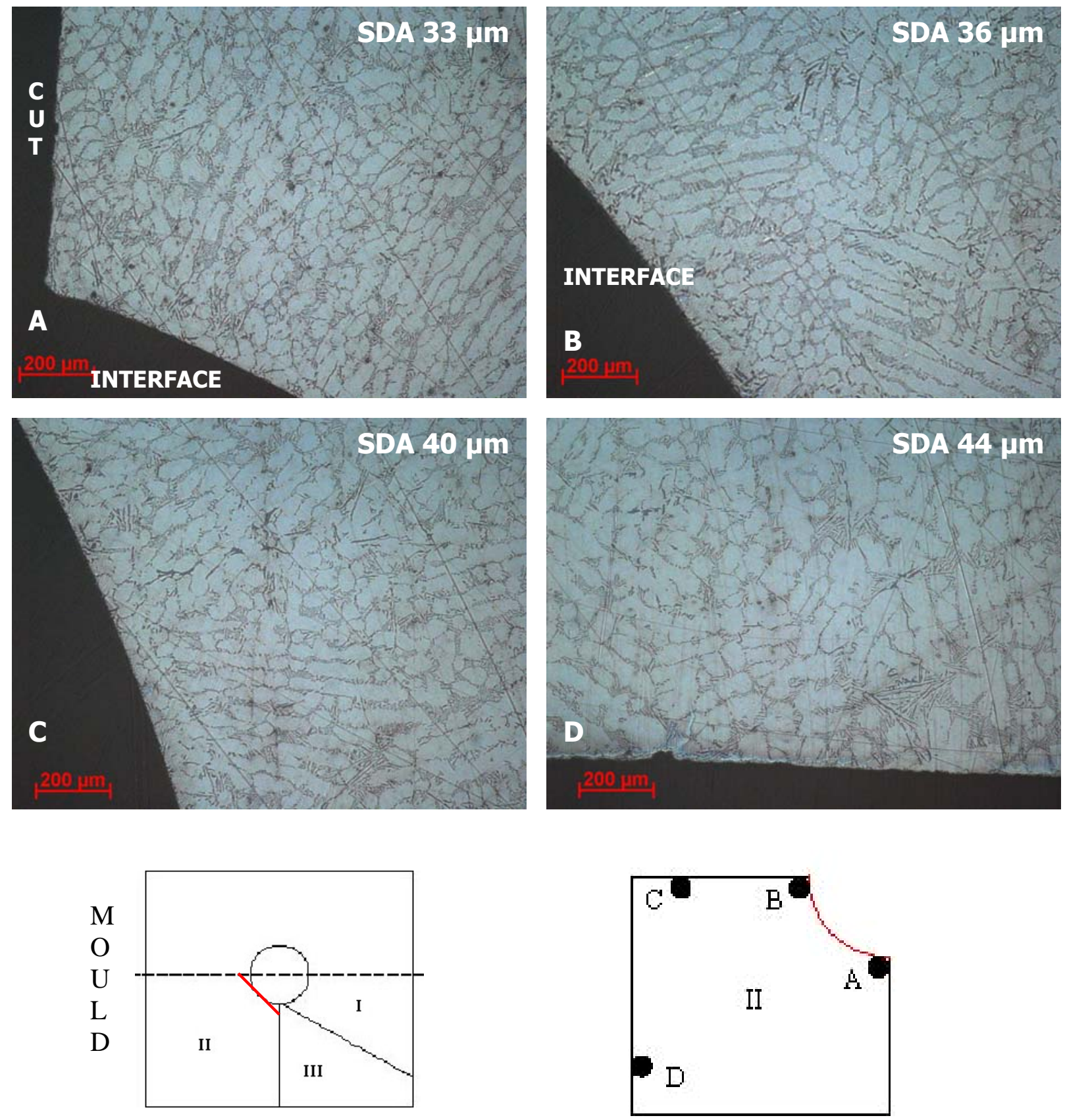

E) Sketch of the surface of the sample 3 (II) used for LOM indicating the positions of the micrographs

Figure 4.9 Light Optical Microscopy of the rod sample 3 according to the positions of the micrographs indicated in Figure $4.9 \mathrm{E}$

In Figure 4.9 photomicrographs at small magnification shown the same microstructure, where the dendrite cell size changes just a little, between $33 \mu \mathrm{m}$ in position A (interface) to about $44 \mu \mathrm{m}$ in position $\mathrm{D}$ close to the mould. The bulk of Al consists mainly of about $25 \%$ of Al-Si eutectic as we can observe. 
The next figure shows the fine microstructure of the sample 7 at the section $\mathrm{I}$, where the steel stuck on the Al (see Figure 4.10 A). The dendrite sells change from about $36 \mu \mathrm{m}$ to about $44 \mu \mathrm{m}$. At the positions C, D we can see that the dendrites grow from the insert. Micrograph at the position $\mathrm{E}$ contains of interdendritic porosity.
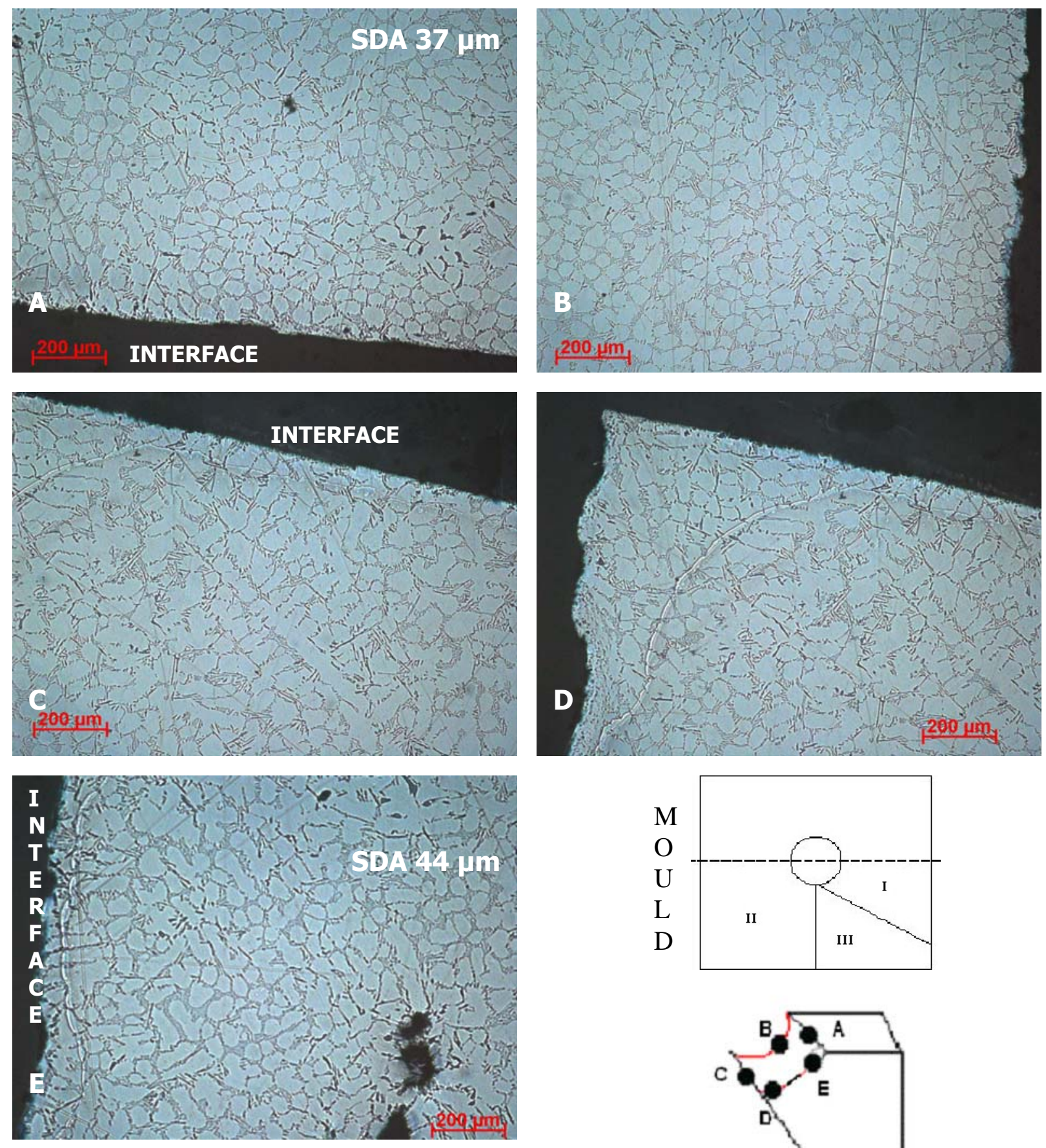

F) Sketch of the surface of the sample 7 (I) used for LOM the indicating positions of the micrographs

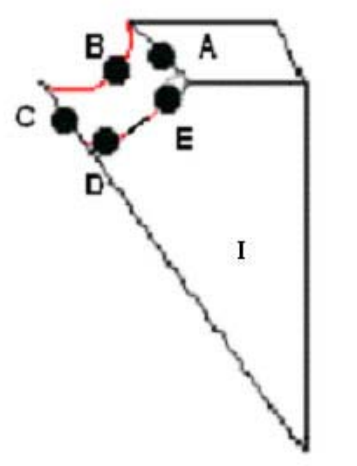

Figure 4.10 Light Optical Microscopy of the rod sample 3 according to the positions of the micrographs indicated in Figure $4.10 \mathrm{~F}$ 

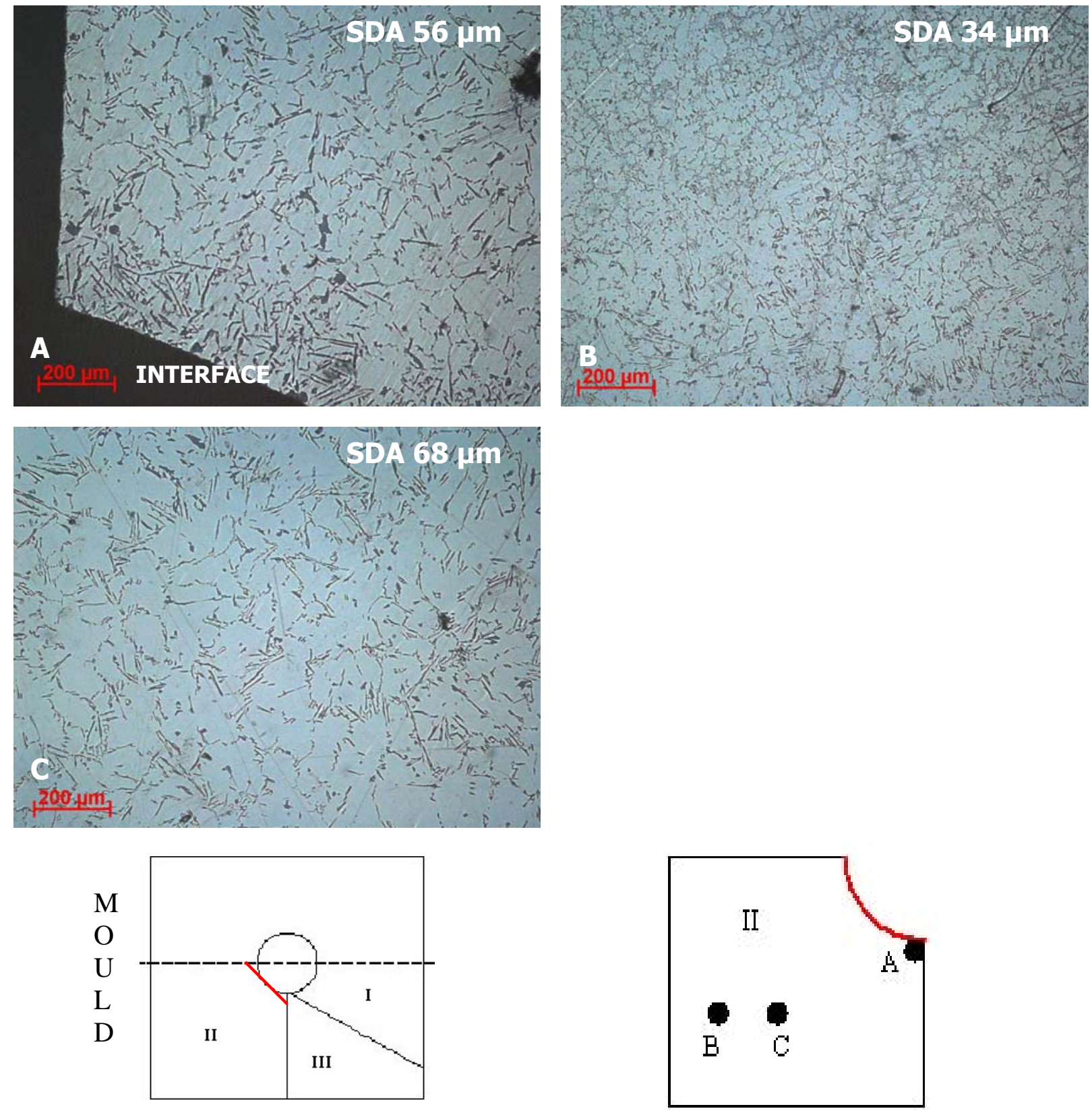

D) Sketch of the surface of the sample 7 (II) used for LOM the indicating positions of the micrographs

Figure 4.11 Light Optical Microscopy of the rod sample 3 according to the positions of the micrographs indicated in Figure 4.11 D

In Figure 4.11, we can observe the different microstructure in the section $A$ towards the insert. We can observe the changes of the structure looking at the size of the dendrite cell size. The SDA are changing from about $34 \mu \mathrm{m}$ at positions $B$ to about $70 \mu \mathrm{m}$ about $2 \mathrm{~mm}$ from the mould, as we can observe in Figure $\mathrm{C}$. The size of the dendrites is changing a few $\mathrm{mm}$ from the interface. The interface consists of the Al-Si eutectic. 
The next Figure 4.12 shows the microstructure of Al-Si casting in the section III. The interface A contains more of the Al-Si eutectic. The dendrite arm spacing measure

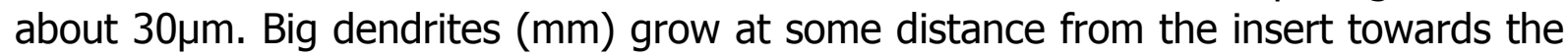
bulk. $\mathrm{C}$ shows a section of a primary dendrite stem with its brands. B shows mainly primary dendrite stems in parallel orientation.
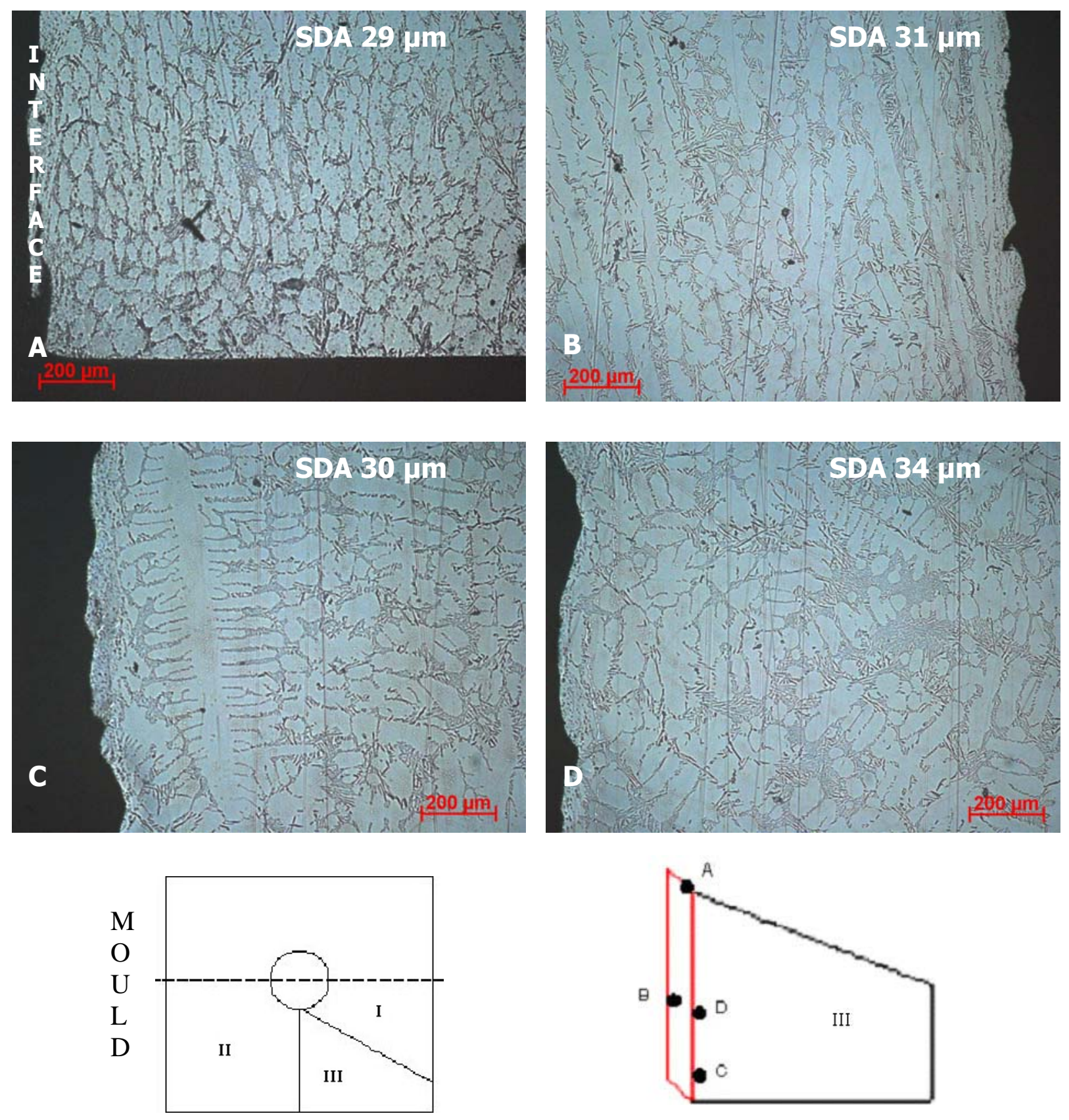

E) Sketch of the surface of the sample 7 (III) used for LOM indicating the positions of the micrographs

Figure 4.12 Light Optical Microscopy of the rod sample 3 according to the positions of the micrographs indicated in Figure $4.12 \mathrm{E}$ 


\section{- Cube samples}

In order to characterize the microstructure of the surface of the aluminium of the cube sample, the sample was ground and polished. Photomicrographs at small magnifications are shown in Figure 4.13, next to the interface. The interface consists of the Al-Si eutectic, with the dendrite arms spacing changing of about $60 \mu \mathrm{m}$ to $300 \mu \mathrm{m}(\mathrm{D})$. We can observe a dendrite structure with lots of porosity in between.
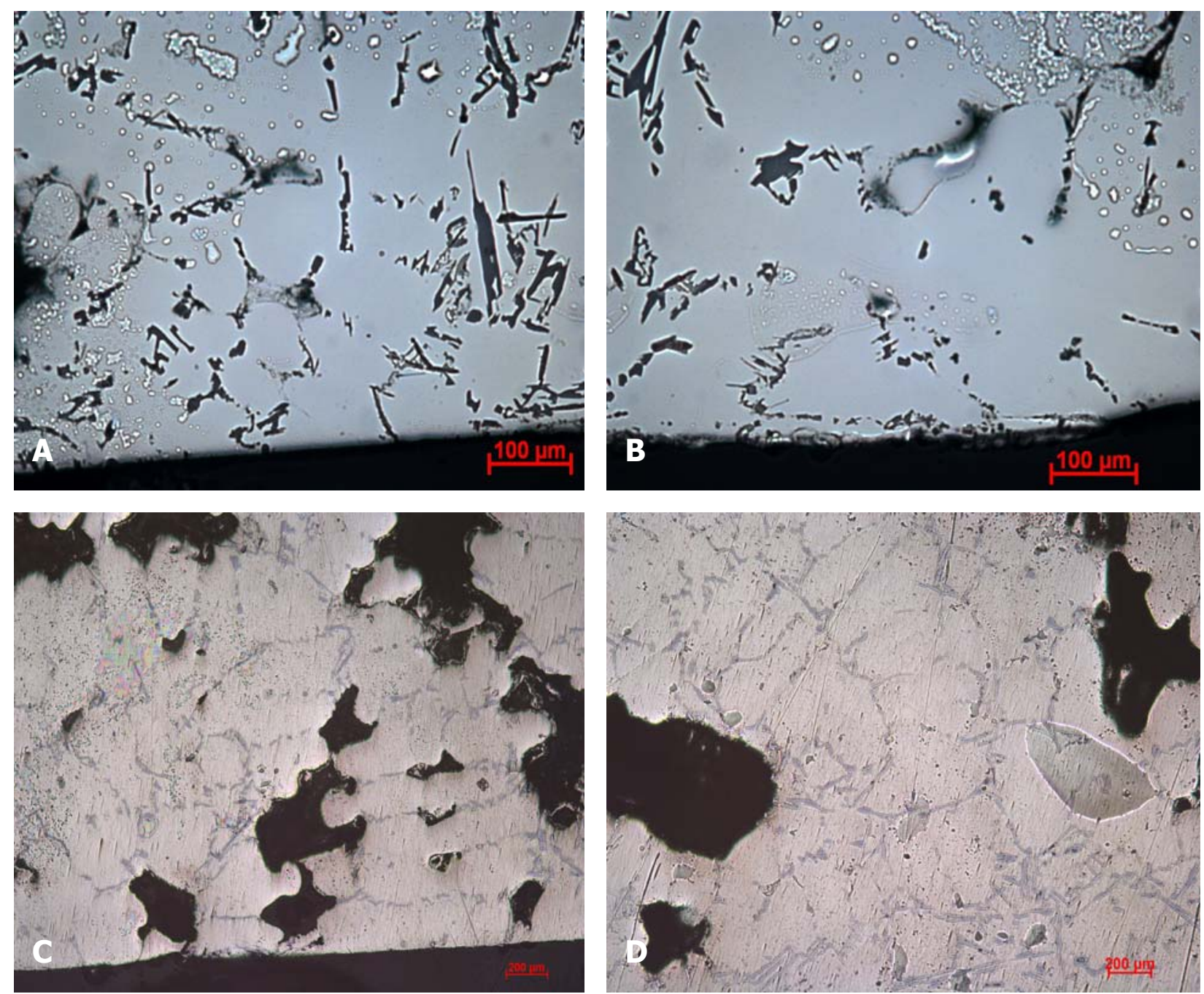

Figure 4.13 Microstructure of AlSi7Mg0.3 (cube sample)

\subsubsection{Low pressure die casting}

\section{- Step samples}

In Figure 4.14, we can see different microstructures of the Al-Si casting parallel to the step side surface of the casting process. We can observe the changes of the structure of the a-dendrites separated by the Al-Si eutectics along this plane. The size of the dendrite arm spacing is changing between 2 and $15 \mu \mathrm{m}$, which is caused 
by solidification rate differences at different positions. Discussing the interface to the insert (Figure $A, C, D, E$ ), a-dendrites measure $2-5 \mu \mathrm{m}$ in width. They are alternating with eutectic Al-Si12 in position A, and partly in E accumulating to about $20 \mathrm{vol} \%$. But in position $\mathrm{C}, \mathrm{D}$ the interface consists mainly of eutectic Al-Si12. Some $\mathrm{mm}$ away

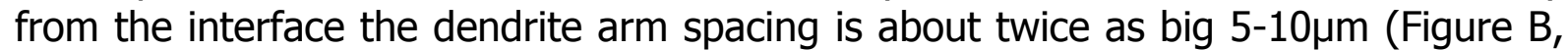
$\mathrm{G})$, and the volume fraction of the eutectic increases. The dendrite arm spacing is considerably bigger $(10-15 \mu \mathrm{m})$ in position $\mathrm{F}, \mathrm{H}$.

According to [1] the dendrite arm spacing (SDA) $<10 \mu \mathrm{m}$ corresponds to $<50 \mathrm{~K} / \mathrm{s}$ solidification rates. Positions Figure $4.15 \mathrm{~F}, \mathrm{H}$ may result from $20-40 \mathrm{~K} / \mathrm{s}$ solidification rate.
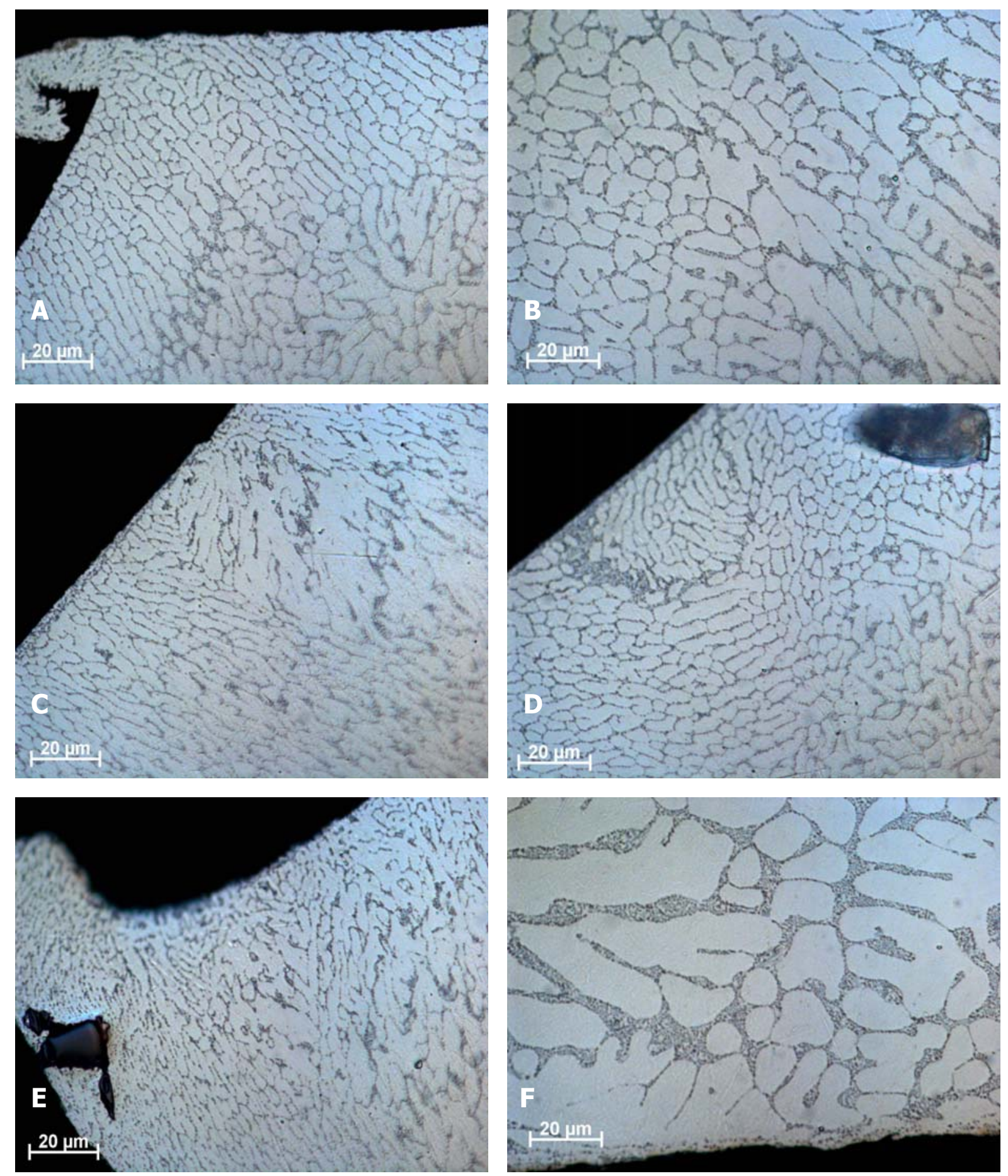

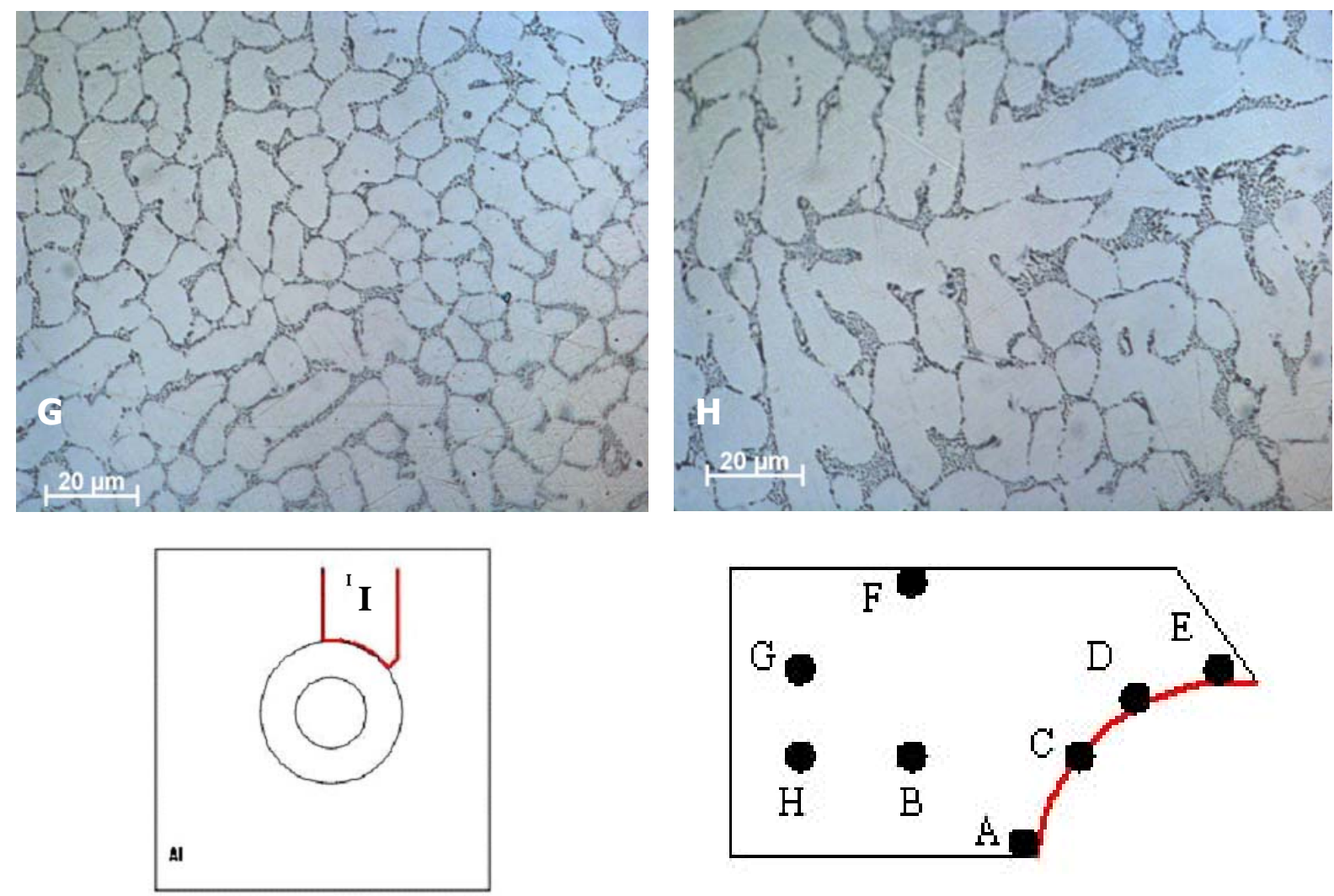

K) Sketch of the surface of the step sample 10 used for LOM indicating the positions of the micrographs $2 \mathrm{~mm}$ below the surface

Figure 4.14 Light Optical Microscopy of the step sample 10 according to the positions of the micrographs indicated in Figure $4.14 \mathrm{~K}$

The positions of the micrographs in Figure 4.15 along the steel inserts height are indicated in position $A$. The interface areas close to the step side surface of the casting consist mainly of an $\alpha$-seam less than $10 \mu \mathrm{m}$ thick and about $0.1 \mathrm{~mm}$ wide (C, E) followed by fine structured dendrites of $\mathrm{ca}$. $2 \mu \mathrm{m}$ in width. The microstructure corresponds somewhat to that in Figure $D$, but is finer than that in Figure $C$ resulting from $<50 \mathrm{~K} / \mathrm{s}$ solidification rate. In the centre of the thickness of the sample (B), the dendrites increase to more than $20 \mu \mathrm{m}$ corresponding to about $5 \mathrm{~K} / \mathrm{s}$ solidification rate. A few $\mathrm{mm}$ away from the insert similar coarse dendrites are found in Figure $B$; somewhat finer close to the surface in positions $D, F$. 

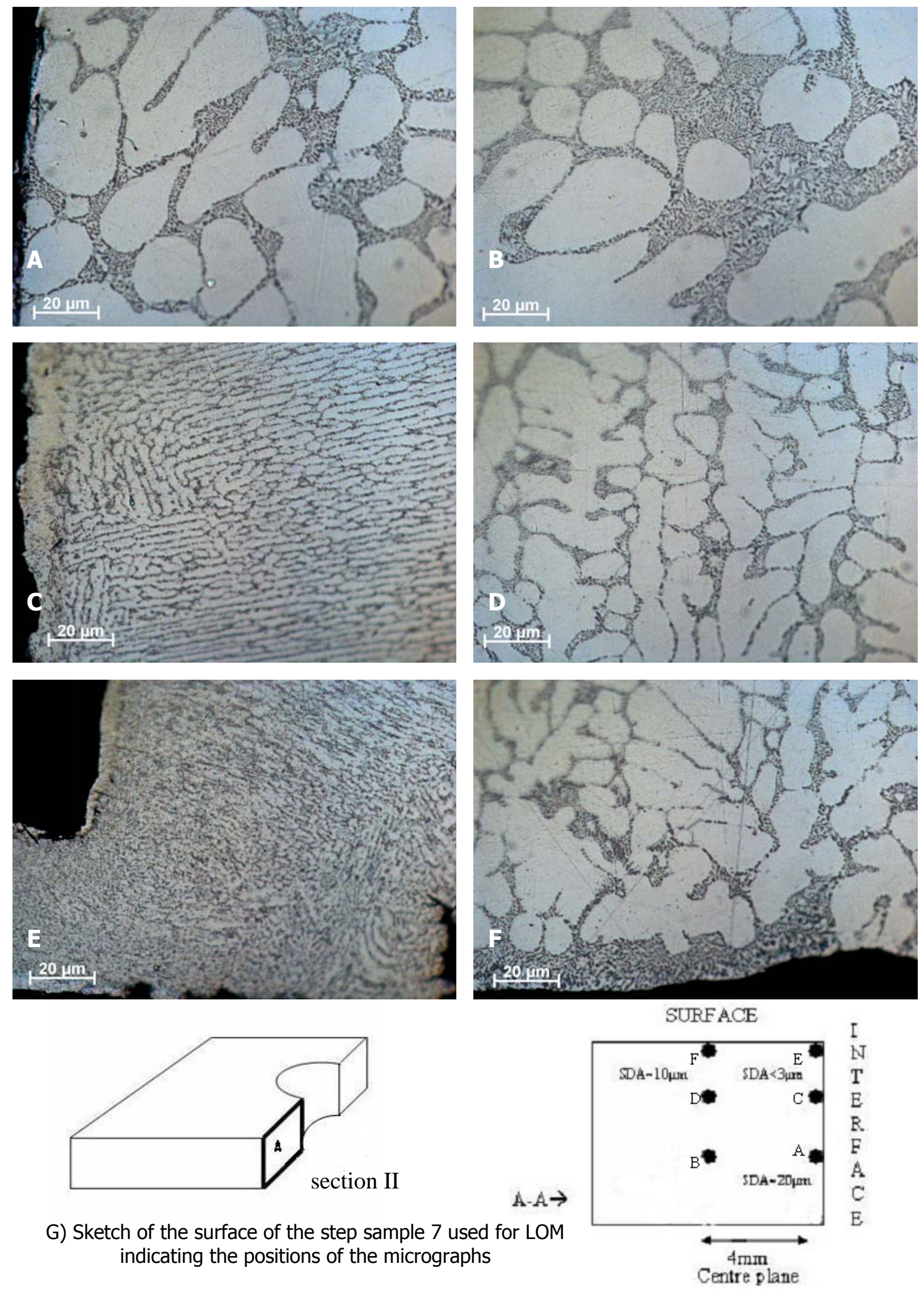

Figure 4.15 Light Optical Microscopy of the step sample 7 according to the positions of the micrographs indicated in Figure $4.15 \mathrm{G}$ 
Photomicrograph (Figure 4.16) at small magnification shows quite normal structure, with the dendrite arm spacing of about $12 \mu \mathrm{m}$.
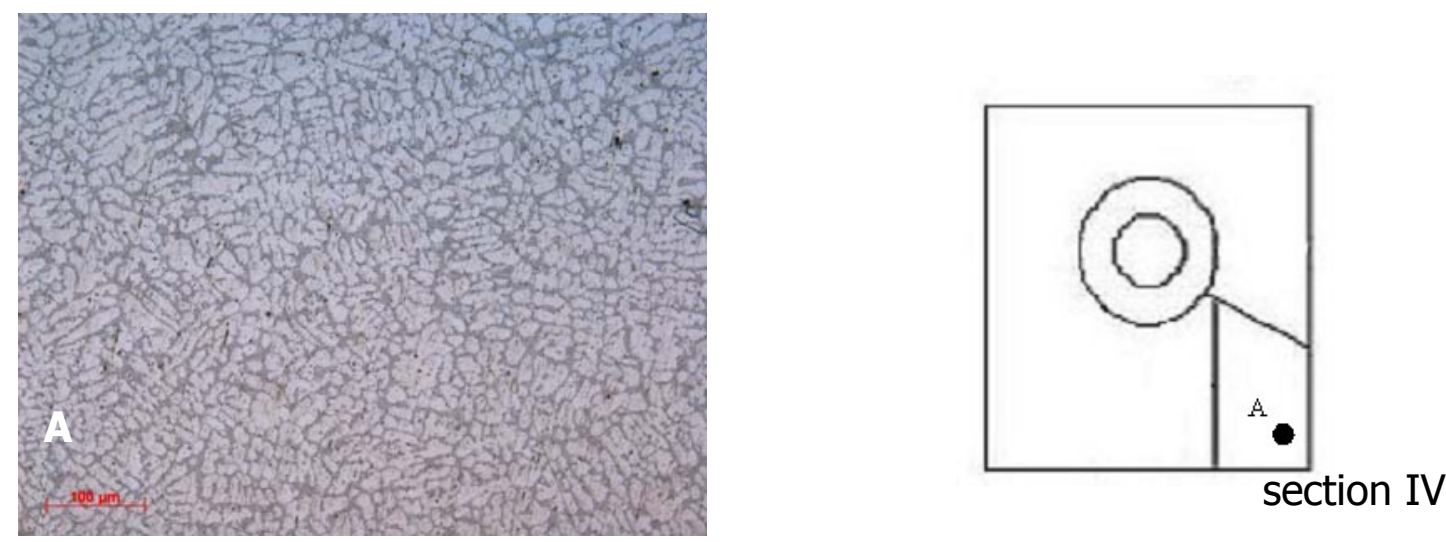

Figure 4.16 Light Optical Microscopy of the step sample 2

Figure 4.17 and 4.18 shows the structure of the Al-Si casting towards the interface. Discussing the interface to the insert, the a-dendrites measure $2-5 \mu \mathrm{m}$ in width. Positions B, C show increased eutectic zones at the bonded interface section. The dendrite cells are showing the finest structure, with the dendrite size much smaller $(4 \mu \mathrm{m})$ than close to surface where the cells measured about $10 \mu \mathrm{m}$. The grain size increases towards the interior of the casting. The internal structure we can observe in Figure $4.18 \mathrm{E}$, where the dendrite arms measure about $10 \mu \mathrm{m}$. Some porosity is observed.

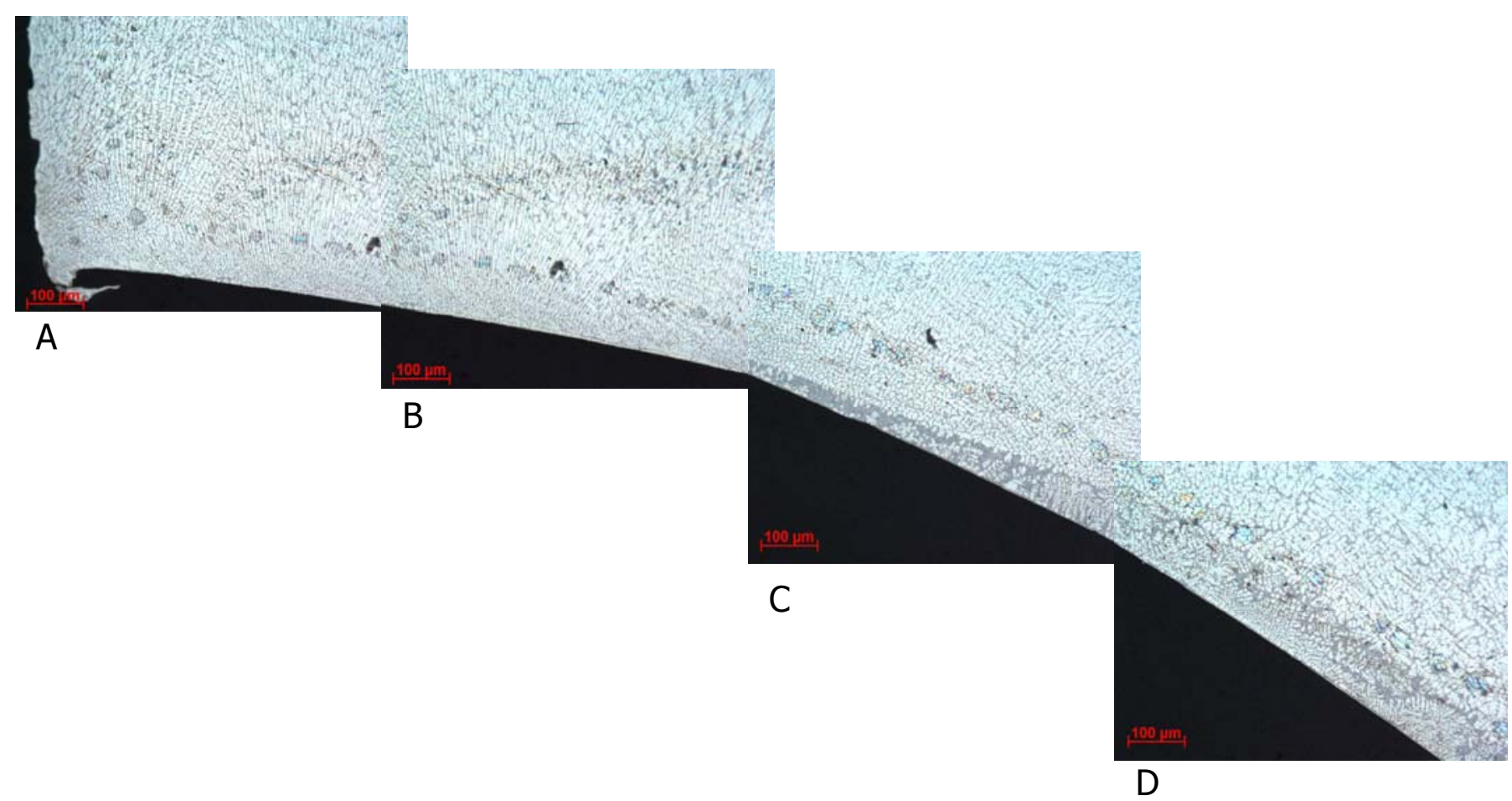

Figure 4.17 Composed Light optical micrographs of the step sample 2 at the interface towards the steel insert 1-2 mm below the surface (depicts see Figure 4.18) 

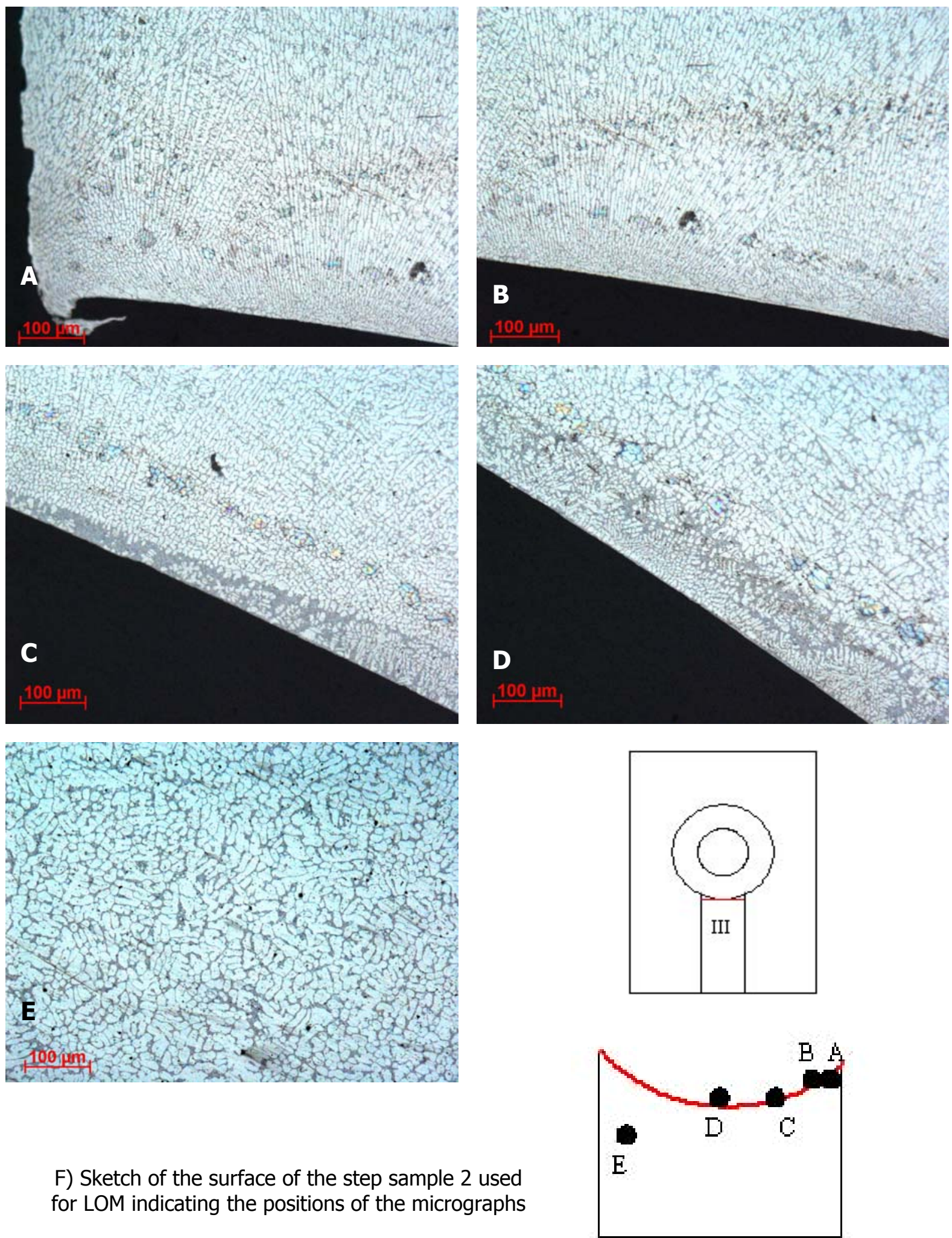

for LOM indicating the positions of the micrographs

Figure 4.18 Light Optical Microscopy of the step sample 2 according to the positions of the micrographs indicated in Figure $4.18 \mathrm{~F}$ 
In Figure 4.19 and in 4.20 , we see different microstructures of the casting next to the interface. We can observe the changes of the structure looking at the size of dendrite arms. The interface consists mainly of Al-Si eutectic, as we see in position A. The dendrite arms spacing of about $3 \mu \mathrm{m}(\mathrm{A})$ to about $10 \mu \mathrm{m}(\mathrm{C}, \mathrm{D})$ are observed.
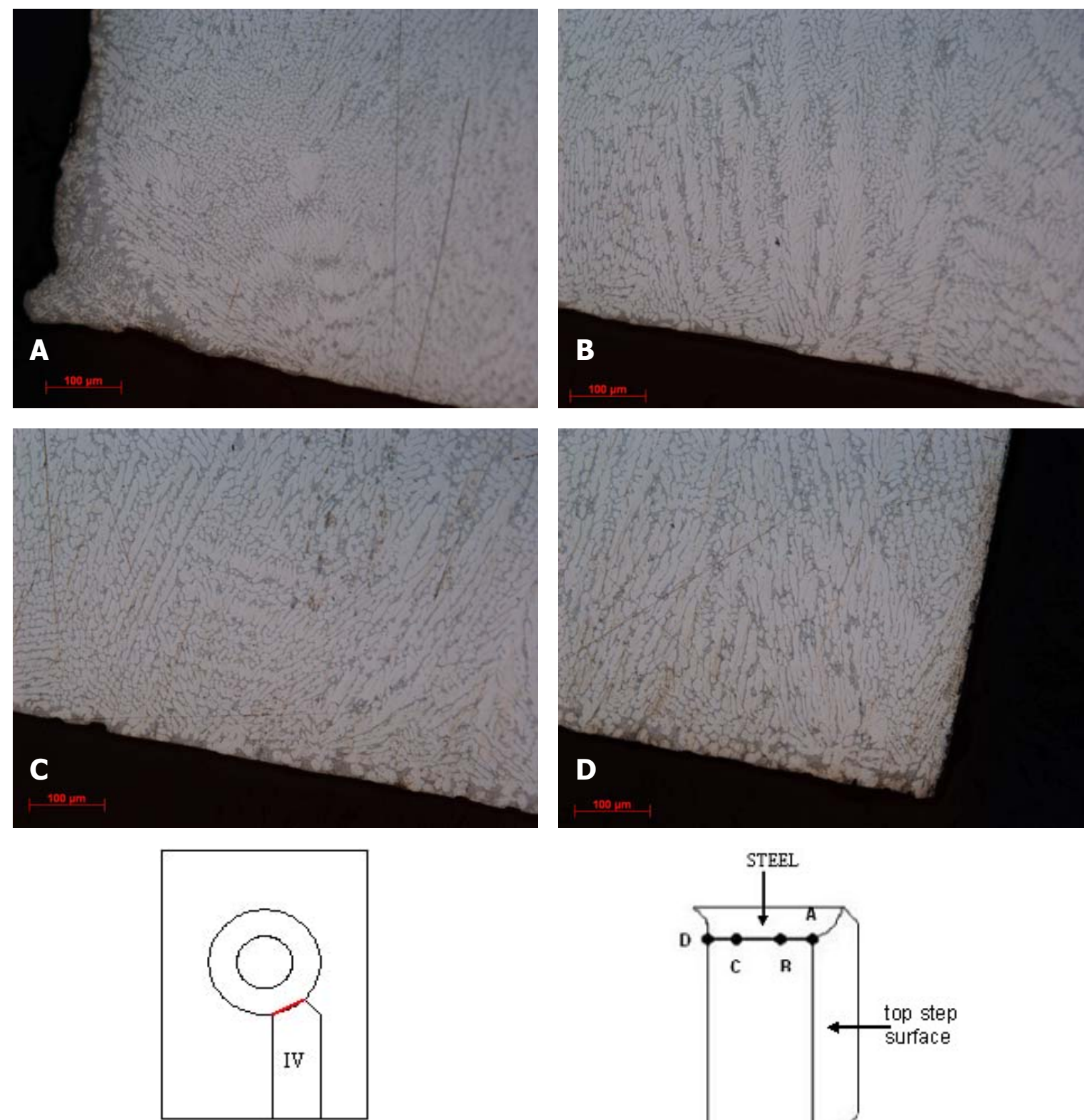

E) Sketch of the surface of the step sample 2 used

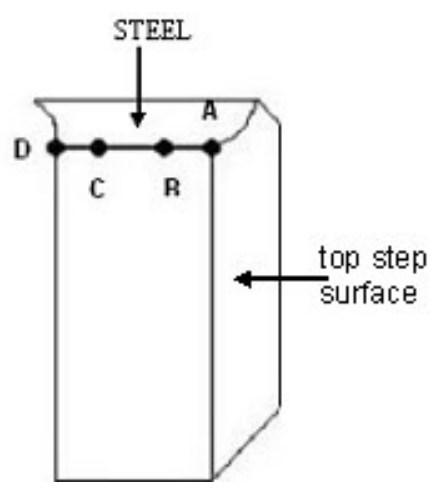
for LOM indicating the positions of the micrographs

Figure 4.19 Light Optical Microscopy of the step sample 2 according to the positions of the micrographs indicated in Figure $4.19 \mathrm{E}$ 


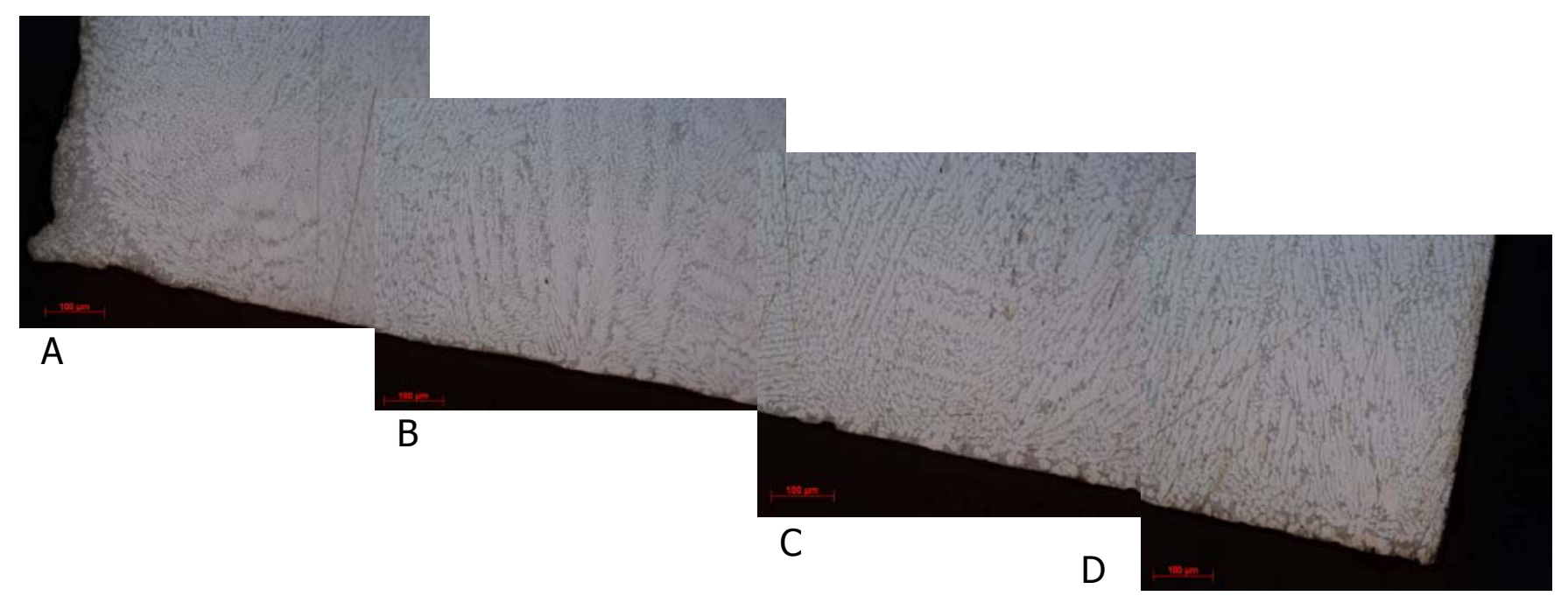

Figure 4.20 Composed micrographs of Figure 4.19 of the step sample 2

\subsubsection{Squeeze casting}

\section{- Demo-axial samples}

The structure of the bulk AlSi7Mg0.3-casting is shown in Figure 4.21 with dendrite arm spacing changing from about $24 \mu \mathrm{m}$ (b) to about $30 \mu \mathrm{m}$ in the position A with some eutectic between. The finest structure we can observe in the position $\mathrm{C}$ with dendrite size of about $10 \mu \mathrm{m}$.

Figure 4.22 shows the microstructure of the sample after heat treatment of $165^{\circ} \mathrm{C} / 2.5 \mathrm{~h}$ and after pull out test (see Figure 4.67). The dendrite cells are a bit smaller than we can observe in other as cast positions.

In Figure 4.23 the microstructure of the sample with $350^{\circ} \mathrm{C} / 2 \mathrm{~h}$ thermal condition (used for pull out test) consists of large regions $(\sim 0.5 \mathrm{~mm})$ of the eutectic Al-Si, with the dendrites between $15-42 \mu \mathrm{m}$. At the position A the dendrites are bigger, growing up to $40 \mu \mathrm{m}$ with more eutectic between.
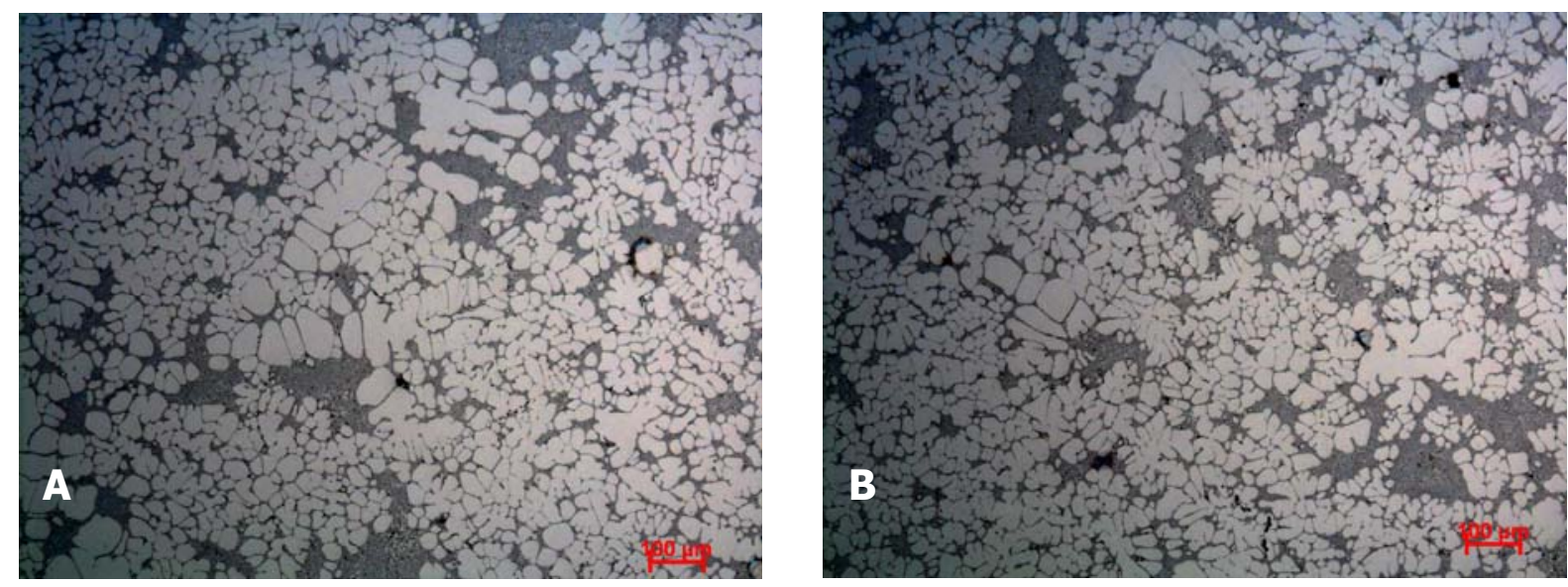


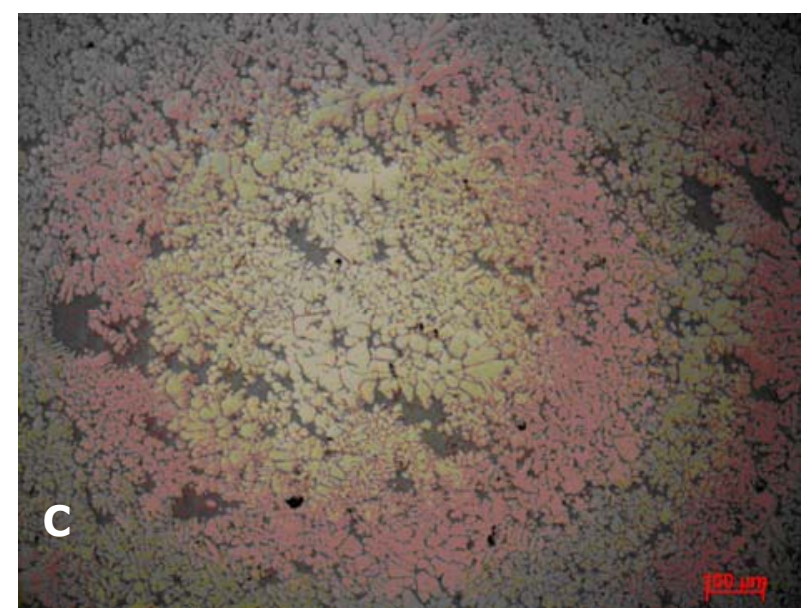

Figure 4.21 Bimodal SDA of the demo-axial sample (AlSi7Mg0.3)
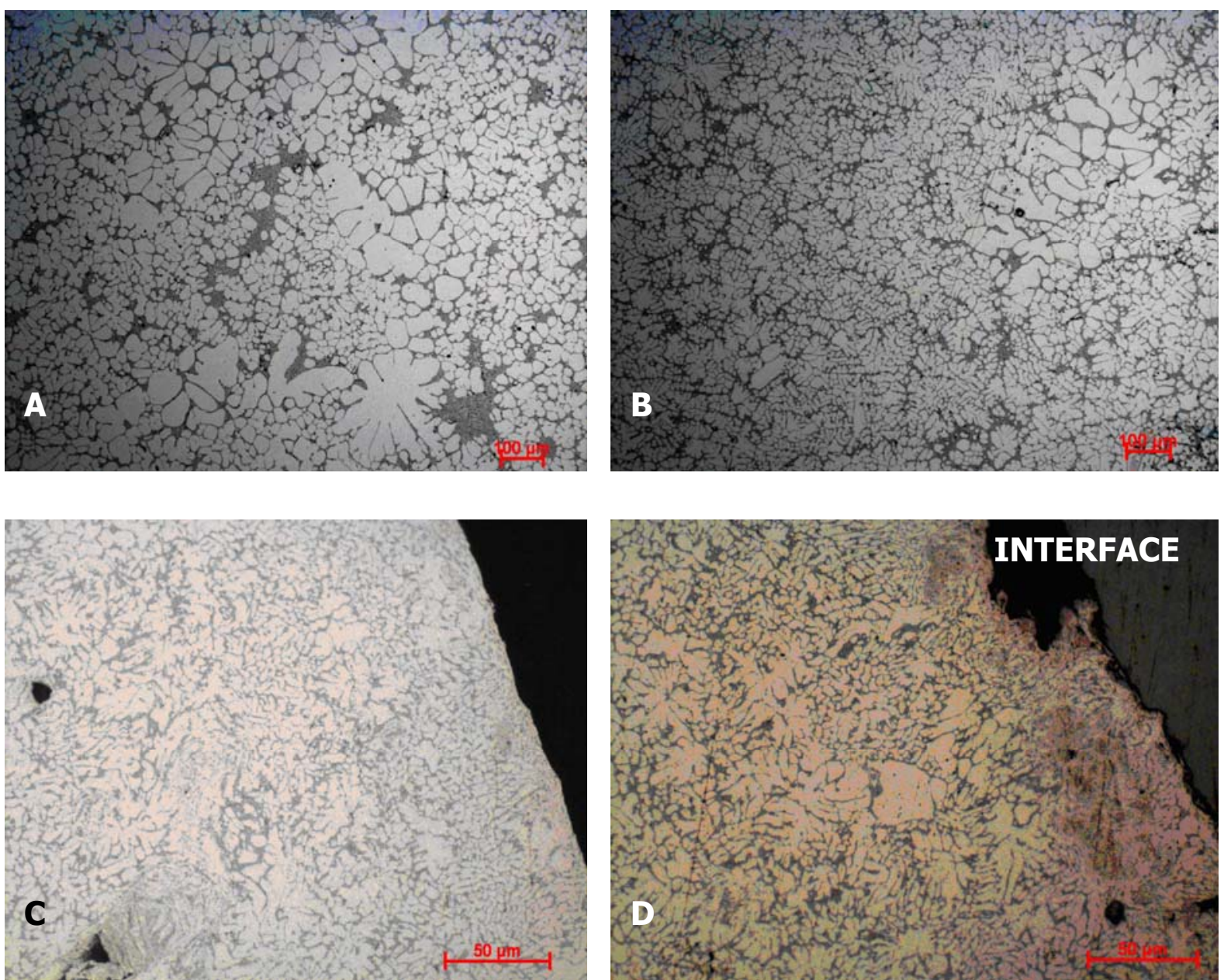

Figure 4.22 Micrographs of the demo-axial sample after tensile test (heat treatment $165^{\circ} \mathrm{C} / 2.5 \mathrm{~h}$ ) 

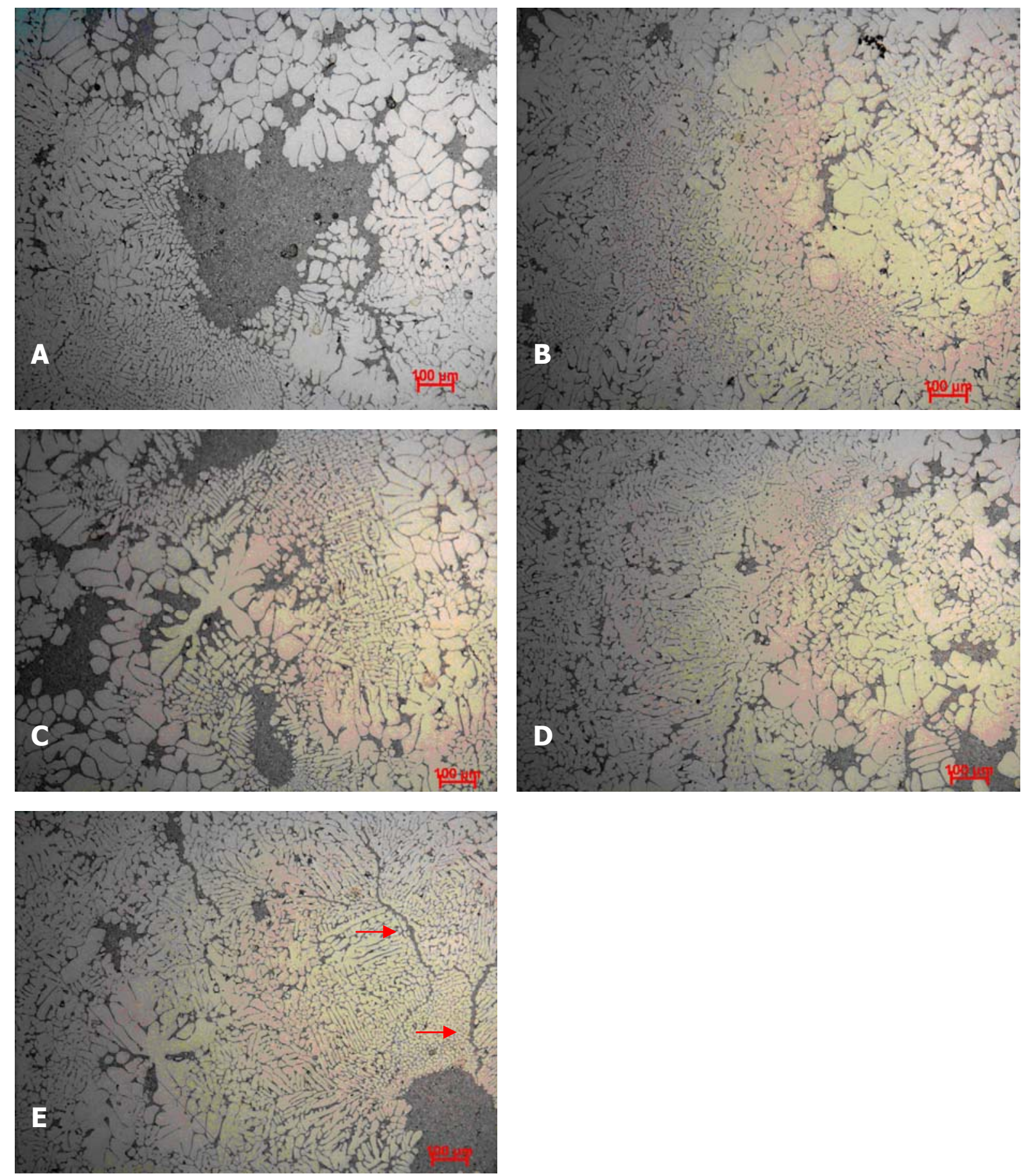

Figure 4.23 Micrographs of bimodal structure of the demo-axial sample after tensile test (heat treatment $350^{\circ} \mathrm{C} / 2 \mathrm{~h}$ ), bimodal SDA $10 \mu \mathrm{m} / 50 \mu \mathrm{m}$ 


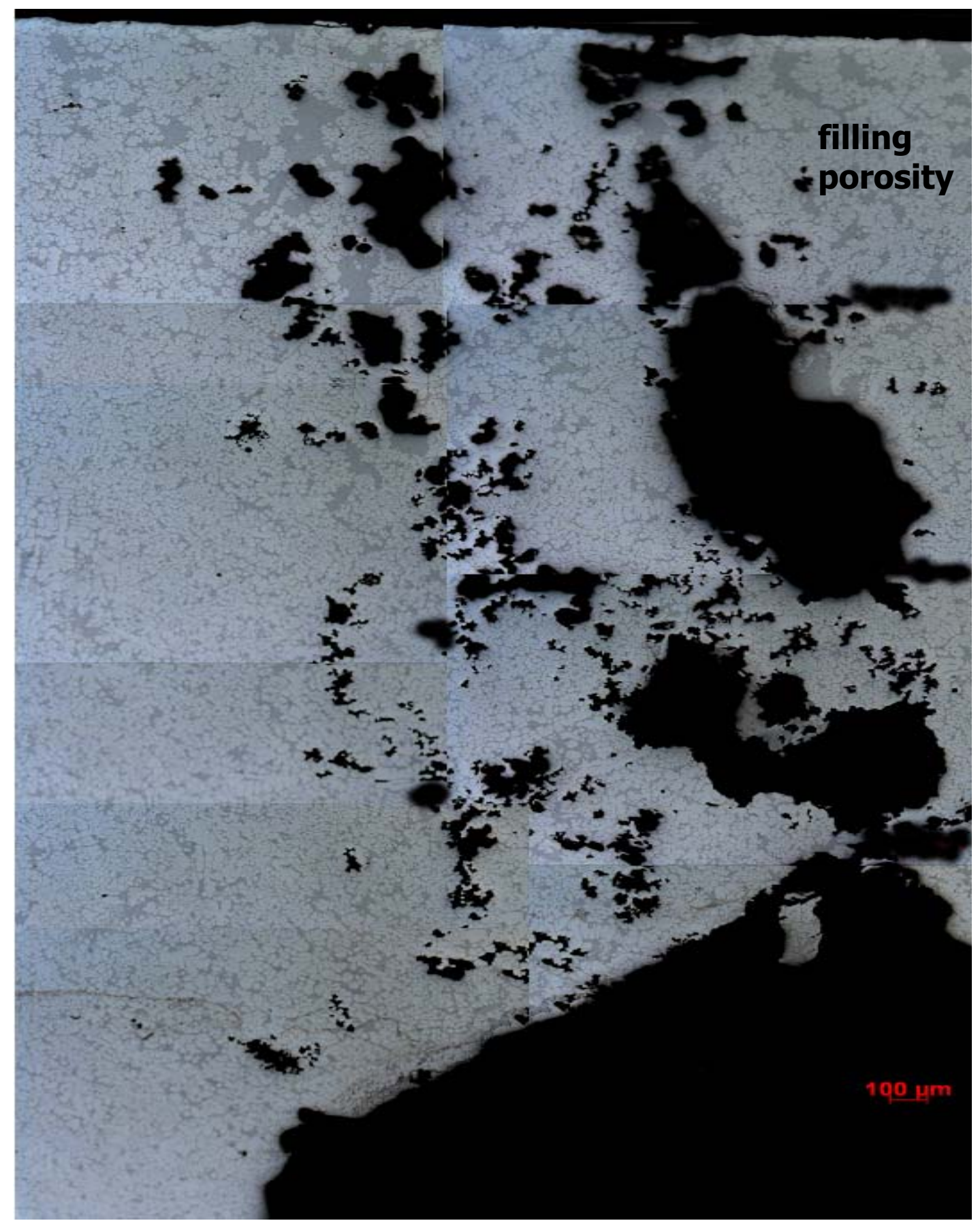

Fig. 4.24 LOM of the demo-axial sample showing the gap in the middle of the bulk of the casting in the marked region of Figure $4.74 \mathrm{~A}$

The structure of the bulk aluminium with defects of the squeeze casting process is shown in Figure 4.24. The dendrites arm spacing changes from less than $10 \mu \mathrm{m}$ to about $30 \mu \mathrm{m}$. The structure consists mainly of eutectic, with increasing eutectic zones towards the gap. Such a gap could be formed by lack of filing of the solidified dendritic structure. The sample was used for laser ultrasound measurements (see Figure $4.74 \mathrm{~A}$ ), which shows the position of the defect. 


\subsubsection{Interface gaps, shrinkage pores, dendrites}

In order to characterize the shrinkage of the Al along the steel insert we used rod sample. The sample was cut in the middle of the length into two halves, ground and polished perpendicular to the insert axis along the centre plane.

Photomicrographs at small magnifications are shown in Figure 4.25. We can see the different microstructures of the casting next to the steel insert. We can observe the

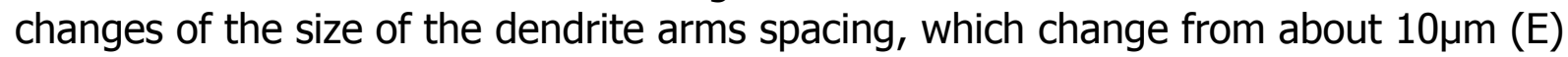
to about $50 \mu \mathrm{m}(\mathrm{G})$. Si segregation with primary Si we can observe in position $\mathrm{E}, \mathrm{F}, \mathrm{G}$.
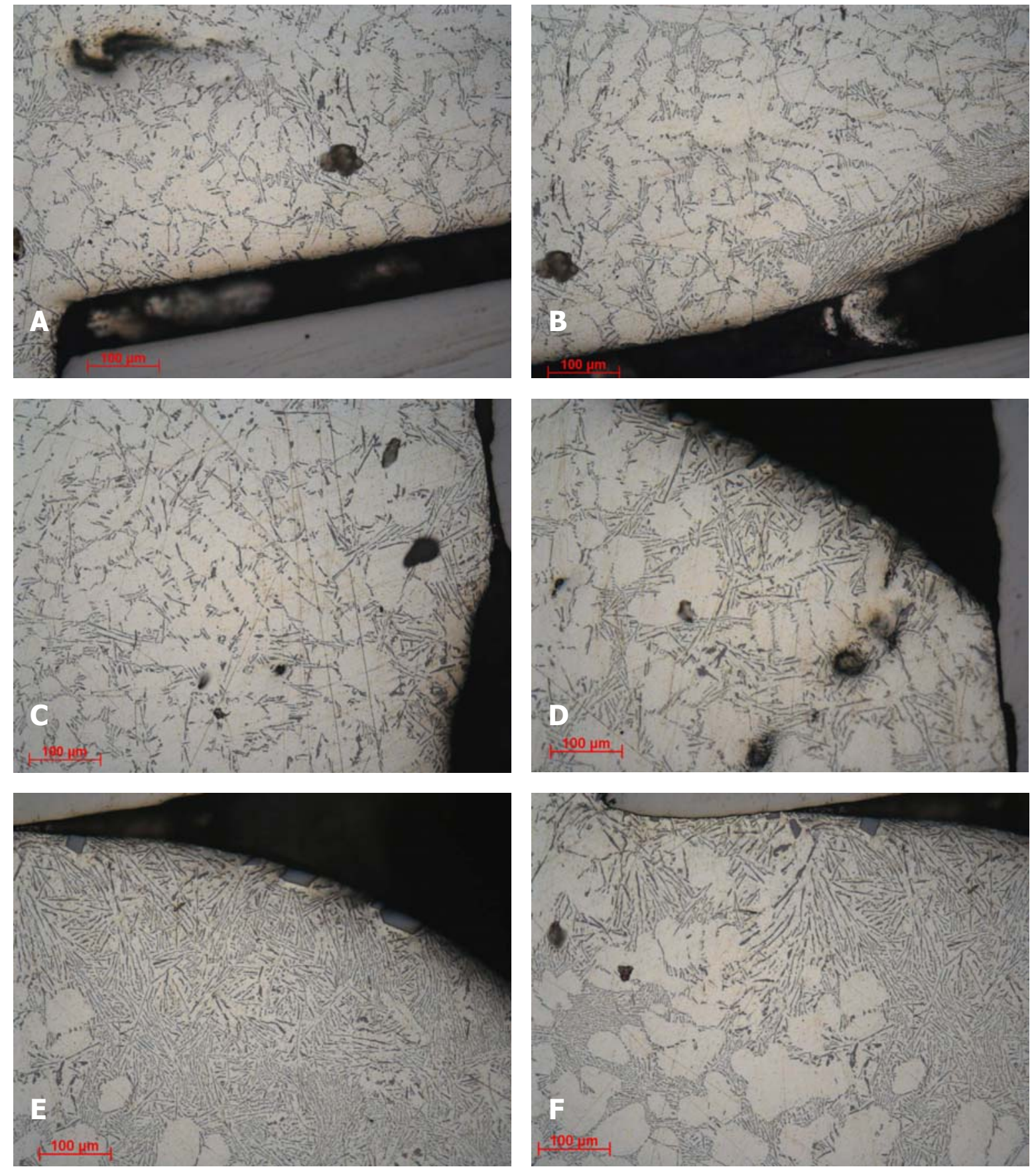

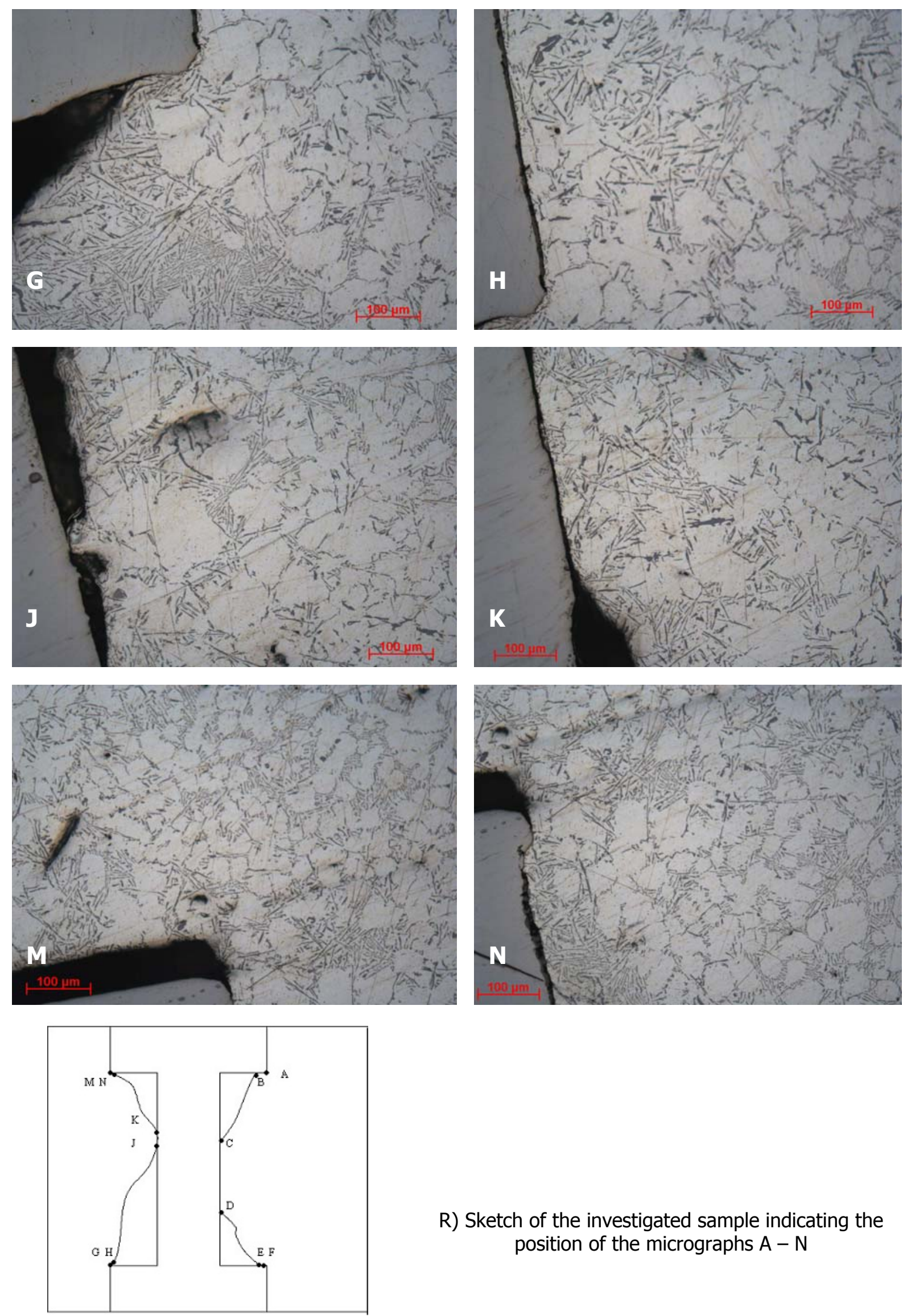

R) Sketch of the investigated sample indicating the position of the micrographs $\mathrm{A}-\mathrm{N}$

Figure 4.25 LOM of the rod sample 2 according to the positions indicated Figure $4.25 \mathrm{R}$ 
Micrographs 4.26 A, B showing a defect with micro-pores within the Al of the sample may be assigned to hot tearing.
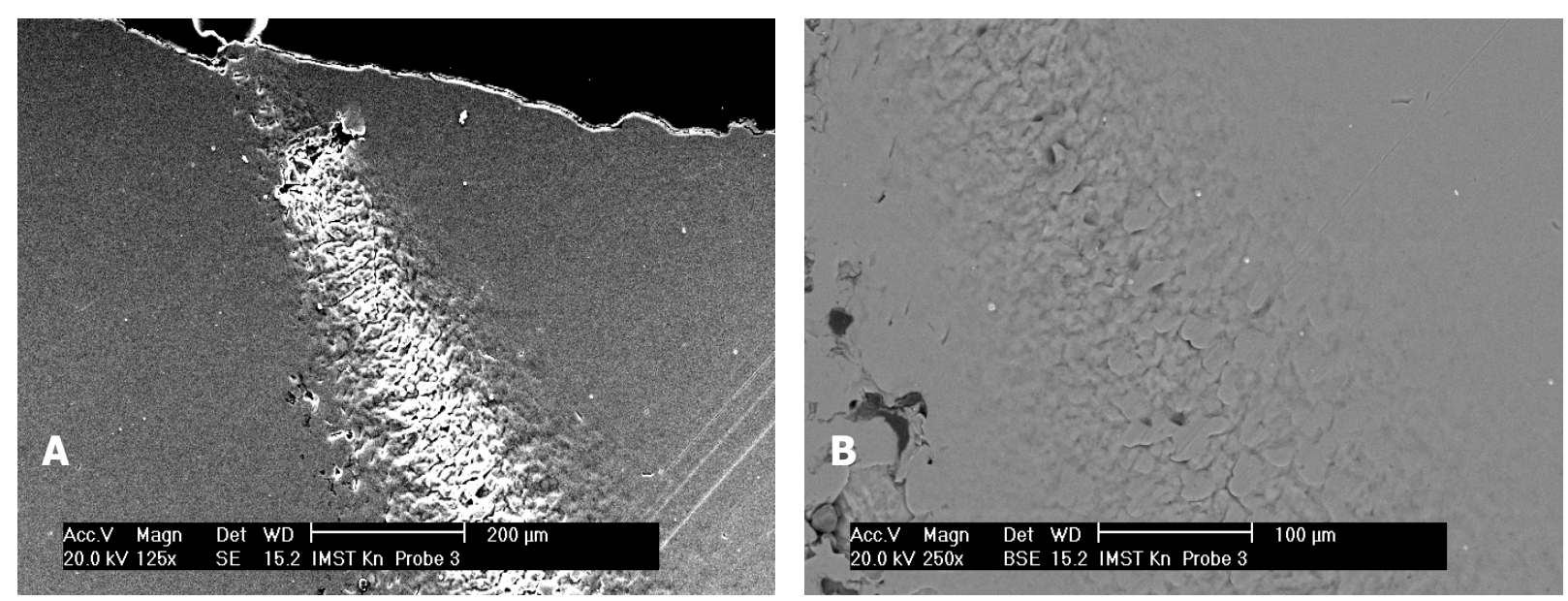

Figure 4.26 SEM micrographs showing a defect with micro-pores within the Al of the cube sample 1

Figure 4.28 shows the bonding between steel and Al of the cube sample 1 . The interface between the steel insert and casting part is damaged and broken. Lots of porosity is observed. Discussing the interface and surface, the pores measure between $0.1-0.9 \mathrm{~mm}$ in width (Figure 4.27). In some places $4.27 \mathrm{~B}$ the bonding looks much better than in the sample 2, but we can see lots of cracks next to the interface (Figure 4.28), with the length of the cracks changing from about $100 \mu \mathrm{m}$ to about $200 \mu \mathrm{m}$.
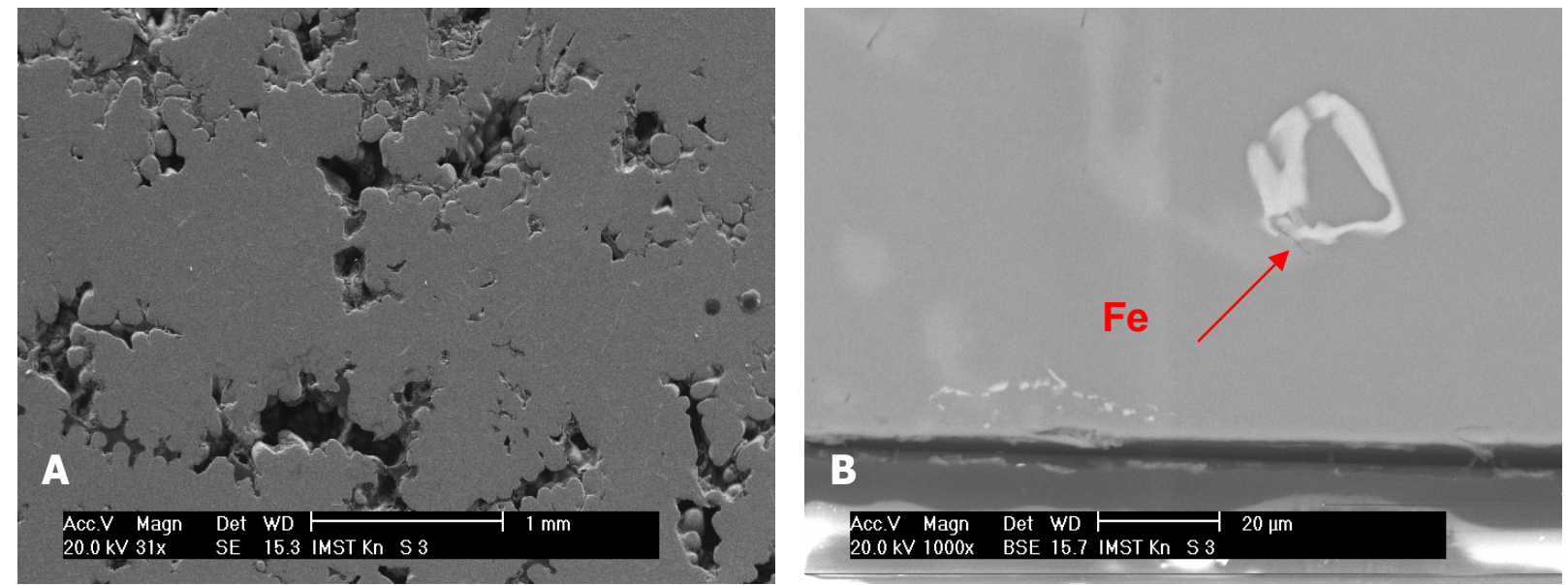

Figure 4.27 SEM micrographs of the cube sample 3 (AlSi7Mg0.3 / mould $700^{\circ} \mathrm{C}$ ) showing filling porosity 

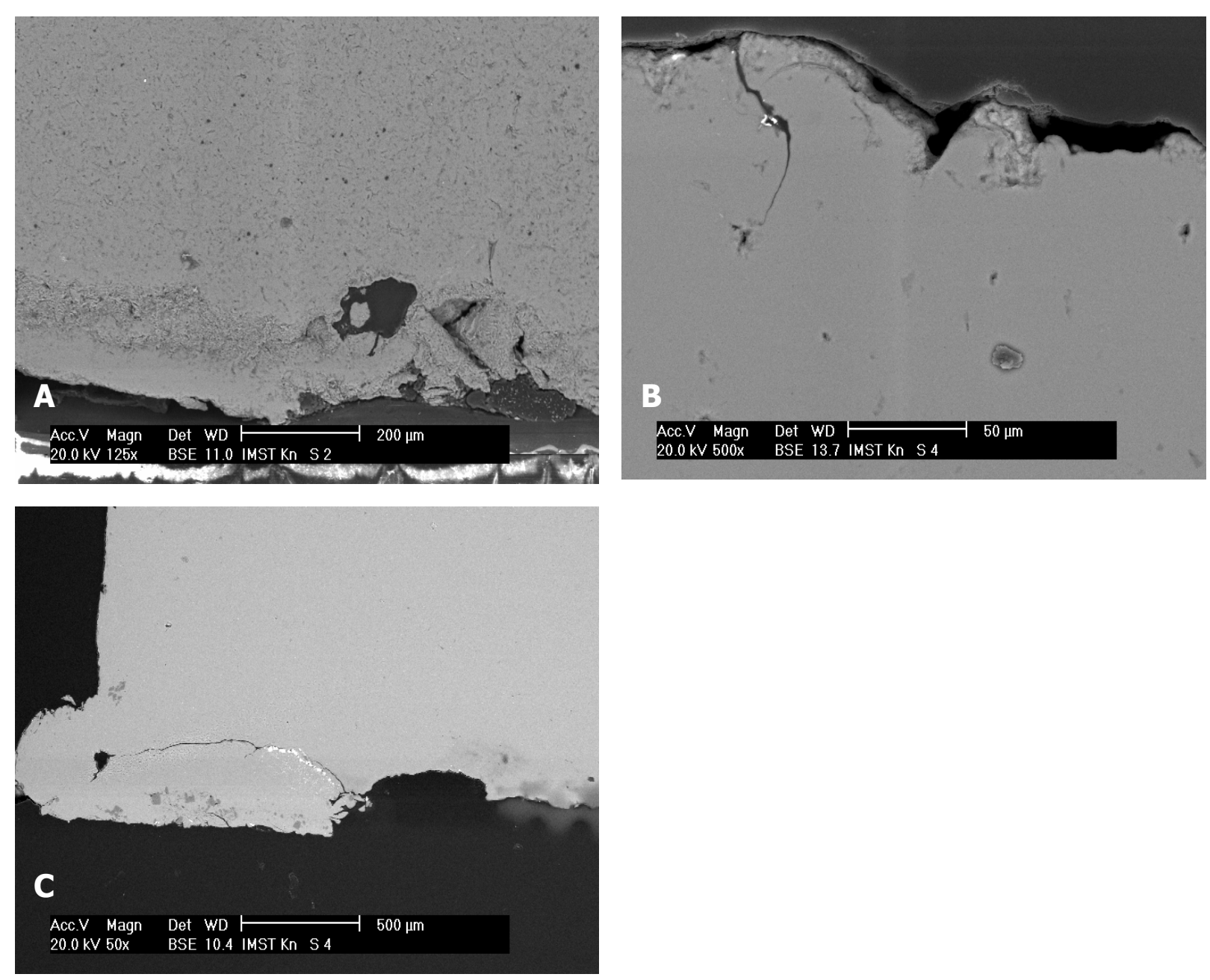

Figure 4.28 SEM micrographs of the cube sample 2 (Al/ mould RT) A) shows the structure and bonding between the steel insert and aluminium, B, C) shows cracks at the interface, parts of the edges are broken away (may stick to the insert) 


\subsubsection{Interface observation}

The interesting part was a difference in the thickness of the sample 10 as between the Al overflow rim ( $<1 \mathrm{~mm}$ over the steel insert) and the Al bulk close to the insert. For this part of experiments we used the optical microscopy, as the micrometer screw was not enough precise. We measured the region where Al overflows the steel. We tried to know the step height and the deformation with respect to the Al bulk which shrank due to thermal expansion difference $\Delta \mathrm{a}$ where that of $\mathrm{Al}$ is twice as big as that of steel. $\Delta \mathrm{T}$ is taken to be $550 \mathrm{~K}$.

$\Delta \mathrm{a} \Delta \mathrm{T}=12 \cdot 10^{-6} \cdot 550=0.66 \%$, which gives for $15 \mathrm{~mm}$ height $0.1 \mathrm{~mm}$ shrinkage difference.

The average shrinkage between $\mathrm{Al}$ bulk and overflow rim is about $50 \mu \mathrm{m}$. The relative shrinkage should amount to about $0.1 \mathrm{~mm}$, which corresponds very well when assuming the $50 \mu \mathrm{m}$ step on both sides. The shrinkage can be observed already less than $2 \mathrm{~mm}$ from the border of the insert. Figure 4.31 shows a SEM micrograph of the overflow of Al over the steel insert.

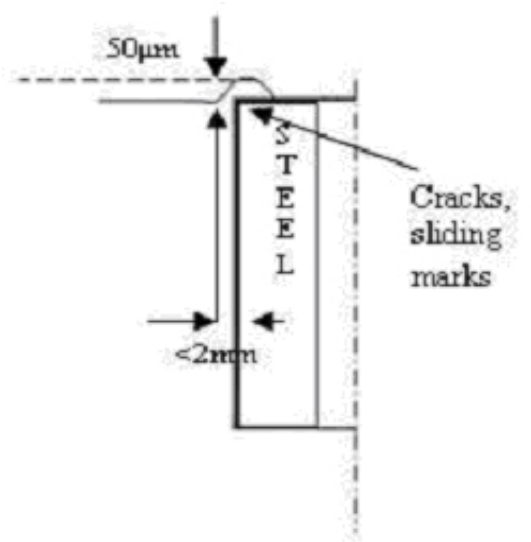

Figure 4.29 Sketch of the deformation along the axis of the steel insert

The sample was cut in the middle of the thickness, perpendicular to the insert axis into two equivalent halves. The half with the overflow rim was cut along a plane parallel to insert's axis roughly through the points 2-9 (Figure 4.30). We supposed that the rest of the steel cylinder would fall out of the Al by itself, but it didn't. It sticks. Without applying any force we decided to cut the sample again more or less perpendicular through point 6 . The sample fell apart. In the next part of experiments we used sample 7, which was cut in the same way as sample 10. This sample also stuck till the last cut. The bending between the insert and the surrounding casting (in both samples) was strong enough to sustain all the cutting procedures.

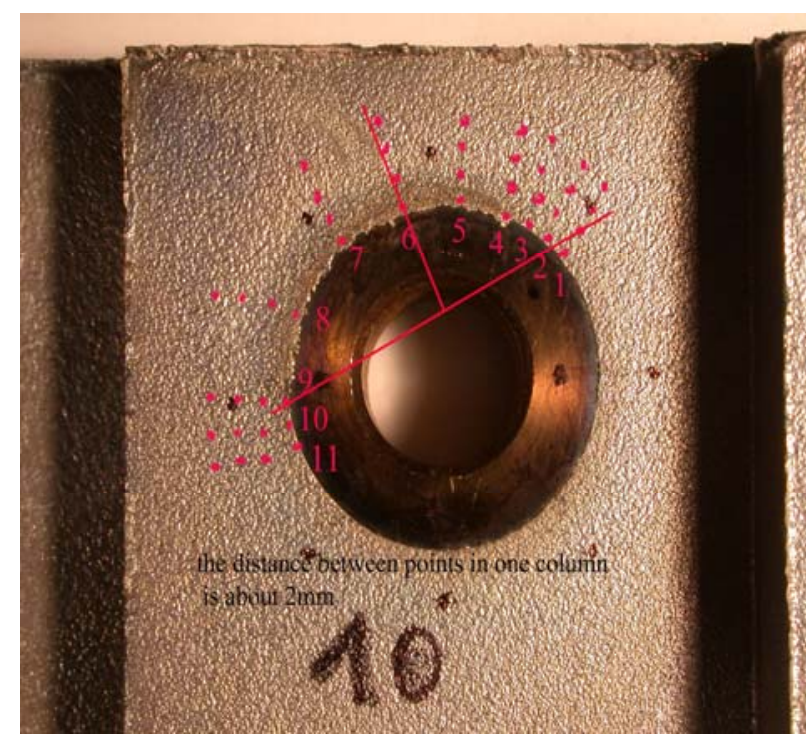

Figure 4.30 The distance between points in one column is about $2 \mathrm{~mm}$. Cutting are marked by red lines 


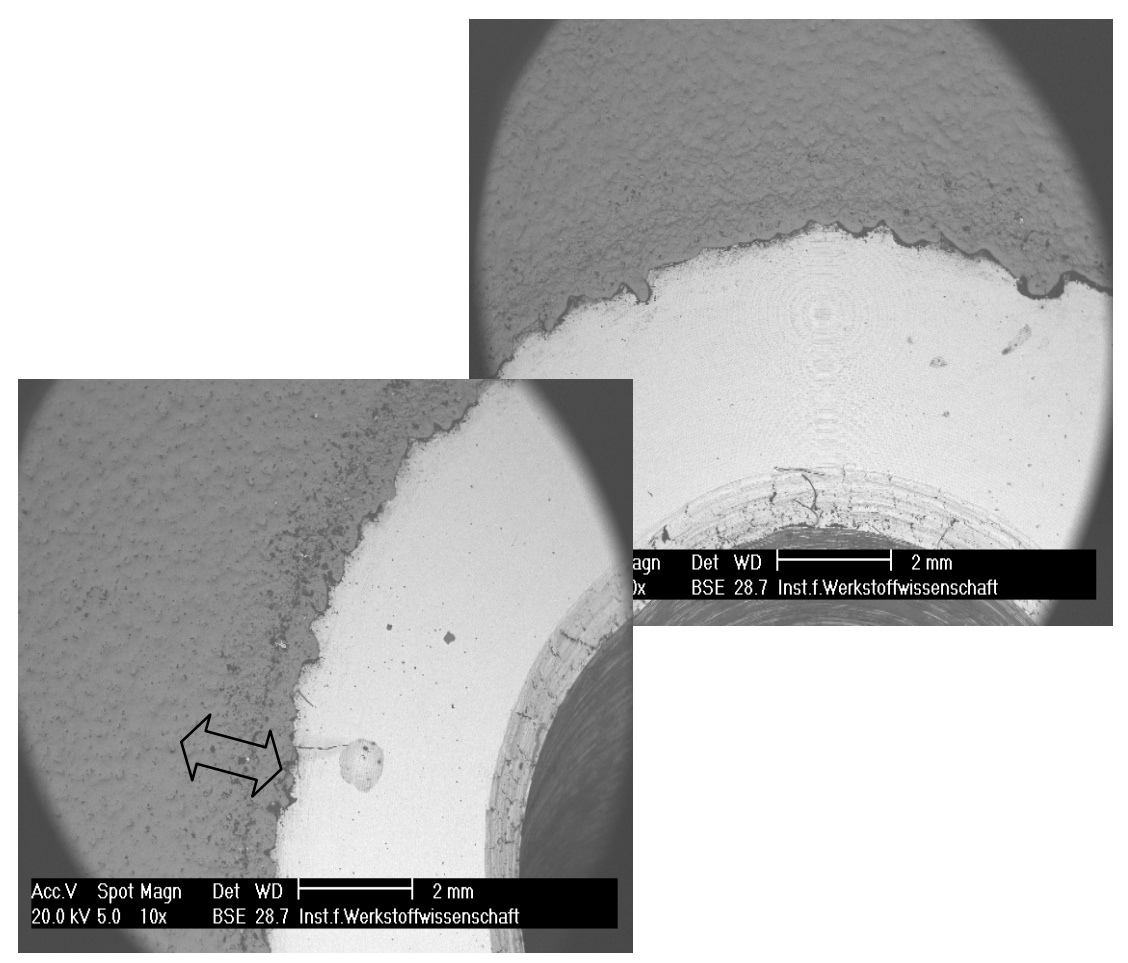

Figure 4.31 Top view of the section of Al overflow rim over the steel insert (SEM micrographs, step sample 10). Arrow indicates the width of the deformed Al-surface

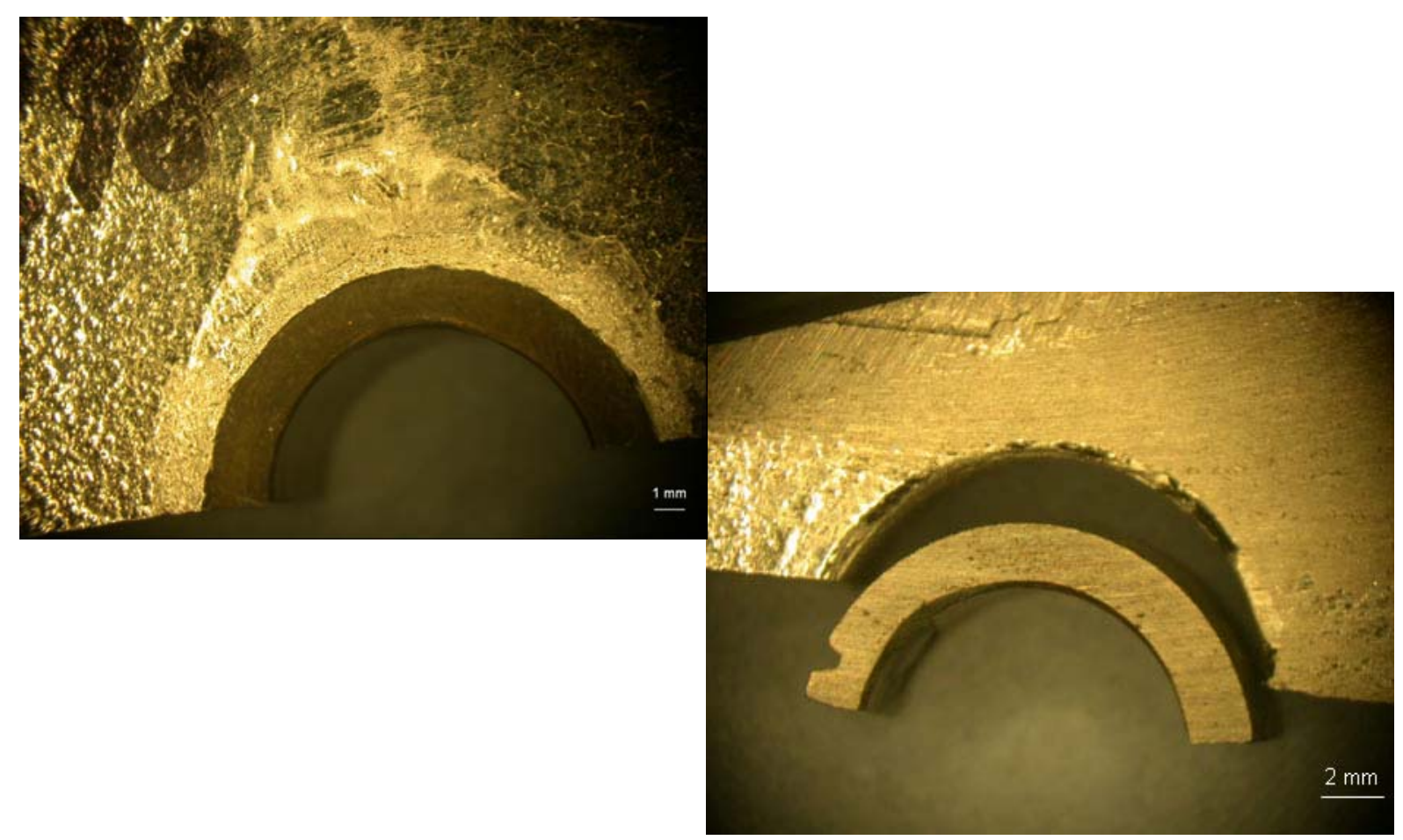

Figure 4.32 Steel insert fell apart during cutting through the points 2-9 (see Figure 4.30) 
The SEM micrographs (Figure $4.33 \mathrm{~A}, \mathrm{~B}$ ) show the cracks and reaction products in the cast part of the sample. For this part of the experiments we used sample 10 $(15 \mathrm{~mm})$ and sample $7(25 \mathrm{~mm})$. In sample 7 we did not find any cracks but we found lots of dendritic shrinkage porosity what we can see in the position D.
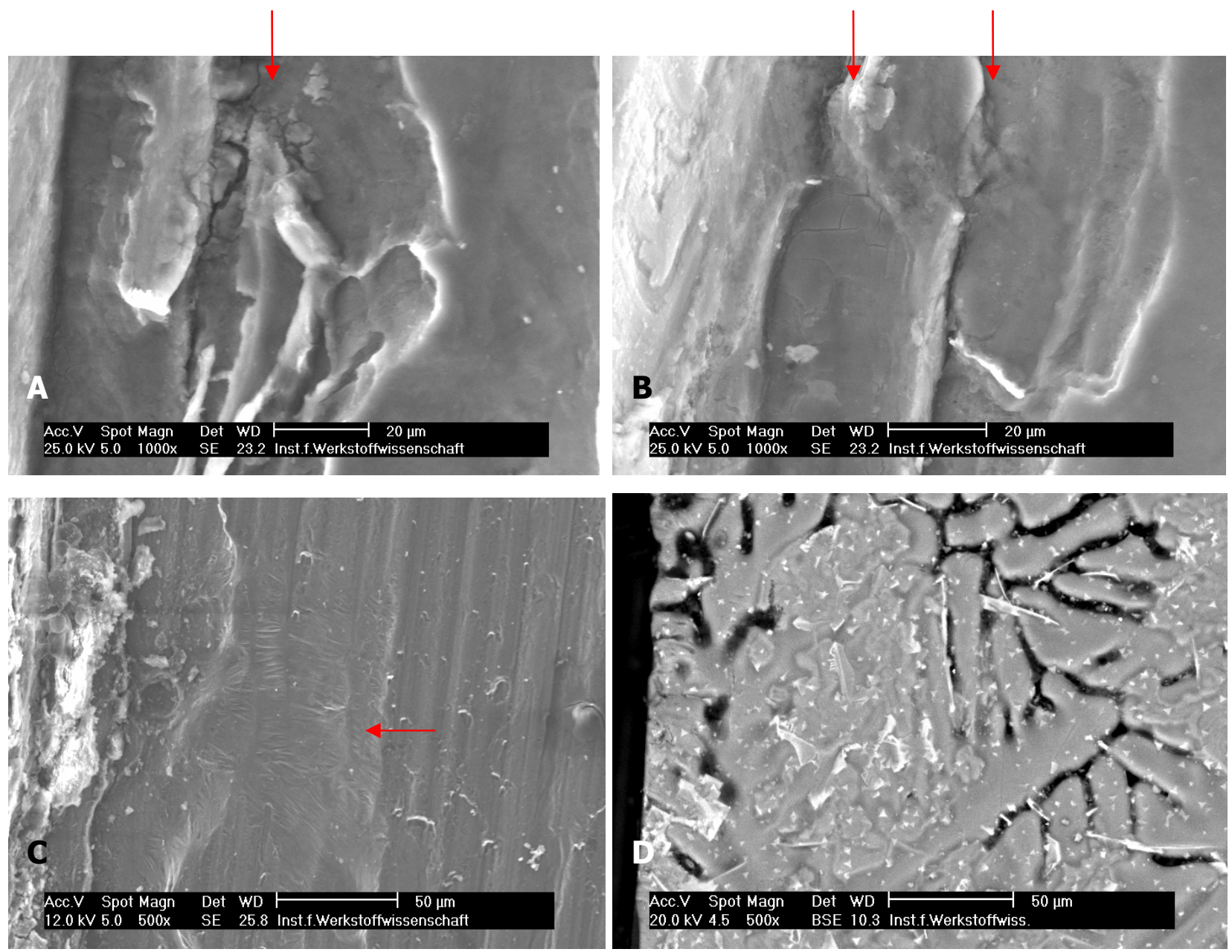

Figure 4.33 SEM micrographs showing the cracks in the casting at the edge positions of the insert (marked by arrows in A and B or reaction products; $\mathrm{C}$ ) shows vertically the replica of the turning marks of the steel insert (arrow), but in the middle there are some horizontal sliding marks and

(D) interdendritic porosity 
Looking at the plane through the middle of the thickness, we can see gaps between the insert and the casting parts in some places (see Figure $4.34-4.36$ ), but these do not open continuously. Figure 4.34 shows more or less bonded interface, which might have suffered some debonding during preparation. At the interface in positions

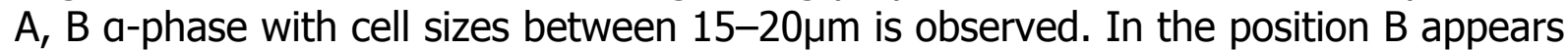
a continuous alpha layer, where there is no gap. The alpha cell sizes in position $\mathrm{C}$ are much smaller and drop to ca. $2 \mu \mathrm{m}$ in position $\mathrm{D}$.
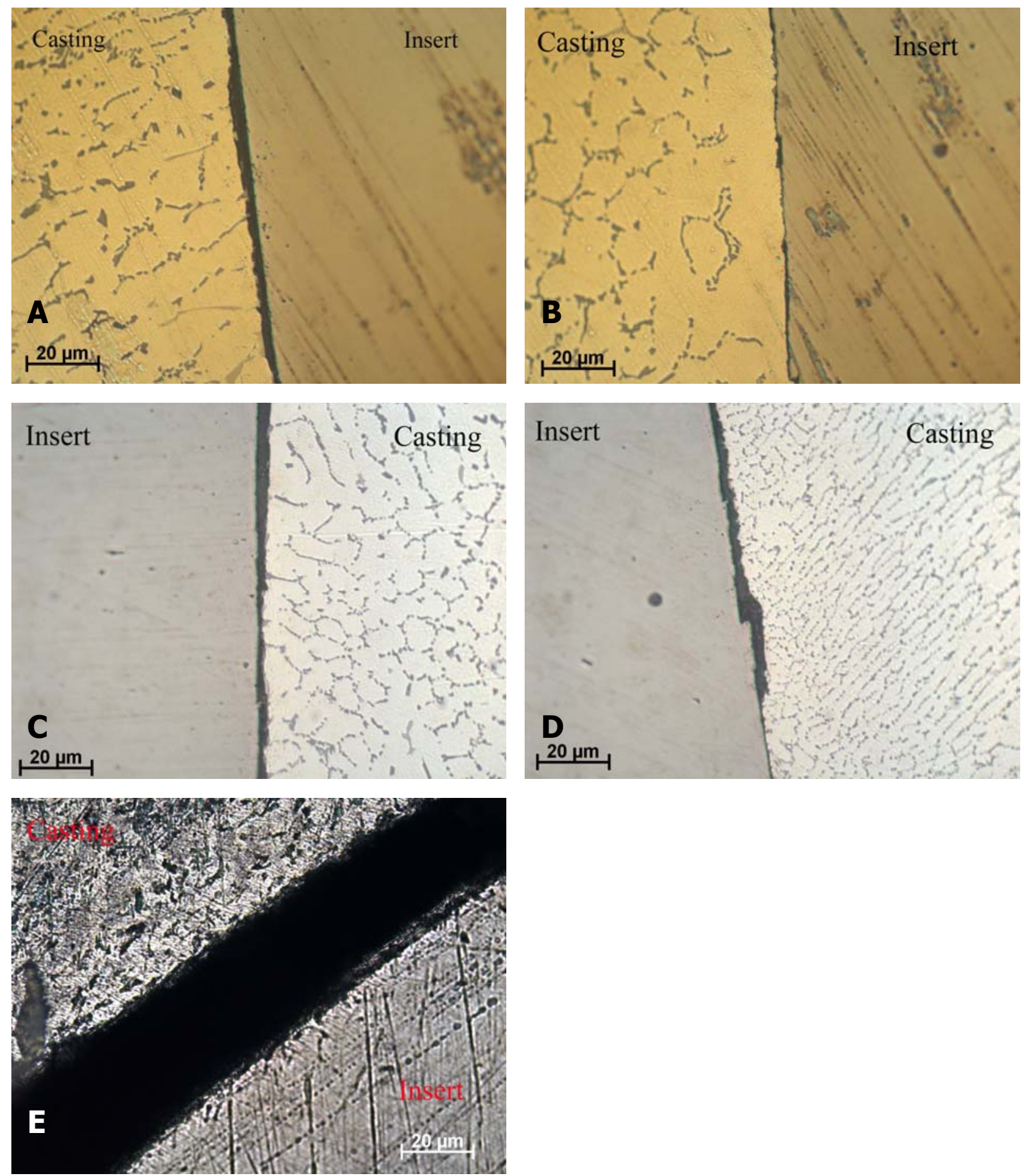

Figure 4.34 Microstructure of A, B) between the casting part and steel insert, C, D) gap between Al and steel (polished surface), E) gap between Al and steel (unpolished surface) 

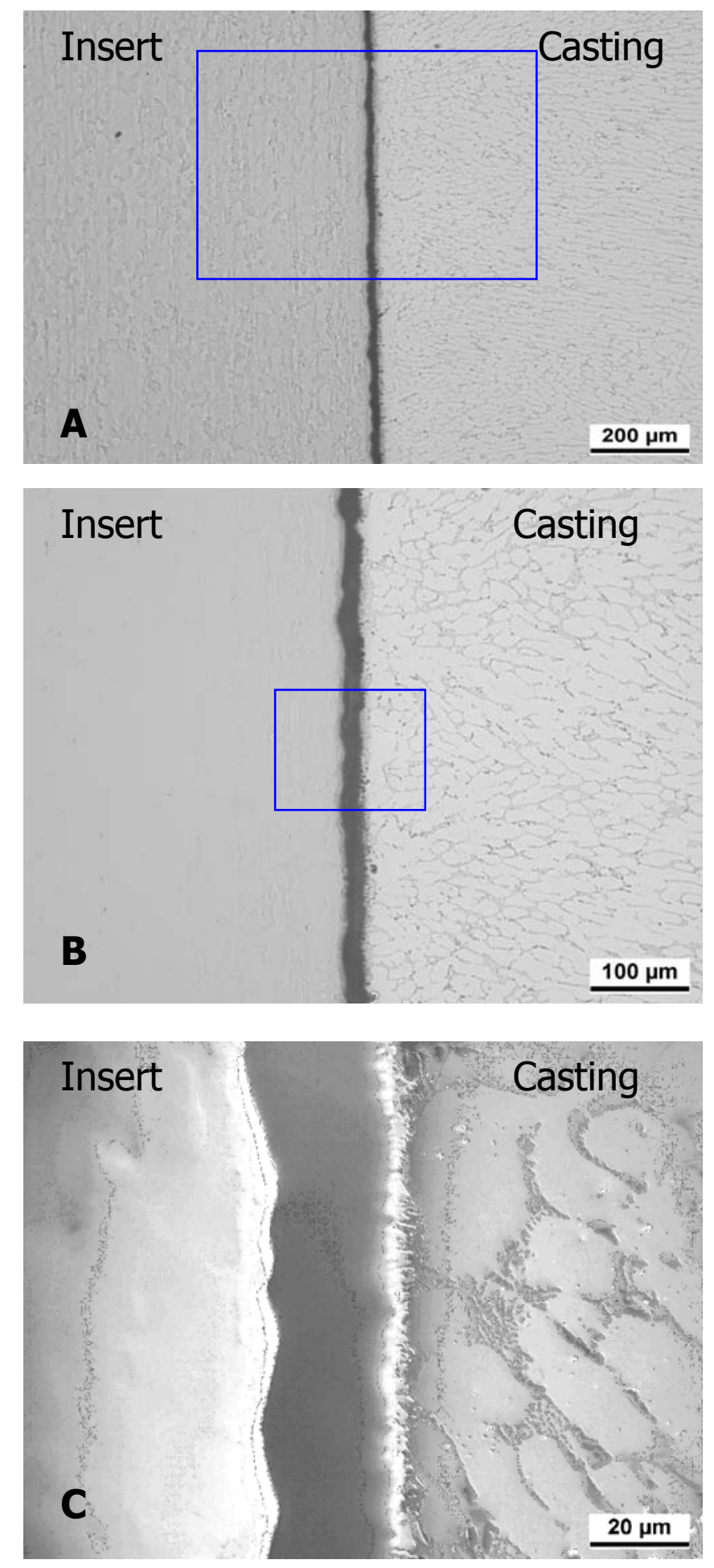

Figure 4.35 Different contrast of LOM of the cross section of the step sample along the axis direction of insert

Photomicrographs at different magnifications of the unetched surface are shown in Figure 4.35. No chemical bonding was recognized between the steel insert and the casting alloy. 
Figure $4.36 \mathrm{C}$, D shows clear gaps between aluminium and steel with some curvature in the Al casting with increased eutectic zones at the bonded interface section. The overviews in positions A-D show curved ends of the gaps. At the gaps dendrite cell diameters is of about $15 \mu \mathrm{m}$, somewhat smaller along the bonded sections, $<10 \mu \mathrm{m}$ in position $\mathrm{D}$. There is no cylindrical symmetry in the microstructure.
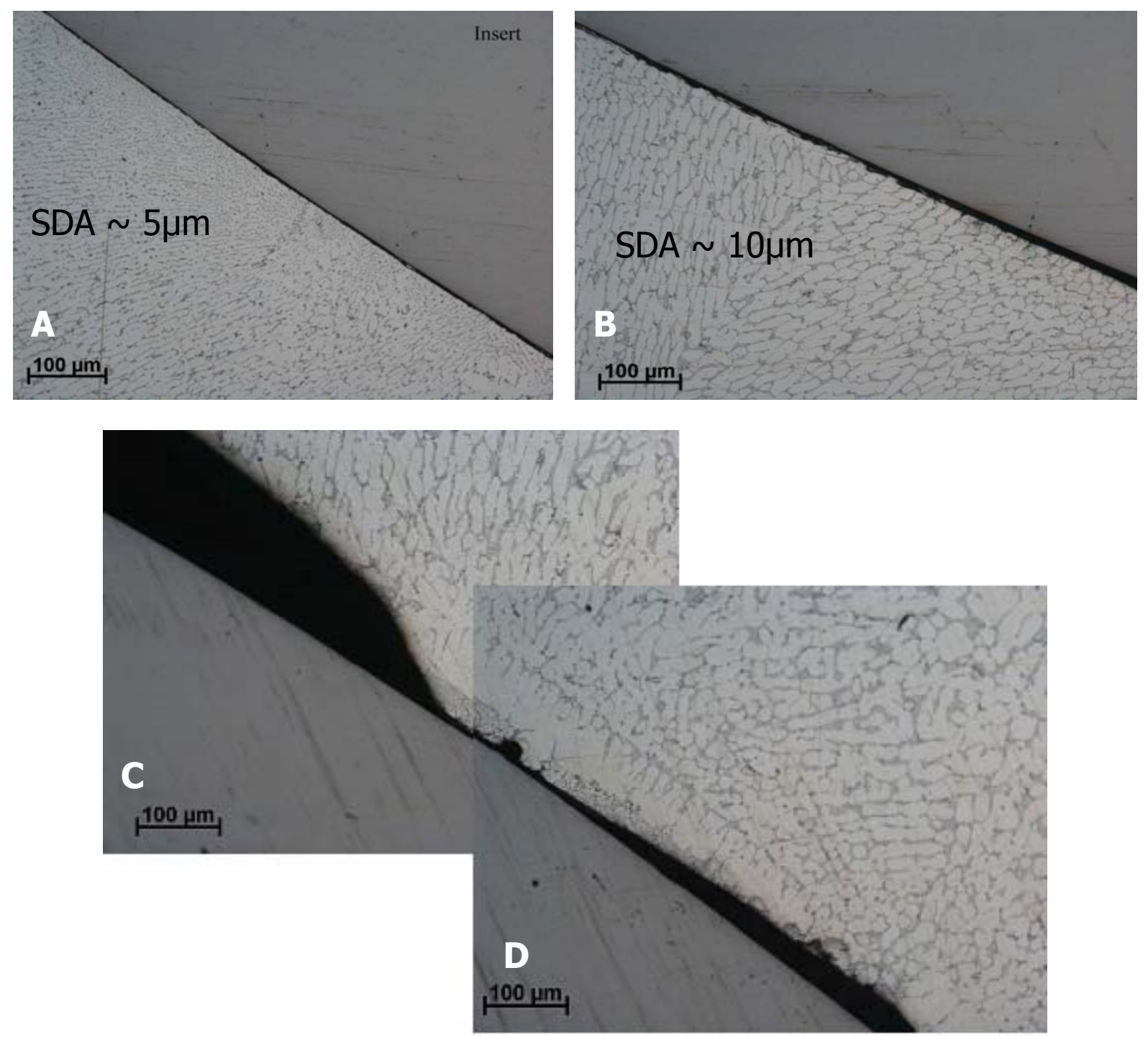

Figure 4.36 Optical micrographs of the step sample 7 of the cross section in the middle of the thickness with local gaps

Photomicrographs (Figure 4.37) show different microstructures of the casting next to the gap. We can see the changes of the structure, looking at the size of the dendrite arms. The structure of the bulk Al-casting is shown in the position $\mathrm{C}$ with dendrite

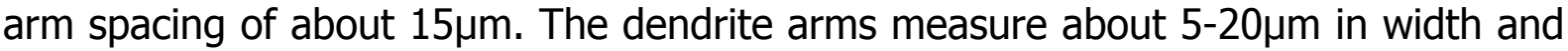
are mostly oriented in parallel, except between grains (E). Positions A, B, D-F show the borders of the Al casting towards the gap. There the direction of the solidification i.e. orientation of the dendrites can be concluded to be from the bulk to the gap. The interface to the gap consists mainly of Al-Si eutectic. So such gaps between steel insert and Al-casting were formed during solidification. 

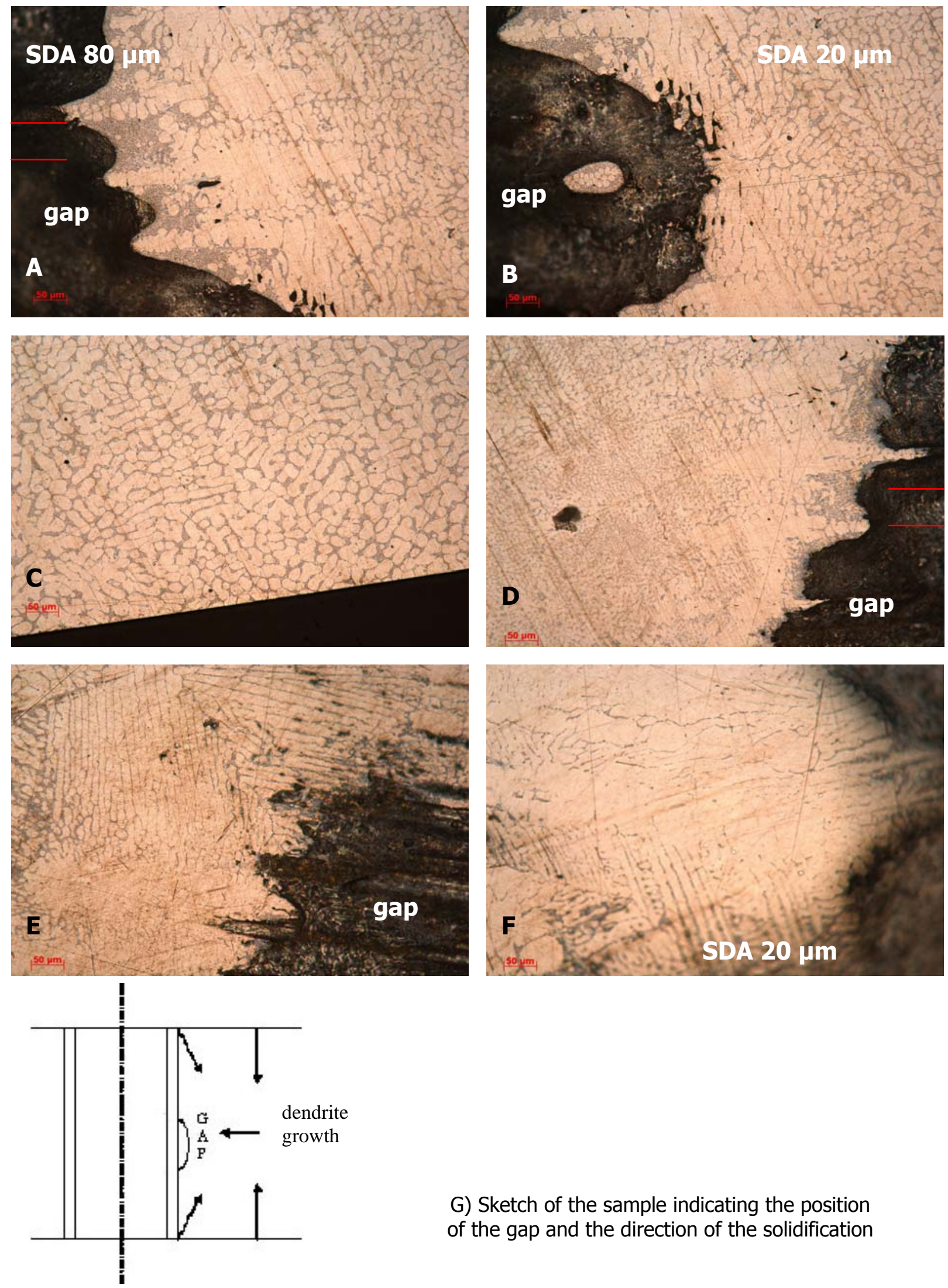

G) Sketch of the sample indicating the position of the gap and the direction of the solidification

Figure 4.37 Light optical microscopy along the thickness of the central third of the step sample 7 showing the microstructure of the Al-Si casting around the gap (all same magnifications) 
Table 4.38 Measured SDA of the investigated samples

\begin{tabular}{|c|c|c|c|c|c|c|c|c|c|}
\hline \multirow{2}{*}{$\begin{array}{c}\text { Figure } \\
\mathbf{N r}\end{array}$} & \multirow{2}{*}{$\begin{array}{c}\text { Sample } \\
\text { (section) }\end{array}$} & \multicolumn{8}{|c|}{ SDA [ $\mu \mathrm{m}]$} \\
\hline & & A & B & C & D & $\mathbf{E}$ & $\mathbf{F}$ & G & $\mathbf{H}$ \\
\hline \multicolumn{10}{|c|}{ Rods sample } \\
\hline 4.2 & I & 60 & 53 & 48 & 52 & & & & \\
\hline 4.3 & II & 52 & 58 & 26 & 75 & & & & \\
\hline 4.4 & III & 58 & 26 & 30 & 32 & & & & \\
\hline 4.5 & I & 63 & 73 & 66 & 73 & 97 & 63 & 66 & 63 \\
\hline 4.6 & II & 69 & 73 & 75 & 66 & 44 & & & \\
\hline 4.7 & III & 54 & 69 & 75 & 5 & & & & \\
\hline 4.8 & III & 52 & 32 & 42 & 45 & & & & \\
\hline 4.9 & II & 36 & 40 & 44 & 46 & & & & \\
\hline 4.10 & I & 37 & 39 & 36 & 40 & 44 & & & \\
\hline 4.11 & II & 56 & 34 & 68 & & & & & \\
\hline 4.12 & III & 29 & 31 & 30 & 34 & & & & \\
\hline \multicolumn{10}{|c|}{ Cube sample } \\
\hline & & & & & & & & & \\
\hline 4.13 & & 60 & 100 & 200 & 300 & & & & \\
\hline \multirow{2}{*}{\multicolumn{10}{|c|}{ Step sample }} \\
\hline & & & & & & & & & \\
\hline 4.14 & I & 4 & 6 & 5 & 5 & 4 & 13 & 8 & 15 \\
\hline 4.15 & II & 20 & 20 & 3 & 10 & $<3$ & 10 & & \\
\hline 4.18 & III & 13 & 13 & 10 & 19 & 20 & & & \\
\hline 4.19 & IV & 3 & 7 & 8 & 10 & & & & \\
\hline 4.36 & gap & 5 & 10 & 15 & 15 & & & & \\
\hline 4.37 & gap & 100 & 20 & 15 & & 10 & 20 & & \\
\hline & & & & & & & & & \\
\hline \multicolumn{10}{|c|}{ Demo-axial sample } \\
\hline & & & & & & & & & \\
\hline 4.21 & & 30 & 24 & 10 & & & & & \\
\hline 4.22 & & 47 & 32 & 44 & 38 & & & & \\
\hline 4.23 & & $30-52$ & 43 & 36 & $27-33$ & 30 & & & \\
\hline & & & & & & & & & \\
\hline
\end{tabular}


Figure 4.39 shows the intermetallic phases of the rod sample 5 . The width of the islands is changing from about $20 \mu \mathrm{m}(\mathrm{A})$ to about $115 \mu \mathrm{m}$ in position $\mathrm{C}$. The phases are mostly observed on the steel insert side. We found as well lots of porosity and cracks in the casting part of the sample.
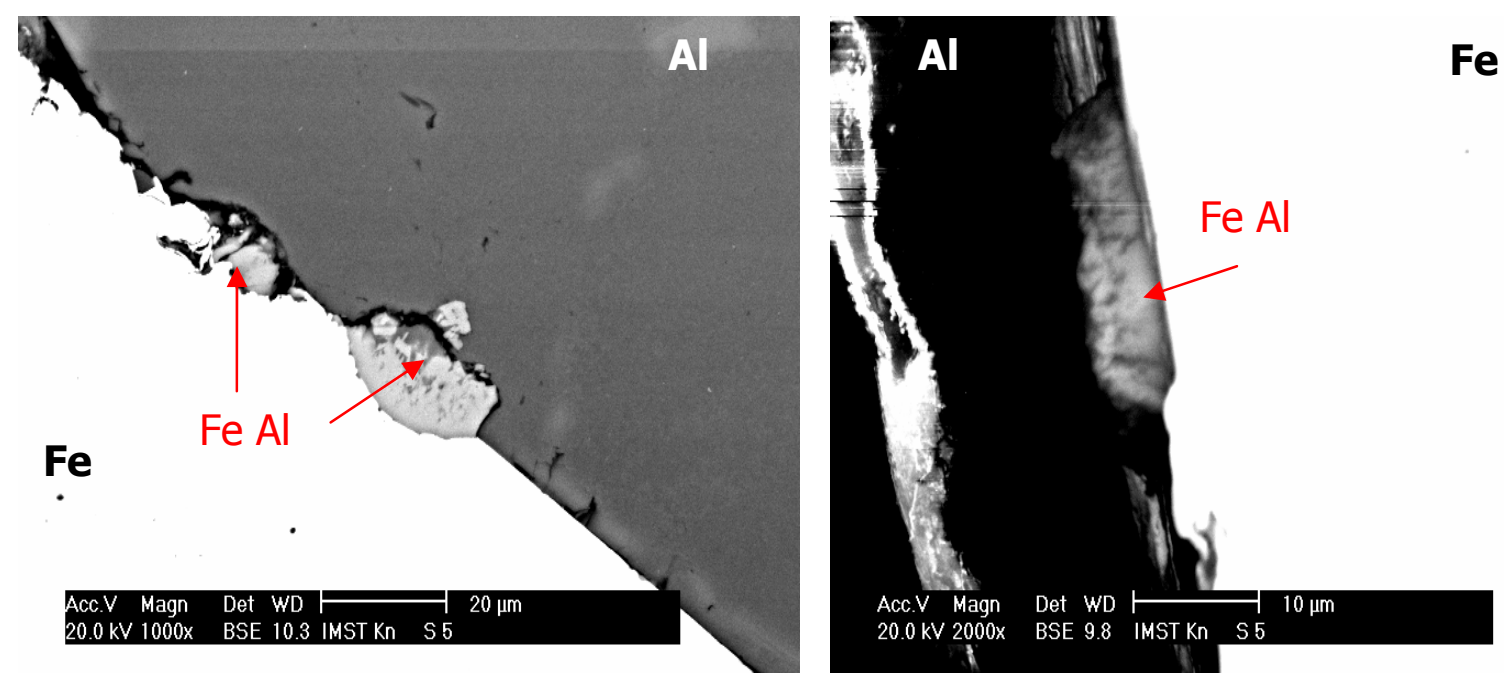

A

B

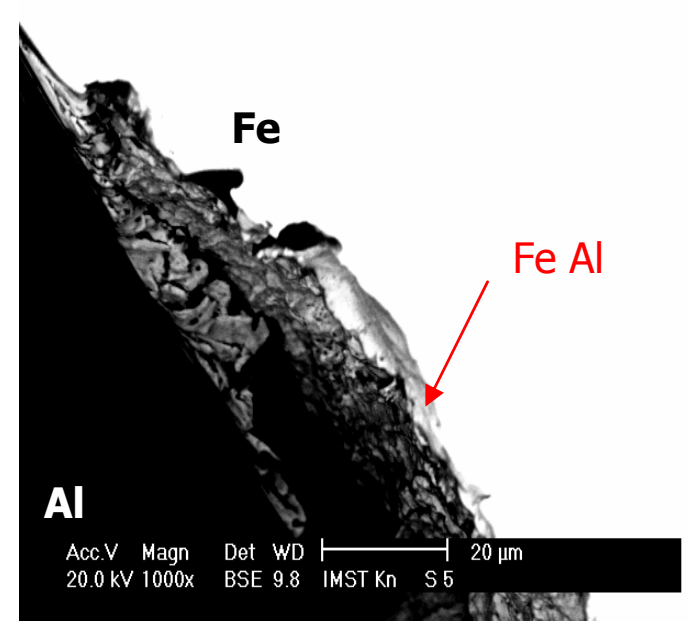

C

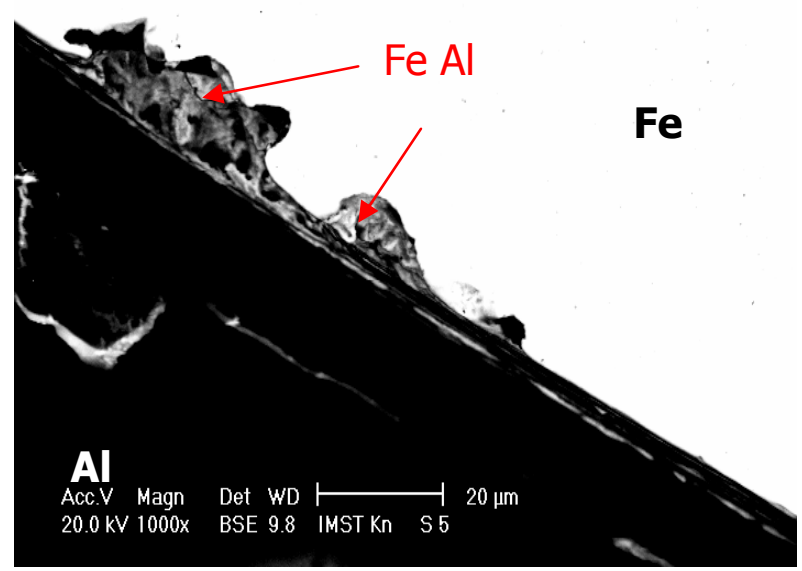

D

Figure 4.39 SEM micrographs showing intermetallic islands on the cross section of the rod sample 5 
Intermetallic islands of sample 7 we can observe in Figure 4.40. Different intermetallic phases are changing size from about $5 \mu \mathrm{m}$ at the position $\mathrm{D}$ to about $60 \mu \mathrm{m}$ (C). On this sample islands appear only on the steel side and mostly in rounded shape. Although the insert of sample 5 (Figure 4.39) had been etched, there are only a few islands of Fe-aluminides. The stainless steel insert of sample 7 shows similar interface characteristic. It seems that solidification started from the steel insert, but produced only little interface reaction, see Figure 4.40. Interface bonding was good enough to cut the samples without disintegration.

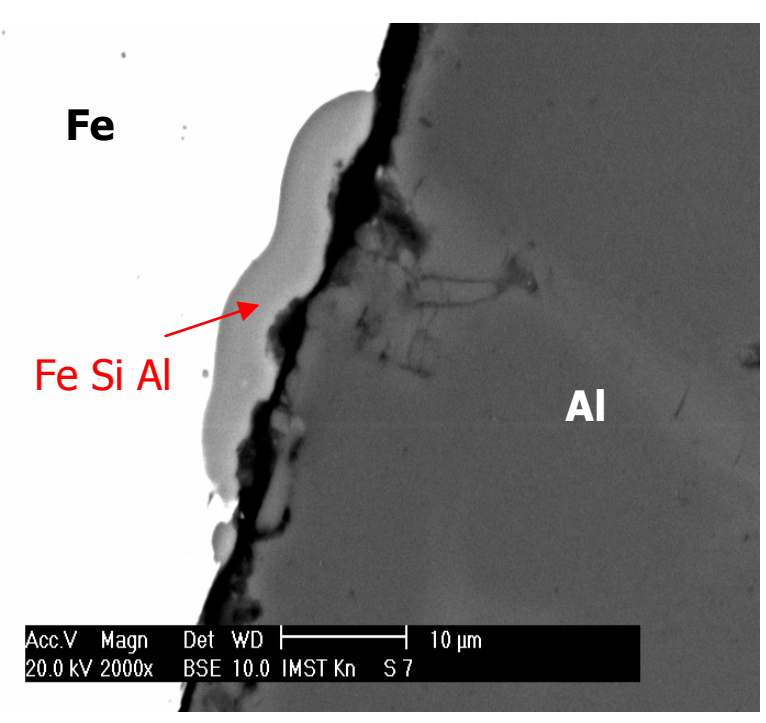

A

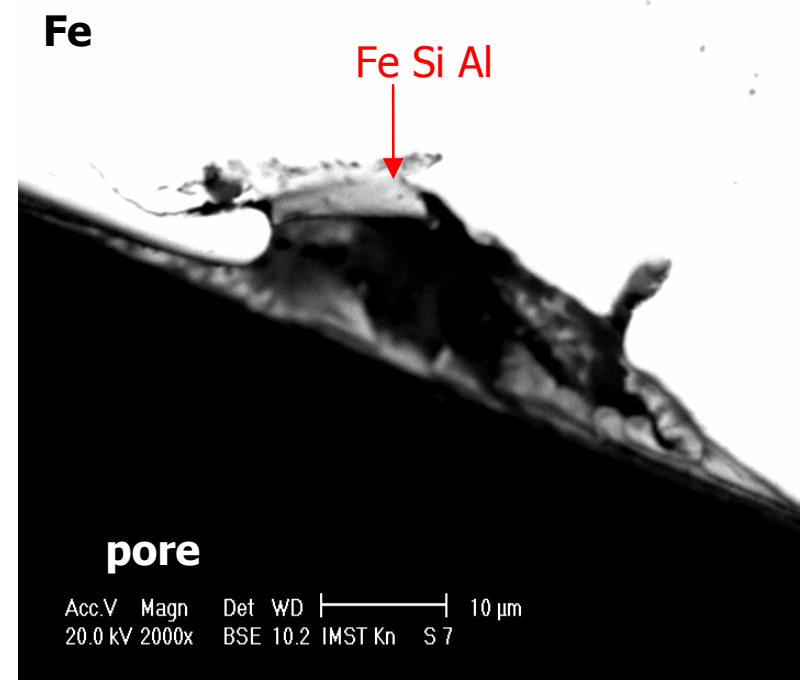

C

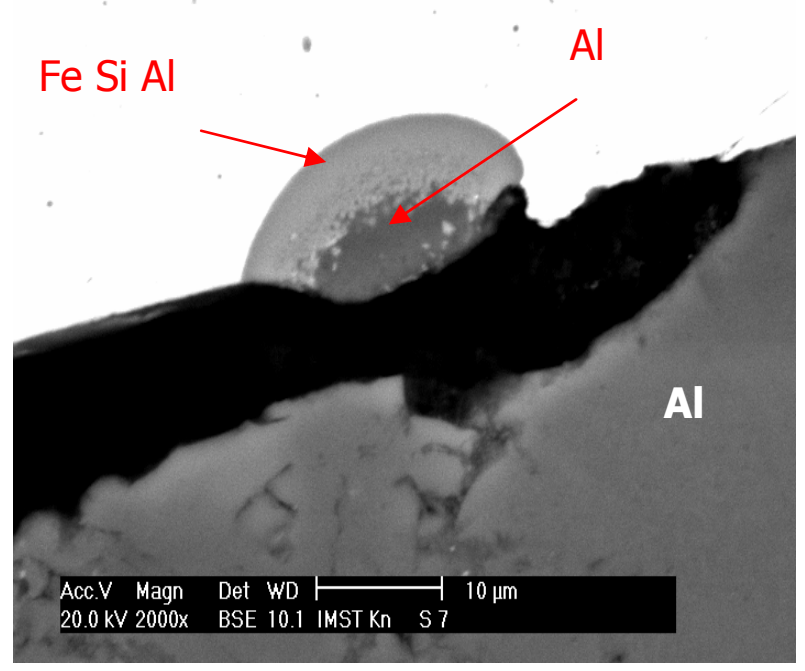

B

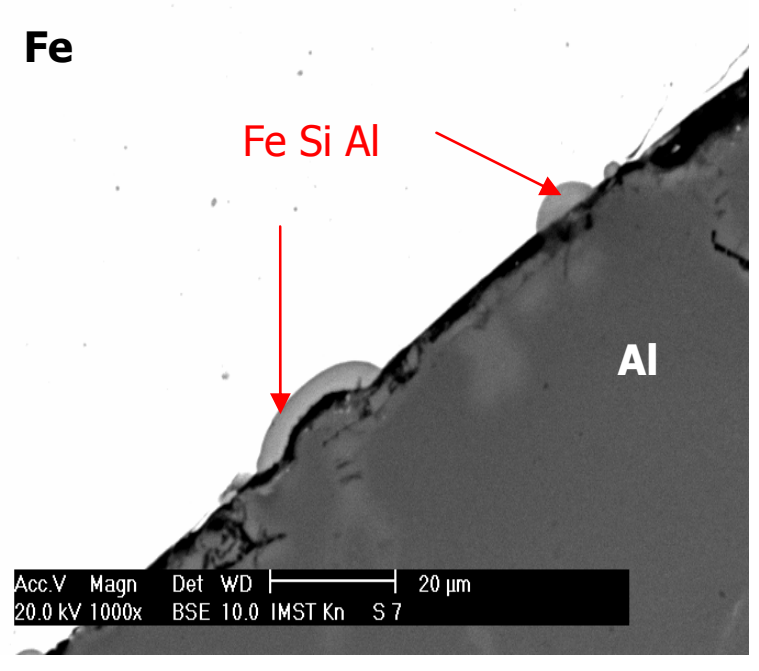

D

Figure 4.40 SEM micrographs showing intermetallic phases of the rod sample 7 
Different kinds of intermetallic phases can be observed in Figure 4.41 (sample 2) formed by pure Al at the cube insert when solidification process from the RT mould. Interface reactions are along the whole interface. In the aluminium and steel side cracks are observed. SEM micrographs show the cracks marked by blue arrows. On

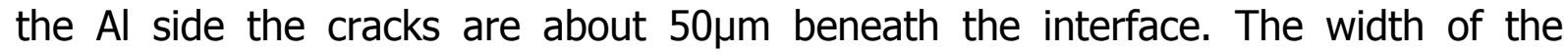
phases is from about $10 \mu \mathrm{m}(\mathrm{A})$ to about $13 \mu \mathrm{m}$ in (C).
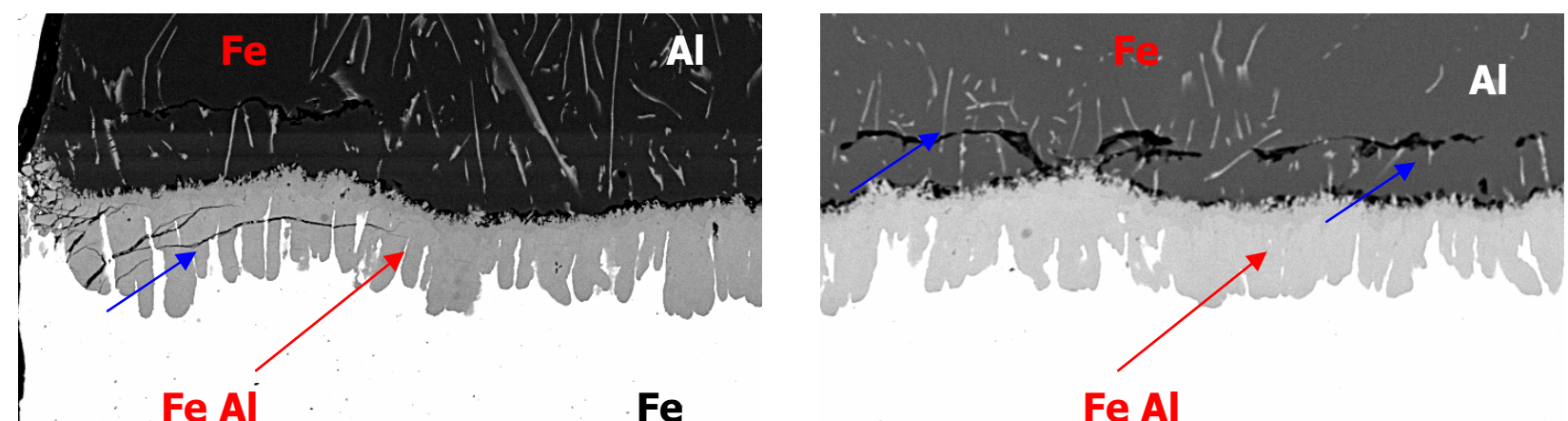

Fe Al

Fe
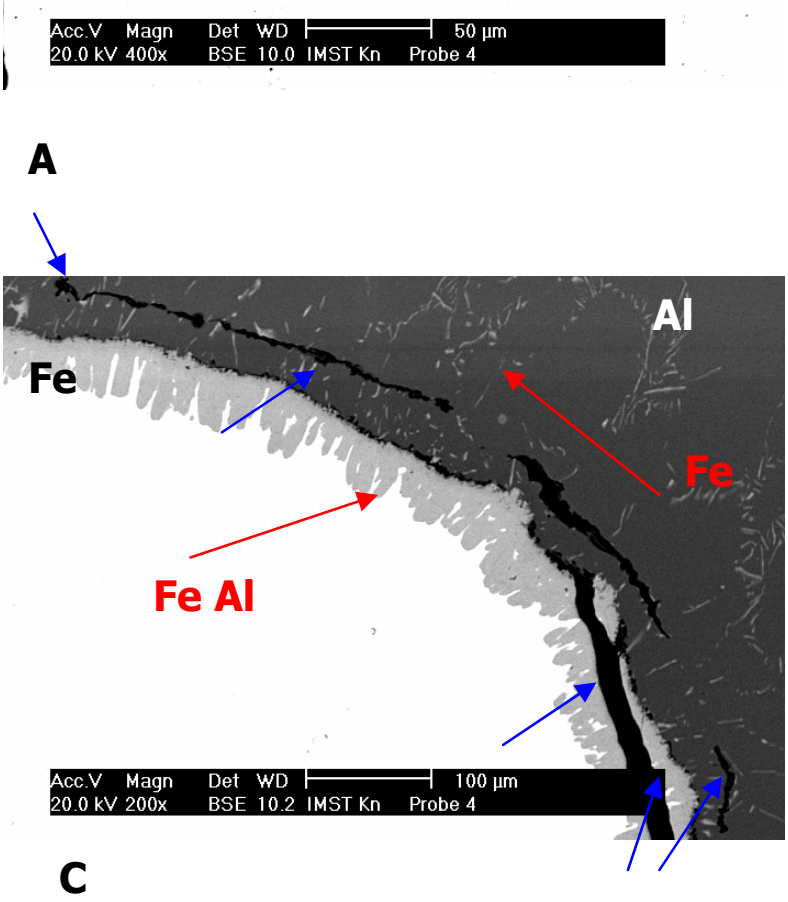

B
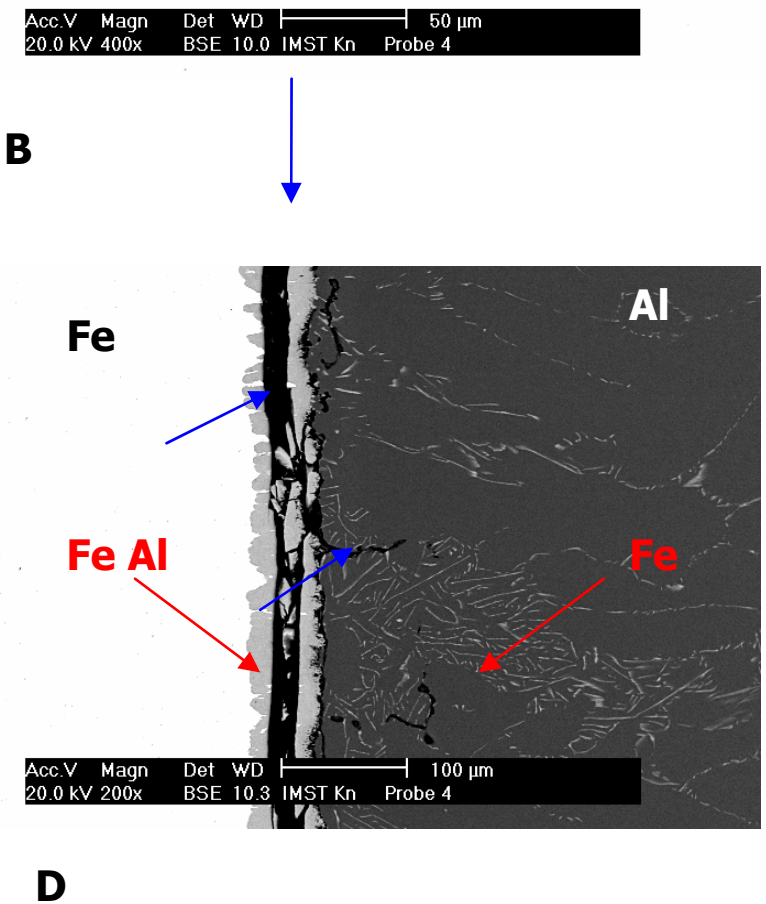

Figure 4.41 Shows the intermetallic phases of the cube sample 2 (mould at RT) 
SEM micrographs (Figure 4.42) showing the interface reactions of the sample 1 (Al at the $700^{\circ} \mathrm{C}$ ). Figure $\mathrm{C}$, D show clear cracks between Al and steel in the cast sample and on the steel side. The size of the intermetallic phases is changing from about $15 \mu \mathrm{m}$ at (C) to $19 \mu \mathrm{m}$ (D) in width. Small porosity is observed (C).

Figure 4.43 shows reaction islands on both sides on the cross section of the sample 3 (AlSi7 at the $700^{\circ} \mathrm{C}$ ). The pores are considerably bigger than in sample 1 and 2 . The width of the interface reaction are changing from about $80 \mu \mathrm{m}(\mathrm{E})$ to about $300 \mu \mathrm{m}$ at the micrograph (F).
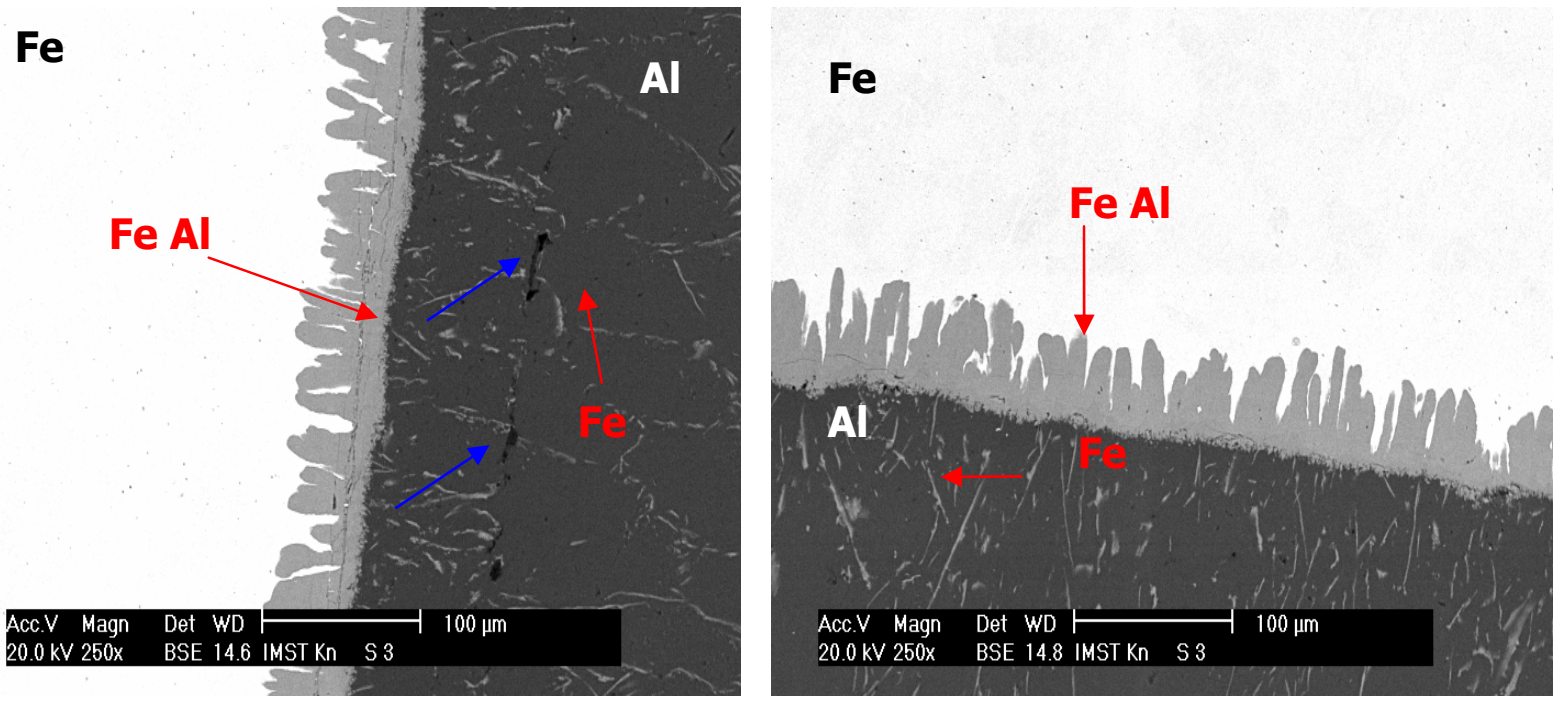

A

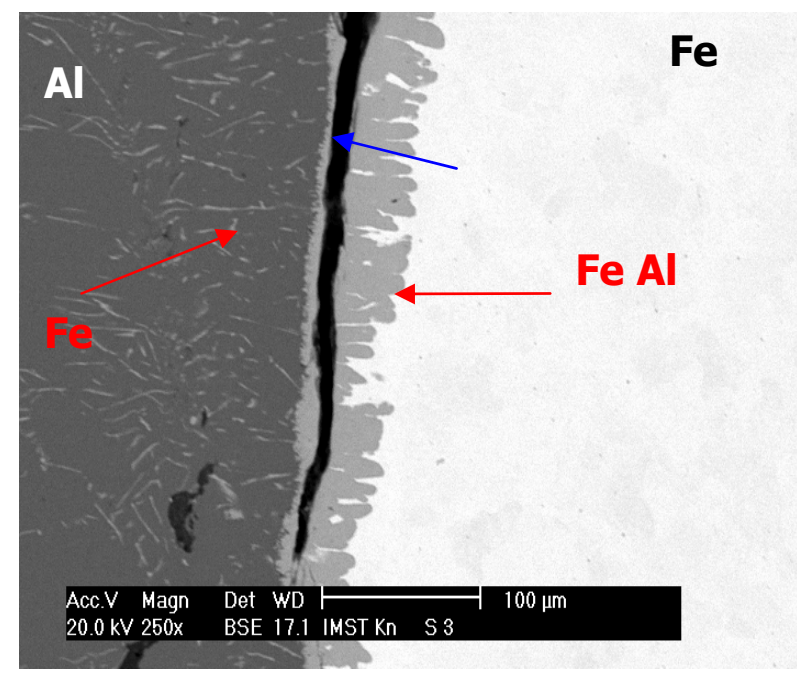

C
B

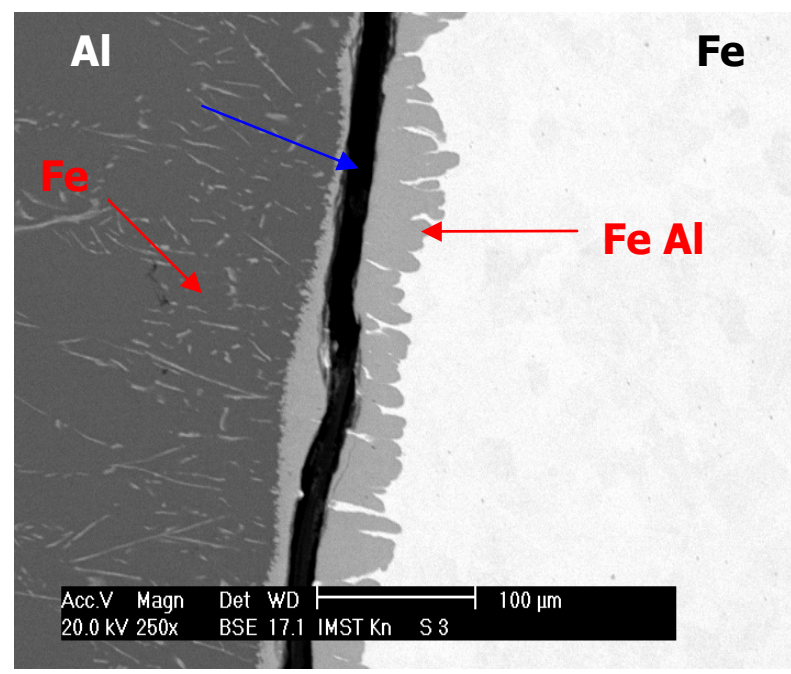

D

Figure 4.42 Intermetallic phases of the cube sample 1 (Al cast, mould at the $700^{\circ} \mathrm{C}$ ) 


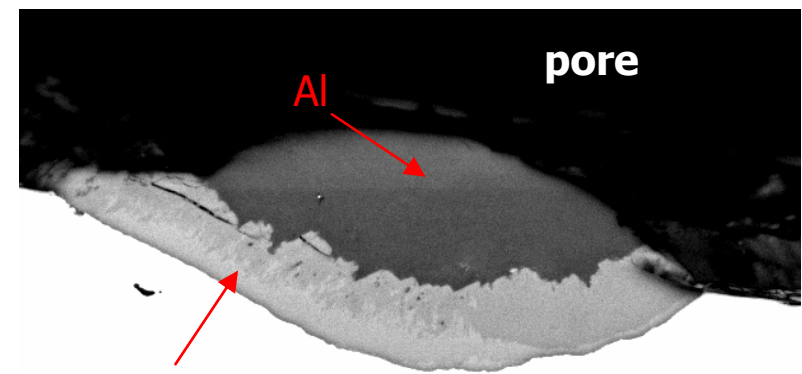

Al Si Fe

Fe

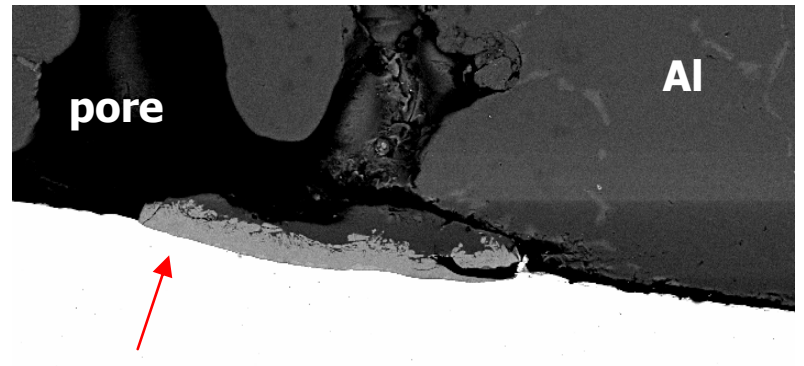

Al Si Fe

Fe

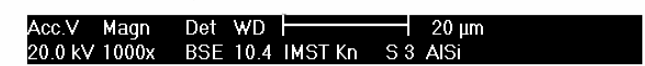

A

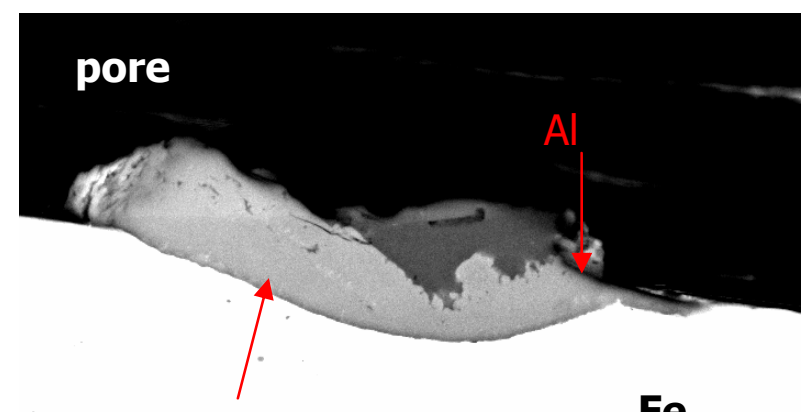

Al Si Fe

Fe

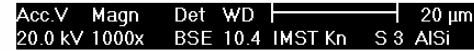

C

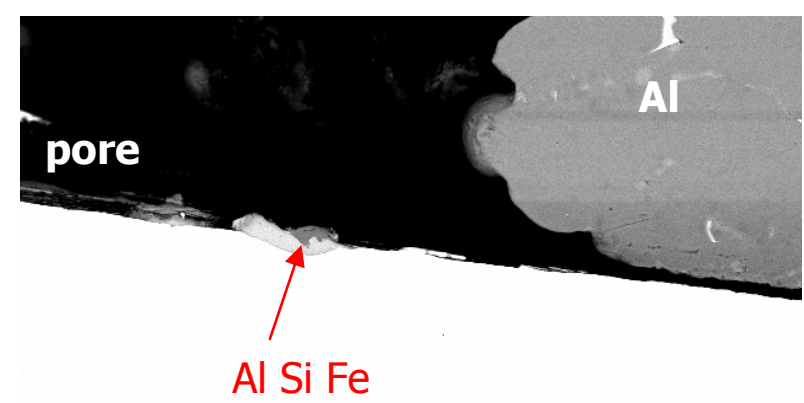

Fe

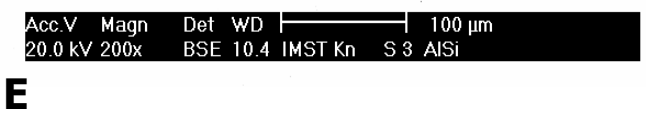

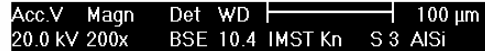

B
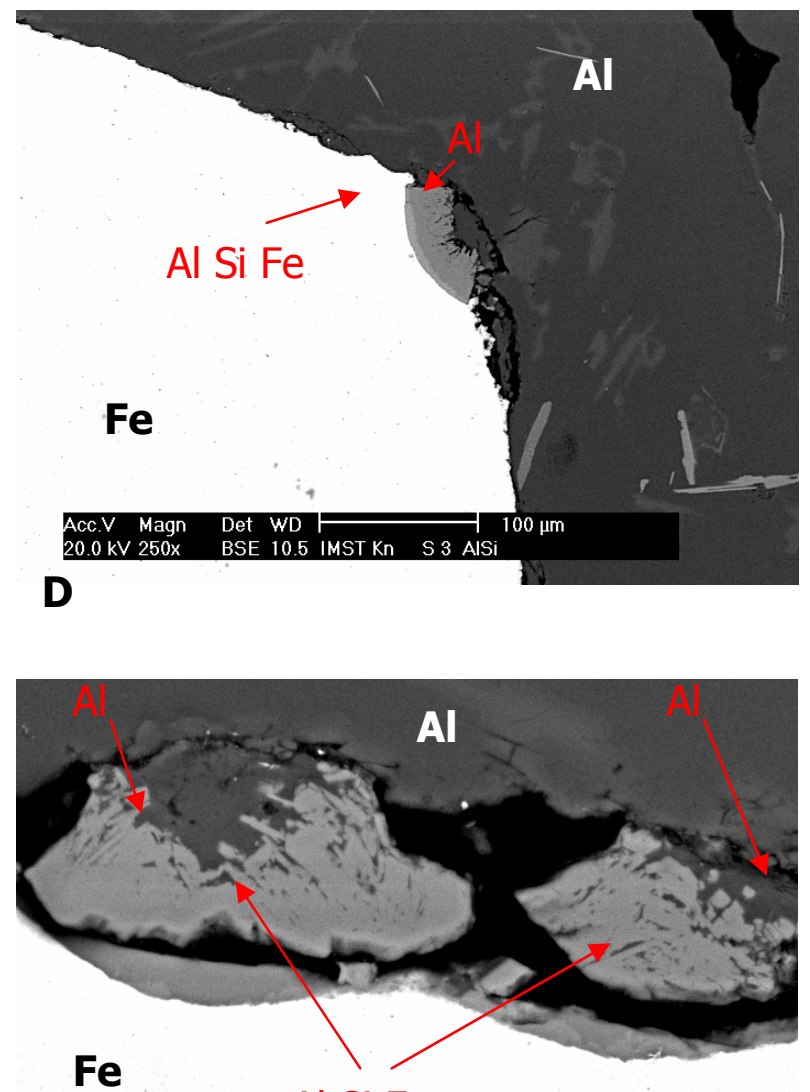

Al Si Fe

Figure 4.43 SEM micrographs showing intermetallic reactions of the cube sample 3 (AlSi7 cast, mould at the $700^{\circ} \mathrm{C}$ ) 


\subsubsection{Shrinkage holes around cube insert}

View of the $5 \mathrm{~mm}$ thick slices of the cube sample 3 and 4 show Figure 4.44. We can observe, that the steel didn't stick to the aluminium along the whole interface $(A, B)$, but cracks had been formed in the Al-casting starting from the corners of the insert.

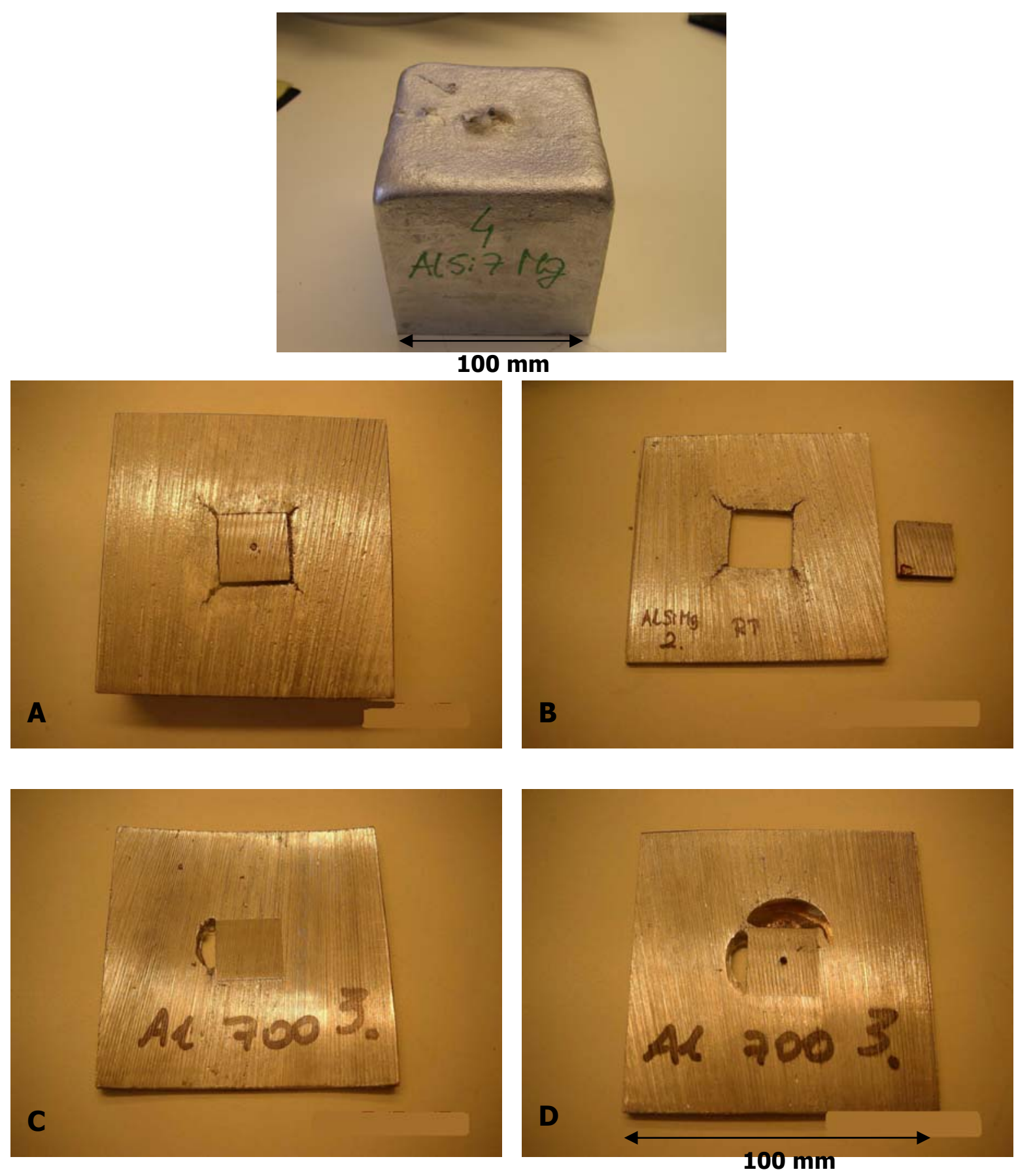

Figure 4.44 View of the cube samples where the cracks in A and B (sample 4) as well as the pores in $\mathrm{C}$ and $\mathrm{D}$ (sample 1) were observed 


\subsection{Hardness of castings}

Figure 4.45 shows the results of the Brinell hardness in the AlSi7Mg0.3 alloy after different thermal conditions. The lowest value is observed after a heat treatment of $350^{\circ} \mathrm{C}$ for $2 \mathrm{~h}$. The highest value of $106 \mathrm{HB}$ shows the sample after heating to $165^{\circ} \mathrm{C}$ for $15 \mathrm{~h}$. Hardness of as cast condition increases very slightly after aging at $165^{\circ} \mathrm{C}$ for 2.5h.

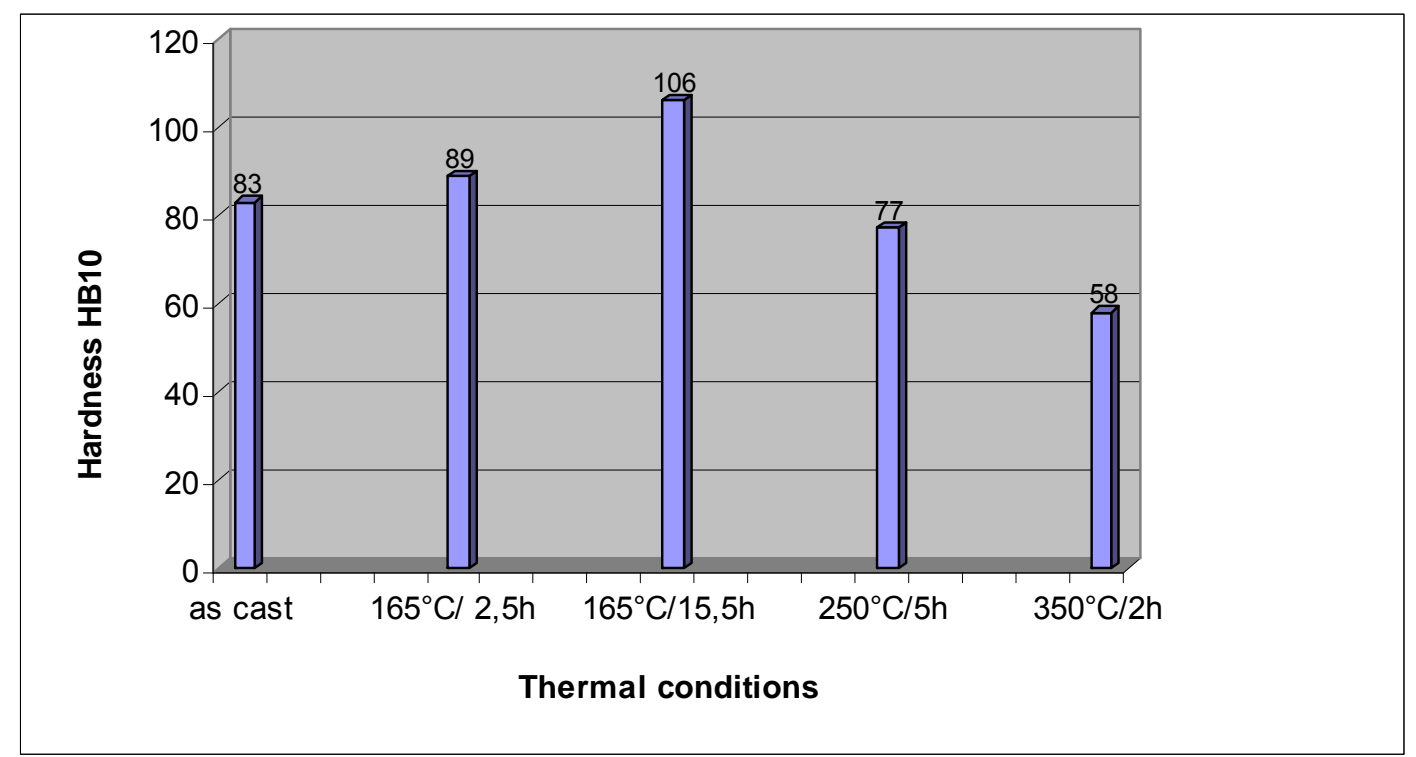

Figure 4.45 Brinell hardness results of Demo-axial sample (AISi7Mg0.3) after different thermal conditions

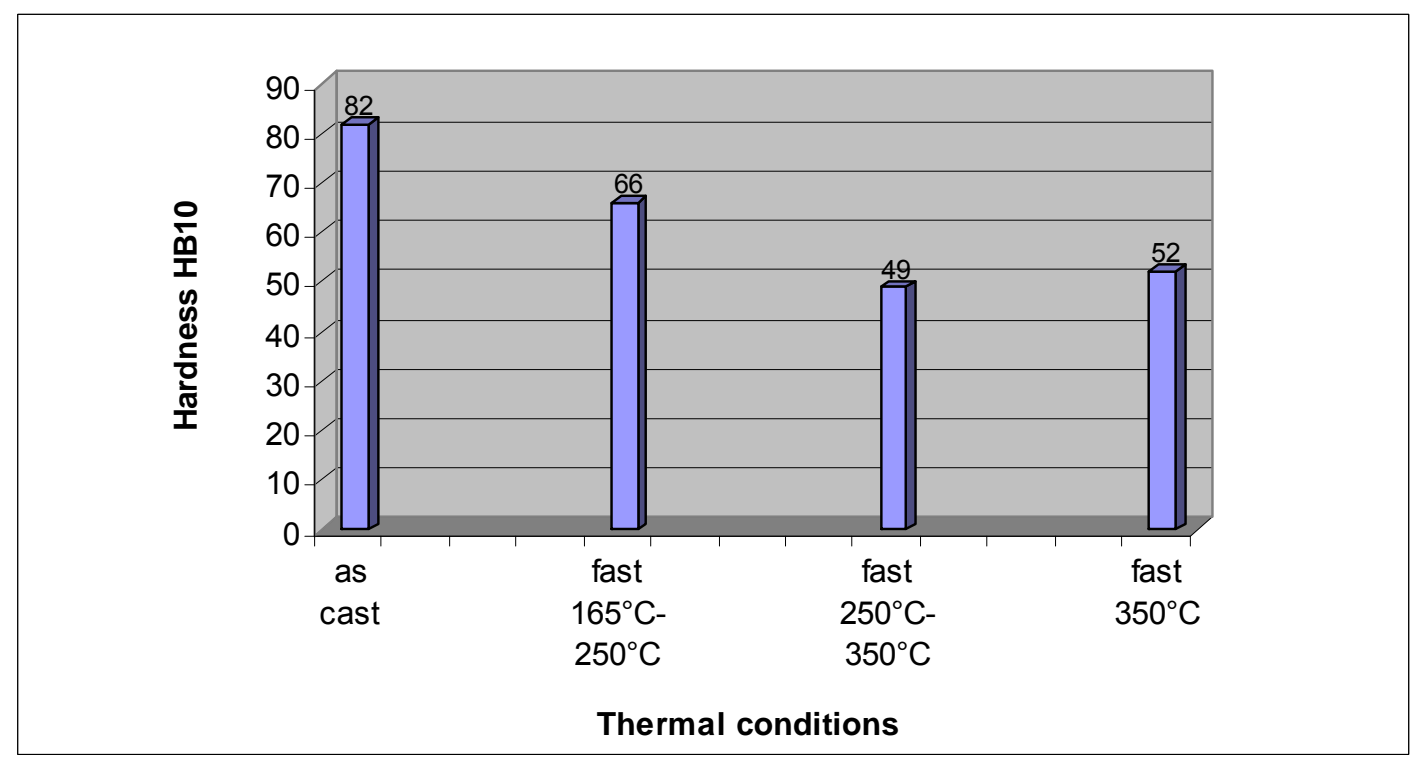

Figure 4.46 Hardness test results for different thermal conditions for the AlSi7Mg0.3 air cooled after Bähr dilatometry with heating rate of $50 \mathrm{~K} / \mathrm{s}$ 
The hardness of AlSi7Mg0.3 as cast and after different thermal conditions using Bähr dilatometry is presented in Figure 4.46. The hardness decreases slowly after heating from $165^{\circ} \mathrm{C}$ to $250^{\circ} \mathrm{C}$ with the heating rate of $50 \mathrm{~K} / \mathrm{s}$ and is significantly lower after heating from as cast condition to $350^{\circ} \mathrm{C}$.

Figure 4.47 depicts the Brinell value of AlSi7Mg0.3 alloy for as cast condition, after heat treatment at $165^{\circ} \mathrm{C}$ for $2.5 \mathrm{~h}$ after TMA with heating rate of $5 \mathrm{~K} / \mathrm{min}$ and with cooling rate of $10 \mathrm{~K} / \mathrm{min}$. TMA- solution treatment decreases the hardness from 87 to $56 \mathrm{HB}$.

Using differential scanning calorimetry decreases the hardness value from $81 \mathrm{HB}$ in the $165^{\circ} \mathrm{C} / 10 \mathrm{~h}$ condition to $88 \mathrm{HB}\left(7 \%\right.$ lower) after heating to $540^{\circ} \mathrm{C}$ with heating rate of $10 \mathrm{~K} / \mathrm{min}$ and with cooling rate of $20 \mathrm{~K} / \mathrm{min}$ (see Figure 4.48). Similar situation we can observe for the sample heated to $250^{\circ} \mathrm{C}$ for $5 \mathrm{~h}$ with hardness value of 67 , thereafter hardness decreases to $52 \mathrm{HB}$.

Bähr dilatometry with heating rate of $50 \mathrm{~K} / \mathrm{s}$ and cooling rate of $20 \mathrm{~K} / \mathrm{min}$ changes the hardness value of the step sample (Figure 4.49).

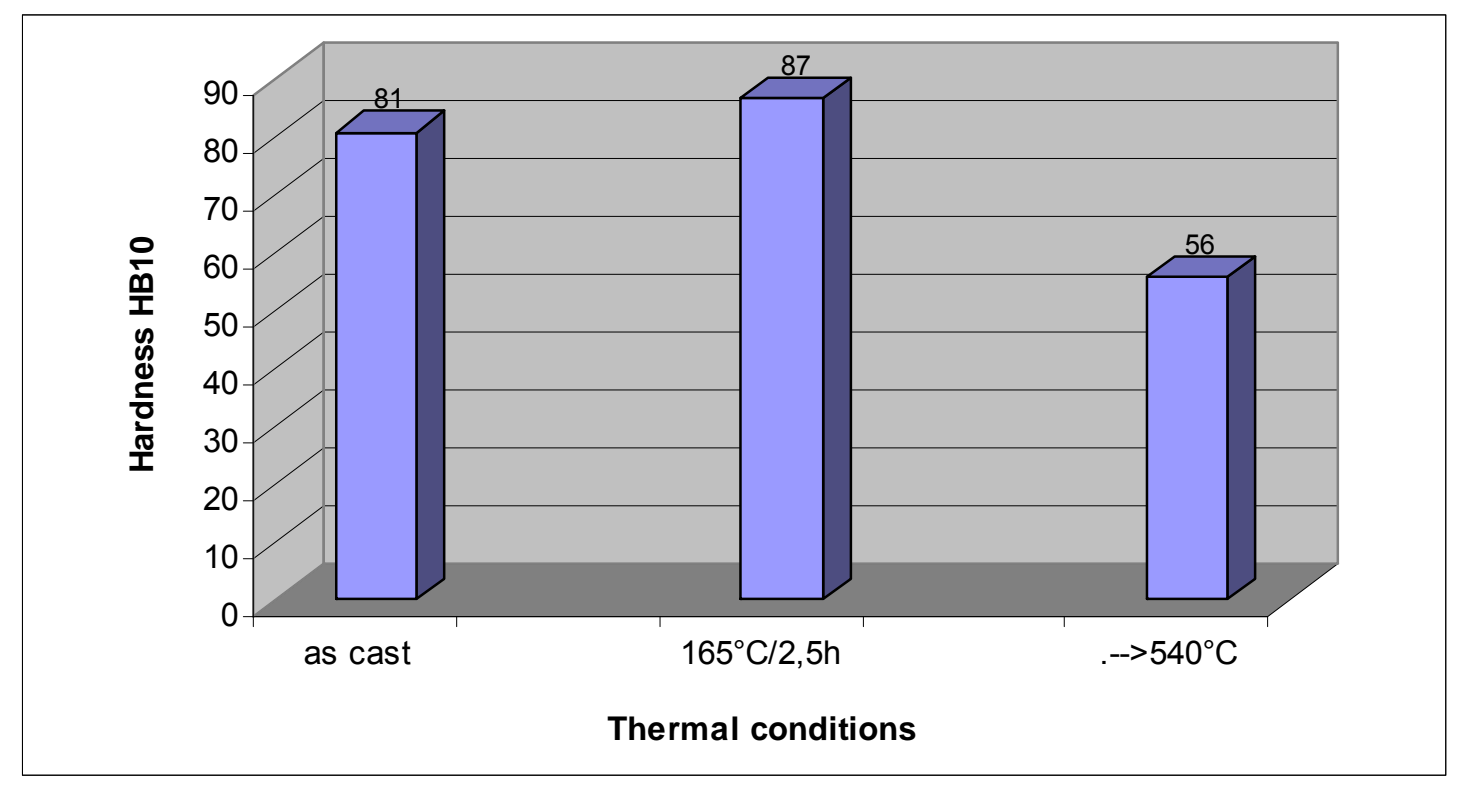

Figure 4.47 Brinell hardness results of investigated demo-axial sample after TMA treatments at the indicated $T$ with heating rate of $5 \mathrm{~K} / \mathrm{min}$ and cooling rate of $10 \mathrm{~K} / \mathrm{min}$ 


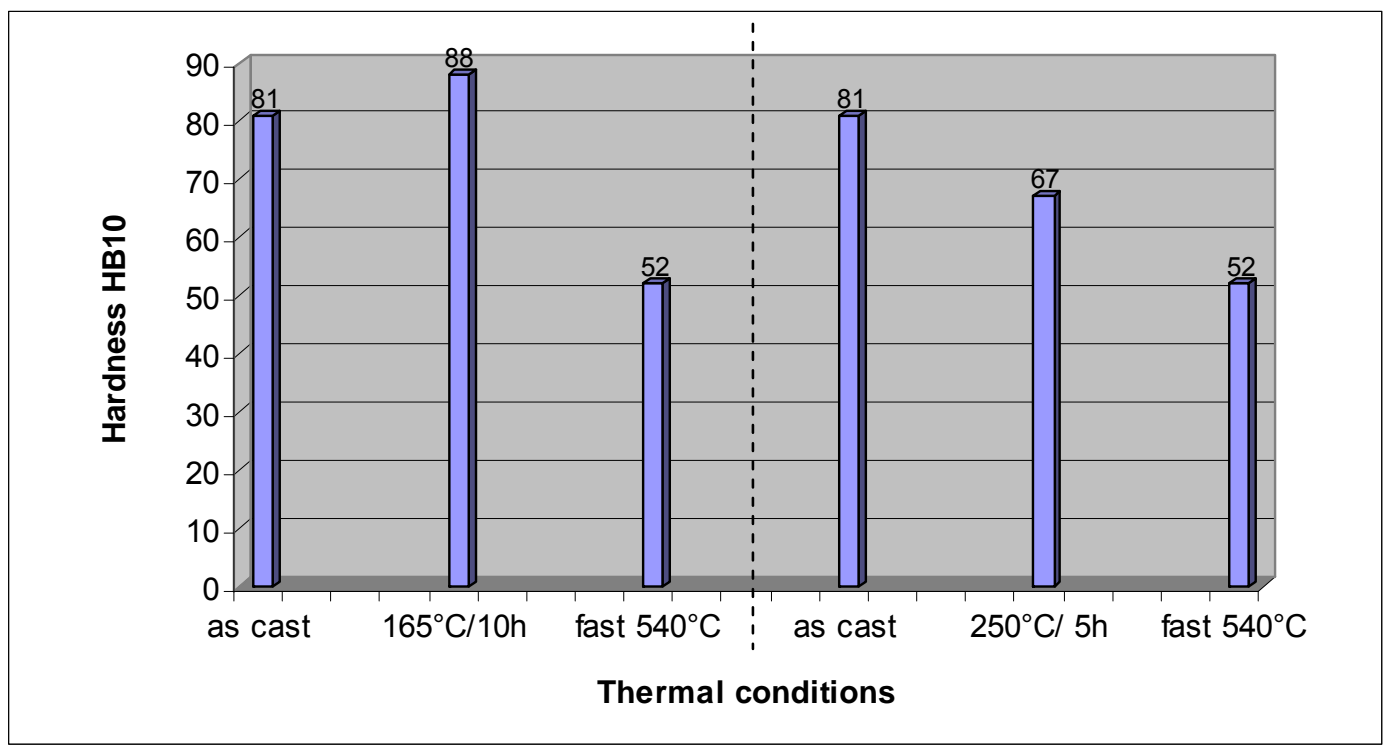

Figure 4.48 Hardness test results of two samples from the step sample (AISi7Mg0.3) after DSC treatments at the given temperatures with heating rate of $10 \mathrm{~K} / \mathrm{min}$, cooled $20 \mathrm{~K} / \mathrm{min}$

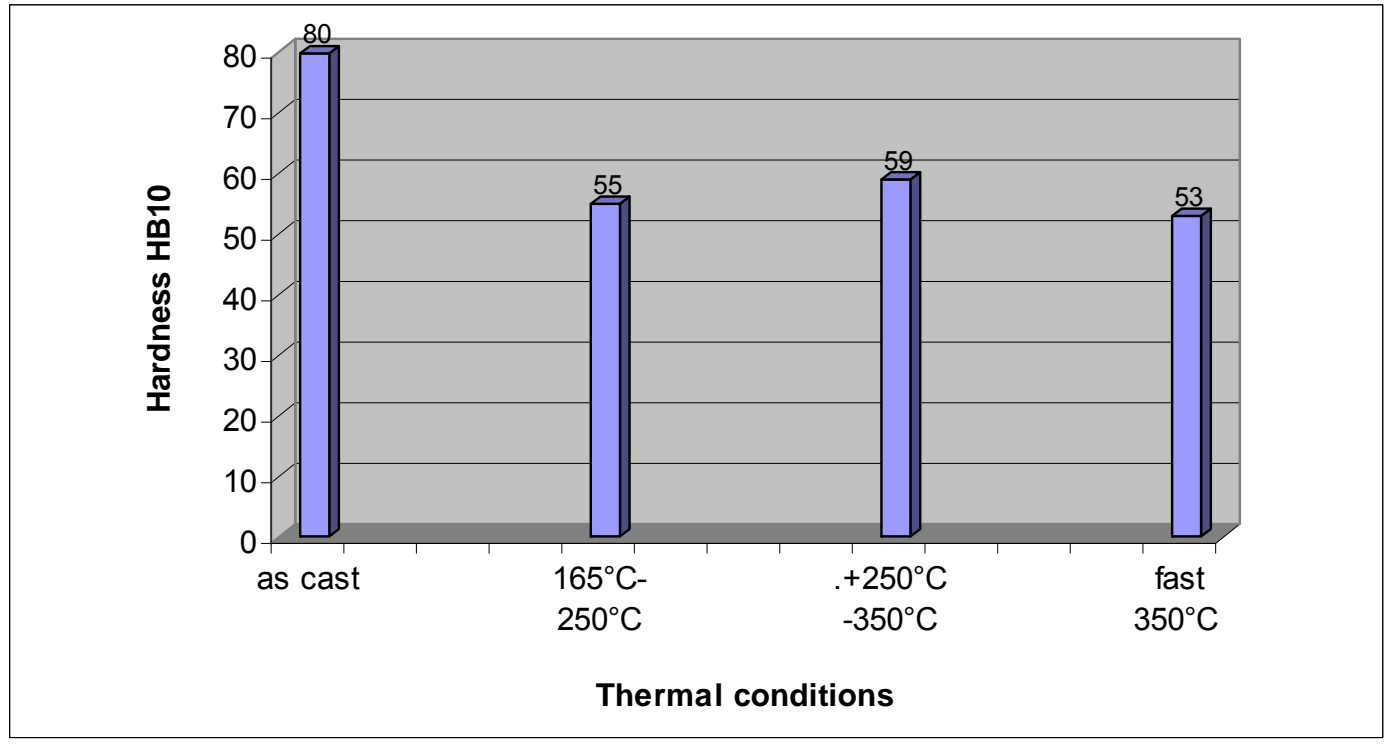

Figure 4.49 Hardness results of step sample (AlSi7Mg0.3) after Bähr dilatometry with heating rate of $50 \mathrm{~K} / \mathrm{s}$, cooled with $20 \mathrm{~K} / \mathrm{min}$

Figure 4.50 shows micro-hardness measurements of the as cast demo-axial sample at different location on the sample. We measured the hardness value on the sample with the dendrite arm spacing of $12 \mu \mathrm{m}, 4 \mu \mathrm{m}$ and on the eutectic. We can see very high differences of hardness between eutectic and arm spacing of $12 \mu \mathrm{m}$. Looking on the Figure 4.51 we can observe that the hardness value of the eutectic is much higher than on the position with SDA of $50 \mu \mathrm{m}$ and17 $\mu \mathrm{m}$. 


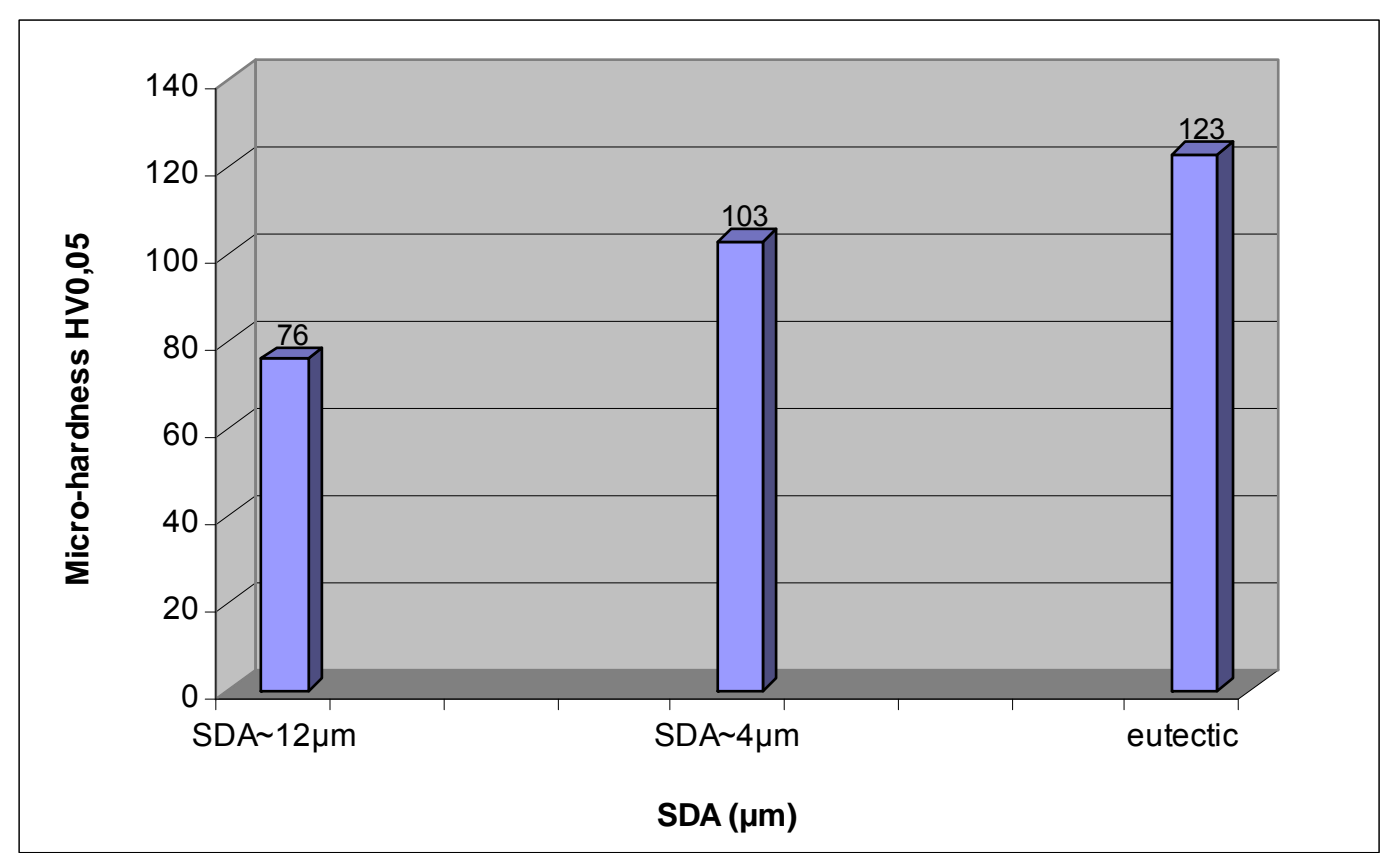

Figure 4.50 Micro-hardness measurements of the as cast demo-axial sample at the different locations in the sample

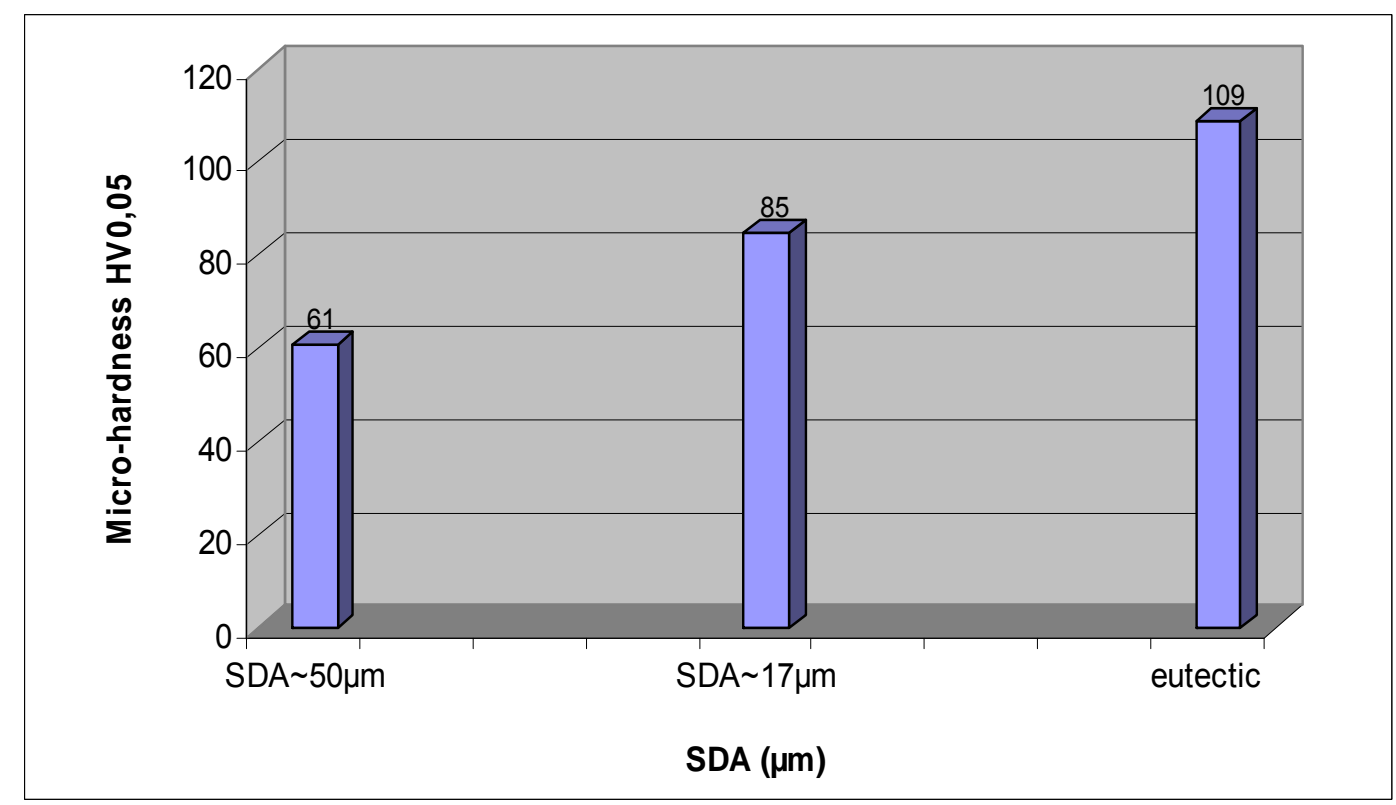

Figure 4.51 Micro-hardness measurements of the demo-axial sample after heat treatment $\left(350^{\circ} \mathrm{C} / 2 \mathrm{~h}\right)$ at the different locations on the sample 


\subsection{Thermal analysis}

The results of isothermal dilatometry of AlSi7Mg0.3 and pure $\mathrm{Al}(99.8 \%)$ at different temperatures and holding time are shown in Figure 4.52.

First steps

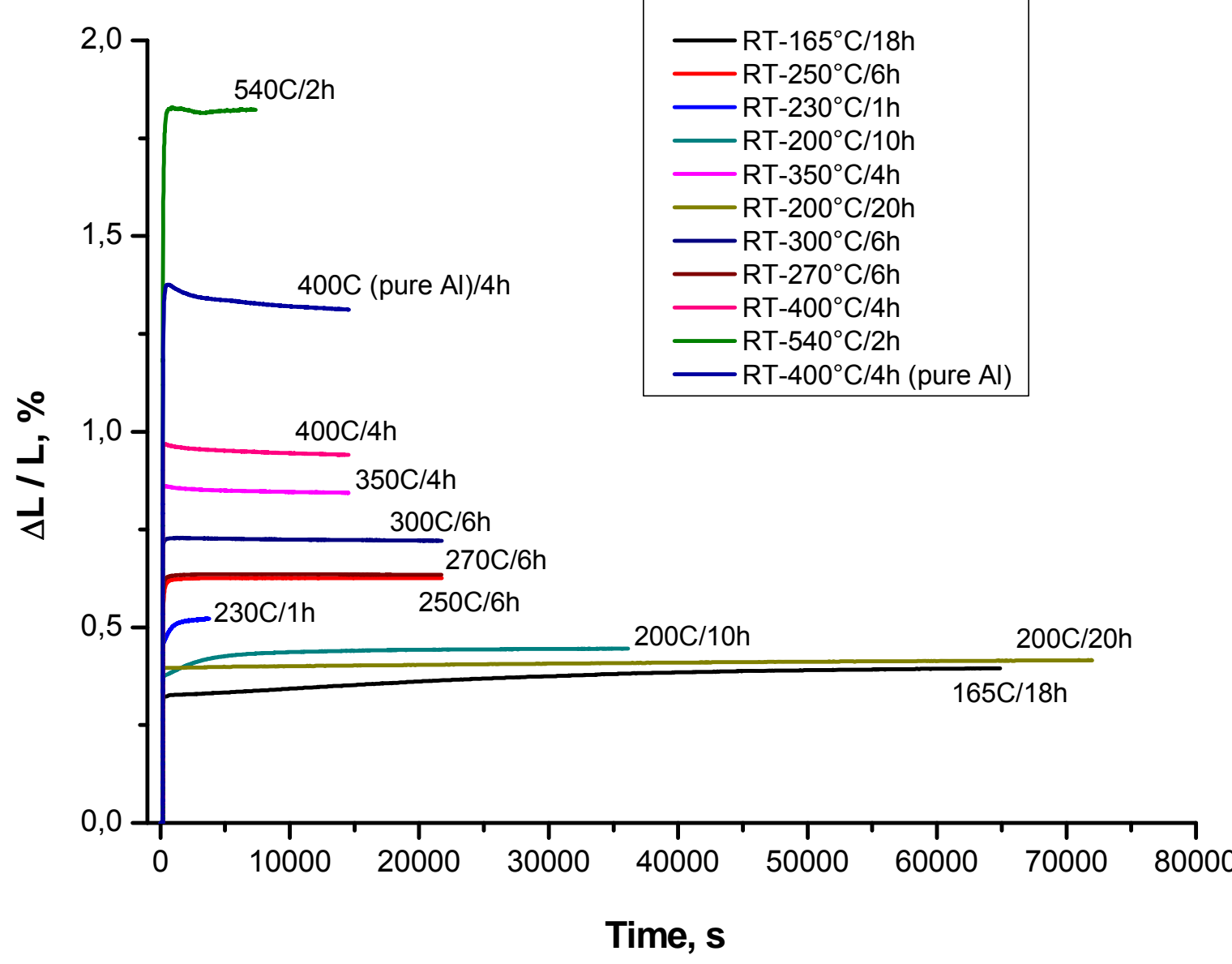

Figure 4.52 Isothermal dilatometry of AISi7Mg0.3 and Al (99.8\%) according to the Bähr dilatometry test indicated in Figure 3.32-3.37 (first step) 
- First step (see Figure 3.32 - 3.37)

\begin{tabular}{|l|c|c|}
\hline \multicolumn{1}{|c|}{ as cast } & $\begin{array}{c}\text { solution treated, cooling } \\
\mathbf{5 0 K} / \mathbf{m i n}\end{array}$ & $\begin{array}{c}\text { solution treated, cooling } \\
\mathbf{2 0 K} / \mathbf{m i n}\end{array}$ \\
\hline $165^{\circ} \mathrm{C}: 0.07 \% / 18 \mathrm{~h}$ & & \\
\hline $200^{\circ} \mathrm{C}: 0.065 \% / 10 \mathrm{~h}$ & & \\
\hline $230^{\circ} \mathrm{C}:+0.06 \% / 1 \mathrm{~h}$ (precipitation) & $230^{\circ} \mathrm{C}:+0.04 \% / 6 \mathrm{~h}$ & $250^{\circ} \mathrm{C}:+0.03 \% / 10 \mathrm{~h}$ \\
\hline $250^{\circ} \mathrm{C}:-0.08 \% / 7 \mathrm{~h}$ & & $300^{\circ} \mathrm{C}:-0.009 \% / 8 \mathrm{~h}$ \\
\hline $300^{\circ} \mathrm{C}:-0.008 \% / 6 \mathrm{~h}$ & $350^{\circ} \mathrm{C}:-0.03 \% / 5 \mathrm{~h}$ \\
\hline $350^{\circ} \mathrm{C}:+0.086 \% / 4 \mathrm{~h}$ & $400^{\circ} \mathrm{C}: / 4 \mathrm{~h}$ \\
\hline $400^{\circ} \mathrm{C}: 0.3 \%(\mathrm{Si} \mathrm{dissolved)}$ \\
$1.3 \% \mathrm{Si} \mathrm{precipitated} \mathrm{before}$ \\
reaching $400^{\circ} \mathrm{C}$
\end{tabular}

- Second step (see Figure 4.53 - 4.56)

\begin{tabular}{|c|l|}
\hline $165^{\circ} \mathrm{C}----\rightarrow 250^{\circ} \mathrm{C}$ & $\begin{array}{l}\text { further growth }+0.02 \% / 1.5 \mathrm{~h}=0.09 \% \\
1 \mathrm{~h} \text { expanding after } 2.5 \mathrm{~h} \text { contraction, total expansion } 0.07 \%\end{array}$ \\
\hline $200^{\circ} \mathrm{C}----\rightarrow 270^{\circ} \mathrm{C}$ & $\begin{array}{l}\leq 2 \mathrm{~h} \text { growth }+0.005 \%=0.07 \%, \\
\text { than shrinkage }-0.0025 \% / 5 \mathrm{~h}\end{array}$ \\
\hline & \\
\hline $230^{\circ} \mathrm{C}----\rightarrow 300^{\circ} \mathrm{C}$ & $\begin{array}{l}15 \text { min growth }+0.003 \%=0.09 \%, \\
\text { than shrinkage }-0.009 \% / 6 \mathrm{~h}\end{array}$ \\
\hline $250^{\circ} \mathrm{C}----\rightarrow 350^{\circ} \mathrm{C}$ & $\begin{array}{l}0.009 \% \text { corresponds to reduced solubilities }(\sim 0.1 \% \mathrm{wt} \% \mathrm{Si}) \\
+0.03 \%\end{array}$ \\
\hline
\end{tabular}




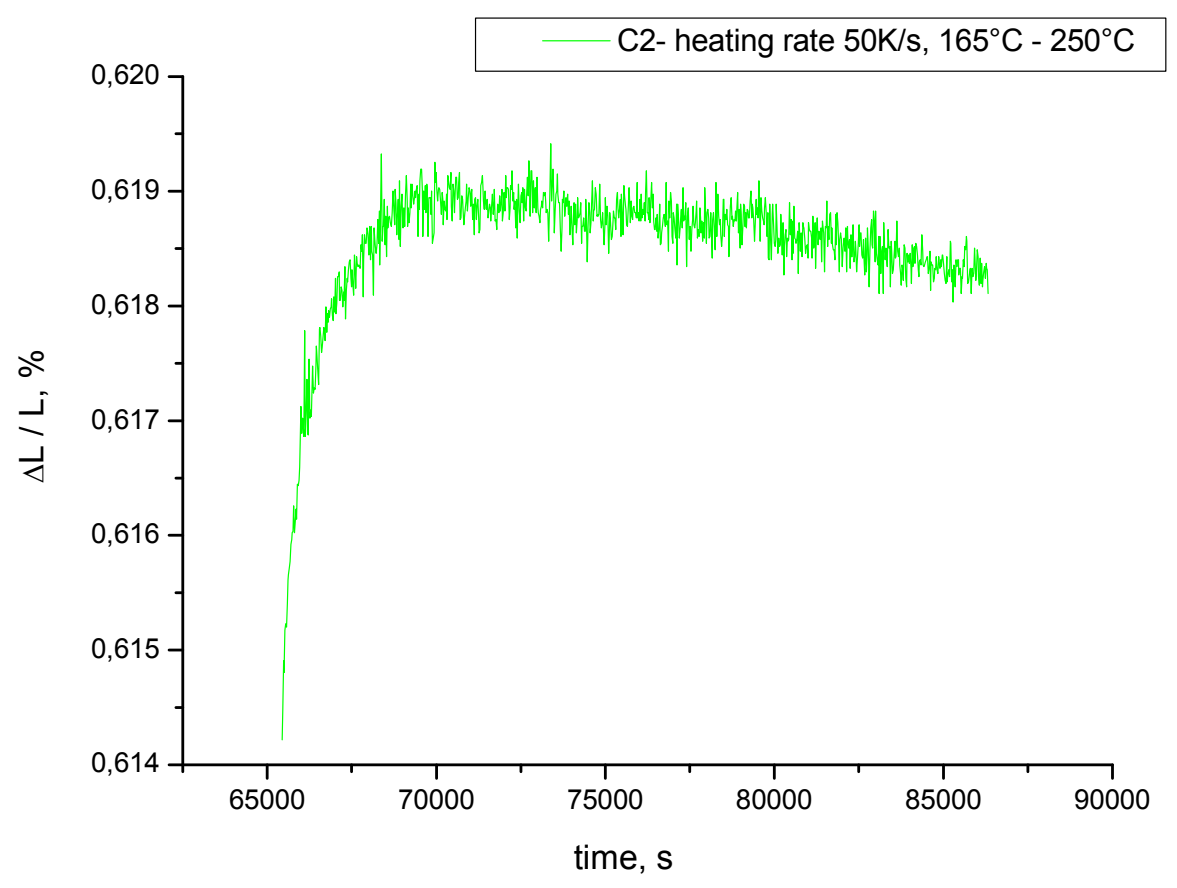

Figure 4.53 Isothermal dilatometry of step cast sample with heating rate of $50 \mathrm{~K} / \mathrm{s}$, sketch of the measurements is shown in Figure 3.32

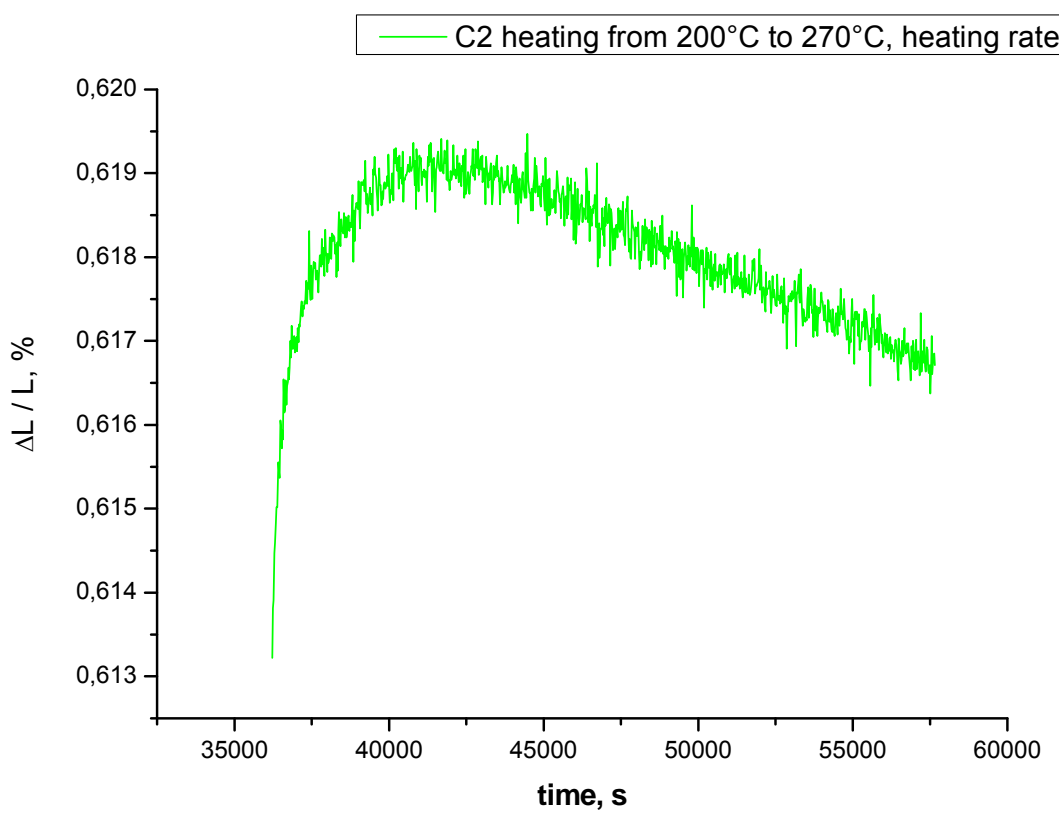

Figure 4.54 Isothermal dilatometry of step cast sample with heating rate of $50 \mathrm{~K} / \mathrm{s}$, sketch of the measurements is shown in Figure 3.34 (Test 1) 


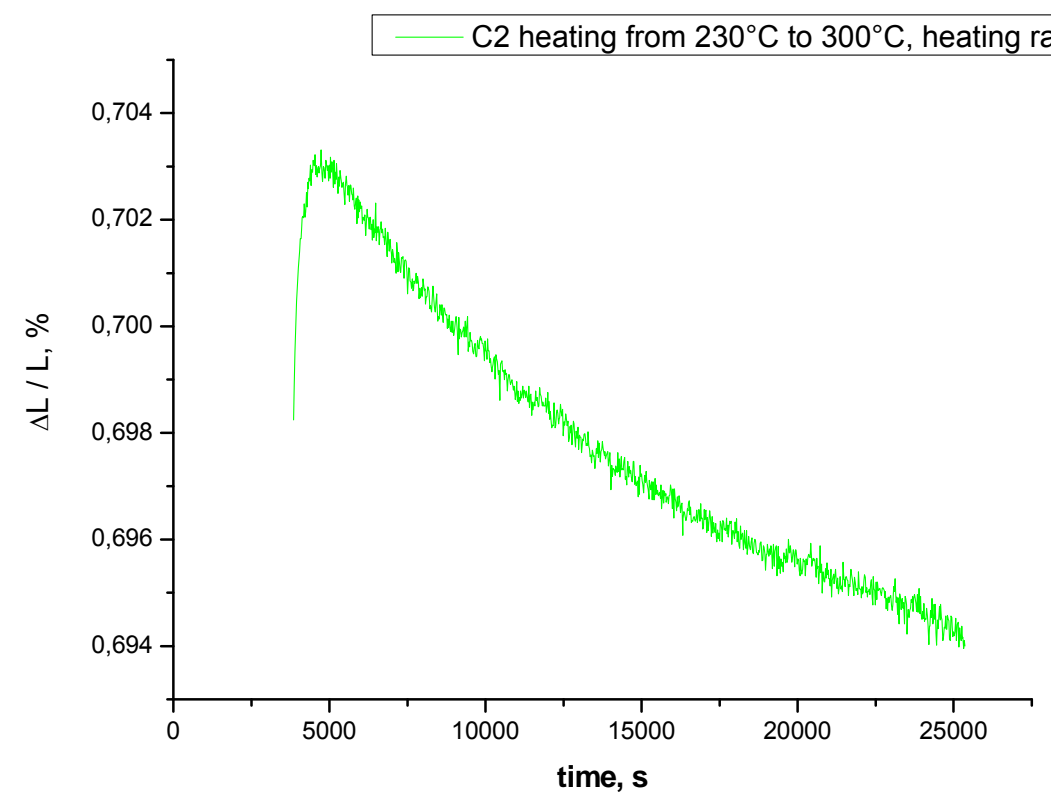

Figure 4.55 Isothermal dilatometry of step cast sample with heating rate of $50 \mathrm{~K} / \mathrm{s}$, sketch of the measurements is shown in Figure 3.36 (Test 3)

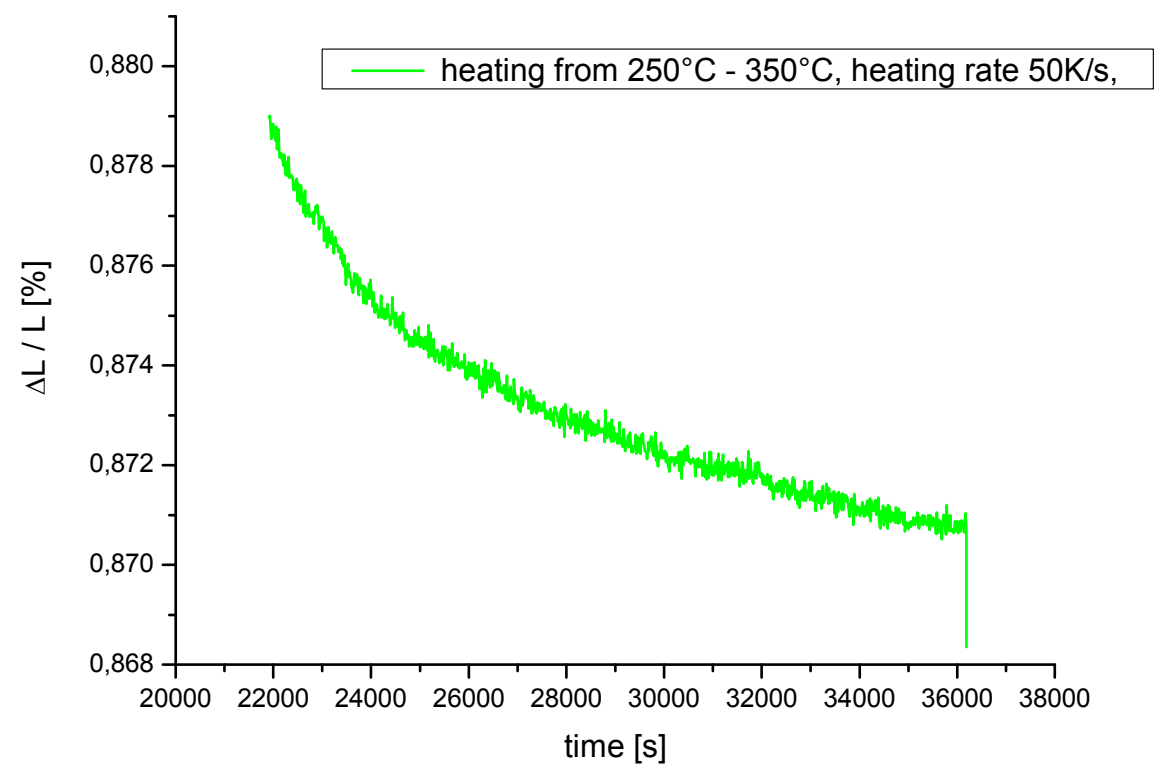

Figure 4.56 Isothermal dilatometry of step cast sample (AlSi7Mg) with heating rate of $50 \mathrm{~K} / \mathrm{s}$ (sketch of the measurements is shown in Figure 3.32) 


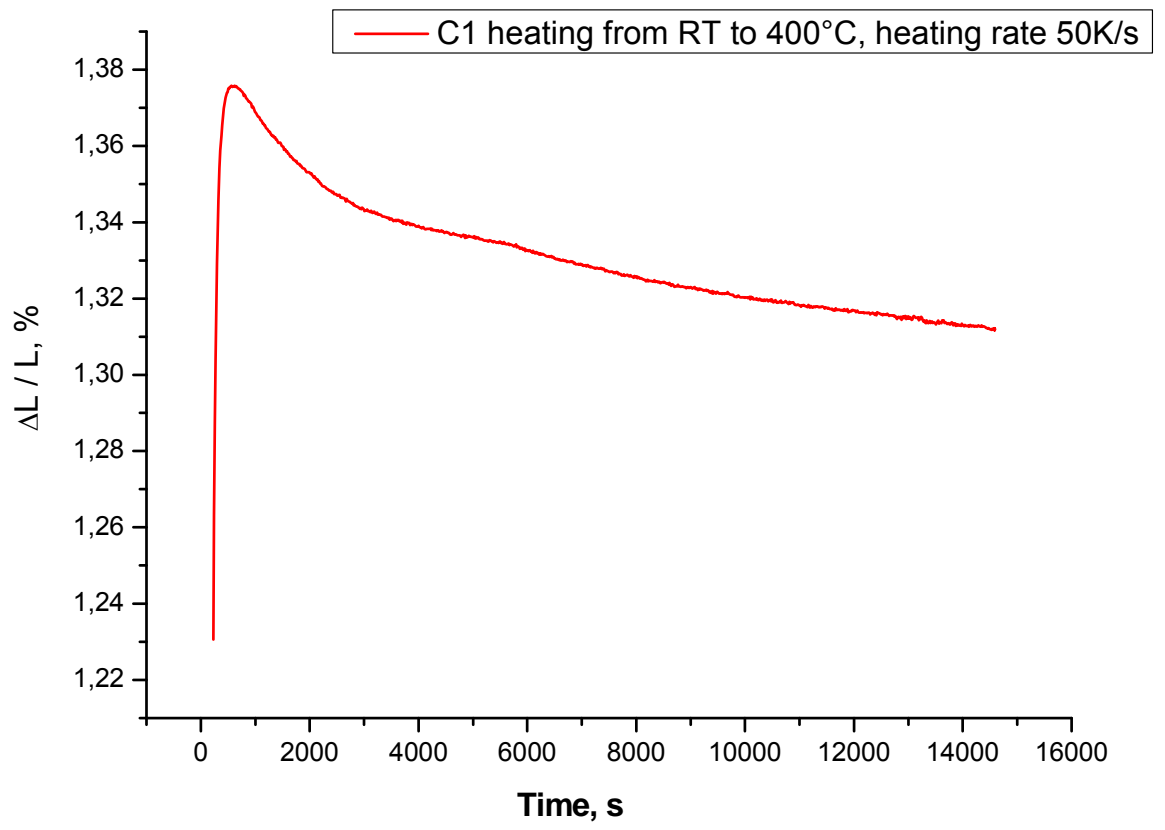

Figure 4.57 Isothermal dilatometry of pure aluminium (99.8\%) with heating rate of $50 \mathrm{~K} / \mathrm{s}$, (sketch of the measurements is shown in Figure 3.33)

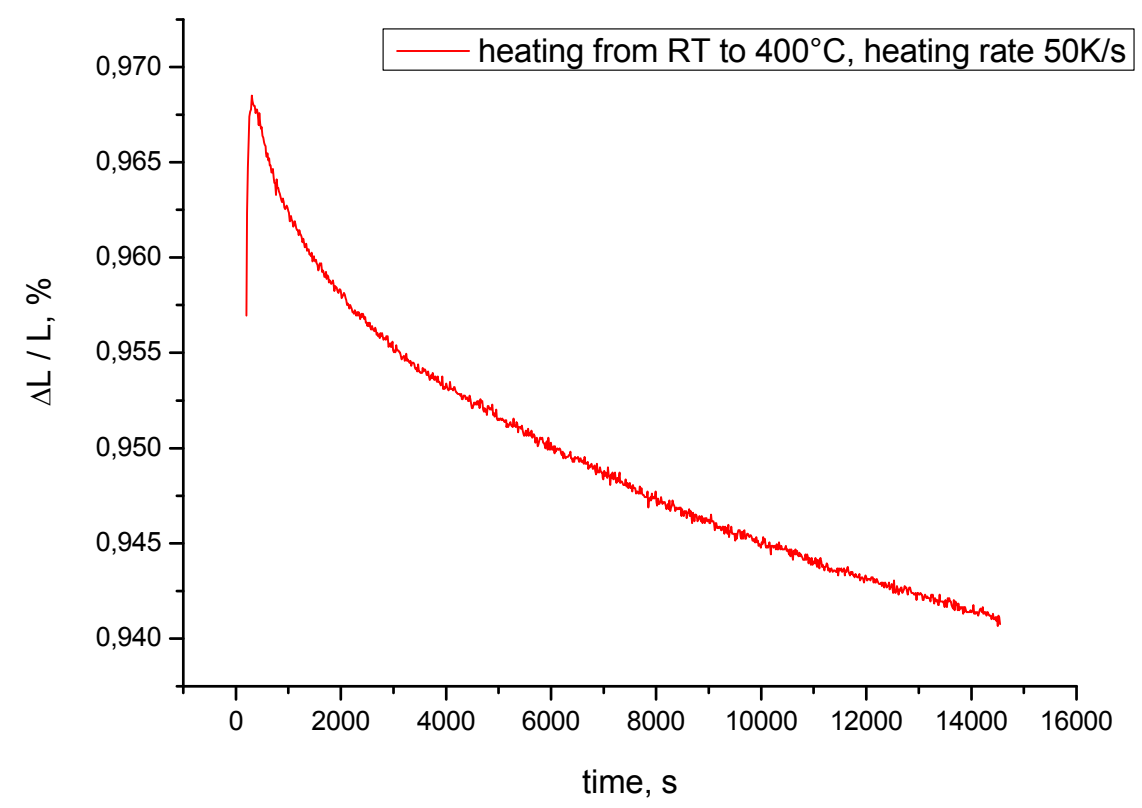

$0.8 \%$ Si precipitated during heating (almost equilibrium)

Figure 4.58 Isothermal dilatometry of AISi7Mg0.3 of step sample with heating rate of $50 \mathrm{~K} / \mathrm{s}$ and cooling rate of $20 \mathrm{~K} / \mathrm{min}$ (see sketch of the measurement depicts in Figure 3.31) 
Figure 4.59 shows several DSC runs of AlSi7Mg0.3 alloy (step and demo-axial sample) at different thermal conditions measured at $5 \mathrm{~K} / \mathrm{min}$. As cast and after $165^{\circ} \mathrm{C}$ condition present an exothermic effect between $180-300^{\circ} \mathrm{C}$ (heating rate $=5 \mathrm{~K} / \mathrm{min}$ ). No exothermic effect was observed in step sample in the $250^{\circ} \mathrm{C} / 5 \mathrm{~h}$ condition. Condition of $165^{\circ} \mathrm{C} / 10 \mathrm{~h}$ shows a small exothermic effect between $200-300^{\circ} \mathrm{C}$ after heating at $5 \mathrm{~K} / \mathrm{min}$ in DSC apparatus.

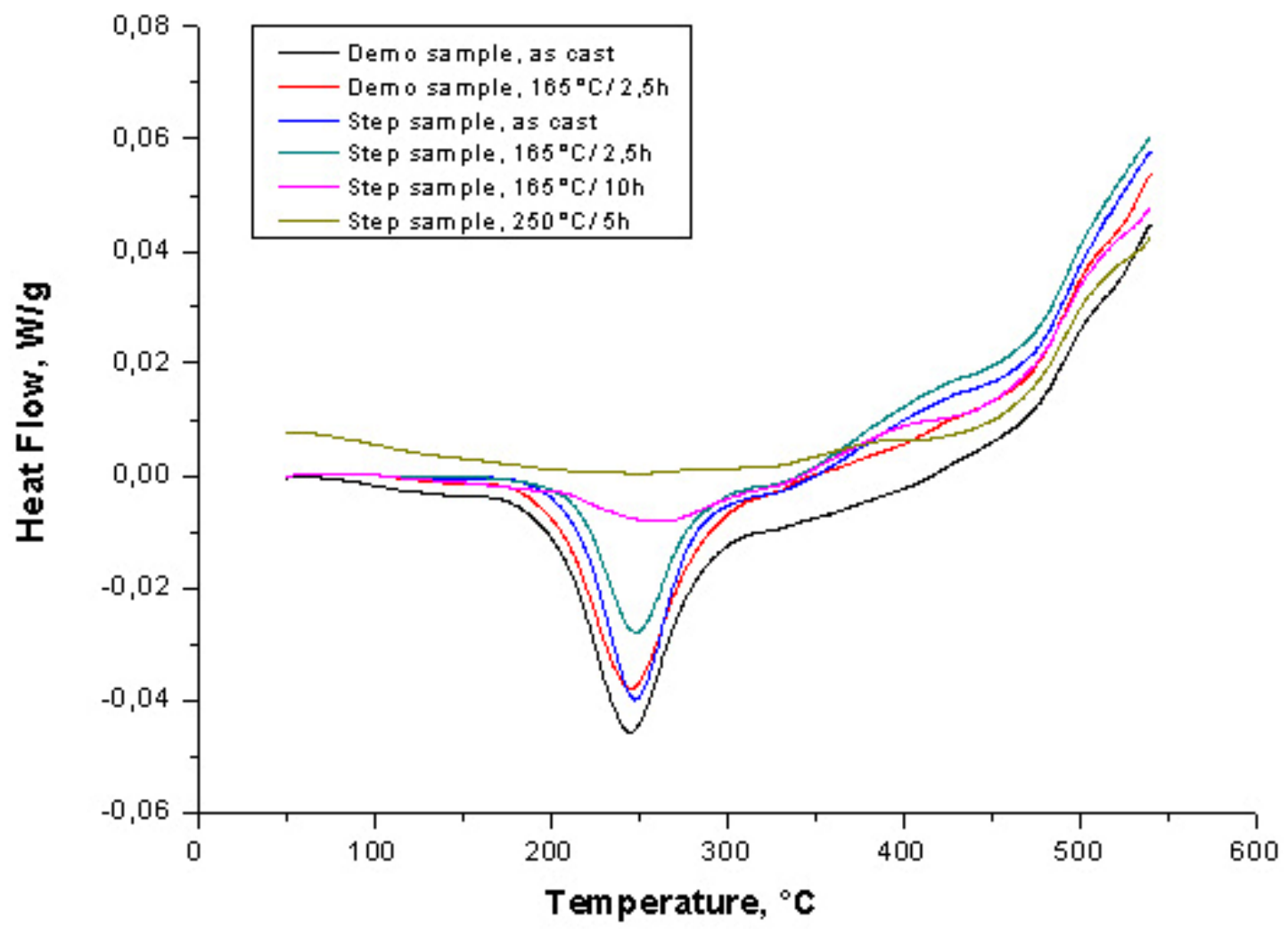

Figure 4.59 DSC thermo-grams of AlSi7Mg0.3 at $5 \mathrm{~K} / \mathrm{min}$ in different thermal condition

\subsection{Compression test}

The flow curves at $1 \mathrm{~s}^{-1}$ and a temperature ranging from $140^{\circ} \mathrm{C}$ to $350^{\circ} \mathrm{C}$ in as cast conditions is shown in Figure 4.60. The stress-strain curves of the AlSi7Mg0.3 (step sample) shows flow curve for the test with the $\mathrm{T}<350^{\circ} \mathrm{C}$ (see Figure $3.41 \mathrm{a}$ ). Flow stress decreases with increases in deformation temperature.

Figure 4.61 shows the flow curves of the ranging temperatures from $350^{\circ} \mathrm{C}$ to $530^{\circ} \mathrm{C}$ (see Figure 3.41 b). Flow stress increases with decreasing the deformation temperature and increasing the strain rate. 


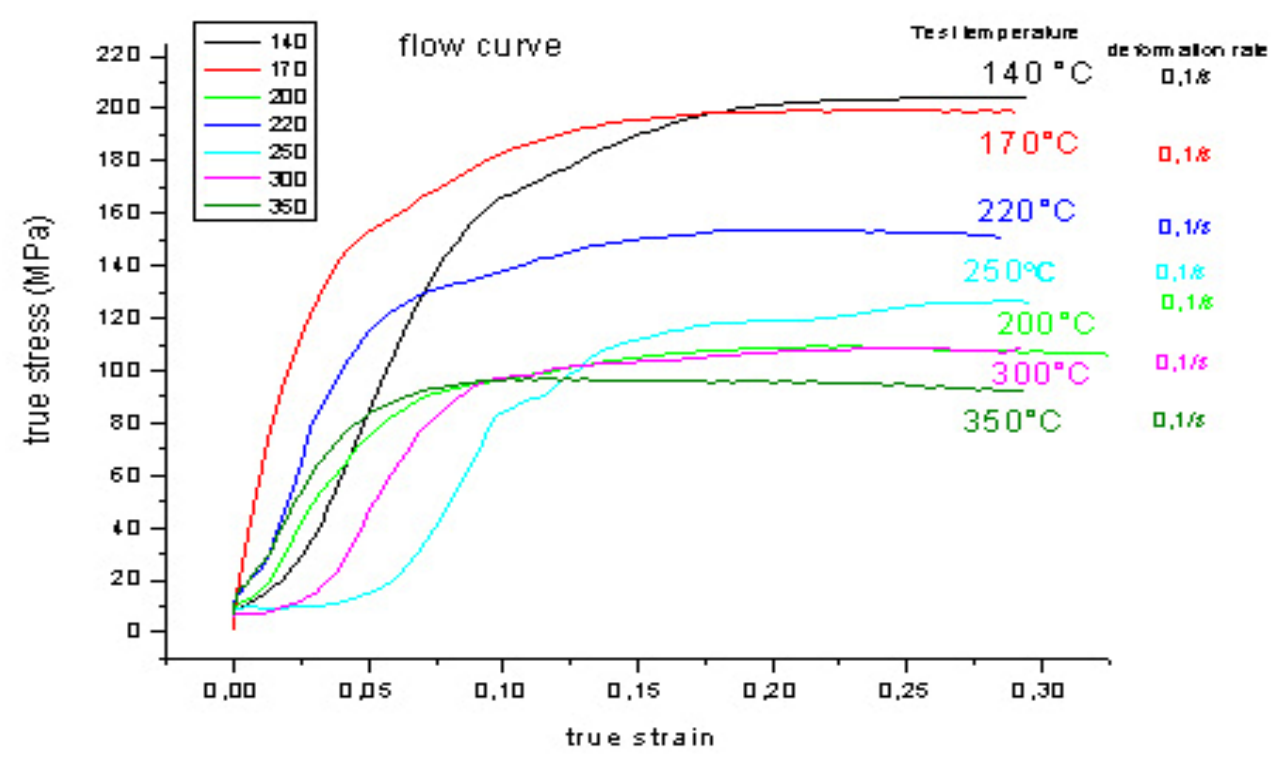

Figure 4.60 Shows the flow curve for the test series $\mathrm{Nr} 1\left(\mathrm{~T} \leq 350^{\circ} \mathrm{C}\right)$

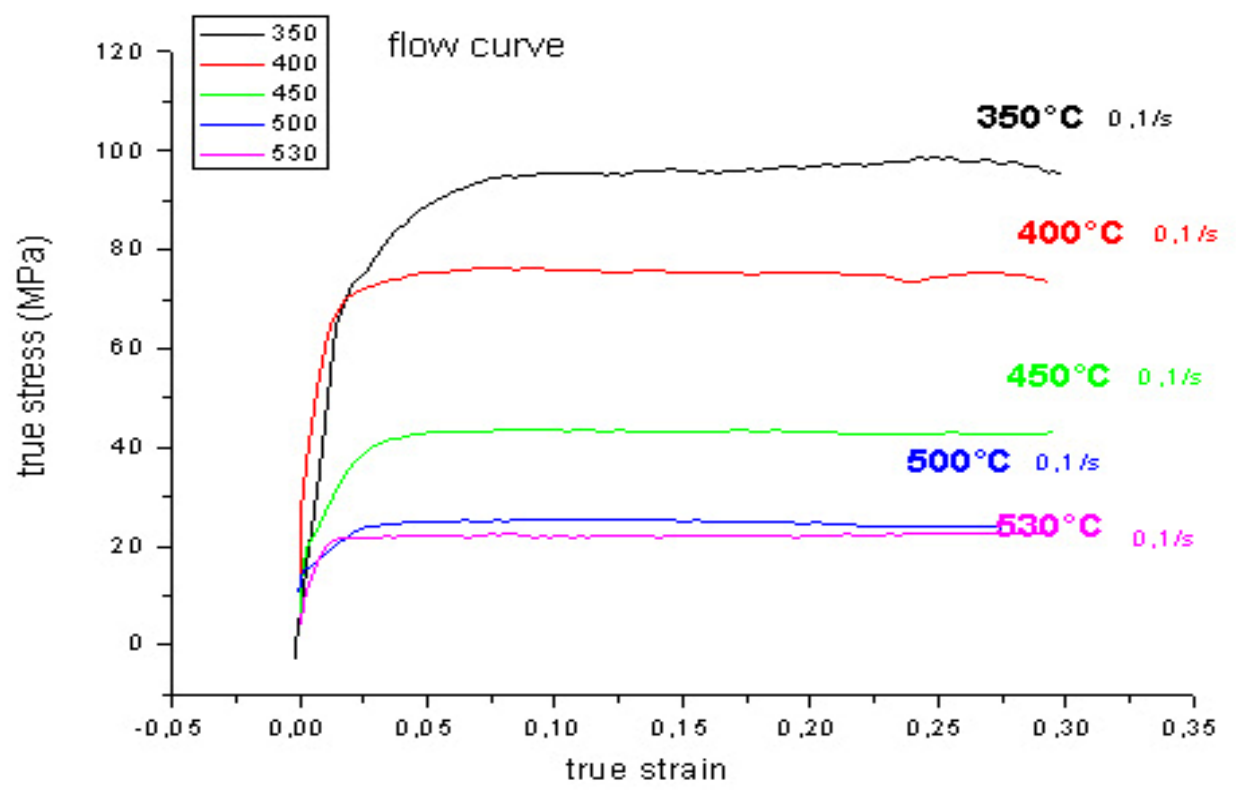

Figure 4.61 Shows the flow curve for the test series $\mathrm{Nr} 2\left(T \geq 350^{\circ} \mathrm{C}\right)$ 


\subsection{Residual stresses}

Figure 4.63 shows a stress analysis by X-ray diffraction of the step sample 10 of the $\mathrm{Al}$ in the cast alloy along a radial line from the steel interface compared with stress values in Al measured in AlSi7 without steel insert. The tangential stress increases towards the interface to 40MPa tension (stress changes from -90MPa to +30MPa by about 110MPa), [68].

Compressive stresses exist in the Al of the Al-Si casting after quenching even without any steel insert. The thermal mismatch between the Al and the Si-phase causes thermal misfit stresses as shows in Figure 4.63. Only the region close to the interface to the steel insert shows tangential tensile stresses in Figure 4.63. The residual stress in the radial direction amounts to $-90 \pm 30 \mathrm{MPa}$. The compressive level of in the $\mathrm{Al}$ Matrix seems to represent the stress originated from the quenching of the bulk and from the grinding preparation (Figure 4.64) shows the residual stresses within Al and $\mathrm{Si}$ after grinding AlSi7 from different temperatures: the compressive radial stresses in Al around $\mathrm{Si}$ inclusions dominate the tensile hoop stresses [69].

Table 4.62 Results: after quenching

\begin{tabular}{|c|c|c|}
\hline & $\sigma_{\mathbf{r}}[\mathrm{MPa}]$ & $\boldsymbol{\sigma}_{\mathbf{t}}[\mathrm{MPa}]$ \\
\hline Al0 & -44 & 34 \\
\hline Al5 & -36 & -51 \\
\hline Al10 & -84 & -54 \\
\hline Al15 & -84 & -97 \\
\hline Al20 & -55 & -86 \\
\hline Al25 & -68 & \\
\hline
\end{tabular}

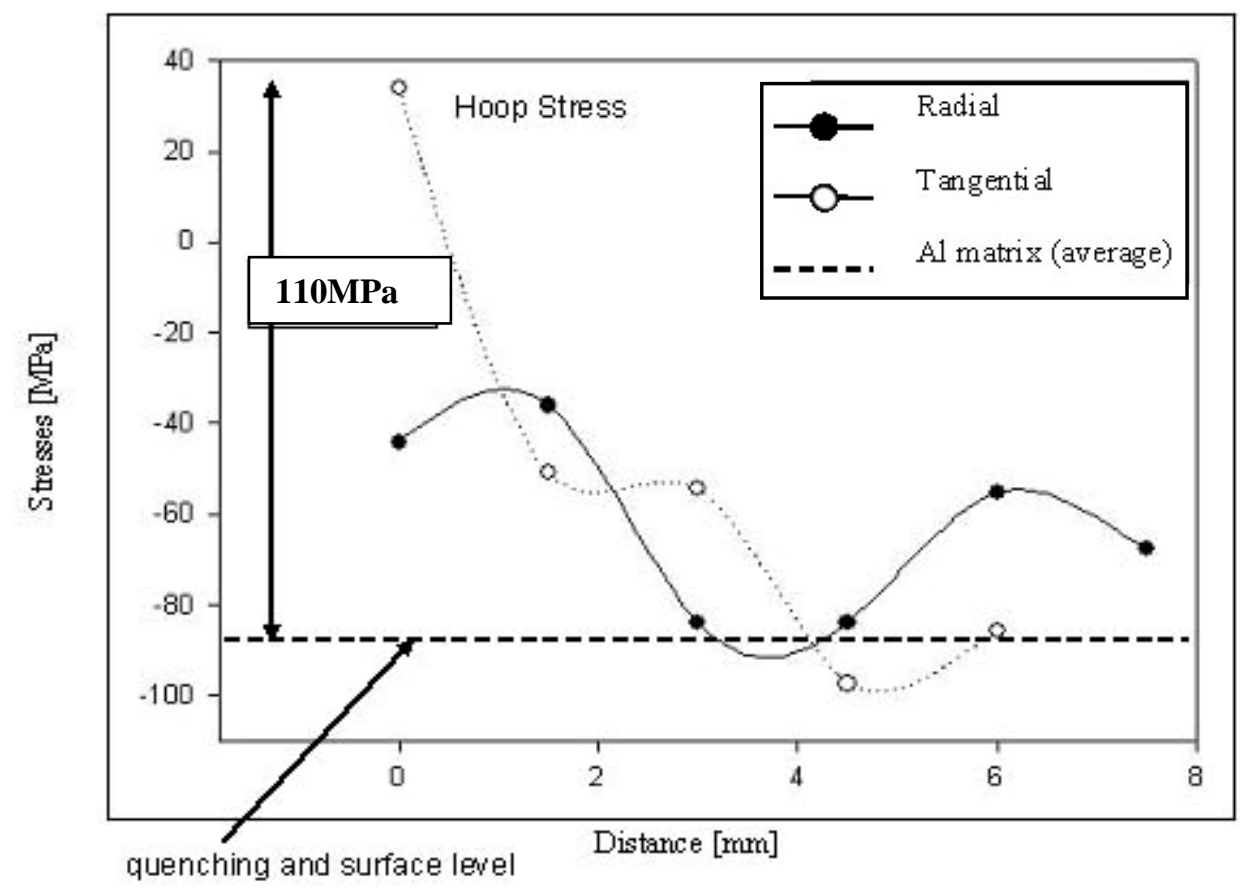

Figure 4.63 Stress analysis by X-ray diffraction of the Al in the cast alloy quenched from $350^{\circ} \mathrm{C}$ along a radial line from the steel interface compared with stress values measured in AlSi7 without steel insert 


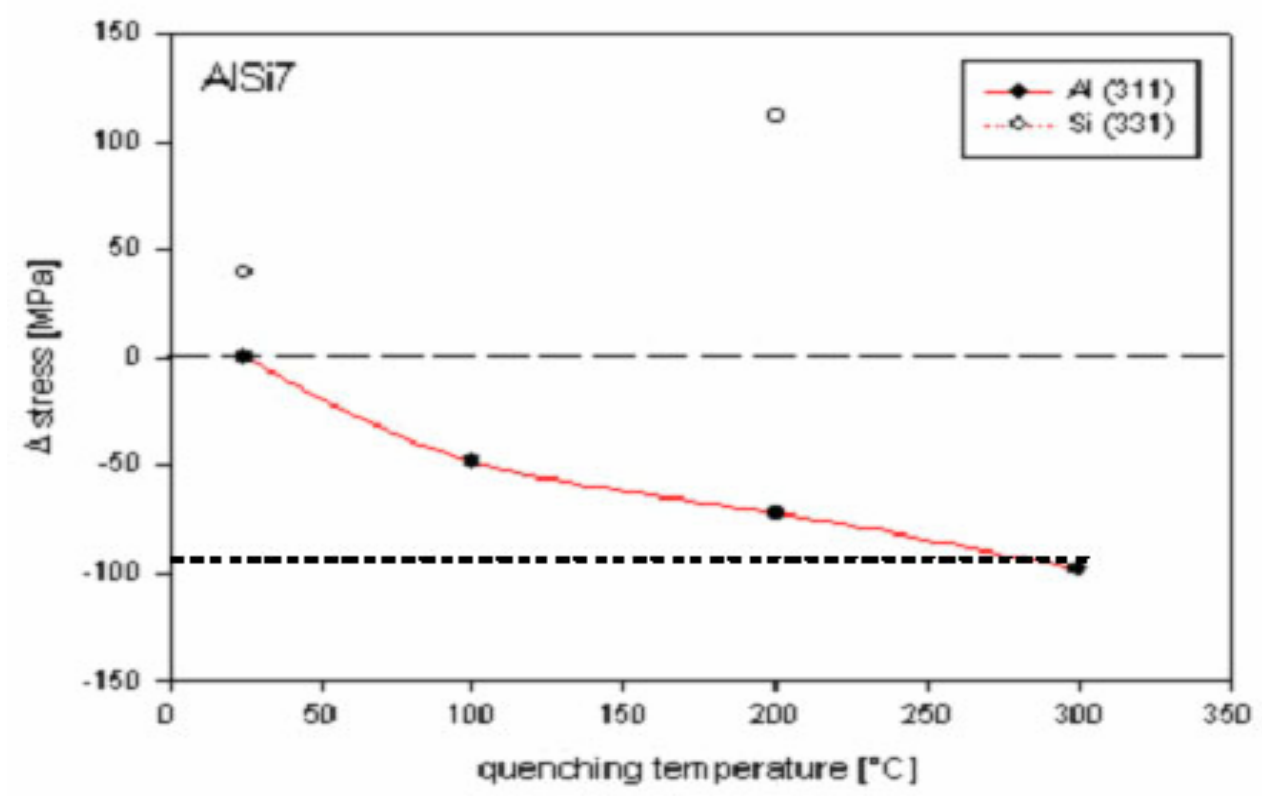

Figure 4.64 Stress change in Al and Si in AlSi7 alloy without insert after quenching from different temperatures (neutron diffraction results)

Figure 4.63 shows the stress analysis of the investigated Al casting after quenching from $350^{\circ} \mathrm{C}$. Compressive stresses evolve in the Al of the Al-Si casting with increasing quenching temperature even without any steel insert.

The thermal mismatch between the Al and the Si-phase causes thermal misfit stresses as shown in Table 4.65. Only the region close to the interface to the steel insert shows tangential tensile stresses in Figure 4.63, resulting from adding ca. $110 \mathrm{MPa}$ to the level of -90MPa compressive stress in Al.

Table 4.65 Results: after quenching from $350^{\circ} \mathrm{C}$

\begin{tabular}{|c|c|c|}
\hline & Aluminium & Steel \\
\hline phi & or [MPa] & or [MPa] \\
\hline $0^{\circ}$ & -62 & -232 \\
\hline $45^{\circ}$ & -40 & -236 \\
\hline $90^{\circ}$ & -44 & -218 \\
\hline $135^{\circ}$ & -54 & -218 \\
\hline $180^{\circ}$ & -79 & -248 \\
\hline $225^{\circ}$ & -91 & -287 \\
\hline $270^{\circ}$ & -52 & -202 \\
\hline $315^{\circ}$ & -54 & -202 \\
\hline
\end{tabular}

Figure 4.66 gives the distribution of radial stresses in Al around $1 \mathrm{~mm}$ outside the steel interface and $1 \mathrm{~mm}$ inside in steel. The compressive stress in steel surpasses 200MPa whereas that in $\mathrm{Al}$ is below $100 \mathrm{MPa}$ approximately the yield strength of pure Al. 
Radial stresses on the Al-Steel Interface

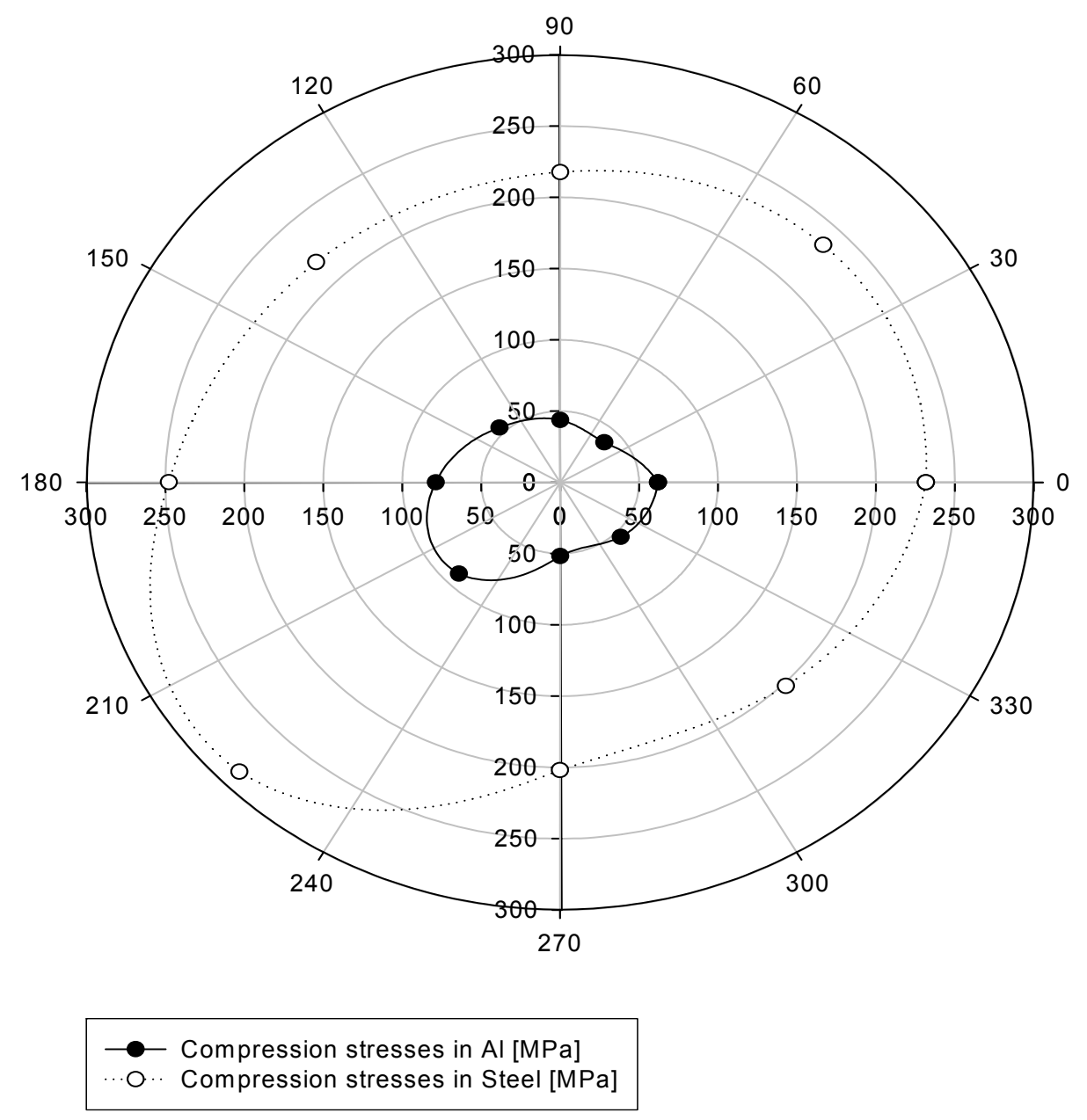

Figure 4.66 Radial stress analysis after quenching from $350^{\circ} \mathrm{C}$ (see Table 4.65) for the Al casting and steel close to the interface in the middle plane 


\subsection{Pull out test}

Figure 4.67 shows results of the pull out test of the steel tubes from the as cast and heat treated demo-axial sample. The samples can resist high enough static loads, for example a tensile axial load of $26 \mathrm{kN}$ (S 22). Interface reaction seems to be of on effect to the bonding strength tested in tensile test. The highest value is observed in the peak aged sample 22. The bonding strength depends on heat treatment of the alloy.

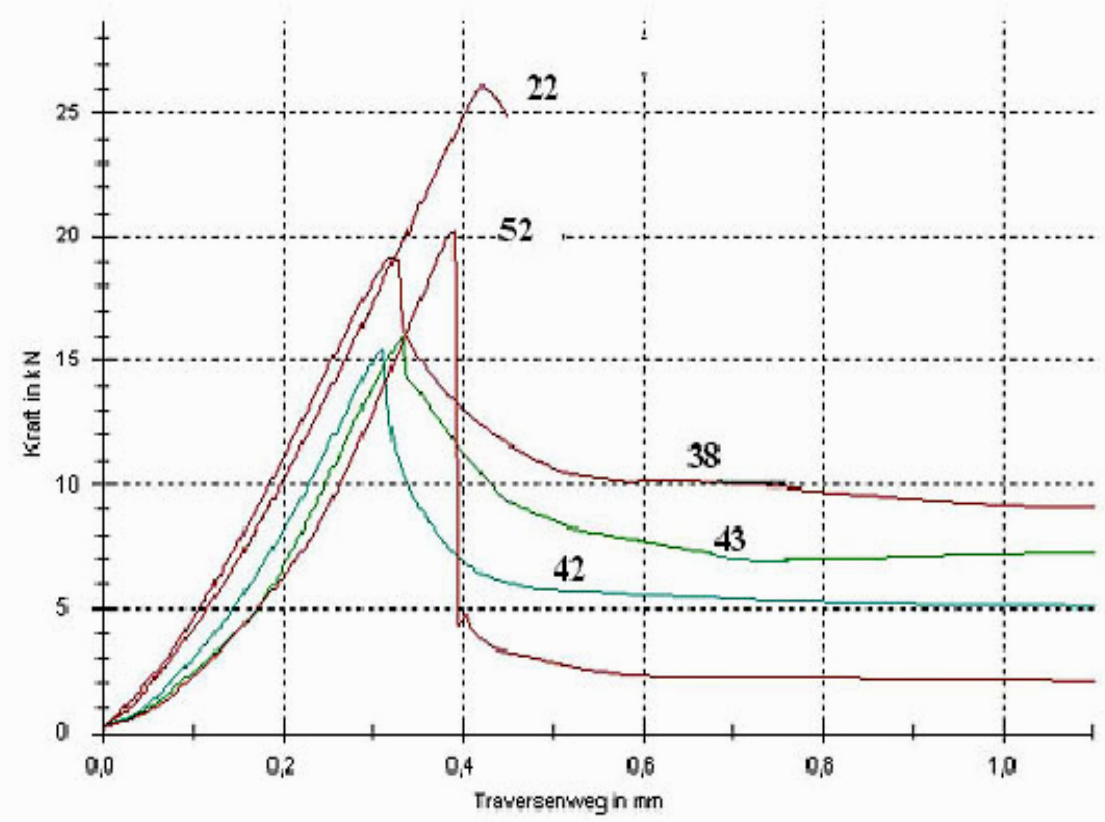

\begin{tabular}{|c|c|c|}
\hline Sample & Condition & HB \\
\hline 22 & $165^{\circ} \mathrm{C} / 2,5 \mathrm{~h}$ & 89 \\
\hline 52 & $250^{\circ} \mathrm{C} / 5 \mathrm{~h}$ & 77 \\
\hline 38 & $350^{\circ} \mathrm{C} / 2 \mathrm{~h}$ & 57 \\
\hline 43 & As cast & 83 \\
\hline \hline 42 & As cast & 83 \\
\hline
\end{tabular}

Figure 4.67 Pull out test of the steel tubes from the as cast and heat treated demo-axial sample: force versus displacement curves

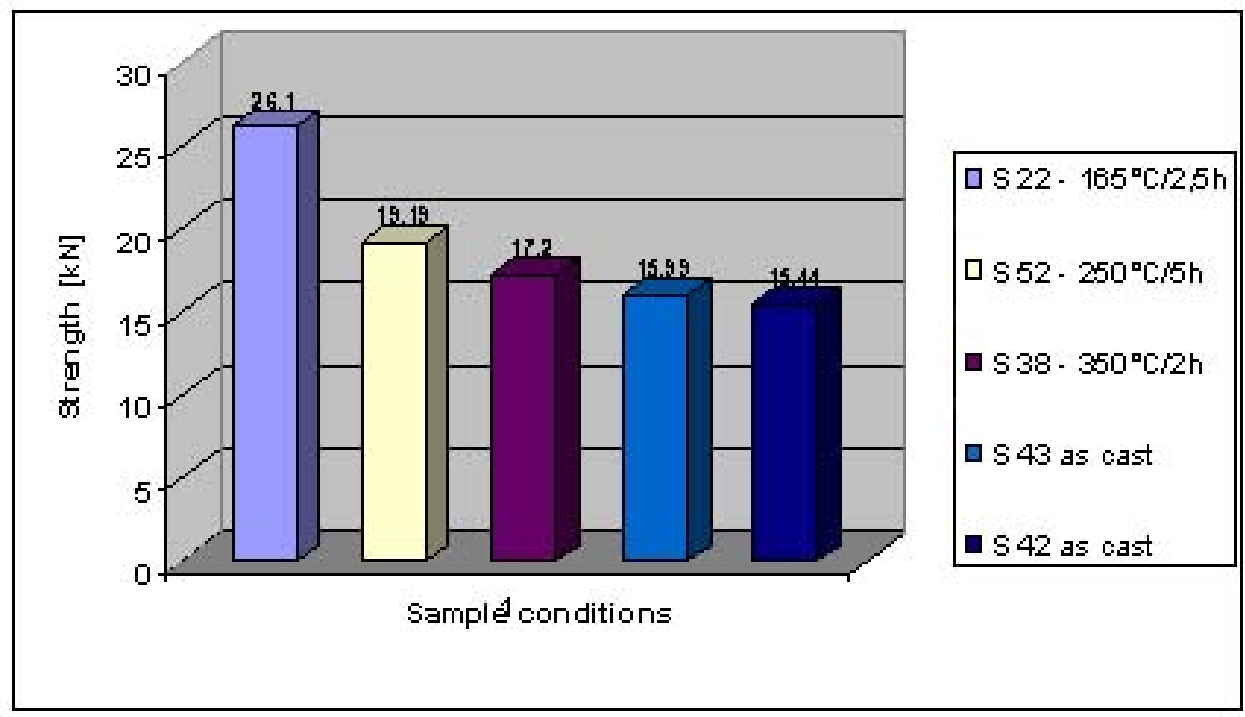

Figure 4.68 Pull out stress of the demo-axial sample carried out in the different thermal conditions 


\subsection{Laser Ultrasound measurements on steel-aluminium tube}

Figure 4.69 shows the measurement result for an entire $360^{\circ}$ rotation at a certain Xvalue. The first arriving longitudinal bulk wave can be identified at approximately $2.4 \mu \mathrm{s}$. Between $170^{\circ}$ and $250^{\circ}$ rotation a defect can be identified easily by very low signal amplitude. This defect can be interpreted as debonding between steel and aluminium. Figure $4.70 \mathrm{~A}$ shows the maximum amplitudes between $2 \mu \mathrm{s}$ and $3 \mu \mathrm{s}$ (the green lines in Figure $4.69 \mathrm{~B}$ along the $\mathrm{X}$-axis and $\varphi$-axis. A defect shows up with very small amplitudes in the region of $10-15 \mathrm{~mm}$ and at angles between $170^{\circ}$ and $250^{\circ}$ (Figure $4.69 \mathrm{~B}$ ). Figure $4.70 \mathrm{~B}$ shows the positions of the maxima, a second defect can be seen at rotation angles between $160^{\circ}$ and $270^{\circ}$ [70].

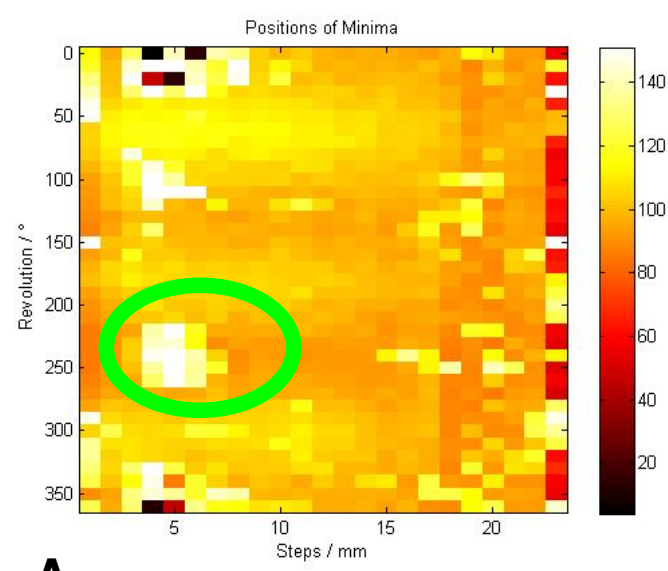

A

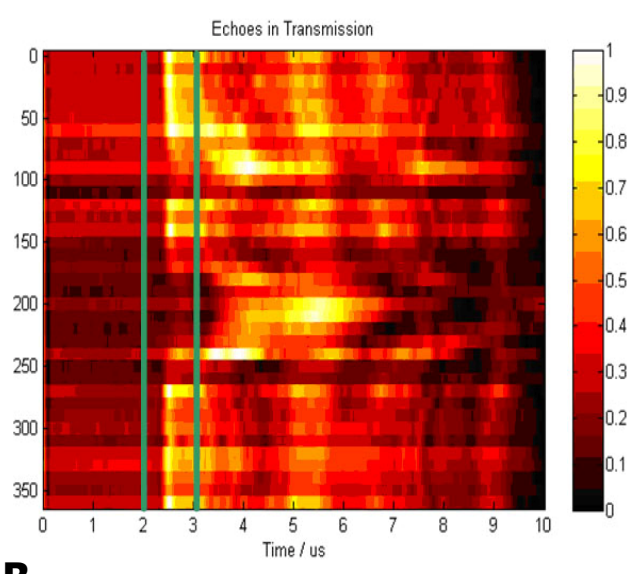

B

Figure 4.69 [70] Shows A) Scan along the surface with the position of the minimum shown, B) Ultrasonic raw data of one $360^{\circ}$ scan

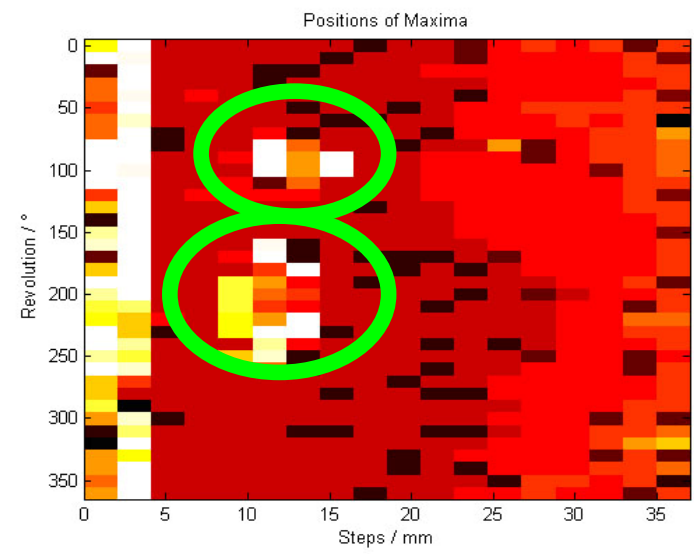

A

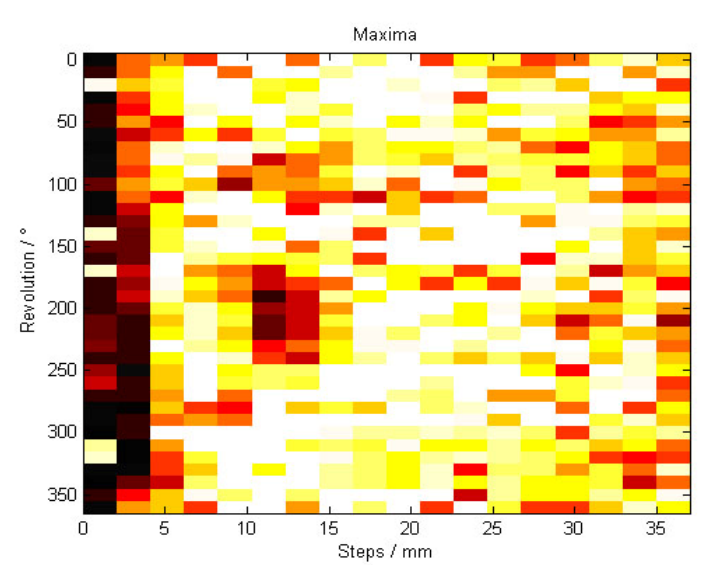

B

Figure 4.70 [70] Shows A) Scan along the inner surface with the position of the maximum shown indicated by brighter colours (later arrival of the longitudinal waves),

B) Scan along the surface of the sample 

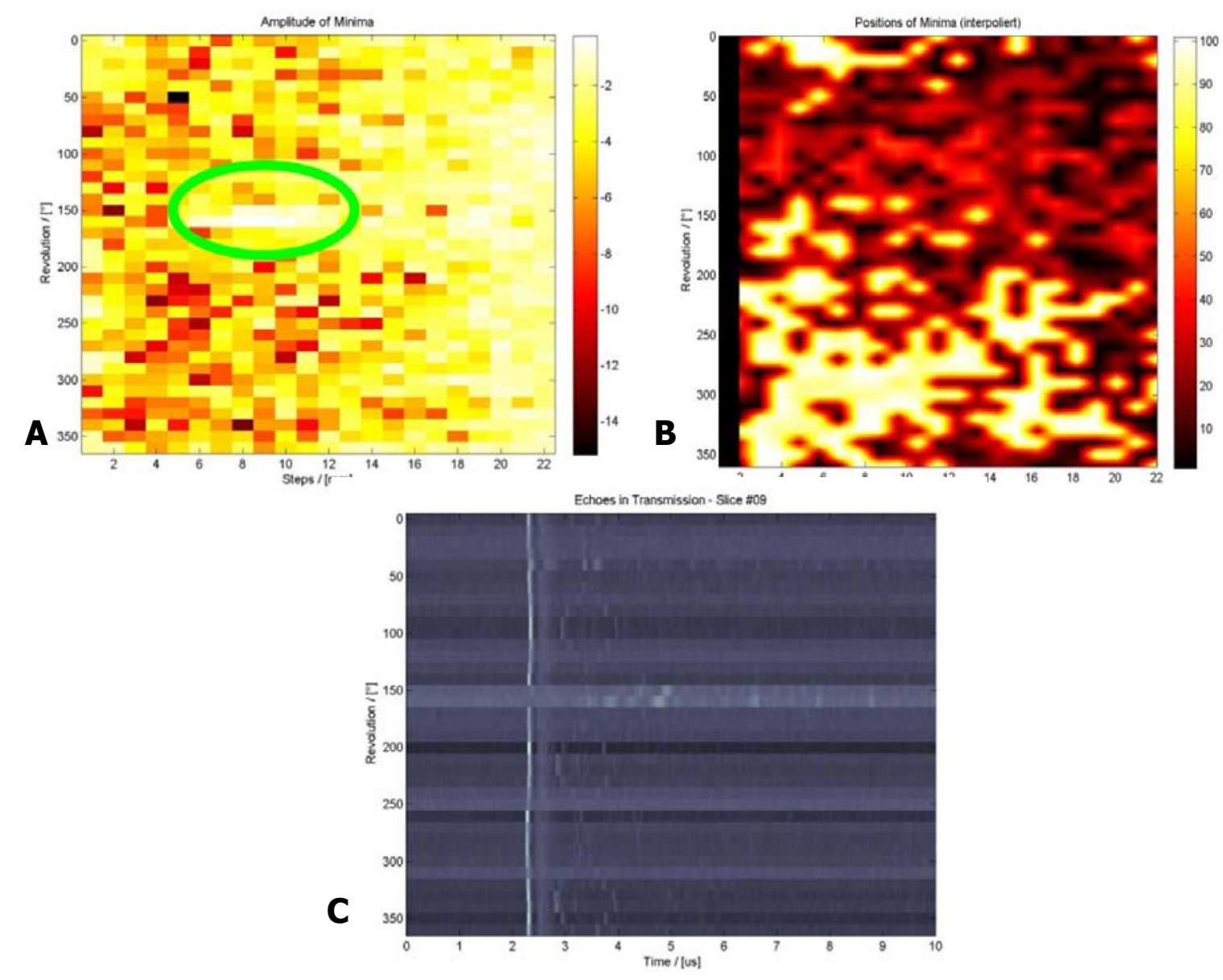

Figure 4.71 [70] Shows A, B) Scan along the surface with the positions of the minimum of the demoaxial sample after aging at $165^{\circ} \mathrm{C} / 2.5 \mathrm{~h} ; \mathrm{C}$ ) Ultrasonic raw data of ninth step of $360^{\circ}$ scan

Figure 4.71 shows the LUS measurements results of demo-axial sample after aging at $165^{\circ} \mathrm{C}$ for $2.5 \mathrm{~h}$, for an entire $360^{\circ}$ rotation at a certain $\mathrm{X}$-value. The first arrival longitudinal bulk wave can be identified at approximately $2.2 \mu \mathrm{s}$. The defect can be interpreted as a debonding between steel and aluminium, which extends in the region $6-13 \mathrm{~mm}$. The position of the defect is marked on the sample in Figure $4.74 \mathrm{~A}$. The microstructure around the gap we can observe in Figure 4.24.

The same sample is shown in Figure 4.72 A with the positions of minima, where the first defect shows up in the region of $1-4 \mathrm{~mm}$ and at angles between $110-140^{\circ}$. The second one, we can observe at an angel between $210-250^{\circ}$ in the region of 10 $17 \mathrm{~mm}$. The defects are shown on the sample (see Figure $4.74 \mathrm{~B}$ ) and used for the microstructure analysis in order to verify the defects.

Sample in as cast condition is shown in Figure 4.73. The defects are observed between $100-125^{\circ}$ and between $240-280^{\circ}$ in a region of $1-4 \mathrm{~mm}$. The defects can be interpreted as a delamination of the materials. The position of the defect is marked on the sample in Figure 4.75. 

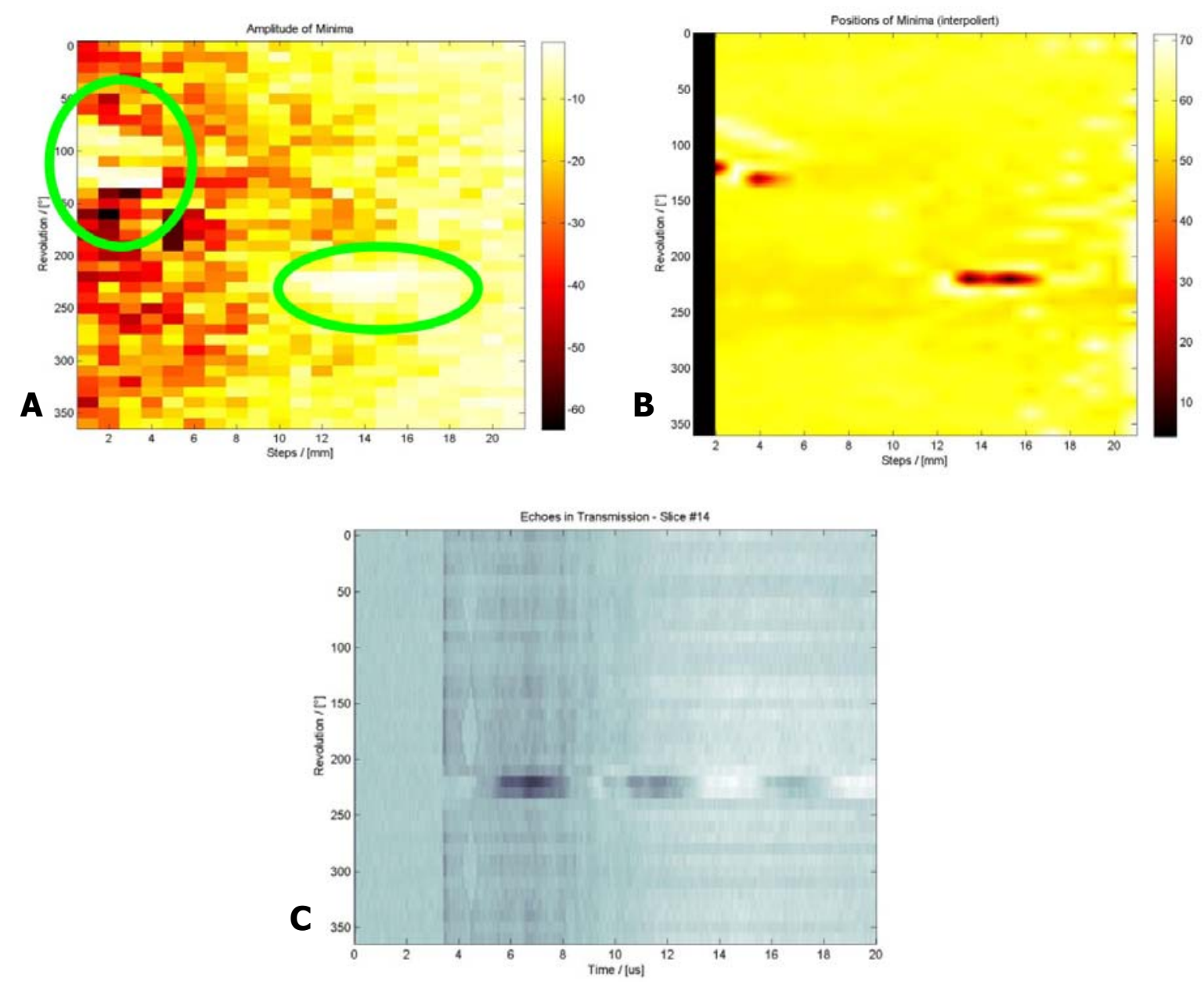

Figure 4.72 [70] Shows A, B) Scan along the surface with the positions of the minimum of the demoaxial sample after aging at $165^{\circ} \mathrm{C} / 2.5 \mathrm{~h}$; C) Ultrasonic raw data of fourteenth step of $360^{\circ}$ scan

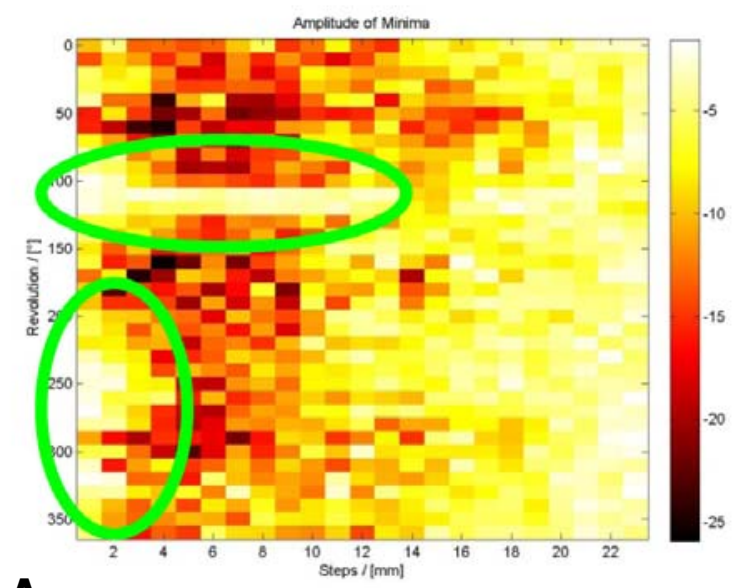

A

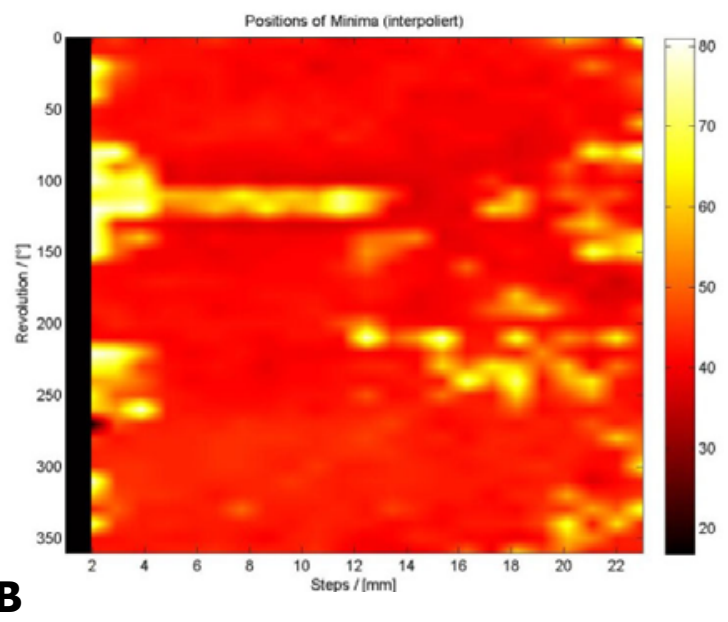




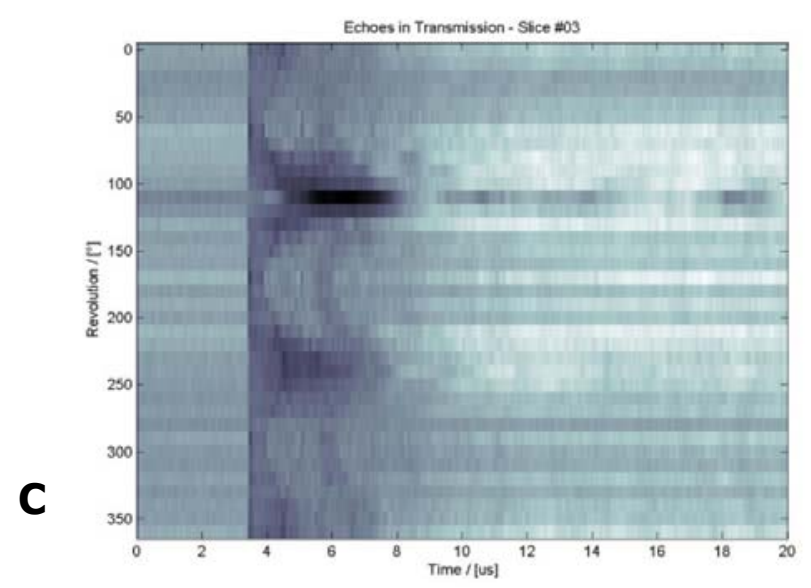

Figure 4.73 [70] Shows A, B) Scan along the surface with the positions of the minimum of the as cast demo-axial; C) Ultrasonic raw data of third step of $360^{\circ}$ scan
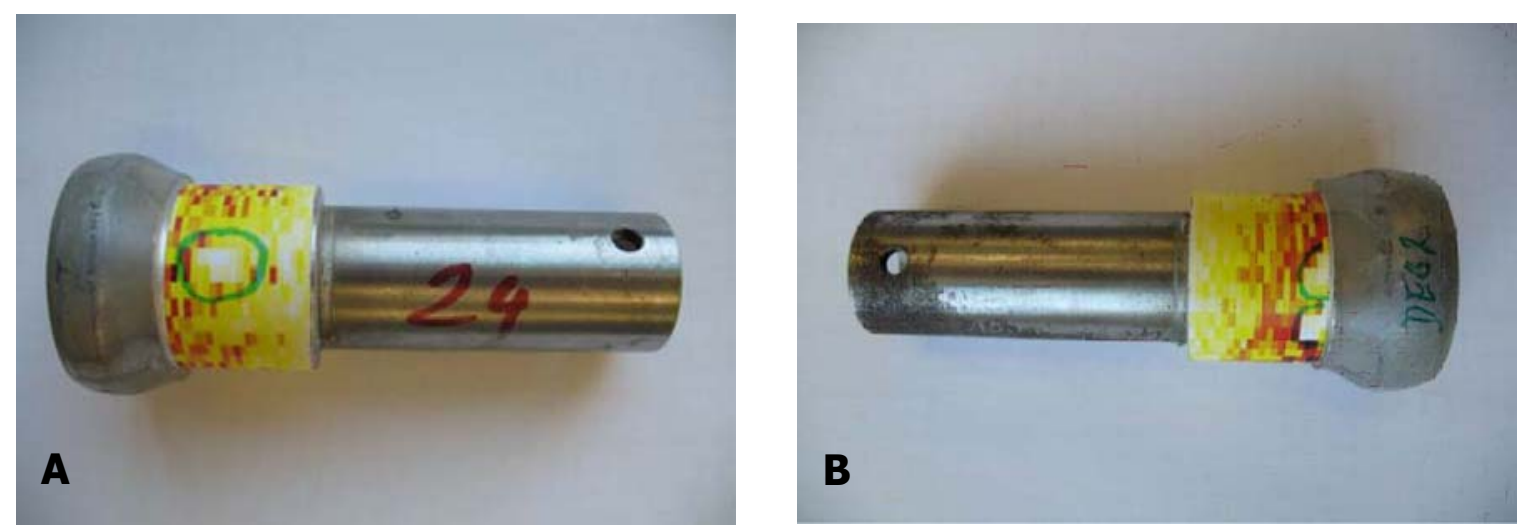

Figure 4.74 LUS Maximum marked A) Right tube section of demo-axial sample after heat treatment of $\left.165^{\circ} \mathrm{C} / 2.5 \mathrm{~h}, \mathrm{~B}\right)$ Left tube section of demo-axial sample after heat treatment of $165^{\circ} \mathrm{C} / 2.5 \mathrm{~h}$

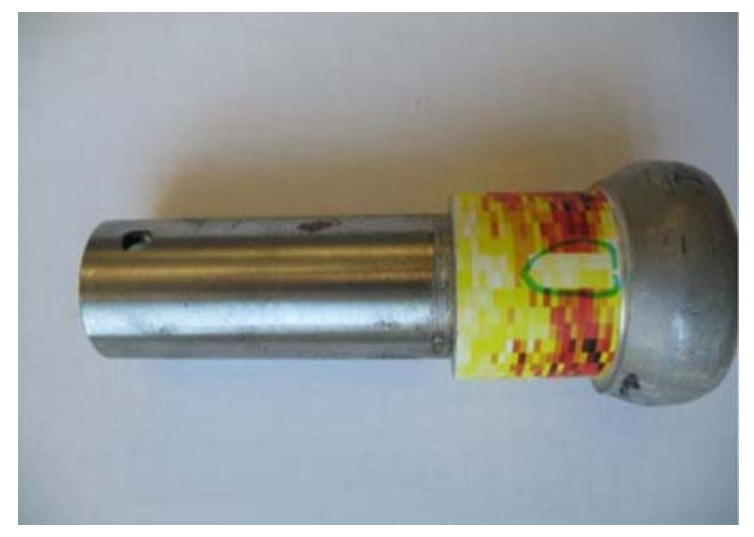

Figure 4.75 Left tube section of the demo-axial sample at as cast condition (the right one didn't show any defect) 


\section{Chapter 5}

\section{Discussion of the results}

\subsection{Cast microstructure}

Figure 5.1 shows different bulk microstructures of the different casting processes of AlSi7 and AlSi7Mg0.3. The dendrite arm spacing of AlSi7Mg are changing from $12 \mu \mathrm{m}$ in the fine structured regions in $D$ to almost $100 \mu \mathrm{m}$ in $\mathrm{C}$ of low pressure die casting. In case of AlSi7 alloy, the SDA are of about $34 \mu \mathrm{m}$ (position A). Some porosity is observed as well. In the microstructure of the squeeze cast sample (D) a bimodal SDA distribution is observed.
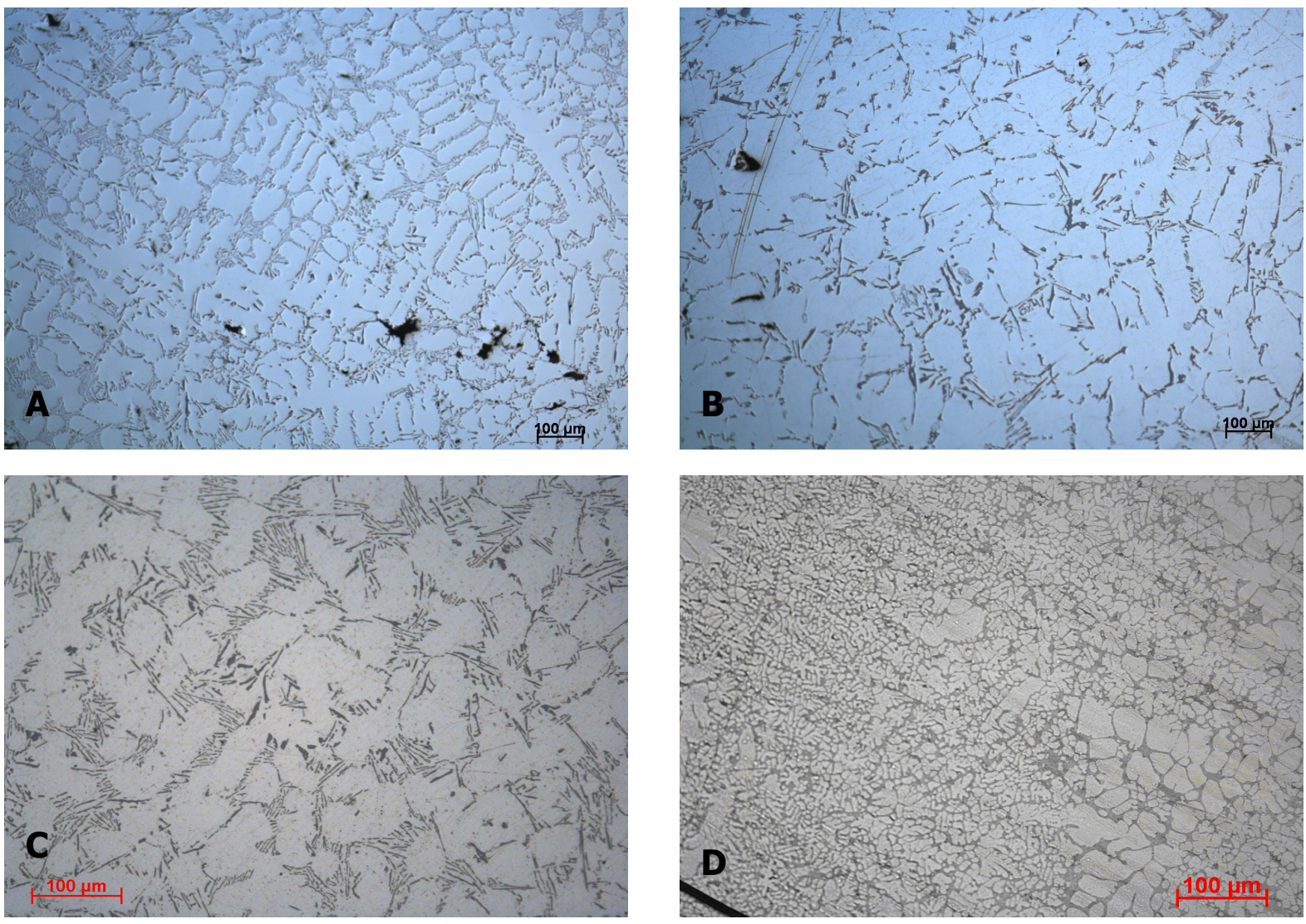

Figure 5.1 Microstructure of the bulk of A) gravity die casting of AISi7 rod sample, B) gravity die casting of AlSi7Mg0.3 cube sample, C) low pressure die casting of AlSi7Mg0.3 step sample and

D) squeeze casting of AlSi7Mg0.3 demo-axial sample

The aluminium casting consists mainly of $\alpha$-dendrites and the lamellar Al-Si12 eutectic in the interdendritic regions. Mg additions allow precipitation hardening of the a-Al [4]. The different secondary dendrite arm spacings (SDA) reflect the local cooling rate in the mould. Close to the mould, the SDA are much smaller, which means that solidification started from the cold mould. 
Bimodal structures, which have been observed in demo-axial samples are shown in Figure 4.21-4.23. The structure shows dendrite distributions with separated regions of eutectic in between. In Figure $4.23 \mathrm{~A}$ we can observe three different areas: with $\alpha$-dendrites of about $30 \mu \mathrm{m}$, with dendrites of about $50 \mu \mathrm{m}$. Both regions are separated by huge eutectic. The primary a-Al solidifies at first, then hotter melt is pressed in between mixing with the present melt resulting in a huger $\mathrm{Si}$ concentration, where afterwards the smaller secondary dendrite arm spacing solidifies. In Figure 4.23 E we can observe dendrites (marked by red arrows), broken by the pressure from the casting process.

The pressed in $\mathrm{Si}$ enriched melt solidifies last producing the larger eutectic regions.

Because the AISi7Mg alloy belongs to the hypoeutectic alloys, those aluminium alloys begin with dendritic growth of a-Al primary solid phase and Al-Si eutectic solidified last in between the dendrite arms. In some cases, a second solidification front starts from the cold insert. If solidification started at the interface (in a hot mould) embedding fails due to heat transfer to the insert, remelting and a second solidification path from the mould causes significant porosity.

The micrographs (Figure 4.33) show that there is evidence of interdendritic shrinkage porosity at the interface of the step sample. Shrinkage strains develop not only around the steel insert, but as well in longitudinal direction causing plastification and occasionally cracking.

Gaps occur around the insert in most of the samples, caused by gas entrapment. At the bonded interface we can observe eutectic zones. The shape of the gaps in Figure 5.2 indicates that they were formed during solidification probably owing to gas entrapment unlike mechanically induced debonding.

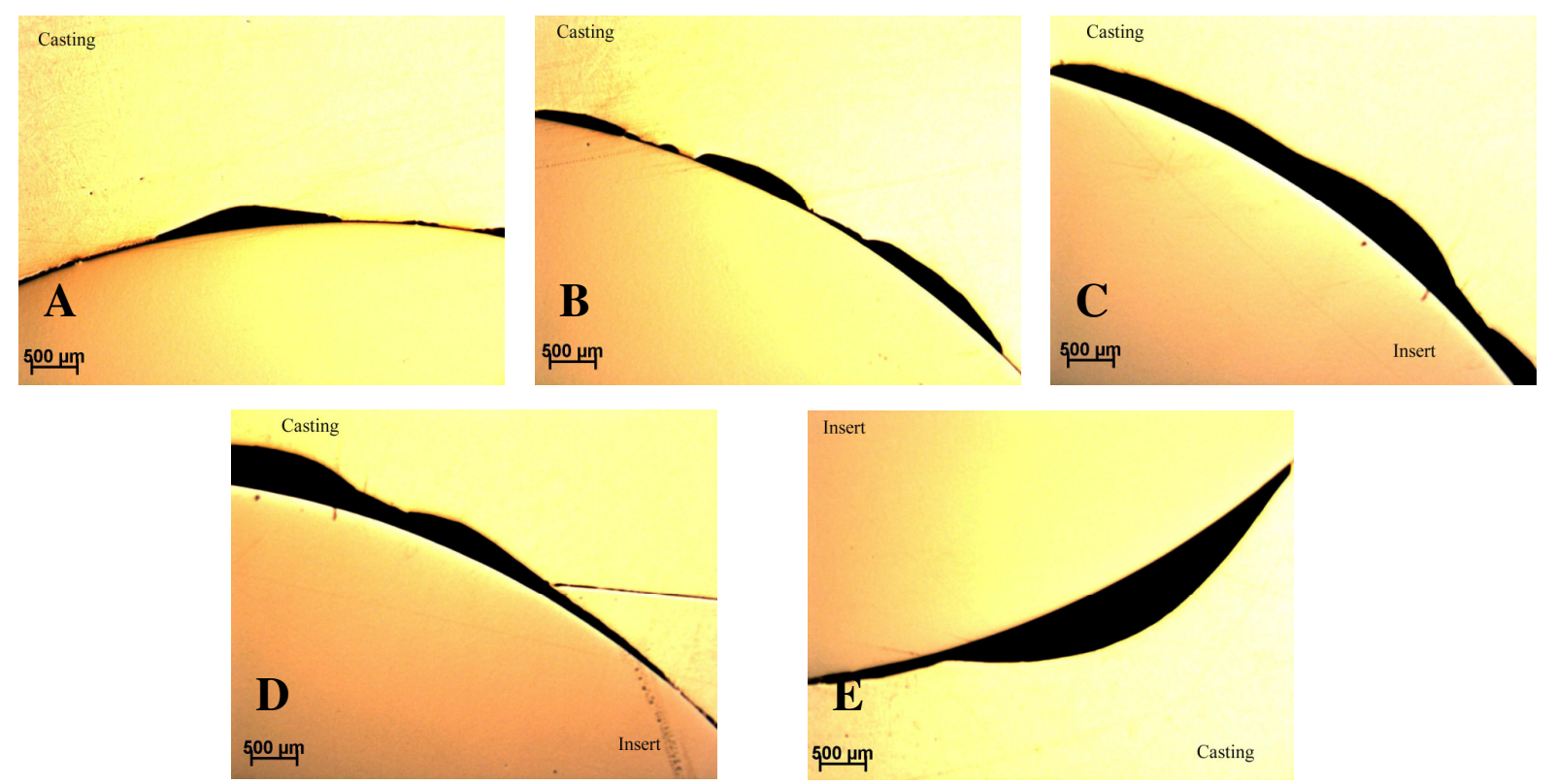

Figure 5.2 Optical Micrographs of the middle plane of step sample with local gaps 
Looking in Figure 4.25 R (rods sample) we can see the corners of the groove were not fully filled by the AlSi7 alloy due the shrinkage of aluminium. The relative shrinkage along the steel insert in the step sample should amount to about $0.1 \mathrm{~mm}$ according to the mismatch of the coefficient of thermal expansion, which

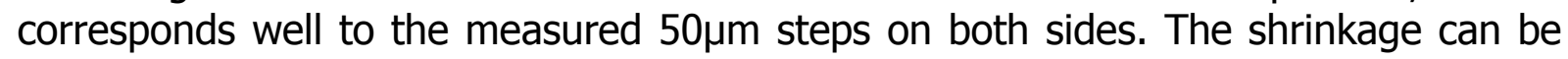
observed already less than $2 \mathrm{~mm}$ from the border of the insert. Figure 4.29 shows a sketch of the overflow of Al over the steel insert.

Light optical micrographs of the step sample (Figure 4.31) show that an overflow of Al appears on both sides, where a shrinkage of the aluminium casting of about $0.1 \mathrm{~mm}$. The thermal mismatch for a temperature change $550 \mathrm{~K}$ produces a relative shrinkage of Al with respect to steel $0.8 \%$ was estimated meaning that it was sliding along the cylindrical surface of the steel insert.

$$
\begin{aligned}
\varepsilon(\Delta T) & =\Delta C T E * \Delta T=15.10^{-6} * 100=0,15 \% \text { per } 100^{\circ} \mathrm{C} \\
& + \text { solidification shrinkage } \Rightarrow>\mathbf{0 . 1} \mathbf{m m} \text { gap }
\end{aligned}
$$

According to the calculation of the shrinkage step along insert of step sample, the average shrinkage between Al bulk and the overflow rim is about $50 \mu \mathrm{m}$.

There is evidence of shrinkage pores, gaps around the steel inserts. Figure $4.44 \mathrm{~A}, \mathrm{~B}$ shows no bonding between the steel insert and the AlSi7Mg casting in cube sample. It is assumed that the melt solidified fast (without reaction) at the steel surface. The insert embedded in aluminium caused at first solidification around the insert which got heated by the melt. The solidified 'coat' was pulled away by the shrinkage of the later solidifying surrounding AISi7Mg. This caused the formation of the cracks in the corners and of the gap between insert and casting as indicated in Figure 5.3. Such big gaps can be produced by the solidification shrinkage not compensated by melt filling. A cube of $10^{6} \mathrm{~mm}^{3}$ shrinking by 6 vol.\% would produce a hole of $6 \cdot 10^{4} \mathrm{~mm}^{3}$ (40mm in diameter). The hole in sample 3 (Figure $4.44 \mathrm{D}$ ) measures $>10^{3} \mathrm{~mm}^{3}$ indicating that the outer shape shrank as well.
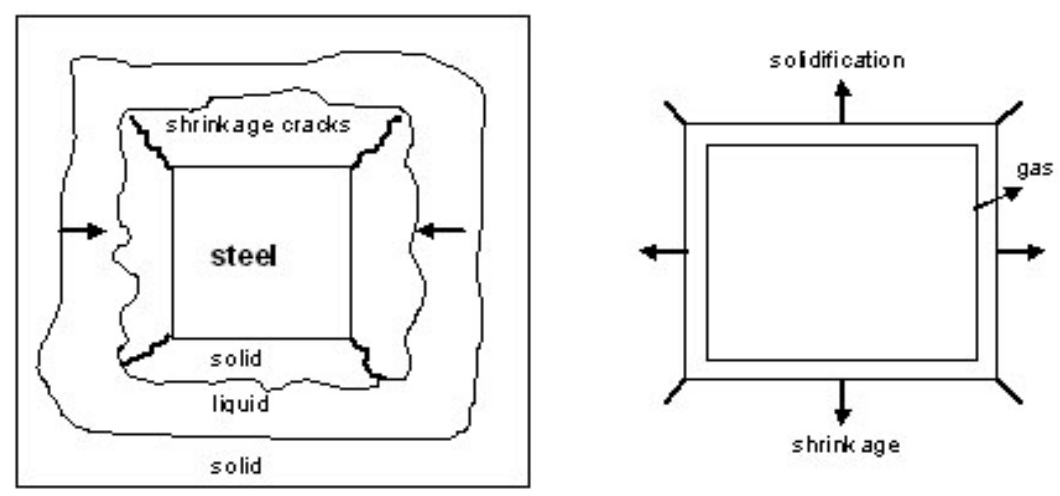

Figure 5.3 Sketch of the gravity cube cast sample showing shrinkage cracks formed on the Al side 
Al-casting of cube sample (hot mould) did not embed the steel insert. A big shrinkage hole surrounded most of the steel insert (Figure 4.44 C, D). Cube sample 3 (hot mould, Figure 4.43) showed good embedding of the steel insert. The AlSi7Mg casting exhibits high micro-porosity around the insert.

Interface reaction took place at the faces of contact between steel and Al-melt, when, cracks are produced parallel to the interface, a few $\mu \mathrm{m}$ within the reaction zone of the steel. The Fe-aluminides grow columnar into the steel insert. Islands of Al-Fe-Si phases were identified on the steel insert of sample 3. Similar islands of interface reaction have been observed in the rod samples.

The steel insert of the sample cast into the cold mould was completely embedded into the Al casting (Figure 4.40). The interface reaction zone is somewhat narrower than in sample 1 indicating shorter contact time between molten Al and steel.

The Al-side of the interface was enriched in $\mathrm{Fe}$ (in liquid state) forming Fe-aluminides during solidification. Cracks parallel to the interface are observed within the reaction zone in the steel insert as well as in the Fe-aluminide enriched Al-casting (ca. 50 $\mu \mathrm{m}$ ). This indicates that there was close contact between Al-melt and steel. Probably the cracks within Al formed before those in the reaction zone, because of the temperature gradient produced by the cold mould. The results of metallography chapter can be summarized in Table 5.4.

Table 5.4 Summarized information of the metallography part of the investigated samples

\begin{tabular}{|c|c|c|c|c|c|}
\hline & $\begin{array}{c}\text { Rods sample } \\
\text { AISi7 }\end{array}$ & $\begin{array}{c}\text { Cube sample } \\
\text { (pure Al) }\end{array}$ & $\begin{array}{c}\text { Cube sample } \\
\text { (AISi7Mg) }\end{array}$ & $\begin{array}{l}\text { Step sample } \\
\text { AISi7Mg0.3 }\end{array}$ & $\begin{array}{c}\text { Demo-axial } \\
\text { sample } \\
\text { AISi7Mg0.3 }\end{array}$ \\
\hline Casting & $\begin{array}{l}\text { Gravity die } \\
\text { casting }\end{array}$ & $\begin{array}{l}\text { Gravity die } \\
\text { casting }\end{array}$ & $\begin{array}{l}\text { Gravity die } \\
\text { casting }\end{array}$ & $\begin{array}{l}\text { Low pressure } \\
\text { die casting }\end{array}$ & $\begin{array}{c}\text { Squeeze } \\
\text { casting }\end{array}$ \\
\hline Steel & $\begin{array}{c}\text { St } 37,18-8 \\
\text { CrNi, } \\
\text { clean steel } \\
\text { (melt: } 700^{\circ} \mathrm{C} \text {, } \\
750^{\circ} \mathrm{C} \text { ) and } \\
\text { oxide (melt at } \\
700^{\circ} \mathrm{C} \text { ) }\end{array}$ & $\begin{array}{l}\text { St } 37 \\
\text { mould: } \mathrm{RT} \text {, } \\
700^{\circ} \mathrm{C}\end{array}$ & $\begin{array}{l}\text { St } 37 \text { - surface } \\
\text { etched } \\
\text { CrNi - surface } \\
\text { etched } \\
\text { mould: RT, } \\
700^{\circ} \mathrm{C}\end{array}$ & $\begin{array}{l}\text { St } 52 \text { without } \\
\text { surface } \\
\text { coating }\end{array}$ & C45E \\
\hline SDA [ $\mu \mathrm{m}]$ & SDA: 5-75 $\mu \mathrm{m}$ & $\begin{array}{l}\text { SDA: } 20-100 \\
\mu \mathrm{m}\end{array}$ & $\begin{array}{l}\text { SDA: } 20-30 \\
\mu \mathrm{m}\end{array}$ & SDA: $5-25 \mu \mathrm{m}$ & $\begin{array}{c}\text { SDA: } 8-20 \mu \mathrm{m} \\
50-80 \mu \mathrm{m} \\
\end{array}$ \\
\hline $\begin{array}{l}\text { Solidification } \\
\text { starts at }\end{array}$ & $\begin{array}{l}\text { Solidification } \\
\text { starts from the } \\
\text { insert }\end{array}$ & $\begin{array}{l}\text { Mould at } \\
700^{\circ} \mathrm{C}: \\
\text { solidification } \\
\text { starts from the } \\
\text { insert; } \\
\text { Mould at RT: } \\
\text { solidification } \\
\text { starts from the } \\
\text { mould }\end{array}$ & $\begin{array}{l}\text { Mould at } \\
700^{\circ} \mathrm{C} \text { : } \\
\text { solidification } \\
\text { starts from the } \\
\text { insert; } \\
\text { Mould at RT: } \\
\text { solidification } \\
\text { starts from the } \\
\text { mould }\end{array}$ & $\begin{array}{l}\text { Solidification } \\
\text { starts from the } \\
\text { mould }\end{array}$ & $\begin{array}{l}\text { Solidification } \\
\text { starts from the } \\
\text { insert }\end{array}$ \\
\hline
\end{tabular}




\begin{tabular}{|c|c|c|c|c|c|}
\hline $\begin{array}{l}\text { Interface } \\
\text { reactions }\end{array}$ & $\begin{array}{l}\text { Intermetallic } \\
\text { islands on } \\
\text { cleaned steel } \\
5-115 \mu \mathrm{m}\end{array}$ & $\begin{array}{l}\text { Intermetallic } \\
\text { phases } 15-19 \\
\mu \mathrm{m}(\text { mould } \\
\left.700^{\circ} \mathrm{C}\right)\end{array}$ & $\begin{array}{l}\text { Intermetallic } \\
\text { islands on } \\
\text { both sides } 80 \text { - } \\
300 \mu \mathrm{m}\end{array}$ & $\begin{array}{l}\text { No interface } \\
\text { reactions }\end{array}$ & $\begin{array}{l}\text { No interface } \\
\text { reactions }\end{array}$ \\
\hline $\begin{array}{l}\text { Gaps, } \\
\text { cracks, } \\
\text { porosity }\end{array}$ & $\begin{array}{l}\text { - cracks } \\
\text { - porosity }\end{array}$ & $\begin{array}{l}\text { - mould at } \\
700^{\circ} \mathrm{C} \text { did not } \\
\text { embed the } \\
\text { steel insert } \\
\text { - cracks } \\
\text { - porosity }\end{array}$ & $\begin{array}{l}\text { - porosity } \\
\text { much bigger } \\
\text { than in pure Al }\end{array}$ & $\begin{array}{l}\text { - gaps around } \\
\text { the insert } \\
\text { - small } \\
\text { porosity }\end{array}$ & $\begin{array}{l}\text {-gaps in the } \\
\text { bulk of the } \\
\text { casting } \\
\text { - small } \\
\text { porosity }\end{array}$ \\
\hline
\end{tabular}

The experimental results of LUS showed that using ultrasound helps to identify defects of the interface between steel and aluminium. Non destructive testing by Laser Ultrasonic is very helpful to investigate the interface quality within in the bulk of material of the position of the defects which can be confirmed by LOM or SEM (Figure 4.24).

\subsection{Dendrite structure in function of cooling rate}

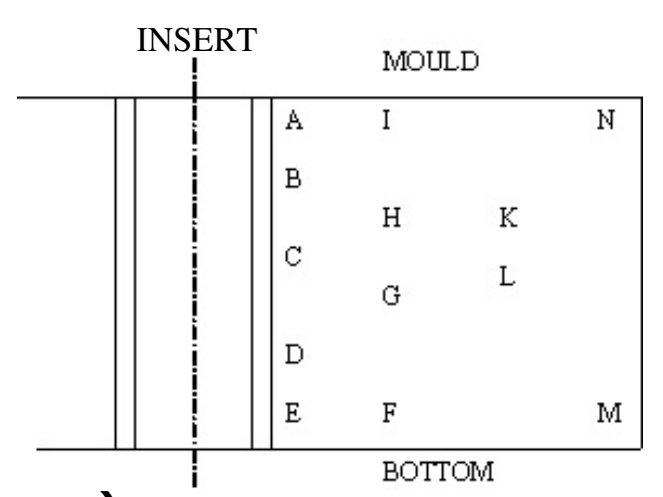

a)

b)

\begin{tabular}{|l|c|c|c|}
\hline & $\begin{array}{c}\text { SDA } \\
\mathbf{\mu m}\end{array}$ & $\begin{array}{c}\text { Measured } \\
\text { solidification } \\
\text { rate K/s }\end{array}$ & $\begin{array}{c}\text { SDA } \\
\mathbf{\mu m} \\
\text { [Kaufman] }\end{array}$ \\
\hline $\mathrm{A}$ & $<3$ & $>50$ & $3-5$ \\
\hline $\mathrm{B}$ & $\sim 10$ & 20 & 13 \\
\hline $\mathrm{C}$ & $<3$ & $>50$ & $3-5$ \\
\hline $\mathrm{D}$ & $\sim 15$ & $5-10$ & $15-20$ \\
\hline $\mathrm{E}$ & $\sim 20$ & $5-10$ & $15-20$ \\
\hline $\mathrm{F}$ & $\sim 20$ & $>20$ & 13 \\
\hline $\mathrm{G}$ & $\sim 10$ & $>15$ & $15-16$ \\
\hline $\mathrm{H}$ & $\sim 10$ & $>15$ & $15-16$ \\
\hline $\mathrm{I}$ & $\sim 10$ & $10-20$ & $13-16$ \\
\hline $\mathrm{K}$ & $10-15$ & $20-40$ & $13-10$ \\
\hline $\mathrm{L}$ & $10-15$ & $20-40$ & $13-10$ \\
\hline $\mathrm{M}$ & $<15$ & $20-40$ & $13-10$ \\
\hline $\mathrm{N}$ & 10 & $20-40$ & $13-10$ \\
\hline
\end{tabular}

Figure 5.5 a) Sketch of a cross section of the step sample, b) Table of SDA and solidification rate of the step sample with the positions indicated in sketch A with the SDA according to the cooling rate according to Kaufman [10] 
Table 5.6 Measured SDA [ $\mu \mathrm{m}]$

\begin{tabular}{|l|c|c|c|c|c|}
\hline \multicolumn{1}{|c|}{ Sample } & Interface & Bulk & Mould & $\begin{array}{c}\text { Gas } \\
\text { entrapment }\end{array}$ & $\begin{array}{c}\text { Shrinkage } \\
\text { pores }\end{array}$ \\
\hline $\begin{array}{l}\text { Rod } \\
\text { sample }\end{array}$ & $29-97$ & $5-75$ & $44-75$ & no & yes \\
\hline $\begin{array}{l}\text { Cube } \\
\text { sample }\end{array}$ & $40-60$ & $100-300$ & $40-50$ & no & yes \\
\hline $\begin{array}{l}\text { Step } \\
\text { sample }\end{array}$ & $<3-20$ & $8-20$ & $12-20$ & yes & yes \\
\hline $\begin{array}{l}\text { Demo-axial } \\
\text { sample }\end{array}$ & $35-40$ & $10-52$ & $30-50$ & no & yes \\
\hline
\end{tabular}

\subsection{Embedding strength}

During solidification Al-alloys shrink by about 6 vol.\%, but the yield strength is so low just below the solidification temperature that plastic deformation will occur around an insert. The linear coefficient of thermal expansion (CTE) of Fe is roughly half of that of $\mathrm{Al}(\Delta \mathrm{CTE}>12 \mathrm{ppm} / \mathrm{K})$. Assuming that thermally induced elastic stresses can build up below $300^{\circ} \mathrm{C}$, the misfit volume between $\mathrm{Fe}$ and $\mathrm{Al}$ amounts to about $1 \mathrm{vol} . \%$. Assuming that the iron insert is tightly embedded into the Al alloy after casting, the shrinkage difference accumulating during cooling causes elastic and plastic straining of the Al alloy surrounding the insert. The elastic stresses building up depend on the yield strength of the alloy. The elastic straining of the Al is higher than that of the steel insert owing to the modulus difference.

The shrink fit strength depends on the micro-structure of the Al-casting. The room temperature yield strength of pure Al is around $50 \mathrm{MPa}$, that of the AlSi12 eutectic around $150 \mathrm{MPa}$. Both increase after precipitation hardening to about 150 and $>200 \mathrm{MPa}$ respectively. Thus a linear deformation of $0.36 \%$ causes different degrees of plastic deformation within the phases of the Al alloy equilibrating the stress around the insert: max elastic straining of $\mathrm{Al} 7 \cdot 10^{-4}$ before aging and $2 \cdot 10^{-3}$ in the eutectic, to which the Al comes close after aging.

The temperature dependence of the yield strength of AlSi7Mg0.3 approximated by the strength of $2 \%$ true strain decreases linearly from about $180 \mathrm{MPa}$ at $120^{\circ} \mathrm{C}$ to about $20 \mathrm{MPa}$ at $500^{\circ} \mathrm{C}$. The corresponding dates for pure Al are presented for comparison in Figure 5.7. 


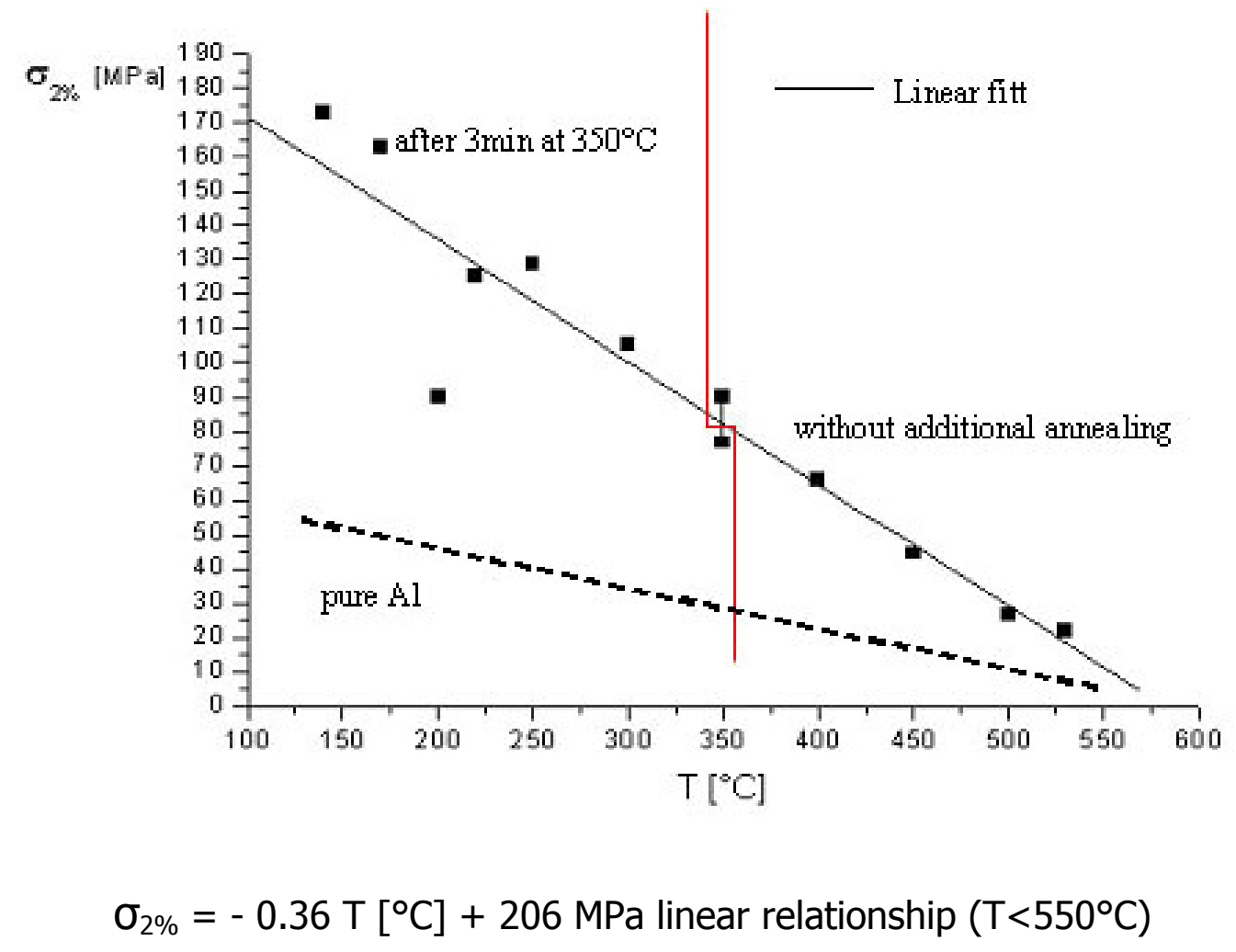

Figure 5.7 Graph showing the stress at 0.02 true strain changing with the temperature of AISi7Mg and pure Al

The Al-Si system is a simple eutectic system contains two phases, fcc Al with a coordination number of 12 and diamond cubic Si with a coordination number of 4 [16], referred to the Hume-Rothery rules for substitutional solid solution the solubility of $\mathrm{Al}$ and $\mathrm{Si}$ is extremely limited [71]. The solubility of silicon in aluminium reaches a maximum 1.65 at. \% at the eutectic temperature of $577^{\circ} \mathrm{C}$ (see Figure 2.5).

Figure 4.52 shows the comparison of changing lengths of AlSi7Mg0.3 and pure $\mathrm{Al}$ during heating after solution quenching from different temperatures with some calculation below according to the solubility changes.

The thermal condition changes considerably the hardness of the AlSi7Mg0.3 alloy after heating up to $350^{\circ} \mathrm{C}$ (see Figure 4.48). After heating the alloy by $50 \mathrm{~K} / \mathrm{min}$ up to $540^{\circ} \mathrm{C}$, the hardness of the material decreases.

The hardness measurements showed quite similar results after different thermal treatments. Brinell hardness of as cast sample of AlSi7Mg0.3 heated up to $250^{\circ} \mathrm{C}$ with heating rate of $10 \mathrm{~K} / \mathrm{s}$ is lower than after using heating and cooling rate of $50 \mathrm{~K} / \mathrm{s}$ (see Figure 4.45 and 4.48 ).

Figure 4.48 shows the comparison of hardness values of specimens in as cast condition, before DSC experiments and after DSC cycle which means solutions treated by heating up to $540^{\circ} \mathrm{C}$ with heating rate of $10 \mathrm{~K} / \mathrm{min}$ and cooling rate of $20 \mathrm{~K} / \mathrm{min}$. The lowest hardness value shows after the DSC cycles. 
Micro-hardness measurements show small differences of hardness values positioned on the eutectic of the as cast and after heat treatment $\left(350^{\circ} \mathrm{C} / 2 \mathrm{~h}\right)$ demo-axial sample.

The comparison of the DSC curves is shown in Figure 4.59. As shown in the figure, the two different kinds of samples have different peak temperatures. An exothermic peak of demo-axial sample starts at $240^{\circ} \mathrm{C}$. That peak in the as cast step samples starts at $250^{\circ} \mathrm{C}$. There is no such peak of the step sample after being heated up to $250^{\circ} \mathrm{C}$.

The residual stress in the Al dendrites and the interdendritic eutectic are limited by the strain hardening of the Al-matrix in the as quenched condition, which is assumed to yield strength less than $100 \mathrm{MPa}$ corresponding to about $0.1 \%$ elastic strain. After aging the yield strength increases to about $150 \mathrm{MPa}$ increasing the elastic strain after cooling correspondingly. Cooling from $250^{\circ} \mathrm{C}$ aging temperatures produces less than $0.3 \%$ mismatch strain, at least $1 / 2$ of which cause residual stresses. The interface stresses during cooling are unevenly distributed shear stresses parallel to the interface.

Figure 4.63 shows the stress analysis of the investigated Al casting after quenching from $350^{\circ} \mathrm{C}$. Compressive stresses evolve in the Al of the Al-Si casting with increasing quenching temperature even without steel insert. The thermal mismatch between the Al and Si-phase causes thermal misfit stresses as shown in Figure 4.64. Only the region close to the interface to the steel insert shows tangential tensile stresses in Figure 4.63, resulting from adding ca $110 \mathrm{MPa}$ to the level of $-90 \mathrm{MPa}$ initial compressive stresses in Al. The tangential stresses around the insert could not be measured reliably (>30MPa tensile). There is a compressive stress background ( -90 $\mathrm{MPa}$ ) within the AlSi7 alloys due the expansion mismatch between Al and $\mathrm{Si}(\Delta \mathrm{CTE}$ $>20 \mathrm{ppm} / \mathrm{K}$ ). On top of that circumferential tensile stresses are superimposed. 


\section{Chapter 6}

\section{Conclusions}

Aluminium alloys possess a number of very attractive characteristics which together with their very light weight make them extremely attractive for many applications. Aluminium alloys are up to the task, and that no matter what your needs may be there is probably a ready-made aluminium alloy to do the job [3].

- The AlSi7 castings consist of $\alpha$-dendrites and eutectic Al-Si in between. The secondary dendrite arm spacing varies between $5-75 \mu \mathrm{m}$ reflecting locally different solidification rates. Close to the cold mold, the SAD is much smaller which means that solidification started from the mold. At the interface to the steel insert an even finer dendrite structure is observed in some cases indicating faster solidification along a thin layer around a cold steel insert. There solidification fronts from the steel insert and from the mould proceed. The interface microstructure varies from 20 to 30 vol\% of AlSi12 eutectic, which indicates macrosegregations as $50 \%$ would result from an equilibrium.

- The cooling rate of the whole step casting varies from about $40 \mathrm{~K} / \mathrm{s}$ (next to the steel insert) to $160 \mathrm{~K} / \mathrm{s}$ in the Al section (near mould, $10 \mathrm{~mm}$ thick). The difference reflects the slower solidification rate at the steel interface than in the rest of the casting $(70 \mathrm{~K} / \mathrm{s})$. This can be explained by heating of the steel insert by the surrounding Al-melt. Solidification starts from the upper and lower surface of the casting. It changes as well along the interface with the insert. The local solidification rates vary within $10 \mathrm{~K} / \mathrm{s}$ and $>50 \mathrm{~K} / \mathrm{s}$ as deduced from the secondary dendrite arm spacing.

- Steel inserts in Al casting showed interface defects like shrinkage holes, gaps, porosity. The shrinkage wholes occur along the steel insert, where the alloy solidifies last or was remelted.

Frequently gas entrapment between steel and the Al melt (step sample) is formed. At the gas entrapment gaps, solidification of the Al casting progresses towards the insert (solidifies there at last). Such gaps are less frequent in the $10 \mathrm{~mm}$ thick region.

- Interface reactions took place during contact of the oxide free steel with the Al melt, significantly more with pure Al than with the Al-Si alloys. Those interface layers of aluminides are not only formed on the steel, but as well within the adjacent aluminium. The mechanical bonding seems better if the interface reaction took place at separated spots. 
- The residual stress in Al-Si alloy cause significant compressive stress of $70 \pm 20 \mathrm{MPa}$ in a-Al after reheating and quenching due to the thermal mismatch with Si. Shrinkage of Al with respect to the steel insert is observed at least $2 \mathrm{~mm}$ from the insert interface. Circumferential tensile stresses are superimposed close $(<2 \mathrm{~mm})$ to the interface with the steel insert. The tangential stress increases towards the interface, where $40 \mathrm{MPa}$ tensions (stress changes from -70MPa to $+40 \mathrm{MPa}$ by about $110 \mathrm{MPa}$ ) are measured. The residual compressive stress in the radial direction amounts to $250 \pm 40 \mathrm{MPa}$.

- The yield strength of AlSiMg decreases linearly from around $180 \mathrm{MPa}$ at $110^{\circ} \mathrm{C}$ to about $20 \mathrm{MPa}$ at $500^{\circ} \mathrm{C}$. Elastic stresses may build up during cooling only the last $200^{\circ} \mathrm{C}$ (yield strength ca. $130 \mathrm{MPa}$ at $250^{\circ} \mathrm{C}$ ). The embedding strength seems to be provided by the surface roughness of the insert anchoring the insert. Age hardening of the AlSi7Mg alloy improves the bonding strength due the increase in yield strength (ca. 190MPa).

- Laser Ultrasound can be used for tubular inserts for non destructive testing of the interface quality, if it can be excited from the inside.

The quality of bonding of the steel insert in an Al-Si-cast alloy depends mainly on the embedding casting method. Solidification starting from the steel insert is desirable, but usually competes with the solidification front coming from the mould. Low pressure die casting produced interfaces with the least defects density.

Degrading effects from interface reactions could not be verified. Naturally oxidized steel inserts do not react within usual solidification periods. High bonding strength is achieved by interfaces interlocking at the machining groves of the steel insert in absence of casting defects. The contribution of the elastic shrink fitting provides additional bonding.

Steel inserts in Al are an estabilished technique, but if you look closer, you might reveal defects. 


\section{References}

1. E. Totten, D. Scott, Mackenzie Hand Book of Aluminium 1, 2003

2. D.G. Altenpohl, Aluminium: technology, Applications and Environment, 1998

3. Aluminium alloy, The Aluminium Association, 1998

4. I.J. Polmear, Light Alloys, Metallurgy of the Light Metals ( $3^{\text {th }}$ edition), 1995

5. The European Aluminium Association, www. eaa.net

6. K. Sears, Automotive engineering: Strategies Overview 2 (1), p. 55-68, 1997

7. W.S. Miller, L. Zhuang, J. Bottema, A.J. Witterbrood, P. De Smet, A. Haszler, Recent development in aluminium alloys for the automotive industry, Materials Science and Engineering A280, p. 3749,2000

8. E. Paul, DeGarmo, J.T. Black, Kohser, A. Ronal (2003). Materials and Processes in Manufacturing ( $9^{\text {th }}$ edition). Wiley. p. 133

9. S.F. Pollard, Boatbuilding with aluminium, International Marine 1993

10. J.G. Kaufman, E.L. Rooy, Aluminium alloys castings: Properties, Processes and Applications, 2005

11. http://www.word-aluminium.org

12. G. Cole, A. Glove, R. Jeryan, G. Davies, Steel World 2 (1), p. 75-83, 1997

13. J. Wiley, Materials processing during casting, England 2006

14. S. Murali, K.S. Raman, K.S.S Murthy, Effect of magnesium, iron and solidification rates on the fracture toughness of AlSi7Mg0.3 casting alloy, Material Science Engineering 151, p. 1-10, 1992

15. L.F. Mondolfo, Aluminium alloys: structure and properties, 1979

16. J.L. Murray, A.J. McAlister, Vol.8, Metals Handbook ( $8^{\text {th }}$ edition), p. 263, 1973

17. R.J. Davis, Aluminium and Aluminium alloys, ASM Specialty Book, 1994

18. R. A. Flinn, Fundamentals of Metal Casting, 1, 1963

19. W.E. Sicha, Properties of commercial casting alloys, Aluminium Vol.1- Properties, Physical Metallurgy and Phase Diagram, 4 American Society Metals, p. 277-302, 1971

20. F.A. Lasagni, Dissertation, Technische Universität Wien, 2006

21. A.K. Dahle, Heat treatment of aluminium alloys, encyclopedia of Materials Science and Technology 3, p. 1-3, 2001

22. M. Meier, Department of Chemical Engineering and Materials Science, 2004 
23. G.A. Edwards, K. Stiller, G.L. Dunlop, M.J. Couper, The precipitation sequence in Al-Mg-Si alloy, Acta Materialia 46 (11) p. 3893-3904, 1998

24. K. Matsuba, Y. Sakaguchi, Y. Miyata, Y. Uteni, T. Sato, A. Kamilo, S. Ikeno, Metastable Phases in an Al-Si-Mg Alloy Containing Copper, Journal of Materials Science 35, p. 179-189, 2000

25. Heat treating, Metals Handbook ( $9^{\text {th }}$ edition), ASM International, Metals Park Vol.4, 1981

26. F.A. Lasagni, M. Dumont, C. Salamida, J.A. Acuna, H.P. Degischer, Dilatometry revealing Si precipitation in Al-Si-alloys, International Journal of Materials Research, Vol.100, 2009

27. F.A. Lasagni, H.R. Mohammadian, A. Falahati, H.P. Degischer, Volume change of Si-containing Alalloys during aging, 6th IFHTSE and 20th SMT Conference, Vienna 2006

28. F. Taghavi, S. Hasan, K. Yourself HK., Study on the effect of prolonged mechanical vibration on the grain refinement and density of A356 aluminium alloy, Material and Design 30 (5), p. $1604-1611,2009$

29. K.T. Chiang, N.M. Liu, T.C. Tstai, Modeling and analysis of the effects of processing parameters on the performance characteristics in the high pressure die casting process of Al-Si alloys, International Journal Advantaged Manufacturing Technology 41, p. 1076-1084, 2009

30. P.H. Fu, A.A. Luo, H.Y. Jiang, L.M. Peng, Y.D. Yu, C.Q. Zhai, Low pressure die casting of magnesium alloy AM50: response to process parameters, Journal Material Processing Technology 205 (1-3), p. 224-234, 2008

31. P.K. Seo, C.G. Kang, S,M. Lee, A study on reheating characteristic for thixio die casting process with electromagnetic stirring and extruded aluminium alloys, and their mechanical properties, International Journal Advantaged Manufacturing Technology 43 (5-6), p. 482-499, 2009

32. W. Young, Why die casting dies fail, $10^{\text {th }}$ SDCE, International Die Casting Exposition \& Congress, North American Die Casting Association, St. Louis, p. 1-7, Missouri 1979

33. A. Persson, S. Hogmark, J. Bergstrom, Surface and Coating Technology 191, p. 216-227, 2005

34. A.K. Dey, P. Poddar, K.K. Singh, K.L. Sahoo, Mechanical and wear properties of conventional gravity die cast A356 alloy, Materials Science and Engineering A 435-436, p. 521-529, 2006

35. W. Jiang, Z. Fan, D. Liao, D. Liu, Z. Zhao, X. Dong, Investigation of microstructure and mechanical properties of A356 aluminium alloy produced by expendable pattern shell casting process with vacuum and low pressure, Materials and Design 32, p. 926-934, 2011

36. M.R. Ghomashchi, A. Vikhrov, Squeeze casting: an overview, Journal of Materials Processing Technology 101, p. 1-9, 2000

37. G.A. Chadwick, T.M. Yue, Principles and applications of squeeze castings, Metallurgical and Materials 5 (1), p. 6-12, 1989

38. J.N. Pennington, Squeeze-cast parts approach performance of forgings, Mod. Met. 44 (1) 52, p. $54-60,1988$

39. O.G. Epanchistov, Structure and properties of metals solidified under high pressure, Russian Casting Production, p. 34-37, 1972

40. F. Shetata, Squeeze casting of Al-Cu and Al-Si alloys, Process. Adv. Mater 4 (3), p. $136-140,1994$ 
41. P. Balan, R.M. Pillai, K.G. Satyanarayana, B.C. Pai, The structure and properties of squeeze-cast eutectic Al-Si plates, International Journal Cast Metals Res. 6 (3), p. 131-136, 1993

42. M.R. Ghomashchi, K.N. Strafford, Factor influencing the production of high integrity Al-Si alloy components by die and squeeze casting process, Journal Material Processing Technology 38, p. 303-326, 1993

43. M. Noor, S. Jamaldian, K. Hussin, Microstructural study of Al-Si-Mg alloy reinforced with stainless steel wires composite via casting technique, American Journal of Applied Science 5 (6), p. 721725,2008

44. M. Merlin, G. Timelli, F. Bonollo, G. Garagnani, Impact behaviour of a356 alloy for low pressure die casting automotive wheels, Journal of Materials Processing Technology 209, p. $1060-1073,2009$

45. Q.T. Fang, D.A. Granger, Porosity formation in modified and unmodified A356 alloy castings, AFS Transaction, 97, p. 989-1000, 1989

46. R. Lumley, Fundamentals of aluminium metallurgy: Production, processing and applications, 2011

47. R. Cornell, H.K.D.H Bhadeshia, Aluminium-Silicon Castings Alloys, Set of lecture, University of Cambridge, 1995

48. K.J. Oswalt, M.S. Misra, Dendrite arm spacing (DAS): A nondestructive test to evaluate tensile properties of premium quality aluminium alloy (Al-Si-Mg) castings, AFS Transactions, 88, p. $845-862,1980$

49. H. Kaya, M. Gündüz, Dendritic growth in an aluminium-silicon alloy, ASM International, Vol.16, p. $12-21,2007$

50. M. Michael, H. Baker, Magnesium and Magnesium Alloys, ASM Specialty Handbook, 1999

51. Norsk Hydro Bulletin, Normaq; Magnesium, Pure and Alloys,

52. T.J. Ruden, Structural Design Trends for Magnesium Die Casting, International Symposium on Production, Refining and Fabrication of Light Metals, the Metallurgical Society of the Canadian Institute of Mining and Metallurgy, 1990

53. S. Housh, B. Mikucki, A. Stevenson, Selection and Application of Magnesium and Magnesium Alloys, Properties and Selection: Nonferrous Alloys and Special Purpose Materials, Vol.2, ASM Handbook, ASM International, p. 455-479, 1991

54. O. Kubaschewski, Iron-Binary Phase Diagrams, Springer-Verlag Berlin, 1982

55. G. Eggeler, W. Auer, H.Kaesche, On the influence of silicon on the growth of the alloy layer during hot dip aluminizing, Journal of Materials 21, 1986

56. R.D. Bitsche, U. Noster, C. Peterlechner, F.G. Rammerstorfer: Simulation von kraft- und formschlüssigen Hybridguss-Verbindungen als Designgrundlage, Tagungsbd. d 4. Ranshofener Leichtmetalltage, LKR-Verlag, Ranshofen, p. 275-286, 2006

57. R.D. Bitsche, Dissertation, Technische Universität Wien, 2009

58. W. Fragner, ARC Leichtmetallkompetenzzentrum Ranshofen $\mathrm{GmbH}$, Internal report 2007

59. SEW 310: Physikalische Eigenschaften von Stählen, Taschenbuch der Stahl-EisenWerkstoffblätter, 1992 
60. H.K.D.H Bhadeshia, Thermal analyses techniques. Differential thermal analysis, University of Cambridge, Material Science and Metallurgy 2002

61. H. Lehmann, Dilatometrie and differential thermal analysis for the evaluation of processes , 1956

62. K.P. Menard, Dynamic Mechanical Analysis, A Practical Introduction, Chapter 3, 1999

63. B. Wunderlich, Journal of Thermal Analysis and Calorimetry 78, 2004

64. $\underline{\text { www.hmi.de }}$

65. C.B. Scruby, L.E. Drain, Laser Ultrasonic: Techniques and applications, Adam Hilger, 1990

66. J.P. Monchalin, Optical Detection of Ultrasound, IEEE Transactions on Ultrasonic, Ferroelectrics and Frequency Control, Vol. UFFC-33, No.5, p. 485-499, 1986

67. X. Wang, X. Xu, Thermoelastic wave induced by pulsed laser heating; Applied Physics A 73, p. $107-114,2001$

68. M. Schöbel, Internal report, TU Wien 2007

69. M. Schöbel, Internal report, TU Wien 2008

70. B. Reitinger, RECENDT Research Center for Non Destructive Testing GmbH, Internal report 2010

71. H.R.M Semnani, Dissertation, Technische Universität Wien, 2006 


\section{CURRICULUM VITAE}

\section{PERSONAL INFORMATION}

Name and surname:

Address:

E-mail:

\section{EDUCATION}

III/2006

$\mathrm{XI} / 2003$

VI/2003

$\mathrm{X} / 1999$ - VI/2004

V/1998

IX/1994 - VI/1998

\section{ADDITIONAL COURSES}

X/2002 - IV/2003

IV/2008

\section{WORK EXPERIENCE}

XII/2003

II - III/2003
Karolina Zimnik

Steingasse 6 / 8

A-1030 Wien

kzimnik@pop.tuwien.ac.at

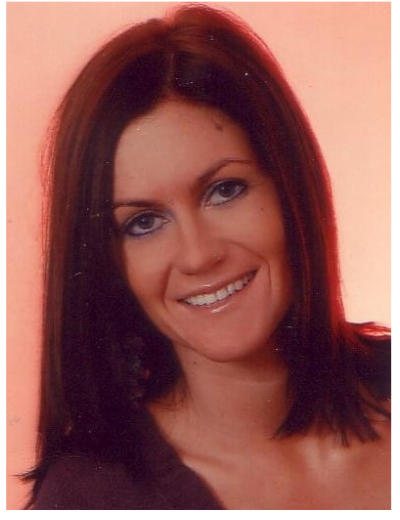

Vienna University of Technology, Vienna (Austria), Institute of Materials Science and Technology and $\mathrm{PhD}$ on Interface of steel inserts in Al-Si alloy castings

Vienna University of Technology, Vienna (Austria), TU Berlin, Berlin (Germany)

Institute of Materials Science and Technology and

Project studies on Microstructure and deformation behaviour of coronary stents during fatigue

Master thesis -

Biomechanical and clinical aspects of cervical spine implants

WROCLAW UNIVERSITY OF TECHNOLOGY, Wrocław (Poland)

FACULTY OF MECHANICS

Specialisation AUTOMATICS AND ROBOTICS

Maturity Exam

High School in Zgorzelec, (Poland)

AutoCad 2000 Polish LANGUAGE Edition - BASIC CoURSE

Course organised by the Wrocław University of Technology

Sample preparation, Vienna University of Technology, Vienna (Austria),

Research and development in DESY Deutsches ElektronenSynchrotron, Hamburg (Germany) and ESRF European Synchrotron Radiation Facility, Grenoble (France)

Wrocław University of Technology and MAGAL Speciality Orthopaedic Company, Wrocław (Poland)

(Upper extremity prosthesis project: architecture, mechanical design, drafts, Medical diagnosis hardware, MRI, X-ray, tomography) 

the flexion/extension compression load)

VII - VIII/2002

Factory of Surface Mining Machinery Joint Stock Company, FAMAGO S.A., Bogatynia (Poland)

(Speciality training - Automatics and Robotics)

\section{FOREIGN LANGUAGES}

- Polish (mother tongue)

- English (very good)

- German (good)

\section{LANGUAGE TRAINING}
I - II/2010
Deutsche Akademie, Vienna (Austria)
III - VI/2004
University of Vienna, Wiener Internationale Hochschulkurse
Vienna (Austria)

\section{$\underline{\text { ADDITIONAL ACTIVITIES }}$}

$X / 2002$

Member of Interdepartmental Students Organisation of Biomechanics, Wrocław University of Technology, Wrocław (Poland)

V/2003

Member of Polish Ergonomics Society

\section{QUALIFICATIONS}

- workgroup experience

- communication

- creativity

- flexibility

- organization

\section{$\underline{\text { INTERESTS }}$}

- medicine, medical equipment, prosthetic, implantology

- sport (ski, roller-skate)

- cinema, music, scientific \& fantasy novel

\section{$\underline{\text { OTHER }}$}

- driving licence (type A \& B)

- working knowledge of MS Office (Word and Excel)

- good knowledge of 2D/3D AutoCad drawing, Ansys scripting

- basic of Matlab software 